Historic, archived document

Do not assume content reflects current scientific knowledge, policies, or practices. 


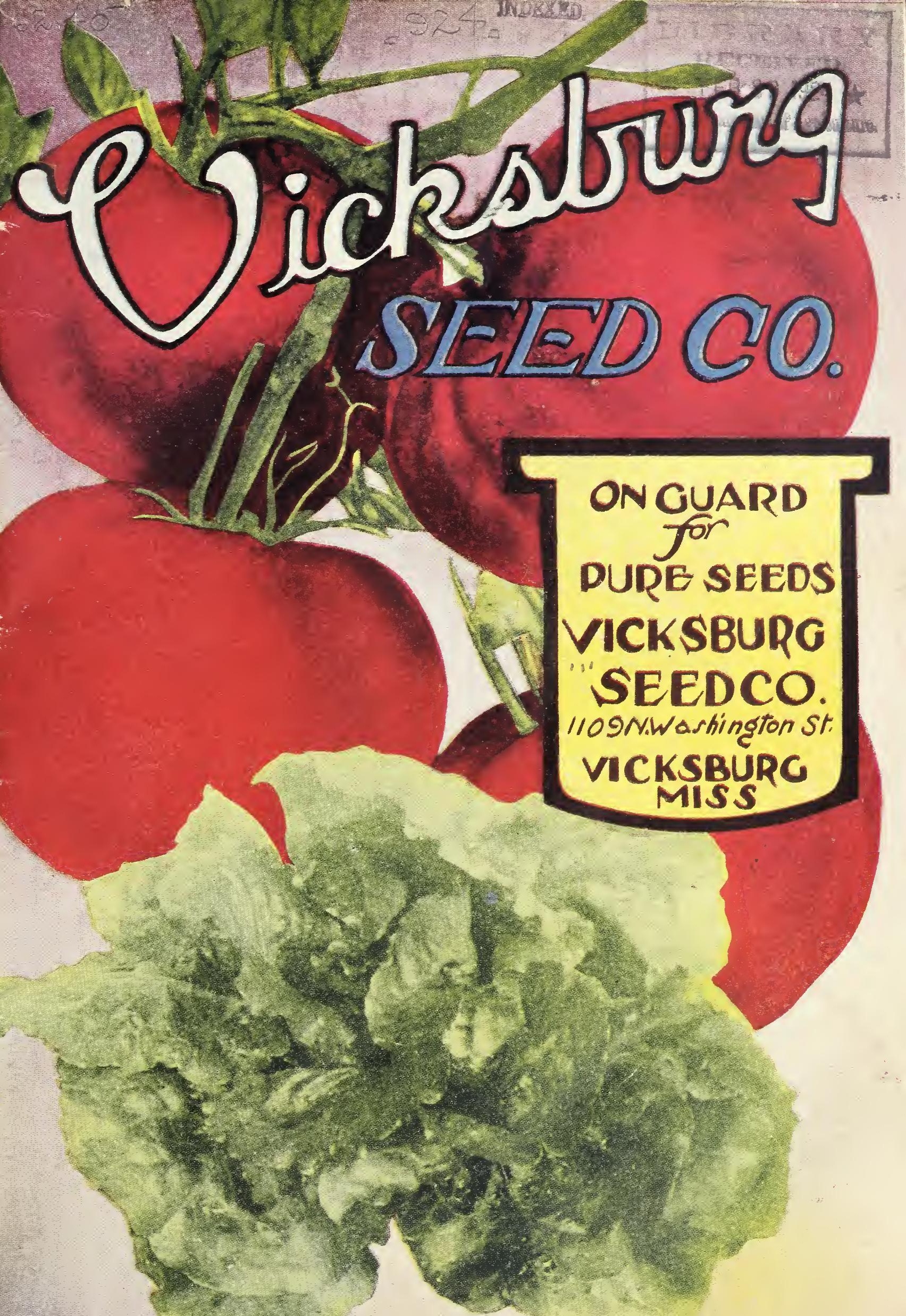




\section{Vicksburg Seed Company 1924 Catalog}

\section{TO OUR FRIENDS AND CUSTOMERS:}

The Vicksburg Seed Company is managed by men who have had many years of experience in all branches of the seed business and know the needs of our Southern farmers.

It is our policy to sell only quality seeds and you will find our prices right and our service as good as the best; all orders both large and small will be given our careful and prompt attention; all we ask is that you give us a trial, and we feel sure that you will become one of our friends and patrons.

\section{Sincerely yours,}

\section{VICKSBURG SEED CO.}

\section{J. F. HAID, President.}

\section{GENERAL INSTRUCTIONS TO CUSTOMERS}

PRICES AND TFRMS-The prices we quote on Vege table Seeds will hold good as long as stocks last. The prices on Grass Seeds, Grains and all Farm Seeds are those ruling January 1,1924 , and are subject to changes. As far as possible we will fill in full all orders for Seeds that are quoted subject to variation in price, but if market value will not permit this, we will send all that moner remitted will pay for.

Notice carefully the prices. Be sure to know whether we or you are to pay the carrying charges, and bear in mind that we do not pay the express or freight charges on pecks or bushels, nor on any Tools, Bulbs, Grass Seeds, Field Seeds or Fertilizers, except where we so state on the pages where the goods are priced.

Please Send Money With the Order sufficient to cover the whole bill, and remit by express money order or registered letter. Checks covering payment of goods must include 10 cents for collecting them. You will avoid delay by remitting by express or postoffice money order. We decline sending goods "Collect On Delivery" unless remittances be made on account to guarantee acceptance.

DEIIVERY GUARANTFFD-We will guarantee the safe arrival of all goods by Parcel Post. All packages lost will be replaced promptly and without cost to you.
NON-WARRANTY-The Vicksburg Seed Co. does not give, and their agents and employees are forbidden to give any warranty, express or implied, as to description, quality, productiveness, or any other matter of any seeds, bulbs, plants, etc., they send out and ther will not be in any way responsible for the crop. If the purchaser does not accept the goods on these terms, they are to be returned at once, and if the money has been paid for them, it will be refunded. NO RESPONSIBLF SEEDSMAN GIVES ANY WARRANTY.

POSTAGE-We pay postage on all Seeds quoted by the package, ounce, quarter-pound and pound, and upon all goods quoted in our catalog where it says parcel post paid.

MARKFT GARDENERS And Those Using Large Quantities of Seed should send us a list of their re quirements. Prices will be furnished promptly, and we can frequently make a substantial reduction on large orders.

FRRORS IN FIIIING ORDERS-While we exercise the greatest care in filling orders, mistakes sometimes oceur, in which event they will be cheerfully and promptly rectified by us. Keep a duplicate copy of all orders sent us until you have received the seed.

\section{N D E X}

\begin{tabular}{|c|c|c|}
\hline & & \\
\hline aragus Seed and Roots _----- & ruit Trees & h and Sweet - \\
\hline chokes ------------------ & ountains for Poultry & oultry Su \\
\hline------------------8 & eld Beans _- & oultry Food \\
\hline------------------3 & rmogerm ------ & D. \\
\hline ns, Bush and Pole _--_-_- 2- & $-\ldots-n--26-2$ & \\
\hline----------------3 & lies --------4 & and Roots \\
\hline Hives and Supplies _-_-_-_ 4 & -------------4 & 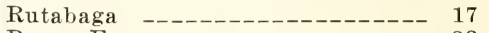 \\
\hline 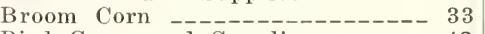 & 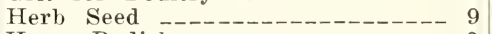 & \\
\hline Cages and Supplies _------ & & \\
\hline lers --------------------- & for Poultry _-_- & Sowers \\
\hline Flowering -------------- & $------------1-----$ & $\mathrm{ch}$ \\
\hline li & ------------------ & \\
\hline prouts --------------- & ------------------3 & \\
\hline ower -------------------- & ------------- & ed --------------- \\
\hline a Field Peas ------------ 3 & -------------6 & 皮 \\
\hline 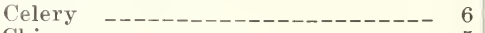 & Trass & \\
\hline$y \quad-----------------------$ & ------------- & 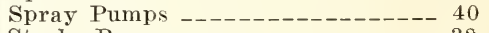 \\
\hline------------------------ & $\operatorname{try}---------47$ & (5) \\
\hline & ------- & \\
\hline oal for Poultry & 它 & \\
\hline ge ---------------------- & -31 & wer \\
\hline 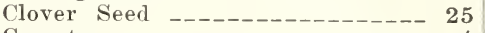 & 1 & Pea \\
\hline & & Plants_---_Inside I \\
\hline------------- & & \\
\hline d Field ---- 7.28-2 & & Chard \\
\hline----------------- , & $-\cdots----\cdots \overline{0}$ & \\
\hline & $----34-35-3$ & Beets \\
\hline 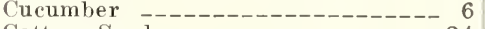 & s --- & S ---- \\
\hline & -------------- & \\
\hline 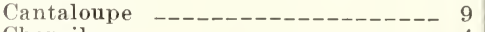 & & \\
\hline & Se & \\
\hline 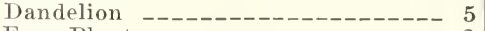 & Sh & ters \\
\hline 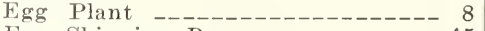 & e Grass Mixture _... & \\
\hline Shipping Boxes ----------- 45 & S - - - - - & rarde \\
\hline 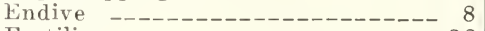 & & table Plants, Inside Back C \\
\hline 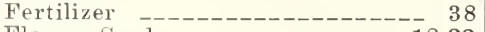 & & a ----------------------- \\
\hline----------- & & \\
\hline----------------4 & Peas, Gardeu & \\
\hline
\end{tabular}




\section{VICKSBURG SEED CO.}

Date

.1924

Enclosed find

State whether check, draft, money-order or stamps.

for $\$$.

in payment of order written below.

Name

Post Office.

R. F. D.

County

State

Shipping Point if different

Forward By

State on this line whether we are to send by Express, Freight or Parcel Post.
Please Do Not Write In These Spaces

We do not warrant in any way, express or implied, the contents, or the description, purity, productiveness, or any other matter of any seeds, bulbs or plants, sold by us, and we will not be in any way responsible for the crop. If the purchaser does not accept those goods on the above terms, no sale is made thereof, and he must return them at once, and money will be refunded. Subject to the above conditions we make this sale at the moderate prices we charge. VICKSBURG SEED CO., Inc.

QUANTITY




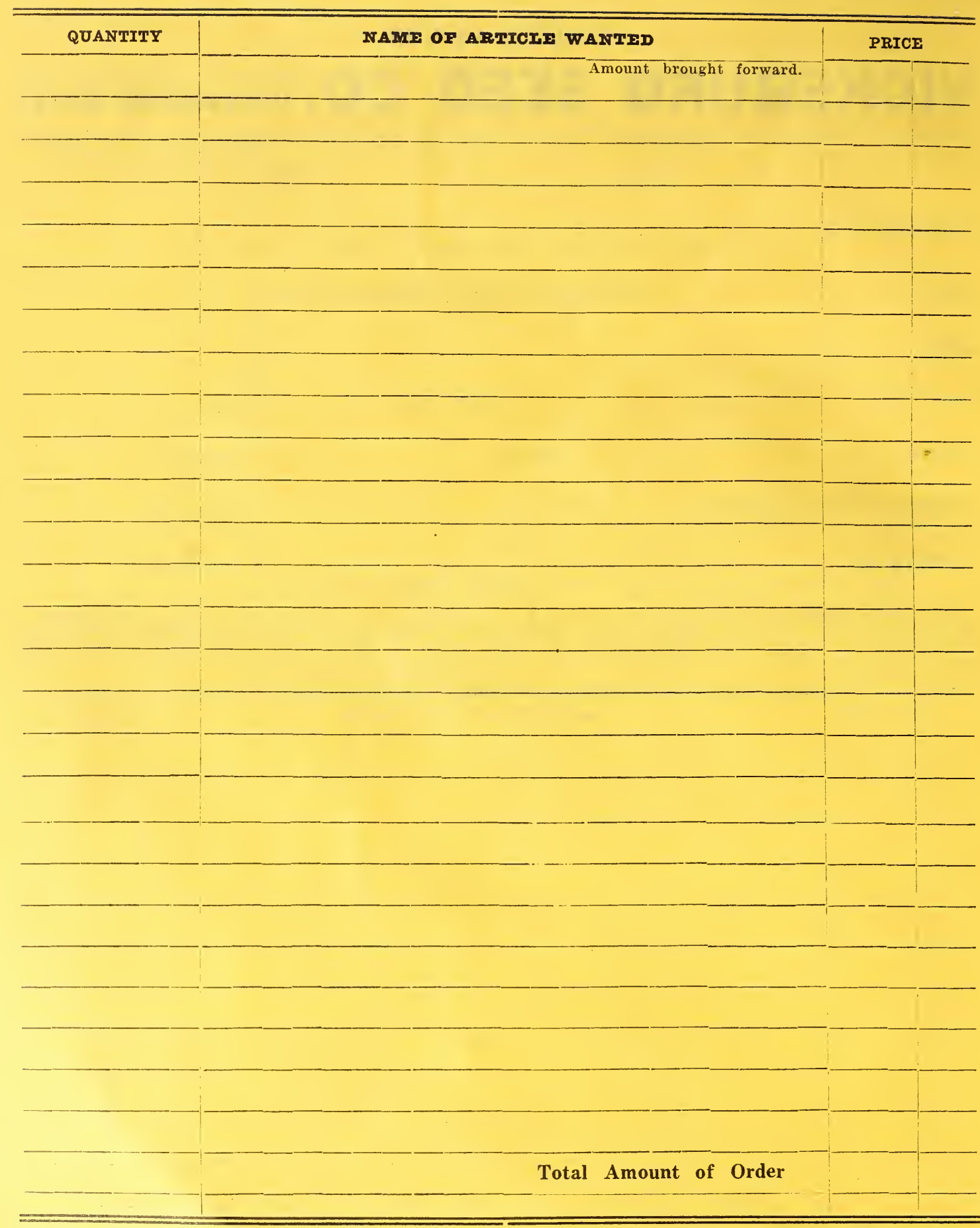

HAVE YOU FRIENDS OR NEIGHBORS INTERESTED IN BETTER FIELD, VEGETABLE AND FLOWER SEEDS? If so, please write their names below. We will send them Catalog on request, and we will send you free Flower Seeds for your trouble.

\begin{tabular}{l|l|l|l|l}
\hline INITIAIS AND NAMTE & POSTOFICE & R. F. D. & STATE \\
\hline & & & \\
\hline
\end{tabular}




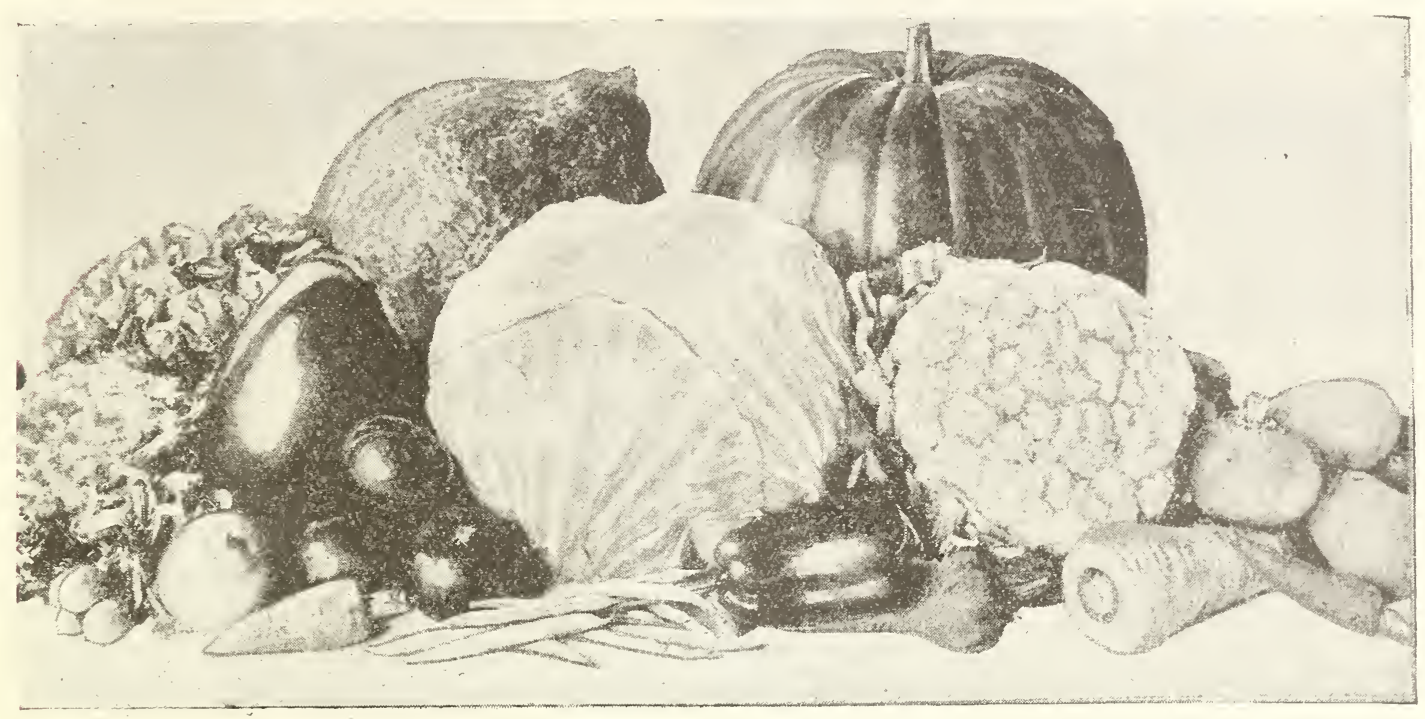

\section{ASPARAGUS SEEDS AND ROOTS}

One ounce will produce about 200 plants, or plant 40 feet of drill; 5 pounds will plant an acre. Sow early in spring 2 inches deep in rows of 18 inches apart. When one or two years old transplant into permanent bed, in furrows 4 to 5 feet apart and 2 feet between the plants. Deep loamy soil, thoroughly cultivated and heavily manured, is required for permanent bed. Complete directions on request.

COIUMBIAN IMAMLIOTH WHITE-A new and entirely distinct kind whose shoots are white and stay white as long as fit for use. Pkt., $5 \mathrm{c} ; 1$ oz., $10 \mathrm{c} ; 2 \mathrm{ozs}, 15 \mathrm{c}$; $1 / 4$ lb., 25c; 1 lb., 75c, parcel post paid. PAIMETTO-A fine variety, very large, early and adapted to all climates. Pkt., $5 \mathrm{c} ; 1$ oz., 10c; 2 ozs., $15 \mathrm{c} ; 1 / 1$ lb., $20 \mathrm{c}$; 1 ib., $60 \mathrm{c}$, postpaid.

PAIMETTO ASPARAGUS ROOTS-A saving of 1 to 2 years is effected by planting roots. For private use or for marketing on a small scale, beds should be formed 5 feet wide, with 3 rows planted in each, one in the middle and one on each side a foot from the edge; distance between the plants in the rows, 9 inches. Price, parcel post paid, 2-year roots, doz., 40c; 50 for $\$ 1.25 ; 100$ for $\$ 2.40$.

Price by express, purchaser's expense, 2 -year roots, doz., $30 \mathrm{c} ; 50$ for $\$ 1.00 ; 100$ for $\$ 2.00$.

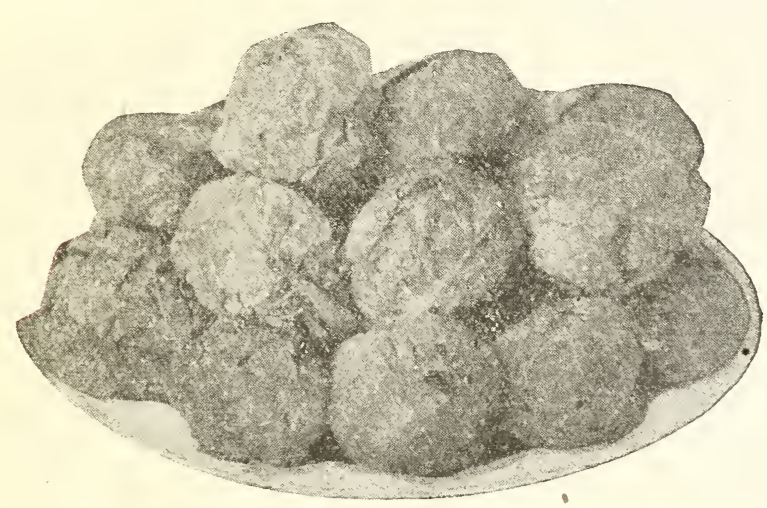

Dwarf Improved Brussels Sprouts order.

\section{ARTICHOKE}

One ounce will produce 500 plants; $1 / 4$ 1b. to the acre. Seed should be sown in hotbeds early in February to get plants that will bear first year. Transplant to open ground in April, in deep, rich, sandy loam wtih plenty of well rotted manure.

TARGI GREFN GTOBE-Produces heads like flowers, which are cooked like Asparagus. Highly esteemed. Pkt., 10c; 1/2 0z., 40c; 1 oz., 75c; postpaid.

ARTICFOKE, JFRUSAIEM-Excellent for fattening hogs. Plant in rows 4 feet wide, any time in March and April dropping the tubers 18 inches apart in tha rows; immensely productive; 3 bushels will plant an acre. Price, 1 lb., 25c; parcel post paid. Quantity price, see page 4.9.

\section{BRUSSELS SPROUTS}

You will not be disappointed if you reserve a place in the garden for some of these delicious vegetables. Include some seeds in your

One ounce will sow 200 feet of drill; or produce 2,000 plants. Sow seed for plants in frames or open ground. Set plants in early spring, and for succession up to July, making rows 3 feet apart and having the plants stand $1 \frac{1}{2}$ to 2 feet apart in the row.

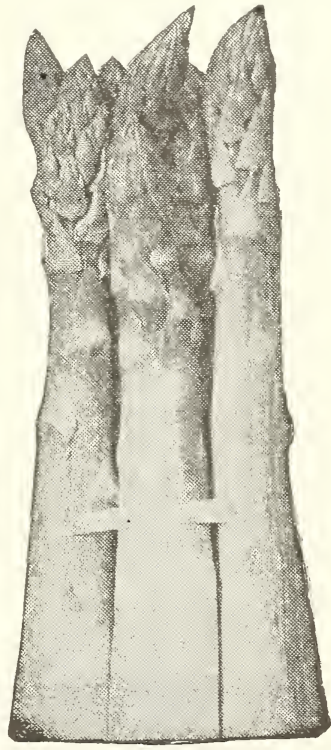

Palmetto
Brussels Sprouts are a very delicate vegetable, and deserves mor general cultivatoin than they receive. The plant belongs to the cab bage family, and should be grown and cultivated like cabbage. Very hardy; improved by frost.

DWARF IMPROVID-Bearing a large crop of small solid, tender heads. Pkt. 10c: 1 oz., $30 \mathrm{c}$ 2 oz., $60 \mathrm{c} ; 1 / 4$ lb., $\$ 1.00$, postpaid.

\section{BROCCOLI}

One ounce seed will produce about 2,000 plants, Give them the culture required for caulifower, as it is very similar. It is generally taller and the heads are more divided. Broccoli stands greater extremes of temperature than cauliflower and is better adapted for late fall plantnig. Broccoli can be sown either in the spring or fall.

FARIY WHITE CAPr-The best variety: heads white, compact and hardy; a hardy, vigorous and easily grown sort. Pkt., $10 \mathrm{c}$; $1 / 2$. oz., $35 \mathrm{c} ; 1 \mathrm{oz}, 60 \mathrm{c}$ postpaid.

See pages 40 and 41 for a complete list of sprayers and cultivators that will help to make your work a pleasure and more profitable. 


\section{BUSH BEANS}

\section{GREEN PODDED}

One pound will plant 100 feet of drill. Beans are somewhat tender, but it often pays to take some risks. Plant in warm, loamy soil at the beginning of settled, warm weather in spring, and at intervals for succession until September. Rows may be made 2 feet apart, and the Beans planted a few inches apart in the drills, or 3 or 4 beans in hills 6 to 8 inches apart. Cultivate and hoe frequently, always, however, when the plants are perfectly dry. In hoeing draw the soil up towards the rows or plants. For string beans, gather the pods clean as soon as fit for use. The plants will remain all the longer in bearing.

BURPEI'S STRINGIFSS (GRIIN POD)-This new bean produces a vine similar to the Valentine. It is several days earlier than the best strain of Valentine. The pods are green and not so round as the Valentine and less curved. The pods are stringless-absolutely so. An excellent table bean. Pkt., $10 \mathrm{c} ; 1 / 2$ lb., 20c; 1 lb., $40 \mathrm{c} ; 2$ lbs. GIANT STRINGIESS GREEN POD BEANS-A very hardy, stocky vine; pods round, green in color and of exceptionally fine quality. Stringless throughout the entire length. About a week earlier than the Red Valentine and more prolific. Pkt., 10c; $1 / 2$ lb., 20c; $1 \mathrm{lb} ., 40 \mathrm{c} ; 2 \mathrm{lbs}$. ; 5 lbs., $\$ 1.75$, postpaid.

BIACX VAIENTINE-This excellent variety is a great improvement ove* the old standard Red Valentine, being one-third longer than that quality. It is also suitable for early planting, and is extremely hardy. It will withstand early and late frost. It is an excellent shipper. arge yielder and very handsome appearance. Plit., 10c; $1 / 21 \mathrm{~b} ., 20 \mathrm{c}$; 1 lb., $40 \mathrm{c} ; 2$ lbs., $75 \mathrm{c} ; 5$ lbs., $\$ 1.75$, postpaid.

ROUND YEIIOW SIX WEEMS-The pods are 4 to 5 inches long,

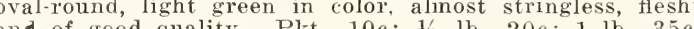
and of good quality. Pkt., $10 \mathrm{c} ; 1$

IMPROVED EXTRA, EARIY RED VAIENTINEPods are round, long, slightly curved, excellent quality. The seed we supply is produced from stock seed that was selected for both earliness and quality. Pkt., 10c; $1 / 2$ lb., 20c; 1 lb., 35c; 2 lbs., 65c; 5 lbs., \$1.50, postpaid. TENNESSEE GREEN POD-Prolific, foliage dark green; pods long, flat, irregular, bright green and excellent quality. Pkt, $10 \mathrm{c} ; 1 / 2$ lb., 20c; 1 lb., 35c; 2 lbs., $65 \mathrm{c} \cdot 5 \mathrm{lbs} . \$ 1.50$, postpaid.

\section{FIELD OR SHELLING VARIETIES}

WHITE NAVY-Vines are very prolific, producing large quantity of shelled beans per acre. Cultivate same as Marrow Beans. Pkt., 10c; 1/2 lb., 20c; 1 lb., $35 \mathrm{c}: 2$ lbs. 60c: 5 lbs., $\$ 1.40$, postpaid.

WHITE MARROW-Plant in rows 3 feet apart, dropping 2 to 3 together, a foot apart in rows. Cultivate early, as they grow rapidly, but do not work them while the dew is on the foliage. Do not cultivate after they begin to bloom. Pkt., 10c; 1/2 1b., 20c; 1 1b., 35c; 作, 50 lbs., $\$ 1.40$, postpaid.

WHITE KIDNEY-Much used for shelling when pods turn yellow so the beans are well developed. Pkt., 10c; $1 / 2$ lb., 20c; 1 lb., 35c; 2 lbs., 60c; 5 lbs., $\$ 1.40$,

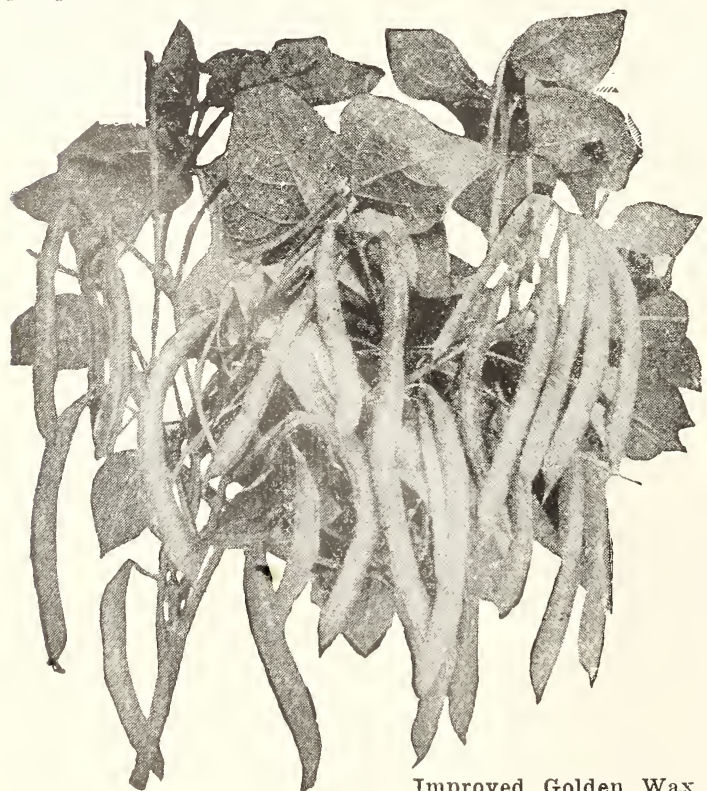

\section{BUSH BEANS - WAX PODDED}

WARDWEII'S TIDNEY WAX-A very popular, early gardeners' variety Pods large, 5 to 6 inches long, moderately stout, straight and flat, fleshy, brittle, finegrained and nearly stringless, and of good quality. Pkt. $10 \mathrm{c}, 1 / 2 \mathrm{lb} .20 \mathrm{c}, 1 \mathrm{~b} .35 \mathrm{c}, 2 \mathrm{lbs} .60 \mathrm{c}, 5 \mathrm{lbs}$. $\$ 1.40$, ppd. IMPROVED GOIDEN WAX-Rust proof. Pods are about 4 inches long, very stout, and more straight than the old Golden Wax. Pkt., 10c; 1/2 lb., 20c; $1 \mathrm{lb}$. $35 \mathrm{c} ; 2$ lbs., $60 \mathrm{c} ; 5$ lbs., $\$ 1.40$, postpaid.

CURRIE'S RUST PROOF WAX-Pods 5 to 6 inches long, flat and straight, of bright yellow color. Pkt., $10 \mathrm{c}$. $1 / 2$ lb., 20c; 1 lb., 35c; 2 lbs., $60 \mathrm{c} ; 5$ lbs., $\$ 1.40$ postpaid DAVIS WHITE IRIDNEY WAX - 6 to 7 inches long, irre and flat, very uniform and straight, stringy and fibrous, of fair quality. Pkt., $10 \mathrm{c} ; 1 / 2 \mathrm{lb}$., $20 \mathrm{c} ; 1 \mathrm{lb}$., 35c:2 lbs., 60c: 5 lbs., $\$ 1.40$, postpaid.

\section{POLE OR RUNNING BEANS}

KENTUCKY WONDER, OR OID HOMESTEADShould be kept picked so that it will continue bearing until frost. The beans are 6 to 12 inches long, tender and rich. Pkt., $10 \mathrm{c} ; 1 / 2$ lb., 25c; 1 lb., 45c; 2 lbs., 80c: 5 lbs., $\$ 1.75$ postpaid.

WHITE CREASEBACK-This variety is valuable for quality and dark green color. Pkt., 10c; 1/2 lb., 25c; 1 lb., $45 \mathrm{c}$; 2 lbs., 80c; 5 lbs., $\$ 1.75$, postpaid SCOTIA OR STRIPED CREASFBACK-This is the real Cornfield Bean that you have read so much about. If you want a bean to plant in your corn, this is your one choice. It will produce the kind of results that you'll expect. Pkt., 10c; $1 / 2$ lb., 25c; 1 lb., 45c; 2 lbs., $80 \mathrm{c} ; 5$ lbs., $\$ 1.75$, postpaid.

RED SPICKIED CUT SHORT-Pods nearly 4 inches long. stout, straight and flat, stringy, fine-grained and light green color, of fair quality. Price: pkt., $10 \mathrm{c} ; 1 / 2 \mathrm{lb} ., 25 \mathrm{c}$ : 1 lb., 45c;2 lbs., 80c; 5 lbs., $\$ 1.75$, postpaid.

MCCASIAN POII-When allowed to ripen shell beans are inost excellent for winter use, being pure white. Pkt., 10c $1 / 2$ lb., 25c; 1 lb., 45c; 2 lbs., 80c; 5 lbs., $\$ 1.75$, postpaid. IAZY WIFE POLE BEANS-A late variety of excellent quality. Fruits borne in clusters, pods average six inches in length; very fine flavor, round and stringless. Seed large, round and clear white. A fine variety to use dry. Price: Per pkt., 10c; $1 / 2$ lb., 25c; 1 lb., 45c; 2 lbs., $80 \mathrm{c} ; 5$ lbs., $\$ 1.75$, postpaid.

GOIDEN CIUSTER WAX-An excellent early wax pod ded pole bean. The vines are large, vigorous and hardy. with large, light green leaves. The pods are 6 to 8 inches long, extremely straight and flat; very fleshy, fine grained. good quality: color light waxy-yellow. Pkt., 15c; 1/2 lb. $30 \mathrm{c} ; 1$ lb., $50 \mathrm{c} ; 2$ lbs., $90 \mathrm{c} ; 5$ lbs., $\$ 2.00$, postpaid.

KENTUCKY WONDER WAX-This is one of the earliest of the wax podded sorts, and similar to the green pod. ded Kentucky Wonder, but the pods are broader. The pods are very long, handsome light yellow, often over 8 inches long, very fleshy, brittle but stringy. Pkt., 15c: $1 / 2 \mathrm{lb}$. $30 \mathrm{c} ; 1$ lb., $50 \mathrm{c} ; 2$ lbs., $90 \mathrm{c} ; 5$ lbs., $\$ 2.00$, postpaid. Improved Golden Wax For prices in larger quantities see price list page 49 . 


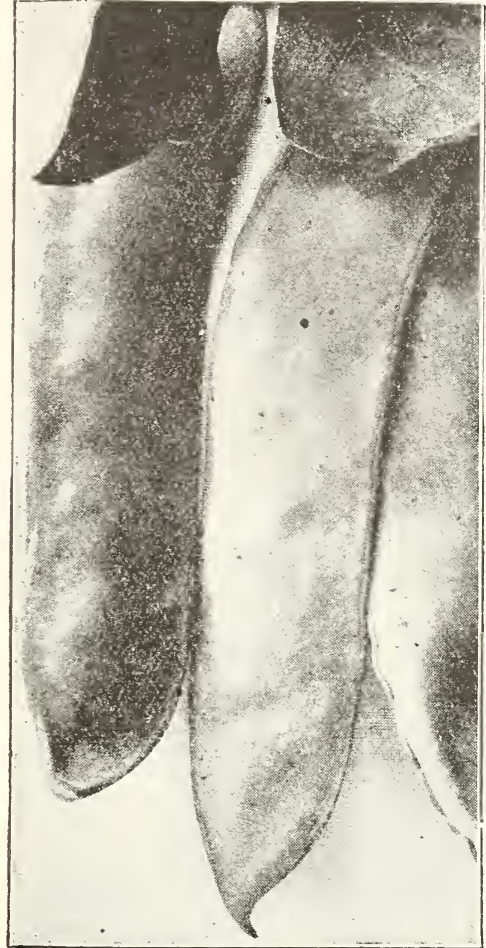

irge White Lima

\section{TABLE BEETS}

One ounce will sow 50 feet of drill; 5 to 6 pounds to an acre. Fibrous loam, well drained and well enriched, will raise good beet crops. For early table beets, have drills 16 to 20 inches apart, and sow the seed about 1 inch deep, as early as the ground can be put in good shape. Or, seed may be sown under glass four weeks sooner and the young seedlings transplanted to open ground to give an extra early crop. Give thorough and clean cultivation, and thin the plants to 3 to 4 inches apart in the rows.

CROSBY'S IGYPTIAN-This is the earliest in the market. It does not closely resemble the original Egyp. tian except in its extreme earliness. Roots a flat tened globe shape; skin very dark red, flesh a trifle lighter in color and lightly zoned; tops small. Pkt., $5 \mathrm{c} ; 1 \mathrm{oz}$, $10 \mathrm{c} ; 2$ oz., $15 \mathrm{c} ; 1 / 4$ lb., $25 \mathrm{c} ; 1$ lb., $85 \mathrm{c} ; 5$ lbs., $\$ 3.50$, ery best for home or market garden and for canning purposes. Roots uniformly smooth, of medium size, and globe-shaped uniformly smooth, of medium size, and globe-shaped; upright, dark green! shaded red; quality the best. Pkt. $5 \mathrm{c} ; 1$ oz., $10 \mathrm{c} ; 2$ oz., $15 \mathrm{c} ; 1 / \mathrm{t} 1 \mathrm{b.}, 25 \mathrm{c} ; 1 \mathrm{lb}$. $90 \mathrm{c} ; 5$ lbs., $\$ 4.00$, postpaid.

BARIY ECIPSE-An early variety, especially desirable for the home garden, and used for bunching. The roots are medium size, round, bright deep red with small tops. The flesh is bright red, zoned with pinkish white, rery sweet, crisp and tender. Pkt., $5 \mathrm{c} ; 1 \mathrm{oz}$, $10 \mathrm{c} ; 2$ oz., 15c; $1 / 4$ lb., $25 \mathrm{c} ; 1$ lb., $80 \mathrm{c} ; 5$ lbs., $\$ 3.50$, postpaid.

PARIY BIOOD TURNIP, IMPROVEDAn extra select stock of the old standard table beet; roots nearly round or slightly flattened, bright red, zoned, and of good quality. Not as early as Detroit, with a larger, coarser top. Pkt., 5c; 1 oz., 10c: 2 oz., 15c; 1/4 lb., 25c: 1 lb., $80 \mathrm{c}$; 5 lbs., $\$ 3.50$, postpaid.

MARIET WONDER-Our gardeners favorite, owing to its extreme earliness and uniformity in both shape and color. It is without a doubt the best beet for the home, gardener or for canning. The tops are small and upright in growth. The leaves dark green, shaded red. The roots are medium size, globular, very smooth and of dark blood red color, while the flesh is a deep vermilion red, zoned with lighter shade. It is unsurpassed in quality. Pkt., $5 \mathrm{c}$; 1 oz., 15c; 2 ozs., $25 \mathrm{c} ; 1 / 4$ lb., $40 \mathrm{c} ; 1$ lb., 1 Oz., $15 \mathrm{c}$; 2 OzS., $25 \mathrm{c}$; $1 / 4$

\section{LIMA BEANS POLE VARIETIES}

One pound will plant about 150 hills. Pole Limas require warm, rich, soil. Plant when the soil has become well warmed through in ed for support they should be set not less than 4 feet apart each way. CAROTIN good commercial fertilzer or poultry manure. The seed beans are relr small and white, on the order of Hen derson's Bush Lima. The plants are of large growth, verc early, igorous and productive, and will stand more heat and drouth than any $20 \mathrm{c} ; 1$ lb., $35 \mathrm{c} ; 2$ lbs., $70 \mathrm{c} ; 5$ lbs., 1.60, postpaid.

RGF WIITE IIMA-This well known variety is one of the best the larger varieties for planting in the South. The vines are tall and

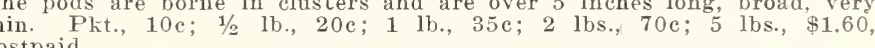

KING OF THE GARDEN-An improved strain of the Large Whit Lima. The pods are about an inch longer, proportionately wider, and s a standard sort and one of the best for main crop. The seed are large, ovoid, flat, white, with slight greenish tinge. Pkt., $10 \mathrm{c}$ 20c; 1 lb., 40c; 2 lbs., 75c; 5 lbs., $\$ 1.65$, postpaid.

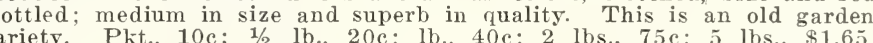

\section{DWARF OR BUSH VARIETIES}

One pound will plant 100 feet of row, or 3 pecks to the acre. Bush require the same cultivation as stated above for Pole Limas, wows should be 2 feet apart and 6 inches of space beween each plant in the row. to its extreme earliness and productiveness. The plants are without runners but continue to grow and set unti stopped by frost. The leaves are small and very dark green. Pkt., 10c; 1/2 lb., 20c; 1 lb., 40c; 2 lbs., $75 \mathrm{c}$ 5 lbs., \$1.60, postpaid.

FORDHOOK BUSH-This is the only variety with a stiffy, erect bush form habit, branching freely but branches of upright growth. The pods are produced in $\operatorname{large}$ clusters, medium green, about 5 inches long and each containing 4 to 5 large beans of finest quality. Pkt., 10c; $1 / 2$ lb., 25c; 1 lb., $45 \mathrm{c} ; 2$ lbs., $80 \mathrm{c} ; 5$ lbs., BURPEF'S IMPROVED BUSF-This is one of the earliest of the large seeded Limas. The plants are vig. orous and productive. The pods are medium green, very large, about 5 inches long, containing 4 unusually thick and very large beans of excellent quality. Pkt., 10c; $1 / 2$ lb., $25 \mathrm{c} ; 1$ lb., $45 \mathrm{c} ; 2$ lbs., $80 \mathrm{c} ; 5$ lbs., $\$ 1.75$, postpaid.

For prices in larger quantities see price list page 49 .

IONG SMOOTI BIOOD-A standard long, late va riety, roots smooth, rather slender, flesh deep purplish red. It is of good quality and keeps well through $t \mathrm{~h} e$ winter. Pkt 5 c; 1 oz., 10c; 2 oz., $15 \mathrm{c}$; 850.5 lbs postpaid.

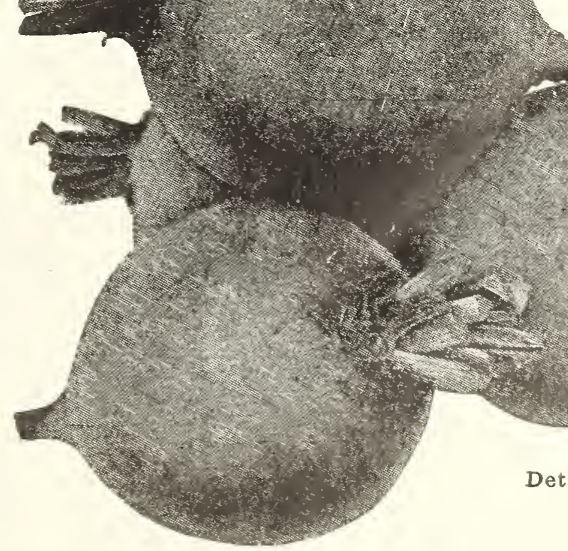

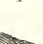




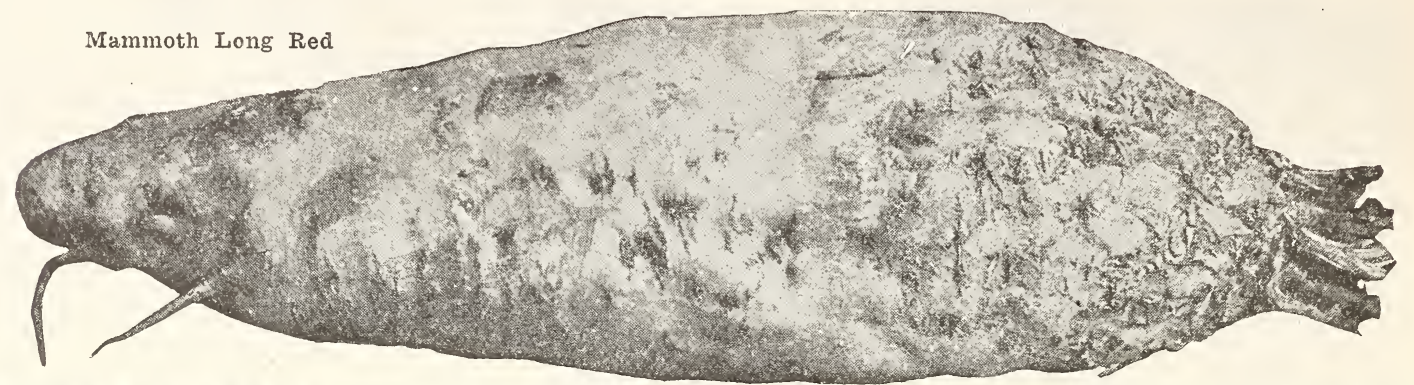

SUGAR 3EETS One ounce will sow 50 feet of drill; 6 pounds for an acre. The Sugar Beets are desirmay be used for the table. The best soil is a rich, friable sandy, or clayey loam. Rich, mucky soil will often give immense yield of roots which, though excellent for feed, are of ltitle value for sugar making. Plant early in spring in drills 2 to $2 \frac{1}{2}$ feet apart, and about 1 inch apart in the row, covering with about $11 / 2$ inches of fine soil firmly pressed down. Cultivate frequentiy. When about 3 inches high begin thinning and continue at intervals until the roots stand about 10 inches apart. The culture of the IMangel Wurzel, also called IMangel, Cattle Beet and Field Beet, is much the same as for Sugar Beets.

We list only those varieties that are known to be the best producers of beet sugar.

IANE'S IMPERIAI-This beet will yield almost as much in bulb as the best mangels and contains more sugar. The roots are smooth, broad at the top and gradually taper. Flesh snow white and crisp. Pkt., 5c; 1 oz., 10c; 2 oz., 15c; postpaid.

KIEIN WANZIFBEN-The roots are larger than Vilmorin's Improved and is hardier and easier grown. The tops are rather large and the leaves slightly waved. It is the largest yielding and best for sugar making. Pkt., 5c; 1 oz., $10 \mathrm{c} ;$ lbs., \$3.00, postpaid.

GIANI FEEDING SUGAR-Sometimes called Half Sugar Mangel, and one of the most desirable for stock feeding, of the most desirable for stock feeding, harvested than other sorts. It has high nutritive value, being especially rich in sugar. The upper portion of the roots is soft pink, shading lighter toward the bottom, where the lower portion for more than a third of the length is white. Flesh white. Pkt., 5c; 1 oz., $10 \mathrm{c} ; 2$ ozs., $15 \mathrm{c}$; $1 / 4$ lb., 20c; 1 lb., $75 \mathrm{c}$; 5 lbs., $\$ 3.00$, postpaid.

\section{Carrots}

\section{MANGEL WURZEL}

The Mangel Wurzel is grown largely for stock feeding.

MAMIMOTX IONG RED-The largest stock beet yields 40 to 50 tons to the acre. Will grow in land containing more alkali than any other beet. All stock except horses eat it readily. The roots are very large, uniformly straight and the flesh is white, tinged with rose. Pkt. $5 \mathrm{c} ; 1$ oz., 10c; 2 ozs., 15c; 1/4 lb., 20c 1 lb., 75c; 5 lbs., $\$ 2.00$, postpaid.

GOIDEN TANKARD-The tops are comparatively small, with the 1-leaf stalk and veins distinctly tinged with yellow. The neck is small. The roots are large, ovoid, but with bottom usually of larger diameter than top, light gray above the ground, deep orange below. The flesh is yellow, zoned with white. Fkt., $5 \mathrm{c} ; 1$ oz., $10 \mathrm{c} ; 2$ ozs., $15 \mathrm{c} ; 1 / 4$ lb., $20 \mathrm{c} ; 1$ lb., $75 \mathrm{c} ; 5$ lbs., $\$ 3.00$, postpaid.

\section{CHERVIL}

Used for flavoring or garnishing. Sow in early spring in rich soil, and when plants are large enough, transplant to a foot apart. Price, pkt., 10c; 0z., 25c; 2 oz., $50 \mathrm{c}$, postpaid. may be sown any time until the middle of July. Sow in rows about 15 inches apart, the plants. One ounce of seed will sow 100 feet of drill; 2 to 3 pounds to the acre. IONG ORANGE-An old standard and very popular variety, growing to large: size; fine for market; one of the best varieties "for stock feeding. Pkt., 5c; 1 oz., 10c; 2 ozs., 15c: 1/4 1b., 25c; 1 lb., $75 \mathrm{c}$; 5 lbs., $\$ 3.50$, postpaid.

FARIX SCARLFT HORN-Not large, but a favorite for early crop Small tops, stump rooted, orange flesh and fine grain. Pkt., $5 \mathrm{c} ; 1$ oz., $10 \mathrm{c} ; 2$ ozs., $15 \mathrm{c} ; 1 / 4 \mathrm{lb.}, 30 \mathrm{c} ; 1 \mathrm{lb}, \$ 1.00 ; 5$ lbs., $\$ 4.50$, postpaid.

OX FIART-Stump rooted, 3 or 4 inches in diameter, flesh bright orange, fine grained and sweet; very productive. Where other varietie require digging, Ox Heart is easily pulled. Pkt., 5c; 1 oz.; 10c; 2 ozs. $15 \mathrm{c} ; 1 / 4$ lb., $30 \mathrm{c} ; 1$. 1b., $\$ 1.00 ; 5 \mathrm{lbs}$., $\$ 4.50$, postpaid.

\section{CAULIFLOWER}

Cultivate like cabbage. Sow in January or February for early crop; May or June for late. Transplant to rich, moist soil; manure heavily and water freely. When heading begins, fasten leaves over top of head to whiten. One ounce of seed makes 2,000 plants. We handle only the very best. quality seed.

EARIY SNOWBAII-The earlest maturing strain of the true type of cauliflower. A good forcing variety, and can also be used as a late crop for winter. Heads are of medium size, solid, round, very white, amking a very attractive appearance. In quality this variety is unsurpassed, being crisp; tender and sweet. Pkt., $25 \mathrm{c} ; 1 / 40 \mathrm{z} ., 75 \mathrm{c} ; 1 / 2$ oz., $\$ 1.25 ; 1$ oz., $\$ 2.00$, postpaid.

DANISH DRYWFATFrR-This variety is especially valuable in sections subject to long dry seasons, as it will do well and produce fine heads in lack of moisture. The heads grow to a large size, and are very solid but in quality perhaps not as tender as Early Snowball. Pkt.,

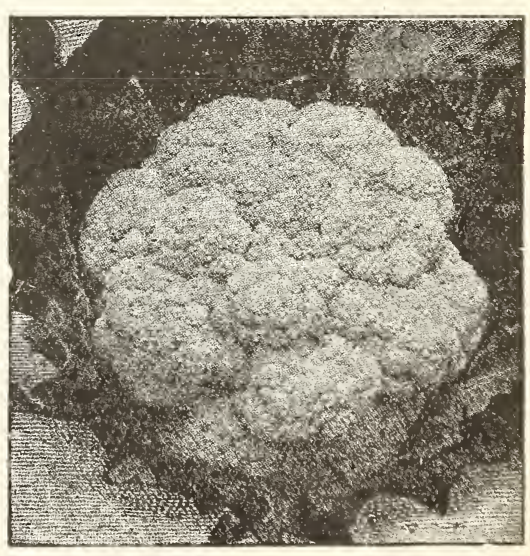

Early Snowball 


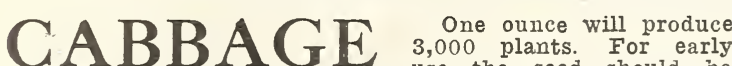
use the seed should be inches apart each way. About the end of March they may be transplanted into the garden in rows 3 feet apart, setting the plants 18 inches apart each way. For late use, sow the seed about the middle of May, or sowings can be made up to July 10, in a finely prepared seed bed, later transplanting to rows 3 feet apart, setting the plants $2 \frac{1}{2}$ feet apart.

PARIY JIRSPY WAKFFIEID-A leading variety and one of the best for private or market gardeners' use; conical shape. Pkt $5 \mathrm{c}, 1$ oz, 25c; 2 ozs, $40 \mathrm{c} ; 1 / \mathrm{lb}$., $75 \mathrm{c} ; 1$ lb., $\$ 2.75$, postpaid.

CHARIJSTON IARGI WAKrFIrID-This is a few days later than the Early Jersey Wakefield, but makes a larger and firmer head. We strongly recommend it as the best main crop early cabbage grown, for the home garden and market. Our seed of this is grown from a specially selected stock. Pkt., 5c; 1 oz., $25 \mathrm{c} ; 2$ ozs., $40 \mathrm{c}$; $1 / 4$ lb., $75 \mathrm{c} ; 1$ lb., $\$ 2.75$, postpaid.

COPFIHAGFN MARIFT-The earliest large round or flat-head sort. The ripening is early and uniform, maturing at one time and almost with Early Jersey Wakefield. Considering its early season, the heads are remarkably large, averaging ten pounds in weight. It has few outer leares, which permits close planting, and it grows close to the ground on a short stem. Pkt, $5 \mathrm{c} ;$ oz., $35 \mathrm{c} ; 2$ ozs., $60 \mathrm{c} ; 1 / 1$ lb., $\$ 1.00 ; 1$ lb., $\$ 3.50$, postpaid.

DARIY FIAT DUTCF-Sure solid header; weighs 10 to 12 pounds each head, even size, mature about same time as "Early Summer," a standard Early; it stands long without bursting; as second early it is one of the best. Pkt., 5c; oz., 25c; 2 ozs., $40 \mathrm{c} ; 1 / 4$ lb., $65 \mathrm{c} ; 1 \mathrm{lb}$. $\$ 2.25$, postpaid.

SUCCFSSION-This is one of the earliest of the very large heading sorts. The large, handsome, oval shaped heads make them profitable for both home and market gardens. Pkt., 5c; oz., 25c; $1 / 4$ lb., $75 \mathrm{c} ; 1$ lb., $\$ 2.50$, postpaid.

ATI SEASONS-Solid round heads, flattened on top. This cabbage has the ability to withstand the hot sun and dry weather and is good for autumn as well as summer use. Pkt., $5 \mathrm{c} ; 1$ oz., $30 \mathrm{c} ; 2$ oz., $50 \mathrm{c} ; 1 / 4 \mathrm{lb}$., $75 \mathrm{c}$; lb., $\$ 2.50$, postpaid.

PARIY DRUMHFAD-A second early, large, round, solid-heading variety. This we consider the best for following Charleston Wakefield; it matures about ten days later. Pkt.. $5 \mathrm{c} ; 1$ oz., $25 \mathrm{c} ; 2$ ozs., $40 \mathrm{c} ; 1 / 4 \mathrm{lb}$., $65 \mathrm{c} ; 1$ lb., $\$ 2.25$, postpaid.

EARIY IURIKA-This is a valuable extra early variet5 with round, slightly flattened solid heads, coming into use as early as the Wakefield varieties. Pkt., $5 \mathrm{c}$; $1 / 2$ oz., $25 \mathrm{c}$; 1 oz., $50 \mathrm{c}$; 2 ozs., $75 \mathrm{c}$; $1 / 4$ lb., $\$ 1.25 ; 1$ lb., $\$ 3.85$, postpaid.

CEINESI (PI TSAI)-This variety is often called Celery Cabbage, the leaves when young are crimped, of light green color. The plant as it matures becomes more upright and forms heads much like Cos Lettuce.

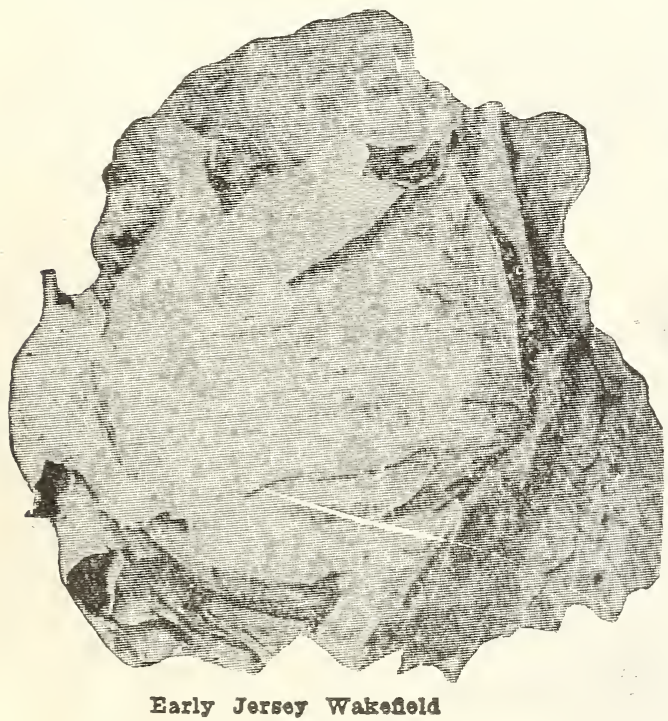

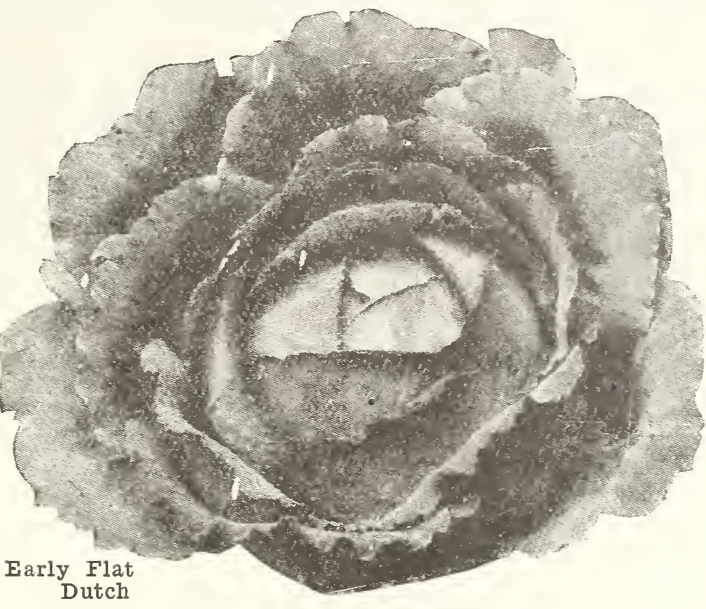

The inner leares blanch an attractive light yellow or creamy white with midribs. It is of distinctive flavor and is served as a salad like lettuce or cooked like asparagus. Pkt., 10c; oz., 35c; 2 ozs., 60c; $1 / 4 \mathrm{lb}$. $\$ 1.00 ; 1$ lb., $\$ 3.50$, postpaid.

IARGI DRUMREAD SAVOY-The best and larg. est heading of the Savoy Cabbage. Few people seem to know the delicious flavor of Savoy Cabbage. It is far superior to the flat-leaved sorts, and as tender as Cauliflower after frost. Pkt., 5c; oz., 35̄c; 2 ozs., 60c $1 / 4$ lb., 90c; 1 lb., $\$ 2.75$, postpaid.

IARGP IATE DRUMFEAD-This is equally as good Cabbage as the Flat Dutch, differing only in the shape of the head, not being so flat. It will stand the changeable conditions of weather of the South better than most an sort. Pkt., $5 \mathrm{c}$; ob., $25 \mathrm{c} ; 2$ ozs., $40 \mathrm{c} ; 1 / 4$ lb., $75 \mathrm{c}$ 1 lb., \$2.25, postpaid.

MAIMOTH ROCK RED-This is the largest variety of Red Cabbage and produces heads which are remark ably solid, more so than any other kind. The heads are round with spreading outer leaves and matures a a late season. Pkt., 10c; 1 oz., $35 \mathrm{c} ; 2$ ozs., 60c, post paid.

AII FEAD EARIY-The largest heading of the second early sorts, of excellent quality. The deep flat heads are remarkably solid, and very uniform in size, of a very compact growth, having a few outer leaves can be planted as close as the Wakefield. Pkt., $5 \mathrm{c}$ 1 oz., $25 \mathrm{c} ; 2$ oz., $40 \mathrm{c} ; 1 / 4$ lb., $75 \mathrm{c} ; 1$ lb., $\$ 2.50$.

IARGE IATE FIAT DUTCF-The best of the later varieties. Large heads of excellent quality which keeps well through the winter. It is the great favorite among market gardeners on account of its excellent shipping qualities. Pkt., 5c; $10 \mathrm{oz}, 25 \mathrm{c} ; 2 \mathrm{oz}, 40 \mathrm{c} ; 1 / 4$ lb., $65 \mathrm{c}$ 1 lb., $\$ 2.25$, postpaid.

\section{DANDELION}

For good, tender greens plant in deep, rich soil. Sow in rows 18 inches apart and thin Cultivate and keep clean and plants will be large enough for use the following spring. This crop is handled and used in the same way as spinach. When roots are desired sow in fall, cultivate well for use the following fall. Roots are used for medicinal purposes. One ounce will sow 100 feet of row. IMPROVID THICK-IMAVID-Unsurpassed in thicknes of leaf and deep green color. It is compact and forms an upright regular turf at the center. Pkt., $10 \mathrm{c} ; 1 / 2 \mathrm{oz} ., 35 \mathrm{c}$; 1 oz., $60 \mathrm{c}$, postpaid.

\section{CHICORY}

Chicory is grown for the large, thick roots, which are dried, roasted and ground, as a substitute or adulterant for coffee. The leaves are also used as a salad during the early spring months. To secure large, smooth roots, the soil should be light, rich, and deeply worked, and the plants should be thinned out to stand 4 to 6 inches apart. One ounce will sow 100 feet of row.

IARGE-ROOTED postpaid.

WITTOOF-CFICORY, or FRTNCF FNDIVF-Plit.

oz, $50 \mathrm{c}: 2$ oz, $90 \mathrm{c}$, postpaid.

\section{CRESS, OR PEPPER PLANT}

One ounce will sow about 15 square feet-A well-known, ungent salad. Sow at frequent intervals to keep up a succession, as it soon runs to seed.

CURIPD, or PEPPER GRASS-Pkt., $5 \mathrm{c} ; 0 \mathrm{z}, 20 \mathrm{c} ; 2$ oz.

c; $1 /$ lb. 50c; 1 lb., $\$ 1.25$, postpaid. 
C $\mathrm{A}, \mathrm{T}, \mathrm{T} \begin{gathered}\text { Celery does well in muck land but can be } \\ \text { grown in any good-preferably moist-garden }\end{gathered}$ grown in any good-preferably moist-garden soil. Sow in rich soil, in boxes inside or in frames under glass. When plants are 2 inches high, transplant again in boxes or cold frames 2 inches each way. Seeds germinate slowly in plants 6 to 8 inches apart in the trench. When plants are full grown fill in the trench for blanching. One ounce of seed will produce 3,000 plants. WFITE PIUIME-An attractive quick growing early variety, well known for the short time necessary in blanching. Suitable for the home garden and market on account of earliness. Imported stock. Plt. 50 ; $10 \%$ $25 \mathrm{c} ; 1 / 4$ lb., $75 \mathrm{c}$, postpaid.

GOIDFN SEIF-BIANCIING-This grand Celery is of French origin. It has the same self-blanching habits as White Plume, but is heavie and more compact, though not so early. l rows to good size, is very tender and free from strings, the heart large and solid, crisp, brittle, of excellent quality, and beautiful golden color. Pkt, $5 \mathrm{c} ; 10 \mathrm{0z}, 50 \mathrm{c} ; 1 / \mathrm{lb}$. $\$ 1.25$, postpaid.

GIANT PASCAT-The stalks are large, thick, solid and crisp. Fine keeper. Has an agreeable almond flavor and is absolutely free from bitter ness. It requires but little earthing up to blanch and keeps its fresh ness a long time after being marketed. Pkt., 5c; 1 oz., 25c; 1/ $1 b$. $75 \mathrm{c}$, postpaid.

\section{CELERIAC OR ROOTED CELERY \\ One ounce for 5,000 plants.}

IARGE SMOOTH PRAGUE-A turnip-rooted celery which keeps we! for winter use. Used largely for flavoring soups. The variety offered here is perhaps the best and most widely known. Produces a smooth and almost round root. Pkt., 5c; 1 oz., 25c; 1/4. lb., 75c, postpaid.

\section{CORN SALAD, OR FETTICUS}

One ounce will sow about 18 square feet-Sow in September or October. Large, round-leaved. Pkt., 5c; oz., 15c; 2 oz., 25c; 1/i lb., 35c; lb. $\$ 1.25$; parcel post paid.

\section{GUCUMBERS}

One ounce will plant 50 hills 2 pounds will plant one acre. For very early cucumbers plant in paper pots or dirt bands, in hotbeds, about the second week in IMarch. Transplant as soon as the weather permits. In the open, plant about the first of April, as soon as the weather becomes settled, in hills 4 feet each way; thin to 3 of the sturdiest plants when they begin to vine. The soil should be a rich, sandy loam. Continue to plant for succession until the middle of July. Cucumbers should be gathered when large enough for use, whether required or not, as ripening destroys their productiveness. IMPROVED IONG GREFN-A standard variety used for slicing while young. With age it turns to a rich golden yellow, when it can be used for sweet pickles. This cucumber should be in every garden where general purpose variety is most desired, as the various stages of development of the fruit can be utilized for a large assortment of delicious dishes. Pkt., 5c; $10 \mathrm{oz}, 15 \mathrm{c} ; 2$ oz, 25c; 1 1b. $40 \mathrm{c} ; 1$ lb., $\$ 1.25$;

lbs., $\$ 5.25$, postpaid.

IMPROVED EARIY WHITE SPINE-One of the very earliest and best known of the White Spines; short, square-ended, rather three-cornered type; very productive; fine for slicing or pickles; medium green color with white spines. Pkt., 5c; 1 oz., $15 \mathrm{c} ; 2$ oz. $25 \mathrm{c} ; 1 / 4$ lb., $40 \mathrm{c} ; 1$ lb., $\$ 1.25 ; 5$ lbs., $\$ 5.25$, postpaid.

KIONDYKE- very hardy and productive. Fruits are 8 inches in length. Are of uniform shape and size. striped at ends. The dark green color is retained much longer and is affected less by the hot sun than any other variety known to us. Used largely for shipping. Pkt., $5 \mathrm{c} ; 1$ oz., $15 \mathrm{c} ; 2$
oz., $25 \mathrm{c} ; 1 / 1 \mathrm{~b} ., 40 \mathrm{c} ; 1 \mathrm{lb} ., \$ 1.25 ; 5$ lbs., $\$ 5.25$, postpaid.

FARIY CIUSTPR - An early and very productive variety. The vines are hardy and very vigorous, bearing fruits in clusters of two or three. The fruits are short, truits in clusters of two or three. The fruits are short, and tender. This sort is planted in many sections for the home orrden. It is extensively used for pickling as well as for slicing. Pkt. 2 oz. $25 \mathrm{c} ; 1 / 1$ $\$ 1.25 ; 5$ lbs $\$ 5.25$, ppd.
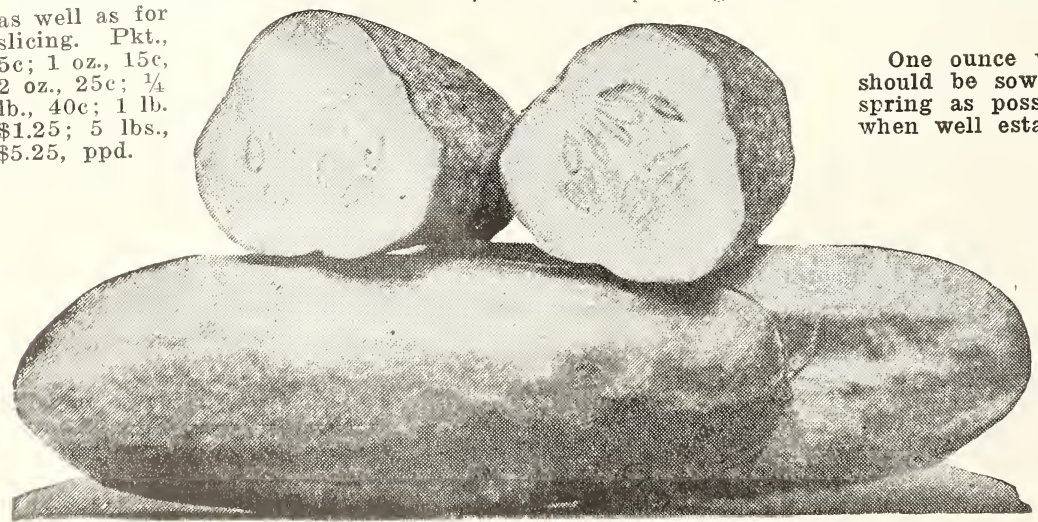

GHIRIRIN or BURR Grown exclusively for pickle and should be picked while young and tender. Fruit small, covered with pines; color light green. Pkt., $10 \mathrm{c}$ 1 oz., $25 \mathrm{c} ; 2$ oz., $40 \mathrm{c} ; 1 / 4$ lb., $60 \mathrm{c} ; 1$ li., \$2.00, postpaid JAPANFSE CIIMBING-A distinct climbing sort for covering fences or trellises; fruit 10 inches long, thick, crisp and fine quality; color dark green. Pkt., $5 \mathrm{c} ; 1$ oz., 20c; 2 oz., 35c; $1 / 4$ lb., 60c; 1 lb., $\$ 2.00$ CUMBFRIAND PICKIF-This is a variety of the White spine type. Very hardy and a strong rapid grower, and gives a very prolific yield The flesh is very firm, crisp and tender at all stages. Excellent for pickles and slicing. Pkt., 5c; 1 oz., $15 \mathrm{c} ; 2 \mathrm{oz}, 25 \mathrm{c}$ 1 lb., 40c; 1 lb., $\$ 1.50$, postpaid.

DAVIS PFRFAC-An extra long, dark green type of White Spine; retains its color and good qualities long after being picked; fruits exceptionally long, smooth and tapering at both ends; flesh crisp, solid, with few seeds; mid-season. Pkt., $5 \mathrm{c} ; 1$ oz., $15 \mathrm{c} ; 2$ oz., $25 \mathrm{c}$;

\section{KOHL RABI}

One ounce will sow 200 feet of row. Seed should be sown in light, rich soil, as early in spring as possible, in rows $1 \frac{1}{2}$ feet apart and when well established thin to 6 inches apart in the row. Plantings at intervals of ten days will give a succession until hot weather, when they fail to grow well. Plantings may be made the latter part of August for fall use. The edible part of Kohl Rabi is the turnip-shaped bulb formed above the ground.

FARIY WHITE VIFNNA-

This rariety is extremely early with distinctly small top. The hulbs are of medium size, very light green or nearly white, and are of best quality for the table if used when about 2 inches in diameter. Pkt., $10 \mathrm{c} ; 1$ oz., $30 \mathrm{c}$ 3 oz., 50c; 1/4 lb., 75c; 1 lb. $\$ 2.75$, postpaid 


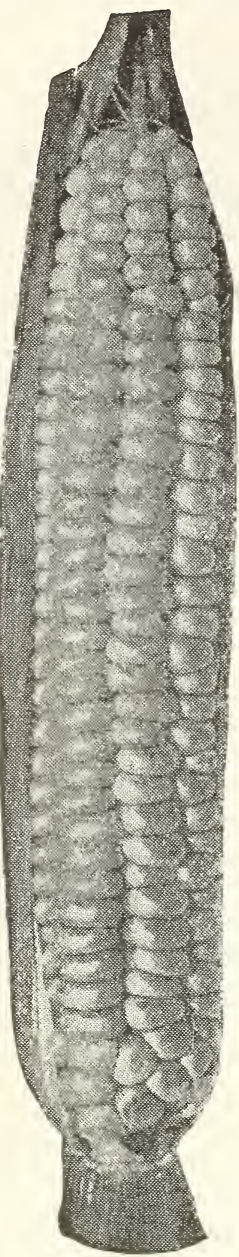

\section{Sweet and Garden Corn}

One pound will plant 200 hills; 14 pounds will plant one acre. Sweet Corn varies greatly in hardiness, earliness, size and sweetness. The early sorts grow only 3 to 5 feet high and may be planted when the trees are starting out in leaf, about the middle of March, in rows 3 feet apart, making the hills about 1 foot apart. The later and sweeter varieties are more tender and should not be planted until the trees are in full leaf or the seed will rot in the ground. Plant garden corn in rows 3 feet apart, making the hills 18 inches apart in the rows.

EXTRA EARIY ADAMS-Hardiest and earliest variety, but not a sweet corn. Brings a oood price when first offered on the market. Pkt., 10c; 1 lb., 25c; 2 lbs., $45 \mathrm{c}$; $5 \mathrm{lbs}$.. \$1.00, postpaid.

ADAMS IARGE EARLY-Similar to Adams Earls, but two weeks later, and has much larger ears. This and the Adams Extra Early are very hardy and can be planted earlier than sweet corns. Has small stalks and can be planted ciose. Pkt., 10c; $11 \mathrm{~b} ., 25 \mathrm{c} ; 2$ Ibs. $45 \mathrm{c} ; 5$ lbs., $\$ 1.00$ postpaid.

GOIDEN BANTAM-Finest home garden variety, and in a class by itself for quality. Superior in many ways to other Sweet Corn. colored kernels. We cannot recommend this variety too highly for the home garden. It is important that the corn be picked about 3 to 4 days after it has taken on a yellow hue. If picked later than this it is apt to be over ripe and cook hard. Pkt., 10c; 1 1b., 35c 2 lbs., 60c; 5 lbs., $\$ 1.25$, postpaid.

COUNTRY GENTIEMAN-A fine mid-season variety, sometimes called "Shoe Peg," owing to the shape of the kernels. Cobs are very small, thickly covered with white, slender kernels. Very sweet and tender. Very prolific and remains ready for use longer than an other kind. Pkt., 10c; 1 lb., 35c; 2 lbs., 55c; 5 lbs., \$1.10, postpaid. STOWIII'S FVRRGREgN-A most popular main crop rariety, and splendid for table use, the quality being excellent. The stall are of strong growth, about 6 feet high; the 12 -rowed ears are about 8 inches long and keep in table condition a remarkably long time Our stock has been carefully grown and selected. This is one of the best known of the late sorts. Pkt., 10c; 1 lb., 30c; 2 lbs $55 \mathrm{c} ; 5$ lbs.; $\$ 1.25$, postpaid.

MAMMOTH or LARGE SUGAR-This tall-growing sugar corn produces the largest ears of ans sweet corn. The ears are often 12 inches long and are noted for their sweetness and delicious quality. The grain is pure white, and the ears remain long in the green state. The ears are 16 to 18 -rowed; an excellent sort for canning and for the late garden. Pkt., 10c; 1 lb., 35c; 2 lbs., $55 \mathrm{c} ; 5$ lbs., \$1.25, postpaid.

GOIDEN GIANT SWFET CORN-As good as Golden Bantan to eat and very much larger-That sentence will describe Golden and sweet olden Bantam is. Pkt., 10c; 1 lb., 40c; 2 bos. $75 \mathrm{c}$ 5 lbs., \$1.50, postpaid.

EARIY SURPRISE-A fine garden corn coming in very little later than Adams and with a much larger ear. Pkt., $10 \mathrm{c} ; 1$ lb., $25 \mathrm{c} ; 2$ lbs., $45 \mathrm{c}$, 49.

\section{COLLARDS}

One ounce will produce about 1,500 plants, or 150 feet of row. It produces a plant bearing a mass of leaves on the top of a stout stalk, and is a species of cabbage, and the flavor is the same. It is extensively used for the table, for winter greens, throughout the South. Sow the seed thickly in drills, in rich ground, transplanting when abut four inches high. In the South, seed may when abuut four inches high. In the South, seed may be sown

GFORGIA WHITE CABBAGr-Whiter and more tender than the Blue Stem. Introduced 15 years ago. Three-fourths of them bunch or head up in winter, weighing 10 pounds or more. Plants grow 30 to 40 .inches high and as much across. Pkt., 5c; 1 oz., 10c; 2 oz., $20 \mathrm{c} ; 1 / 4$ lb., $35 \mathrm{c} ; 1$ lb., $\$ 1.00$, postpaid.

SOUTHERN or GEORGIA-This variety is the old-time favorite. It stands all sorts of adverse conditions without injury and will make a good crop where the soil is too poor to grow cabbage, and it makes an excellent substitute for that vegetable. Is very hardy. Pkt., $5 \mathrm{c} ; 1$ oz., 10c; 2 oz., $15 \mathrm{c} ; 1 / 4$ lb., $75 \mathrm{c}$, postpaid.

NORTH CAROIINA-A decided improvement, - and has proved very popular wherever grown. Has short stem, large spreading leaves, very hardy, withstanding drouth in summer and cold in winter. Its cooking qualities are the best. Pkt., $5 \mathrm{c} ; 1$ oz., $10 \mathrm{c} ; 2$ oz., $15 \mathrm{c} ; 1 / 1 \mathrm{lb}, 25 \mathrm{c}$; 1 ib., $75 \mathrm{c}$, postpaid.

\section{POP CORN FOR SEED}

Pop Corn is a very profitable crop, yields well even in unfavorable weather and there is always a good market for it. Plant at the rate of 12 pounds to the acre, in drills 3 feet apart, dropping seed $11 / \%$ feet apart in the rows; or plant in hills, using 5 to 8 lbs. per acre. Cultivate the same as field corn.

QUEFN'S GOIDEN-The largest pop corn. The stalk grows 5 to 6 feet high and bears 2 to 3 large ears each. It is yellow; but pops perfectly white.

WHITE RICE-A very handsome and prolific white variety. The ears are 5 to 7 inches long. The kernels are long, pointed and somewhat resembling rice. This excellent, rather late maturing rariety vields heavily, and is considered the best pop corn for popping.

WHITE PEARI-This is a small grain variety, being a smaller kernel than the Queen's Golden or White Rice. It also has a small cob, but is a vers prolific variety and seems to do best in the southwest.

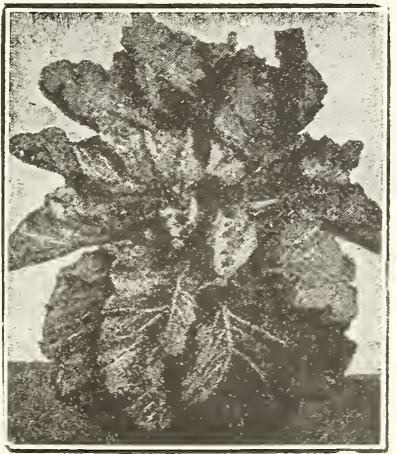
PRICES, above three kinds: Pkt., 10c; 1 lb., $30 \mathrm{c} ; 2$ lbs., $55 \mathrm{c} ; 5$ lbs., $\$ 1.10$ postpaid.

\section{KALE}

Sow from 2 to 3 pounds to the acre one ounce to 200 feet of drill. Makes excellent greens for spring and winter use. Sow in March or September in drills or broadcast.

DWARF GREFN CURIJD-This i the most popular variety grown, especially in the South. Pkt., $5 \mathrm{c} ; 1$ oz., $10 \mathrm{c}$ 2 oz., 15c; $1 / 4$ lb., $25 \mathrm{c}$; $11 \mathrm{lb}, 75 \mathrm{c}, 5$ lbs. TAII CURIED SCOTCF-A beauti ful curled tall growing variety. Also fine for spring planting. Pkt., $5 \mathrm{c}$; oz., $15 \mathrm{c}$ 2 oz., $25 \mathrm{c} ; 1 / 4$ lb., $40 \mathrm{c} ; 1$ lb., $\$ 1.25$ postpaid. 


\section{LETTUCE}

One ounce will produce 3,000 plants. For early use sow under glass in January or early February, and transplant as early as the ground can be put in good shape. Sowings may be made in open ground from April until Juiy and again at be made in open ground from April until Juiy and again at planted in rich, moist ground in rows 2 feet apart and plant 1 looc apart in the row.

SEIECTED BIG BOSTON-Our strain of this very popular variety is unsurpassed. Plants are large and vigorous Can be sown in the open ground in the spring or fall, or in frames for early spring planting, does particularly well in cold weather, and is especially recommended for fall planting in the South. Is very popular with gardeners and truckers. Plet. 5c; 1 oz., 20c: 2 oz., 35c; 1/ lb. 50c; 1 lb., $\$ 1.50$; 5 lbs., \$5.75, postpaid.

NEW YORK or WONDERFUI-This is the largest of all head lettuce, forming crisp heads often weighing two pounds. It matures slowly, first forming a conical head which becomes globular with maturity. It is of excellent quaiity, very sweet, and stands the hot weather well. Because of its size it must be given plenty of room between plants. This variety is known in some sections as Los Angeles. Pkt., 5c; oz., 25c 2 oz., 40c; 1/4 lb., 75c; 1 lb., $\$ 2.50$, postpaid.

ICFBERG-This is of the distinct crisp-head or cabbage-head type. It differs from all described above in having mid-rits which lend in, curving over the center, forming most tightly folded heads. One of the most delicious of the entire crisp-head class, becoming ready for use in from 80 to 85 days after sowing seeds. Pkt., $5 \mathrm{c}$; oz., 20c; 2 oz., $35 \mathrm{c} ; 1 / 4$ lb., $65 \mathrm{c} ; 1 \mathrm{lb}, \$ 2.00$, postpaid. PRIZFFEAD - Very popular, large, loose heading sort. Leaves finely crumpled and fringed, outer ones shaded brown; very crisp, sweet and tender, splendid for home garden. Plit., 5c; oz., 20c; 2 oz., 30c; 1/1 lb., $50 \mathrm{c}$; 1 lb., $\$ 1.50$, postpaid.

FANSON-The head is crisp and brittle and flavor excellent. Pkt., 5c; 1 oz., 20c; 2 ozs., $35 \mathrm{c} ; 1 / 11 \mathrm{~b} ., 50 \mathrm{c}$; 1 lb.. $\$ 1.25$, postpaid.

FUBBARD'S MARIKFT-An excellent heading riety for forcing or open ground; heads globular, very firm and well blanched; leaves broad, fairly blistered and crumpled, thick and stiff; color medium green; quality the best. Pkt., 5c; 1 oz., 20c; 2 oz., 35c; 1/ 1b., $50 \mathrm{c}$ : 1 lb., $\$ 1.25$, postpaid.

IIARDY WIITE COS-This is distinct from the ordi nary lettuce, and is much liked on account of its crisp. tender quality and delicate flavor; grows to very large size, producing long, pointed, compact bunches. Pkt., $5 \mathrm{c} ; 1$ oz., 20c; 2 oz., 35c; 1/1 1b., 60c, postpaid.

CAIIFORIA CREAM BUTTER-For autumn and winter use. Large head, which is very buttery, and of a rich-golden-yellow nisde.. Pkt., 5c; 1 oz., 20c; 2 oz., $35 \mathrm{c} ; 1 / 1$ lb., $65 \mathrm{c} ; 1$ lb., $\$ 1.85$, postpaid.

EARIX CURIED SIMPSON-This is the old favorite popular loose head variety, of dwarf, compact habit and quick growth. The curly leaves are large, yellowish green with finely curled edges. Very erisp ana tender. Matures early, quite hardy and withstands heat and drouth. Pkt., 5c; 1 oz., 20c; 2 oz., 35c; 1/4 lb., $50 \mathrm{c}$; 1 1b., \$1.25, postpaic.

AII SEASONS-Heads are large, solid and handsome, almost as large as Flat Dutch Cabbage; leaves are gray. This sort is a sure header and slow to run to seed. Pkt.

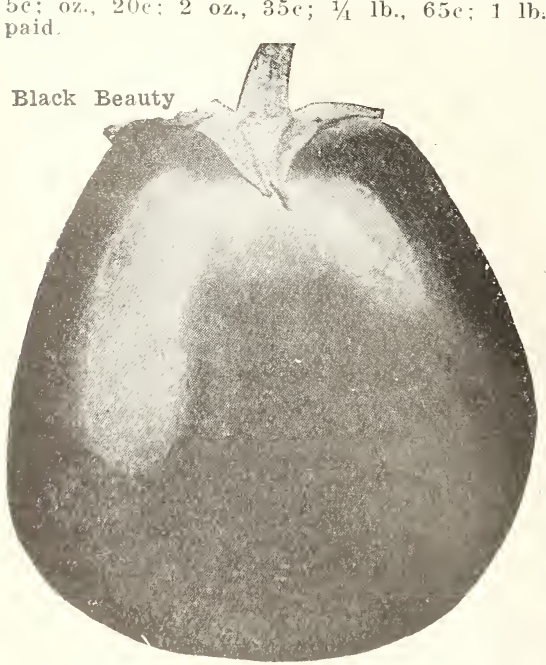

Big Boston

MIGNONETTE- Is small and bas tightly set leaves which makes a small extremely solid head.

$30 \mathrm{c} ; 2 \mathrm{oz}, 50 \mathrm{c} ; 1 / 1 \mathrm{lb}$, $90 \mathrm{c}$, postpaid.

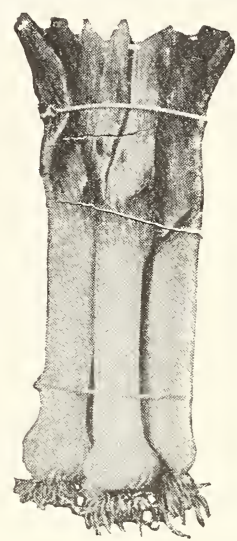

\section{LEEK}

One ounce will sow 100 feet of row. This belongs to the onion family, and is a good fall and win. ter substitute for green onions. The leaves are flat and the stems are very large, cylindrical and bulbous. Sow early in spring in drills 12 to 15 inches apart, covering $1 / 2$ inch deep, in good rich light soil. Thin plants to 6 inches apart in the row and draw the earth about them when cultivating.

IONDON FIAG - This well. known broad-leaved leek is hardy, productive, of good quality and is extensively cultivated in this country and is a favorite sort with the market gardeners and is also extensively used for the home garden. Pkt., 5c; 1 oz., 25c; 2 oz., $40 \mathrm{c} ; 1 / \mathrm{t}$ lb., $65 \mathrm{c} ; 1$ lb., $\$ 1.95$, postpaid.

\section{EGG PLANT}

One ounce will produce one to two thousand plants. Start the seed in hotbed early in March and when all danger from frost is over and the nights are warm transplant to open ground, allowing 3 feet space between the rows and 2 feet space between the plants in the row. The soil for Egg Plants cannot be too rich. Egg Plant seed requires a higher temperature for germination than any other garden vegetable and this temperature should be maintained right along in the hotbed in order to secure strong and healthy plants.

BIACK BFAUTY-Is 12 days earlier than New York; for northmors it is most desirable. In shape it is broad and thick; it is perfectly spineless and smooth; has beautiful, rich purple color and handsome lustre-very attractive and popular. Pkt., 5c; $1 / 2$ oz., $25 \mathrm{c} ; 1$ oz., $40 \mathrm{c} ; 1 / 1$ lb., $\$ 1.25 ; 1$ lb., $\$ 4.50$, postpaid. NaW YORI PURPII-An entirely spineless strain of the large ourple-fruited, well-known standard, and is a favorite. Our stock is extra selected from the best growers in New Jersey. Pl., 5c; 1/ oz., $25 \mathrm{c} ; 1$ oz., $40 \mathrm{c} ; 1 / 4$ lb., $\$ 1.25 ; 1$ lb., $\$ 4.00$, postpaid.

EARIY IONG PURPIE-One of the earliest and most productive sorts; fruits club shaped, 6 to 8 inches long; rich purple, fine quality. Pkt., 5c; 1/2 oz., 25c; 1 oz., 40c; $1 / 4$ lb., $\$ 1.25 ; 1$ lb., $\$ 4.50$, postpaid, 2NDIE Endive is grown in the same way as lettuce, but re - quires a longer time to develop. It takes about 50 days to grow a crop. Sow early in May in rows 15 inches apart and thin to $1 \mathrm{ft}$. apart in row. Endive should be blanched by tying up the outer leaves like celery when the plants are full grown. Draw up the soil about the plants. One ounce will sow 300 feet.

GRERN CURTED-Resembling a tuft of moss, and one of the best salads. Foliage finely cut; crisp, tender and fine flavor. Valuable salad plant for fall and winter use. Pkt., $5 \mathrm{c} ; 0 \mathrm{z} ., 15 \mathrm{c} ; 2$ oz., $25 \mathrm{c} ; 1 / 41 \mathrm{~b}$. $40 \mathrm{c} ; 1 \mathrm{lb} ., \$ 1.25$, postpaid.

BROAD IFAF BATAVIAN-This variety has rather smooth leaves, with thick, nearly white mid ribs. Inner leaves form a fair head whicl blanches creain white. Pkt., 5c; oz., 15c; 2 oz., $25 \mathrm{c} ; 1 / \mathrm{s} 1 \mathrm{~b} . .40 \mathrm{c}$ 1 lb., $\$ 1.25$, postpaid. 


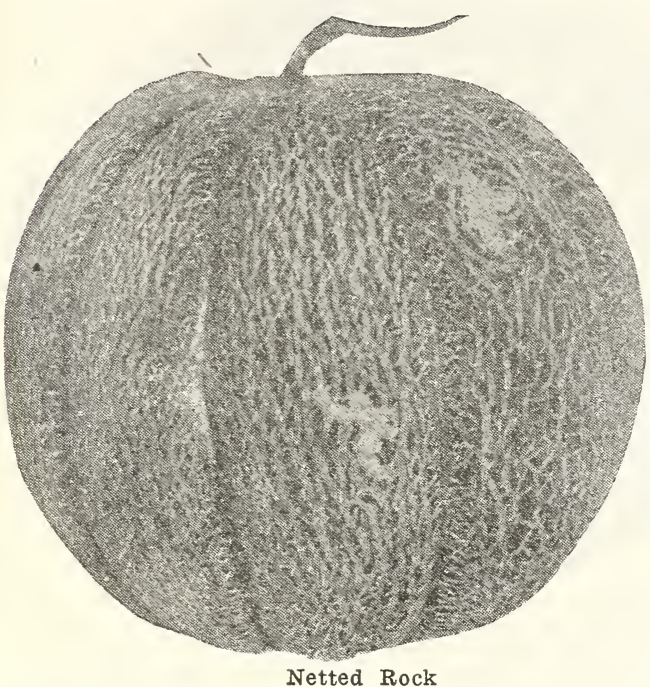

\section{MUSKMELON OR CANTALOUPE}

One ounce will plant about 50 hills; 2 pounds to the acre. Melons thrive best in a light, rich soil. Plant late in April or early in May, when ground has become warm and dry, hills about 5 feet apart each way. Previous to sowing seed mix a few shovelfuls of well-rotted manure in each hill, plant in each the most thrifty plants.

ROCIY FORD-This famous melon is known everywhere, and has been the standard shipping variety for several years. The melons are the true netted gem type, medium size, oval, very sweet and fine flavored; very prolific, and continues bearing enorinous quantities of fruit during the entire season. Our seed are grown for us at Rocky Ford, Colo., by an expert grower. The seeds are saved especially for seed purposes from selected melons. Pkt., 5c; oz., 15c;2 oz., 25c; $1 / 1 \mathrm{c} .40 \mathrm{c}$. 1 lb., $\$ 1.25 ; 5$ lbs., $\$ 5.50$, postpaid.

NETTED GFM-This has become one of the most popular of mall or crate melons. The vines are vigorous and popular of The fruits are oval, slightly ribbed, densely covered with fime netting. Flesh light green, tinged with yellow, very sweet and highly flavored. The fruit is very uniform in shape and quality and of fine size. Pkt., 5c; oz. $15 \mathrm{c}$; $25 \mathrm{c}$; 1 . Pkt., 5c; 0z., 15c; 2 oz., 25c; 1/. lb., $40 \mathrm{c}$ BAITIMORE OR ACME-A fine early, oblong, green fleshed variety, of good size; noticeably ribbed and hearily netted. Pkt., 5c; 1 oz., 15c; 2 oz., 25c; $1 / 1$ lb.. $3 \check{c}$ : 1 lb., $\$ 1.25$, postpaid.

\section{$\$ 1.25 ; 5$ lbs., $\$ 5.50$, postpaid.}

HONEY DEW MEION-The delicious honey-like fla vor of this new melon created a sensation wherever used last year. The fruit is of good size, weighing 6 to 8 pounds: light cream colored, smooth skin with thick, rich and sweet flesh of light green color. The rind is thin but tough and so close that the rich flesh is practically sealed up where it keeps in finest condition for sereral months after it is ripe. Pkt., 10c; 1 oz., 20c; 2 oz.; $35 \mathrm{c} ; 1 / 4$ lb., $60 \mathrm{c} ; 1$ lb., $\$ 2.25$, postpaid.

PROIIFIC NETTED NUTMFG-This splendid melon is one of the very best varieties for either home use or the market. It has a very small seed cavity, deep green flesh and is of very uniform shape, average about 5 inches. Pkt., $5 \mathrm{c}, 1$ oz $15 \mathrm{c}$. 1 lb., \$1.25, postpaid.

OSAGE or MIIIER'S CREAMI-A favorite salmon Heshed variety. Large oval, slightly ribbed and satted; skin is very dark green; flesh is very thick and sweet flavored, most delicious to the rind. The whole crop is very even and fruit extra heavy, owing to this thickness of the flesh. A great favorite for both market purposes and the home garden especially. Pkt., $5 \mathrm{c}$; oz. $15 \mathrm{c}$ 2 oz., $25 \mathrm{c}$; 1/4 lb., 40c; 1 lb., $\$ 1.25$, postpaid.

BANANA-Shaped somewhat as name indicates; grows about $2 \frac{1}{2}$ feet long; flesh deep salmon colored and of only fair quality. Pkt., 5c; 1 oz., 20c; 2 oz., $35 \mathrm{c}$; $1 / 1$ lb., 50c; 1 lb., $\$ 1.75$, postpaid.

NEW MUSIMFIION POIIOCK, 10-25-Salmon tint. The most popular of the Rocky Ford Type Melons among the western commercial growers. Introduced about two years ago, the stock has been controlled until now by a few shippers. Very uniform in highest quality; vigorous and early. Cuts with a golden center shading to a green at the rind. The latest and best Rocky Ford. Pkt., 5c; oz., 15c; 2 oz., $25 \mathrm{c} ; 1 / 1$ lb., $40 \mathrm{c} ; 1$ lb., $\$ 1.25$, postpaid.

lars, in sheds, in hotbeds, or sometimes in open air. Fermenting horse manure at a temperature of about 70 degrees, mixed with equal weight of fresh sod loam, made into beds the size required, 8 inches deep. In this coveriant the broken pieces of spawn, 6 inches apart, tect tect from cold and rain.- Per brick, $40 \mathrm{c} ; 5$ bricks, $\$ 1.75$, parcel

\section{HORSE RADISH Horse Radish rarely produces seed, but} the home is grown from pieces of the root. For e set wherever a few feet of space is availas a crop they should be set in rich, moise, wellthe row. root 1 . Set the roots vertically, small end down, and the top of the root 1 to 3 inches below the surface of the ground. Cultivate thoroughly until the tops cover the ground, when their shade will keep down the weeds. The standard market variety. Doz., 50c; per $100, \$ 2.75$, postpaid. By express, doz., $40 \mathrm{c} ; 100$ for $\$ 2.50$.

1USTARD One ounce will sow about 80 feet of drill. For at intervals early salad sow in February and for general crop thick in rows.

EIEPFANT EAR-This is a splendid variety for the market gardeners and amateurs, and will surely give satis. faction wherever planted. The leaves are sinothe satis. large, and always tender and plant. Pkt., 5c; 1 oz., 15c;2 oz., 20c; 1/ 1b., $30 \mathrm{c} ; 1$ lb., \$1.00, postpaid.

CHINESE MAMMOTH-A European variety, with light green very large leaves. It has not the same taste as the large-leaved or the large curled, but will stand longer before going to seed. Pkt., 5c: 1 oz, 10c; 2 oz. $15 \mathrm{c} ; 1 / 4$ lb., $25 \mathrm{c} ; 1$ lb., $75 \mathrm{c} ; 5$ lbs. $\$ 3.25$, postpaid.

SOUTHRRN GIANT CURIED-Leaves are large, light green with yellowish tinge, much crimped and frilled at the edges. Very succulent, pungent and of sweet flavor. Pkt., 5c; oz., 10c; 2 oz., 15c; 1/4 lb., 25c; $11 \mathrm{lb} ., 75 \mathrm{c}$

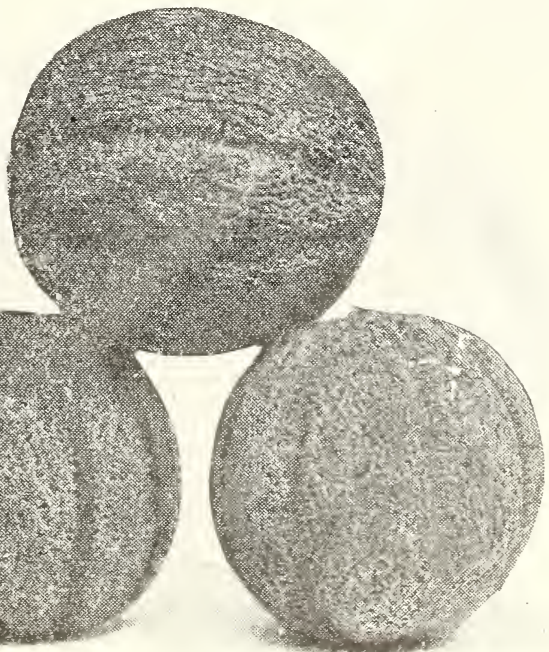

Rocky Ford 


\section{Watermelons}

An ounce will plant 40 hills; 2 to 3 pounds will plant an acre. Watermelons delight in a light sandy soil. Plant when danger from frost is over, in hills 8 to 10 feet apart each way. Put from 10 to 15 seeds in each hill and when well started thin out to the two best plants. In this latitude we plant the seed about the middle of Anril. The bugs will require careful watching or they will eat up the plants before they get started. Do not make a big "hill" when sowing the seed; it is much better to have the "hills" Jevel with the surface of the ground.

SEIFCTED TOM WATSON-This is an extra selected stock of this splendid well-known and popular melon. Seed is saved only from specimen made as near uniform as possible. The grower will no doubt appreciate this from the fact that this stock will grow larger and more regular melons than the ordinary strain. We are pleased to offer this special stock this season, as we are sure you will be highly pleased with the results. Pkt., $5 \mathrm{c} ; 1 \mathrm{oz} ., 15 \mathrm{c} ; 2 \mathrm{oz}$, $25 \mathrm{c} ; 1 / 4$ lb., $40 \mathrm{c} ; 1$ lb., $\$ 1.25 ; 5$ lbs., $\$ 5.50$, postpaid. TOII WATSON-Shape long, color of rind dark green, which is thin but very firm, making it a fine shipper.'. Flesh is bright red, firm and very sweet; has taken the lead over all other shipping melons, Pkt, 5c; 1 oz., 10c; 2 oz., 15c; 1/4 lb., 30c; $11 \mathrm{~b}$, $85 \mathrm{c} ; 5$ lbs., $\$ 3.00$, postpaid.

"IRISH GRAY" WATERMPION-The size of this nielon is uniformly large and it closely resembles Kleck ley's Sweets except the color, which is a yellowish gray. Flesh is very sweet and firm, without hard center, brilliant sparkling red. Rind almost as tough as a citron making a grand shipper. Earlier than Tom Watson. Irish Gray has instantly met with universal favor. Pkt. $5 \mathrm{c} ;$ oz., $15 \mathrm{c} ; 2$ oz., $25 \mathrm{c} ; 1 / 4$ lb., $35 \mathrm{c} ; 1$ lb., $\$ 1.25 ; 5$ lbs., $\$ 5.75$, postpaid.

KIECKIEY'S SWEFT-This variety ripens early and is considered by many the sweetest, juiciest and most delicious of all. Specially fine for the home garden. The skin is dark green, faintly striped. Flesh bright red and peculiarly sweet, rich, crisp and of pleasing flavor. Pkt., 5c; 0z., 10c; 2 oz., 15c; 1/4 lb., 30c; 1 lb., $\$ 1.00 ; 5$ lbs., \$3.75, postpaid.

HAIBERT HONEY-The melons average eighteen to twenty inches long and are full or bluntly rounded at both ends. The skin is a dark, glossy green. The flesh is a beautiful crimson, the rich coloring and luscious quality extending to the thin rind. Pkt., $5 \mathrm{c} ; \mathrm{oz}_{\text {, }} 15 \mathrm{c}$; 2 oz., 25c; 1/4 lb., 40c; 1 lb., $\$ 1.25$, postpaid.

GFORGIA RATPIFSNAKF-The old standard variety, large oblong, striped; flesh of fine quality. Pkt. $5 \mathrm{c} ;$ oz., 10c; 2 oz., 15c; 1/4 lb., 25c; 1 lb., $85 \mathrm{c} ; 5$ lbs., $\$ 3.00$, postpaid.

BIACK DIAIMOND-Immense in size, the common weight of this melon is from sixty to eighty pounds. The rind hard and firm, which makes it superior for long distance shipping. In shape it is nearly round. Color solid dark green. Flesh deep red and fine quality. Pkt., $5 \mathrm{c}$; oz., $10 \mathrm{c} ; 2$ oz., $15 \mathrm{c}$; 1/4 1b., $25 \mathrm{c} ; 1$ lb., $85 \mathrm{c}$, postpaid. SWFPT HART-Popular for market. Large heavy fruits of oval or round form; skin very pale green, with distinct netted lines of a slightly darker shade. The melons bear shipping well. The solid flesh is a deep red. Pkt., 5c; 1 oz., $10 \mathrm{c} ; 2$ oz., 15c; $1 / 1$ lb., $25 \mathrm{c} ; 1$ $1 b ., 75 \mathrm{c}$, postpaid

GÖLIN HONBY-Flesh bright golden yellow, skin beautiful green, shape slightly elongated. No melon is

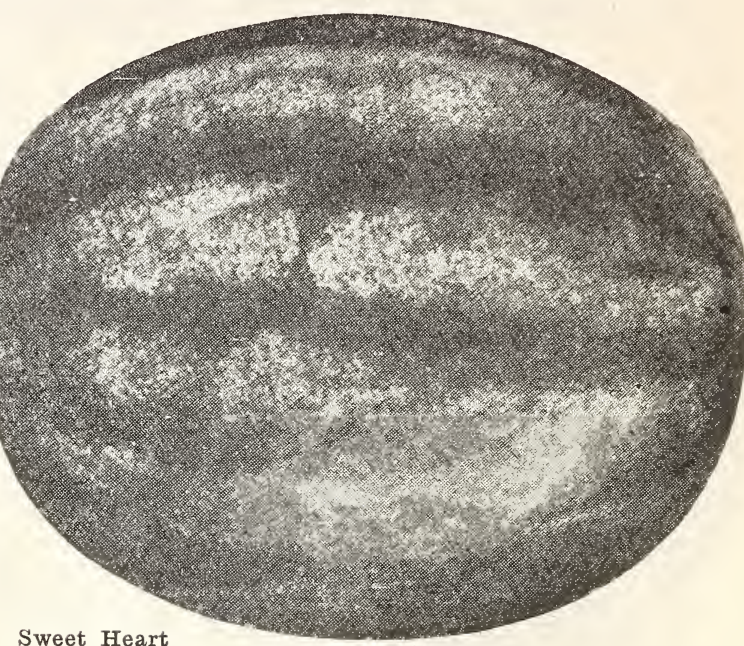

as sweet and delicious. Pkt., 5c; 1 oz., 15c; 2 oz. $20 \mathrm{c}$ $1 / 1$ 1b., 35c; 1 lb., $\$ 1.00$, postpaid.

HARRIS' FARIIEST-Extra early; fruits large, slightly oval, with irregular, mottled, broad stripes of light and dark green; flesh bright red, sweet and tender.

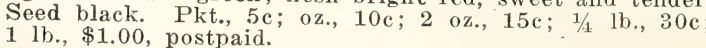

\section{OKRA}

One ounce to 100 foot row. Extensively grown in the South, and should be better known, as it is a delicious vegetable. The young green pods make a healthful and delicious soup and, when picked, are a fine salad. Sow after the weather has become warm in rows 3 feet apart, 2 feet apart in the rows. Will succeed in any good garden soil.

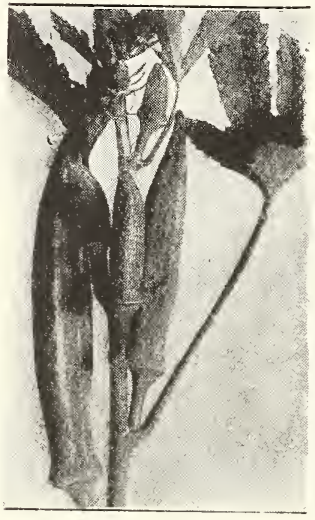

WHITE VמURT - Bears round, white, smooth pods, unlike other varieties, which are ridged or square-edged. Pods are large and are produced in great abundance. The market gardeners' favorite. Pkt., $5 \mathrm{c} ; 1 \mathrm{oz}$, $10 \mathrm{c} ; 2$ oz., 15c; 1/4 lb., 25c; 1 lb., $65 \mathrm{c} ; 5$ lbs., $\$ 2.85 ;$ postpaid. P E R KI'S MA M M T T IONG POD-This variety is about three feet high, very early and productive. Pods deep green, very long, slender, slightly corrugated, very tender and of good quality. Pkt., 5c; oz., 10c; 2 postpaid.

EARIY DWARF GRFENOf dwarf growth but immensely productive. The pods are tender, of best quality, and are borne throughout the season. Pkt., 5c; 1 oz., 10c; 2 oz., $15 \mathrm{c}$; $1 / 4$ lb., 25c; 1 lb., $65 \mathrm{c} ; 5$ lbs.
$\$ 2.85$, postpaid.

Okra

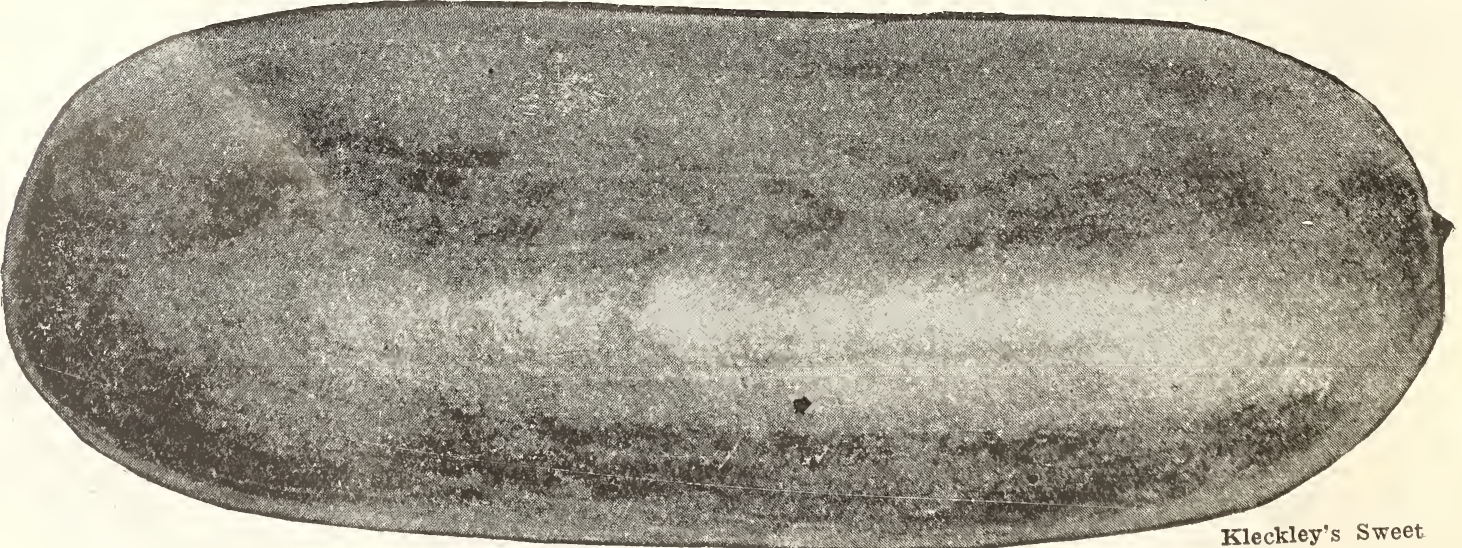




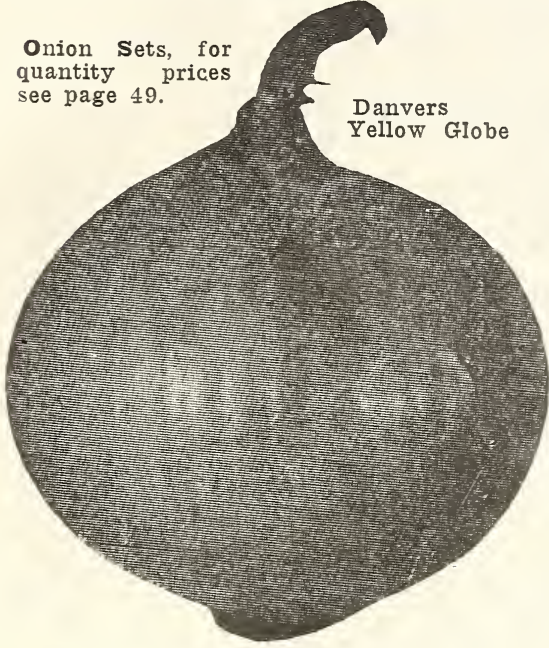

ONION SETS Plant the sets four inches apart in rows (and oot between the rows, but do not cover the sets entirely. This applies to all varieties except the Potato Onion, which should be planted in rows 15 inches apart and 9 inches apart in rows and then cover with about one inch of soil. A!1 varieties can be set out in the fall as well as in the spring. Fall plantwell in the South and should be well in the South and
more generally practiced. WHITE SIIVERSKIN-1 Tt $25 c \cdot 4$ ats $85 \mathrm{c}$ postpaid RED W $\mathbf{E}$ T $\mathbf{T} \mathbf{E} \mathbf{R} \mathbf{S}$ FIEID-1 qt., $25 \mathrm{c}$; qts., $85 \mathrm{c}$, postpaid. YEIIOW DANVERS -1 qt., $20 \mathrm{c} ; 4$ qts., $75 \mathrm{c}$ postpaid.

YELIOW POTATO1 qt., $40 \mathrm{c} ; 4$ qts., $\$ 1.25$, postpaid.

WHITE MUITIPIIFR STTS-1 qt $40 \mathrm{c}$ 4 qts., $\$ 1.25$, postpaid.

\section{PARSLEY}

One ounce will sow 150 feet of drill. Sow early in the spring in drills a foot apart. The seed germinates slowly, often 2 or 3 weeks will elapse before the plants will make their appearance. Often fails entirely in dry weather. Thin to 6 or 8 inches keep the soil loose.

IARGE DOUBLE CURLED-This is an excellent variety, dwarf in habit; grows very compactly and stands the winter better than the plain. Leaves crimped or curled and used principally as a garnish for the table. Pkt., 5c; 0z., 10c; 2 oz, $15 \mathrm{c} ; 1 / 4$ lb., 25c; 1 lb., $75 \mathrm{c} ; 5 \mathrm{lbs}$. $\$ 3.50$, postpaid.

PIAIN OR SINGIE-Dark color; very hardy; much used for flavoring. The leaves are plain or smooth. Fkt., $5 c$ oz., 10c; 2 oz., 15c; 1/t lb., 30c; 1 lb., 90c, postpaid.

\section{PARSNIPS}

One ounce will sow 200 feet of drill; 5 pounds required for one acre. Like all root crops, they do best on a deep, rich, sandy soil, but will make good roots on any soil that is deep and mellow. In drills 2 to $21 /$ feet apart; cover with $1 / 2$ inch soil and press the seed down firmly. Thin the plants to 5 or 6 to the foot; cultivate frequently during the summer to insure rapid growth. In fall the roots may be taken up and stored in root cellars or pits for winter use.

SUGAR or HOLIOW CROWN-Pkt., $5 \mathrm{c}$; oz $20 \mathrm{c} ; 2$ oz., $35 \mathrm{c}$; $1 / 1$ lb., $45 \mathrm{c} ; 1$ lb., $\$ 1.25$, ppd.

\section{ONIONS}

No vegetable is so widely grown as the onion and it deserves a place in every garden. Every year the acreage devoted to onions is increased and still the demand contimes to exceed the suppy. Crop failures are so rare that you can savely plant large tracts of ground in onions.

One ounce will sow 100 feet of drill; 6 pounds will plant 1 acre. A deep, rich soil, thoroughly worked is best for this crop. For large, fancy onions, sow in January or February, it hotbeds or trays. As soon as the weather opens and the sets are the size of a goose quill plant in rows 12 inches apart and 4 to 6 inches between the onions. For main crop, sow in the open ground in March and April in drills 12 inches apart, thinning out afterwards to 3 or 4 inches apart.

SOUTHPORT RED GIOBE-The finest type and most popular of the red onions. The bulbs are distinctly globe-shaped, with small neck, and are excellent keepers; color a deep purplish red. Pkt., 5c: 1 oz., 30c; 2 oz., 50c; 1/4 lb., 85c; 1 lb., $\$ 2.75$, postpaid.

LARGE RED WETHERSFIEID-A fine, large, rather flat sort, of a deep purplish-red color; noted for its productiveness and keep ng qualities. Pkt., $5 \mathrm{c} ; 1$ oz., $25 \mathrm{c} ; 2$ oz., $40 \mathrm{c} ; 1 / 41 \mathrm{~b} ., 75 \mathrm{c} ; 1 \mathrm{lb}$.
$\$ 2.25$, postpaid.

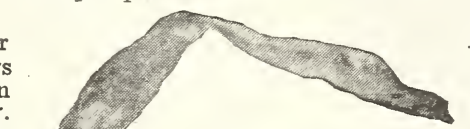

AN ONION OF HIGH QUALITY
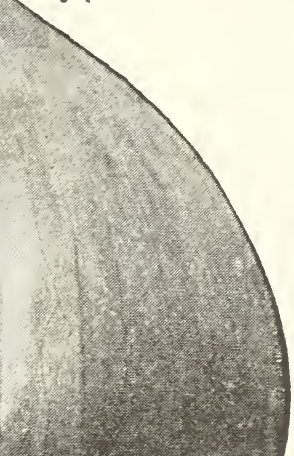

RED BERIMUDA-In shape and size, also in flavor, exactly only in color, which is pale reâ. Pkt., 5c; 1 oz., 25c; 2 oz., $40 \mathrm{c}$; $1 / 4$ lb., $75 \mathrm{c} ; 1$ lb., $\$ 2.50$, postpaid.

PRIZETAKER-One of the largest onions grown and the mildest; is productive and a sure cropper; bulbs are globeshaped and of light straw color. Pkt., 5c; 1 oz., $25 \mathrm{c} ; 2$ oz., $45 \mathrm{c}$; $1 / 4$ lb., $75 \mathrm{c} ; 1$ lb., $\$ 2.50$, postpaid.

YEILOW GIOBE DAN VERS - Bulbs medium to large size, uniformly globe shaped; skin rich coppery yellow; flesh creamy white, crisp and mild. Pkt., 5c: oz., $25 \mathrm{c}$; $\$ 2.50$, postpaid.

\section{SOUTH P R T WHITE} GIOBE-One of the best of the Globe varieties. Large in size, fine in quality, bringing a ready sale anywhere. Color a ready sale anywhere. Color
a silvery white. When sown a silvery white. When sown green or bunch onions. Our strain of this seed is of a fine quality. Pkt., 5c; 1 oz., $30 \mathrm{c}$; 2 oz., 50c; 1/4 lb., 85c; 1 lb, $\$ 2.85$, postpaid.

CRYSTAT WHITE WAXEarliest of the Bermuda varieties; makes large, flat onions so mild and sweet that they can be eaten like apples. Pkt., $5 \mathrm{c}$; 1 oz., 40c; 2 oz., $65 \mathrm{c} ; 1 / 4$ lb., $\$ 1.25 ; 1$ lb., $\$ 4.00$, postpaid.
WrITE SIVVR SKIN-This is a superior stock. Its delicate, mild flavor, stately form, large handsome size, pure white color make it a most wonderful variety for the table, the most profit. able for market and shipping. Plants are of an able for market and shipping. Plants are of an
extremely thin neck and sure to ripen early; should be harvested as soon as ripened and aried in the shade to preserve their silvery white skin. Plkt. $5 \mathrm{c} ;$ oz., $30 \mathrm{c} ; 2$ oz., $50 \mathrm{c} ; 1 / 4$ lb., $85 \mathrm{c} ; 1$ lb., $\$ 2.85$. postpaid. 


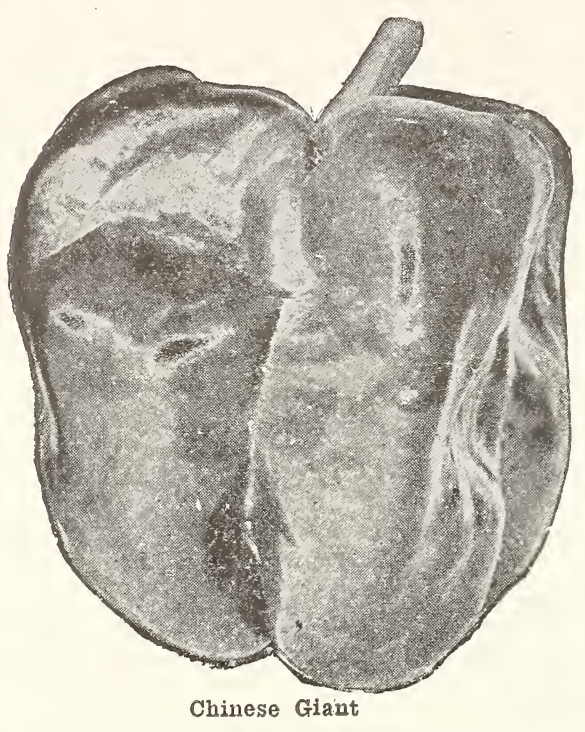

PUMPKINS

One ounce will plant about 25 hills, 5 pounds to the acre.

The pumpkin under good care bears abundantly, and furnishes a great amount of palatable food for cows, pigs, etc. Several of the finest flesh varieties are also used for culinary purposes. They may be grown as a field crop. Plant in hills 8 feet apart eacl way, and any time after the first of May. Avoid planting near other vine crops, as they will hybridize, and damage that crop.

KENTUCKY FIEID-A very popular Southern sort, large and flattened. A wonderful keeper. A good stock variety: also a valuable eating and pie sort. Pkt., 5c; oz., 10c: 2 oz., $15 \mathrm{c}$; postpaid.

STRIPED CUSHAW-This pumpkin is of the crookneck type with mottled green and white stripes. The neck is rather small. Fruit often attains a weight of 15 pounds; flesh is yellow, very solid and fine-grained. An excel lent variety for culinary purposes. Pkt. $5 \mathrm{c} ; 1$ oz., 15c; 2 oz., 25c; $1 / 4$ lb., $40 \mathrm{c}$; 1 lb., \$1.25, postpaid.

KING OF MAMMOTH-The giant among pumpkins: specimens have been grown to weigh 250 pounds and reaching 2 feet or more in diameter Fruits are almost round, skin orange-colored and slightly rough. Flesh deep and yellow, quality excellent. A fine variety to plant where only a few hills ara wanted. Pkt., 5c; 1 oz., 15c; 2 oz., $25 \mathrm{c}$; $1 / 1$ lb., $50 \mathrm{c} ; 1$ lb., $\$ 1.50$, postpaid.

TENNESSEE SWEET POTATO Of medium size, creamy white, with light green stripes and fine grained brittle flesh. Pkt. $5 \mathrm{c}$. oz., 15c; 2 oz., $25 \mathrm{c}$; $1 \mathrm{~b} ., 35 \mathrm{c}$; $1 \mathrm{~b}$. $\$ 1.25$, parcel post paid.

JAPAIESE PIE-Shaped somewhat like the Cushaws and grows to a lare size, skin deep green with dark stripes and rough ridges on the neck; flesh deep yellow and of the highest quality; seeds sculptured like Chinese letter's. This is one of the best varieties to plant for home use. Plkt., 5c: 1 \%., $15 \mathrm{c} ; 2$ oz., $25 \mathrm{c} ; 1 / 4$ 1b., $40 \mathrm{c} ; 1$ lb., $\$ 1.25$ postpaid.

See pages 45,46 and 47 for a complete list of Poultry Supplies of all kinds.

\section{PEPPERS}

One ounce will produce about 1,000 plants.- Sow in hotbed in March and transplant to the open ground as soon as the weather is warm and settled. Set in 3-foot rows and about 2 feet apart. Cultivate well and keep free from weeds.

CRIMSON GIANT-An early maturing large sized sweet pepper, similar in shape to Chinese Giant, but much longer, and flesh thicker. It is exceptionally mild and very prolific; earlier than the Chinese Giant. Pkt., 5c; $1 / 4$ oz., $30 \mathrm{c} ; 1$ oz., $50 \mathrm{c} ; 2$ oz., $85 \mathrm{c} ; 1 / 1$ lb., $\$ 1.50 ; 1$ lb., $\$ 5.50$, postpadi.

BELI or BUII NOSE-The plants are vigorous, about two feet high, compact and very productive, ripening their crop uniformly and early. The fruits are large, with thick mild flesh of excellent quality for use in salads and mangoes or in stuffed peppers. The color is deep green when fruit is young, bright crimson when ripe. Pkt. $5 \mathrm{c} ; 1 / 2$ oz., $20 \mathrm{c} ; 1$ oz., $35 \mathrm{c} ; 2$ oz., $60 \mathrm{c} ; 1 / 1$ lb., $\$ 1.00 ; 1$ lb., $\$ 3.85$, postpaid.

RUBY IING-A large sort, $4 \frac{1}{2}$ to 6 inches long, and $3 \frac{1}{2}$ to 4 inches thick. Color a ruby red at maturity; excellent quality. Among the best sorts for pickling. Used for stuffing. Pkt., $5 \mathrm{c}$ $1 / 2$ oz., $20 \mathrm{c} ; 1$ oz., $35 \mathrm{c} ; 2$ oz., $50 \mathrm{c} ; 1 / 41 \mathrm{~b} ., 90 \mathrm{c} ; 1$ lb., $\$ 3.50$, postpaid. CHINESE GIANT-Plant dwarf, fruit of mammoth size, very broad but rather short. It is very late and a rather shy yielder Popular on account of its large size and mild flavor. Pkt., 5c; 1/ oz., $25 \mathrm{c} ; 1$ oz., $45 \mathrm{c} ; 2$ oz., $80 \mathrm{c} ; 1 / 1$ lb., $\$ 1.50 ; 1$ lb., $\$ 5.00$, postpaid. PIMENTO or PERFECTION-This is the sweetest pepper grown, as it does not contain the slightest trace of fieryness. The plants are extremely productive, and peppers are medium in size and of a shape which is desirable for filling, and when prepared in this man

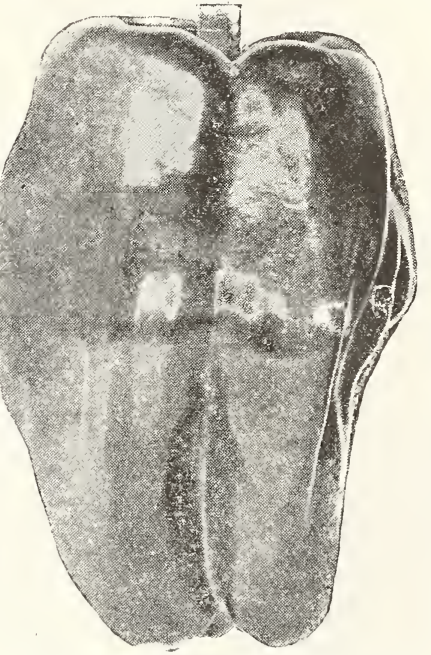

RUY KING One of our most opular pickling varieties and uch in demand by small garner they are delicious. It may be used in preparing salads and for flavoring. in which case it will add a fresh and delightful flavor. The flesh is quite delightful flavor. The flesh is quite for peeling the skin off. When fully ripe the peppers are of a brilliant red color and very attractive. Pkt., $5 \mathrm{c}$ $1 / 20 \mathrm{z}, 20 \mathrm{c}, 1 \mathrm{oz}, 35 \mathrm{c} ; 20 \mathrm{z}, 60 \mathrm{c} ; 1 / 4$ Ib., $\$ 1.00 ; 1$ lb., $\$ 3.50$, postpaid.

IONG RED CAYENNE-The well known favorite hot pepper, fruits con ical shaped 3 to 4 inches long of bright red color, and are borne in great profusion. Very prolific for so large a pepper. Matures in about 125 days. Pkt., 5c; 1/2 oz., 25c; 1 oz., 35c; 2 oz., $60 \mathrm{c} ; 1 / 4$ lb., $\$ 1.00 ; 1$ lb., $\$ 3.50$, postpaid BIRD'S FYE, or CREOIE-Very hot; used for pepper vinegar. Pkt., $10 \mathrm{c}$ oz., $50 \mathrm{c} ; 2$ oz., $90 \mathrm{c} ; 1 / 4$ lb., $\$ 1.75$.

TOBASCO-Very pungent and strong. Pkt., 10c; oz., 50c; 2 oz., $90 \mathrm{c} ; 1 / 4 \mathrm{lb}$. $\$ 1.75$.

RED CHIII_Small and very pungen used for chili sauces. Pkt., 10c; 1 oz., $35 \mathrm{c} ; 1$ oz., 50c; 2 oz., $90 \mathrm{c} ; 1 / 4 \mathrm{lb}$. $\$ 1.75$, postpaid.

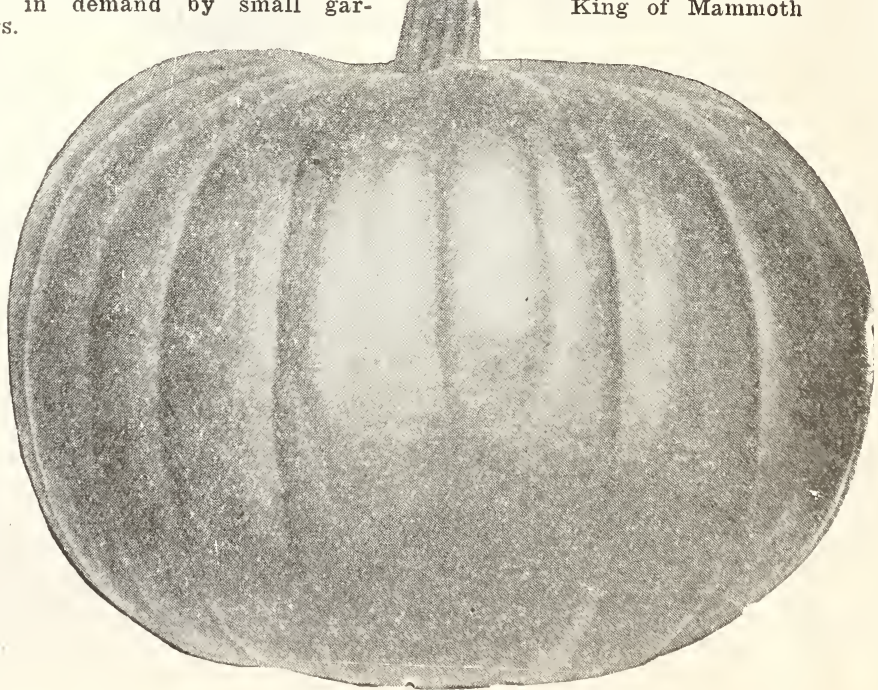




\section{GARDEN PEAS}

One pound to 125 foot row; one acre requires about 100 pounds

Peas are safe to sow as early as the ground can be worked. They do well in cool weather. Select a light, not too rich soil, or they will run to vine too much. Sow double rows, these to be 6 inches apart and $21 / 2$ to $3 \frac{1}{2}$ feet between the double rows, and drop the peas every 3 inches and covering $2 \frac{1}{2}$ inches.

The wrinkled sorts marked (*) are more sensitive to cold and should never be planted before March 1 .

AMIRICAN WONDER-The earliest of the dwarf winkled orous and productive, with dark, luxuriant foliage. Vines dwarf, 12 inches high, of compact growth. Pods $2 \frac{1}{2}$ inches long, round, appearing almost square, and crowded to the end with peas of excellent quality. Pkt., $10 \mathrm{c}$ $1 / 2$ lb., 20c; 1 lb., $40 \mathrm{c}$; 2 lbs., $70 \mathrm{c} ; 5$ lbs., $\$ 1.60$, postpaid.

AIASIRA-This is the earliest of all small podded peas. Universally used for first planting; the vines are a distinctive light green, and from 2 to 3 feet high. Pods are dark green, about $2 \frac{1}{2}$ inches long, straight and well filled with small, smooth blue-green peas of excellent flavor. This about 60 days to mature. Pkt., 10c; $1 / 2$ 1b., 20c; 1 bardeners. Requires 5 lbs., $\$ 1.60$, postpaid.

THE AMEER, or IARGE AIASKA-Very popular with truckers in certain sections of the South. The peas are smooth and therefore can be planted early without rotting. The season is early, 2 or 3 days later than Alaska, and the pods are almost twice as large Pkt. $10 c$. $20 \mathrm{c} ; 1$ lb., 40c; 2 lbs., 75c; 5 lbs., $\$ 1.65$, postpaid.

FIRST AND BEST-This is the earliest and most even strain of white, extra early peas, maturing so well together that sometimes a single picking will secure the entire crop. Pkt. 10c; 1/ $1 \mathrm{~b}, 20 \mathrm{c} ; 1 \mathrm{~b}, 40 \mathrm{c} ; \mathrm{l}$ roc; j lbs., $\$ 1.60$, postpaid.

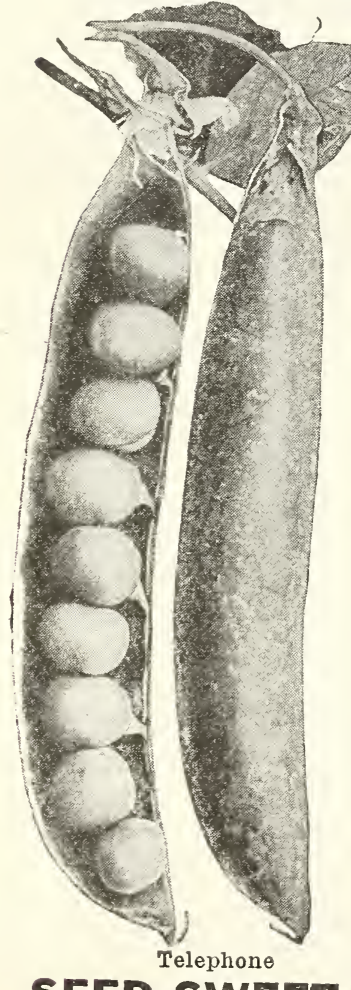

SEED SWEET POTATOES

All Sweet Potatoes will be shipped about the middle of March. The weather before that time is entirely too cold to ship. We ship in good condition, and do all in our power to get them to you in good order. Sweet Potatoes are them to you Our responsibility ceases upon our delivery to the railroad company. We will not be responsible for delays or damaged conditions on arrival

NANCY FALI-Skin yellow; meat, which is clear amber color; is as sweet as honer.

PORTO RICO YAIV-Skin is golden color, with a slight pinkish tinge. Meat deep orange yellow, soft and sweet; tubers long and smooth; a very desirable shape.

For prices on Sweet Potatoes see price list rage 49 . 1.65 , postpaid. 1.65, postpaid.
PRAS or PROSPERITY (W rinkled) vation. The peas are tender and sweet, of long and contain from eight to ten $/ 2$ inches entormous and excellent quality. Pkt.,

ral crop. The A large podded pea for genrowth and average 18 to 20 very strong in liciors in the pod, and of a most deIAXTON PEAS-Popular early The seed is wrinkled, to end with plump peas. Vines grow from 3 to $31 / 2$ feet high. sorts, in which the (Edible Pods)-We consider this the best of the edible-podded as snap beans. The pods of Melting Sugar are very and are cooked in the same way

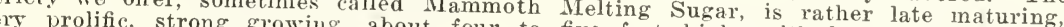
XTONIAN-The largest podded varity

(a) classed crop does not mature until a few days later it only grows about 18 inches.

(Not Wrinkled)-A very tall, vigorous growing the heat and cold than any other good quality. This variety is very hardy, los., $\$ 1.50$, postpaid.

of the best flavored INGLAND-A very productive standard main crop variety, one is medium green. The vines are 4 to 5 feet high, and the foliage about 3 inches long. Pkt., 10c; 1 ; about 3 inches long. Pkt., 10c; $1 / 2$ lb., $20 \mathrm{c} ; 1$ lb., $40 \mathrm{c} ; 2$ lbs., $70 \mathrm{c} ; 5$ lbs., $\$ 1.60$,
postzaid

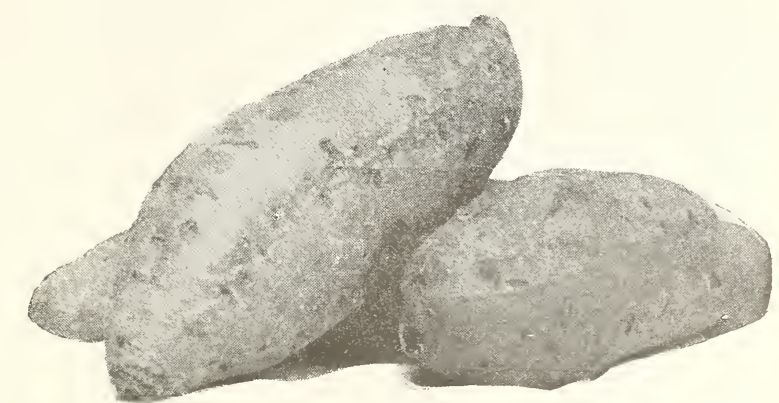

Nancy Hall 


\section{Seed Potatoes}

One peck will plant 125 feet of row; 8 to 10 busheis will plant 1 acre. The land should be gotten into fine mellow condition. Mark it off into rows 3 feet apart and run a furrower along so as to make a furrow about four inches deep. Apply Truck Fertilizer along this furrow with a distributor or by hand. The furrower should be run along $2 \frac{1 / 2}{2}$ inches deep, after the fertilizer is applied, to mix it with the soil. Drop the seed 15 inches apart and cover with a cultivator arranged to throw the earth back into the furrow. Cultivate frequently after the potatoes come up, and do not "hill up" more than just enough to cover the potatoes which form near the surface. If there is danger of frost soon after the potatoes come up, they may be covered with earth without injuring them at all.

EARIY RED TRIUMPF-Extremely prolific and extra early, the color a beautiful light red; medium size. Growth very uniform, nearly round. Flesh white; mealy when cooked. Eyes slightly depressed, skin smooth. Its beauty, quality, extreme earliness and great productiveness make it very profitable.

EARIY ROSF-One of the oldest varieties and still largely used. Many growers claim it has never been surpassed in quality and productiveness. Potatoes are oblong, light pink color and of the finest flavor.

IRIST COBBIER-This is one of the most réliable, and is fast becoming one of the most popular of the early varieties for a white skin potato in the South. It is of a handsome cream-white color and of excellent quality, making it most desirable for the best trade. It is a vigorous grower, ripens uniforml and is a good keeper. In fact it is one of the best all-around early potatoes now on the market.

FARIY OIIO-This is one of the standard varieties, and is credited with being the very earliest potato on the market. It matures a week earlier than the Early Rose. The tuhers averag large in size, are oval, oblong and round at seed end. A fine yielder, but does best for planting in loamy or stiff soils. Irish Cobbler seems to do best in light or sandy soils.

IOOKOUT MOUNTAIN-Very prolific, late; long keeping variety, for planting in June and July; grows large tubers, pure white smooth, of good quality. No other variety stands our hot climate as well. We book or ders now for shipment in June. Prices on application.

For prices on Irish Potatoes see Prices on

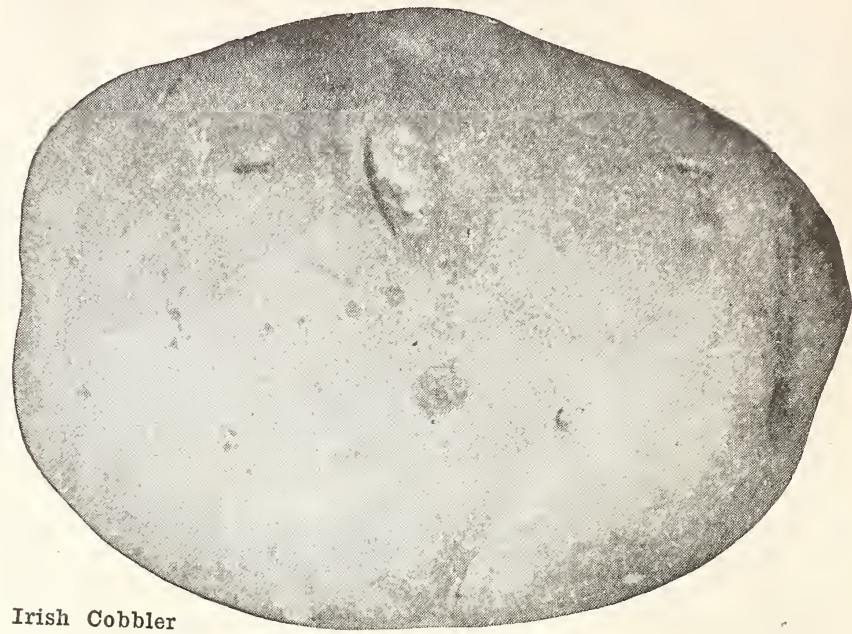

\section{Popular Radishes}

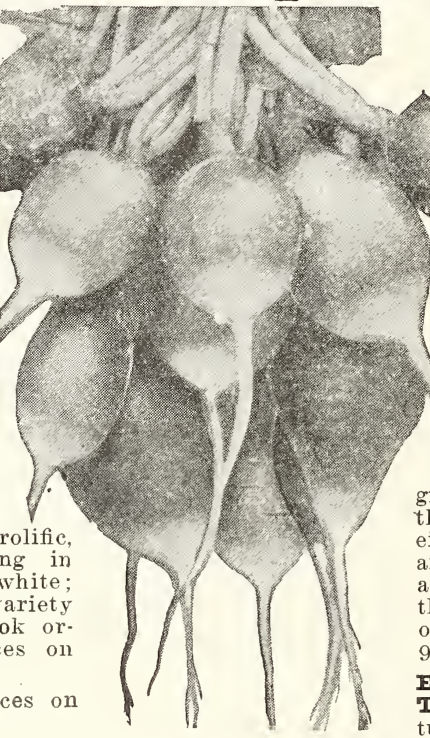

One ounce of seed will sow 100 feet of drill, ten or twelve pounds to the acre. Sow in January or February in hotbeds, and they must nave plenty of ventilation and moisture. Out of doors, sow from March to Septemoer. Radishes inust be grown quickly to be tender and crisp, and quick growth requires rich soil and plenty of moisture.

EARIY SCARIET TURNIP - A round, red, turnip shaped radish with small tops of very quick growth, deserving general cultivation on account of its rich, scarlet-red color, almost crimson, and its white, crisp, tender flesh; the roots often grow one inch long by one and and one-eighth inches in diameter before coming pithy. Pkt. $5 \mathrm{c} ;$ oz., $10 \mathrm{c} ; 2$ oz., $20 \mathrm{c} ; 1 / 4$ lb., $30 \mathrm{c}$ 1 ib., 90c; 5 lbs., $\$ 4.00$, postpaid.

FRENCF BREAKEAST-A quick growing, small, olive-shaped radish, about three and one-half inches long by five eighths to three-fourths of an inch in diameter when fully grown. The color is a beautiful deep rose-scarlet except a lit tle clear white about the tip. Pkt., 5c oz., $10 \mathrm{c} ; 2$ oz., $20 \mathrm{c} ; 1 / 4$ lb., $30 \mathrm{c} ; 1 \mathrm{lb}$. 90c; 5 lbs., \$4.00, postpaid.

FARTY SCARTET TURINP, WHITE TIPPED_-One of the handsomest of the turnip radishes, and a great favorite.

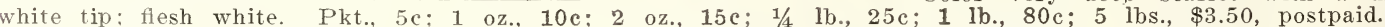

CHINA ROSE WINTRR-One of the very best for fall and winter use, bright rose color, flesh white and firm, Superior quality. Pkt., 5e: oz, $10 \mathrm{c}: 2$ oz., 20c; $1 / 4$ 1b., 30c; 1 lb., 90c, postpaid.

ROUND BIACI SPANISH WINTER-Large, black-skinned radish. Pkt., 5c; oz., 10c; 2 oz., 20c; 1/4 1b.,

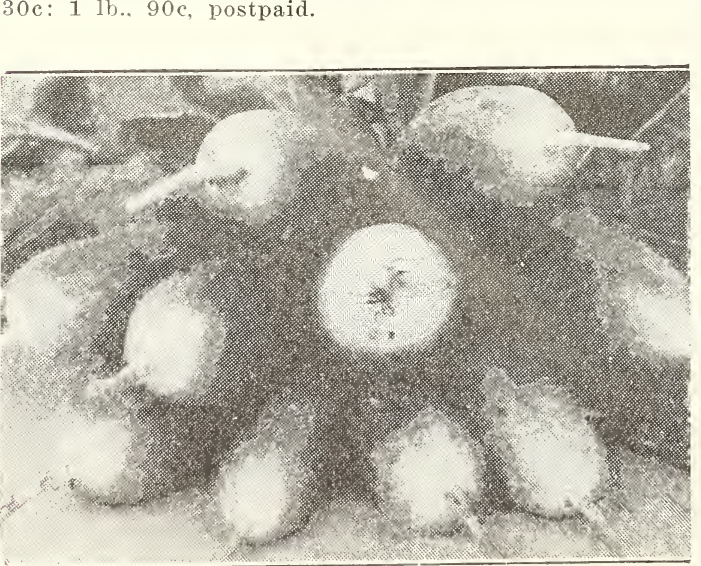

IONG BIACK SPANISH WINTER-Like the above, but the roots are longer and somewhat milder in flavor. Pkt. 5c; oz., 10c; 2 oz., 20c; 1/4 lb., 30c; 1 lb., 90c postpaid.

WHITE ICICIE-One of the best early long, white sorts, suitable either for forcing or growing outside. Roots somewhat shorter and tops smaller than White Vienna. Very crisp and tender and of a beautiful waxy white color. Pkt $5 \mathrm{c} ; 1$ oz., $10 \mathrm{c} ; 2$ oz., $20 \mathrm{c} ; 1 / 4$ lb., $30 \mathrm{c} ; 1$ lb., $90 \mathrm{c}$, postpaid IONG SCARIET SHORT TOP-The best of the long red radishes. It is very early, of good size, fine quality; most largely planted of all long red radishes. Pkt., $5 \mathrm{c}$ 1 oz., $10 \mathrm{c} ; 2$ oz., $20 \mathrm{c} ; 1 / 1$ lb., $30 \mathrm{c} ; 1 \mathrm{lb}, 90 \mathrm{c} ; 5$ lbs. $\$ 3.75$ postpaid.

COOPER'S SPARKIER, WHITE TIPPED-A comparatively new variety. Globular in shape, rosy carmine, with white tip. Solid and crisp; very short top. This is a splendid variety and very popular on many markets. Pkt. $5 \mathrm{c} ; 1$ oz., $10 \mathrm{c} ; 2$ oz., $20 \mathrm{c} ; 1 / 4$ 1b., $30 \mathrm{c} ; 1$ lb., $90 \mathrm{c} ; 5$ lbs. $\$ 4.00$, postpaid.

EARIX WHITE TURNIP-A turnip-shaped white radish Its color is pure white, almost crystal, so clear and trans parent. Its quality is excellent. It is of a turnip shape, 


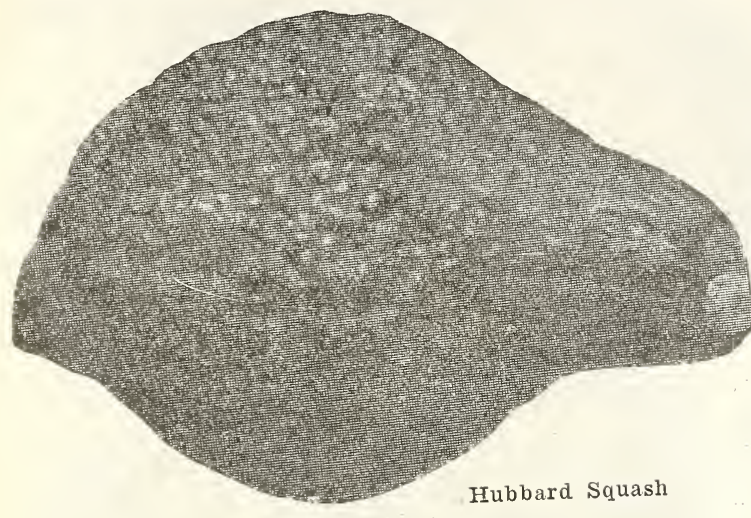

\section{SPINACH}

One ounce to $100 \mathrm{ft}$. row; 10 to 12 pounds per acre.

Requires a very rich, loose, moist soil. Spade or piow under well rotted manure in the fall. For spring culture the rows should be 12 to 18 inches apart and thin to about six inches between plants. Spinach can be sown in the fall for early spring use. Cover seed-bed with straw, leaves, etc.

BLOOIMSDALE SAVOY IEAV ED-A valuable variety with wrin kled leaves, resembling the Savor lific. The most popular sort. Pkt., $5 \mathrm{c} ; 1$ oz., $10 \mathrm{c} ; 2$ oz., $15 \mathrm{c} ; 1 / 1$ lb. 20c: 1 lb. $50 \mathrm{c}$; 5 lbs., $\$ 2.25$, postpaid.

VICTORIA-A popular variety with large dark green and very thick leaves of fine quality; usually blunt or rounded at the ends. About as early as any and remaining fit for use a long time. Pkt., $5 \mathrm{c}$; 1 oz., $60 \mathrm{c}$, postpaid.

\section{BROAD-IEAVED FLANDERS-} One of the most vigorous and strong growing varieties. The leaves are nearly round; uniformly deep green, quite thick and slightly crimped in

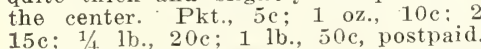
NEW ZEAIAND-This is a plant of a different genus; entirely distinct from the conumon Spinach. It grows 4 to 5 feet high, thrives during the hot weather; can he cut nearly all summer. Plit., 10c: I oz., $20 \mathrm{c} ; 2$ oz., $35 \mathrm{c} ; 1 / 4$ lb., $50 \mathrm{c} ; 1$ lb. $\$ 1.50$, postpaid.

\section{SWISS CHARD OR SPINACH BEET}

One ounce to 100 foot row.

Swiss Chard requires a rich soil and should be planted early. Sow in rows 18 inches apart, about 1 inch deep and thin the plants to 4 to inches in the row. Swiss the highly esteemed for the broad, leaf stalks and midribs, which are cooked and served in the same manner as asparagus, making a most delicious vegetable. The leaves are also cooked like spinach and considered equally palatable. Two distinct dishes may thus be grown from one plant at the same time. Should be in every home garden.

IUCUILUS-A new variety, stalks as thick and broad as rhubarl and leaves light green, much crumpled and curled. Pkt., 5c; 1 oz. 10c; 2 oz., $20 \mathrm{c} ; 1 / 1$ lb., 30c; 1 lb., $\$ 1.00 ; 5$ lbs., $\$ 4.50$, opstpaid.

\section{SALSIFY OR VEGETABLE OYSTER}

One ounce to $100 \mathrm{ft}$. row; 8 pounds to the acre.

Requires a long season and a deep, rich soil. Sow in rows $21 / 2$ feet apart and thin to 6 inches between plants in row. Cover seed three-fourths inch. Salsify is hardy and will stand severe freezing without injury. Prepared and handled the same as parsnip.

MAMMOTI SANDWICH ISIAND-This variety is large and strong, growing with long, smooth, white tapering roots and is less liable to brancli than other sorts. Fine for the home garden. Pkt. 5e: 1 oz. $20 \mathrm{c} ; 2$ oz., $35 \mathrm{c} ; 1 / 4$ lb., $65 \mathrm{c} ; 1$ lb., $\$ 2.25$, postpaid.

\section{SQUASH}

One ounce for 50 hills. About 4 pounds to an acre. (now in hills seeds in a hill, thinning to the five strongest plants. MAMMOTH WHITE BUSH An improved variety of the well known White Bush Squash, growing 12 to 5 inches across; of uniform shape, of a beautiful $5 \mathrm{c} ; 2$ oz., 25c; $1 / \mathrm{l}$ lb., $40 \mathrm{c} ; 1$ lb., $\$ 1.50 ;{ }^{1} \mathrm{oz}$.

( wank orange color with a light shading of eream 25 , postpaid.

reen, smooth and exceedingly hard. Flesh very dark nge 'color and very thick; splendid for baking or pies. 1.25 , postpaid.

ITAIIAN VEGETABIE IMARROW-An English rariety for sum-
mer and fall use. Produces large oblong fruit, dark green at first, it matures Gror ong; the Hesh is white and the shell pale vellow. Pkt., 5c: 1 oz., 20c: 2 oz:, 30c:
postpaid.

YIILOW SUMMER CROOK. NECK-A standard, early and productive summer sort; skin bright rellow, much warted; fruit about 1 foot long. Pkt., 5c; 1 oz., $15 \mathrm{c}$ 2 oz., $25 \mathrm{c} ; 1 / 1$ lb., $40 \mathrm{c} ; 1$ lb, $\$ 1.25$ 5. Ibs., $\$ 5.50$, postpaid.

GOIDEN CUSTARD-This is 4 flattened. scalloped bush squash of low and of very fine flavor. Except for color, this squash is identical with the Mammoth White Bush. This is a splendid yellow variety to plant. Pkt., 5c; 1 oz., $15 \mathrm{c} ; 2$ oz. $25 \mathrm{c} ; 1 / 4$ lb., 40c; 1 lb., $\$ 1.25$, postpaid DEIICIOUS-A fall or winter sort of medium size; top-shaped in forin, dark green in color. The flesh is dark orange, very sweet, dry and delicious. An excellent keeper. Pkt., 5c; 1 oz., $15 \mathrm{c} ; 2 \mathrm{oz}$. $25 \mathrm{c} ; 1 / 4$ lb., $40 \mathrm{c} ; .1$ lb., $\$ 1.25$, postpaid.

\section{RHUBARB}

This delicious plant can be grown successfully in any garden and will continually furnish a tender stock that can be used the entire season for pies and stewing. Without the rhubard in your garden you are missing a luxury that does not require a constant expenditure.

Rhubarb roots for setting out can be easily grown from seed in a single sea son. The seed should be sown in shallow drill or seed bed in the spring, using 1 ounce to 125 feet of drill. When well started, thin to stand 10 to 12 inches apart. Cultivate well. The stalks should not be cut before the third year. For in mediate use order roots which come into use at once.

VICTORIA SEED-The most populax variety. Pkt., $5 c ; 1$ oz.. 30c, postpaid.

RHUBARB ROOTS-We can supply fine roots of above variety. 1-rear roots each 20c; doz. \$1.75, 2 -year roots each $40 \mathrm{c}$; doz., $\$ 3.00$, postpaid. Not prepaid, 1-year roots each $15 \mathrm{c}$ : doz., $\$ 1.25 ; 2-\mathrm{rr}$ roots
each $35 \mathrm{c}$; doz., $\$ 2.50$. 


\section{TOMATOES}

One ounce for about 2,000 plants.

Sow inside in boxes or in hotbeds where the temperature is about 65 degrees. Transplant when three inches high to $3 \times 3$ inches each way. Transplanting will make an abundance of fibrous roots and also stocky plants. Plant outdoors when all danger of frost is past in rows 4 feet apart and 3 feet apart in row. Sunny exposure and fairly rich soil is best. Trim off part of foliage to expose tomatoes to the sun.

ACME (Pink)-A well-known, hardy, early and productive sort; fruit of fair size, round and smooth; color purplish pink. Acme is solid and of excellent flavor Pkt., $5 \mathrm{c} ; \mathrm{oz}^{2}, 25 \mathrm{c} \cdot 2 \mathrm{oz}$ $40 \mathrm{c} ; 1 / 1 \mathrm{lb} ., 75 \mathrm{c} ; 1$ lb., $\$ 2.50$, postpaid.

EARIY DETROIT (Purple)-This splendid variety is the largest and best of the early purplish pink tomatoes. The fruits are very smooth, uniform in size, nearly globeshaped, firm and of excellent quality. Early Detroit is most valuable as a shipping variety, as well as for home or market use. Pkt., 5c; 1 oz., 40c; 2 oz., 60c; 1/1 1b., $90 \mathrm{c} ; 1$ lb., $\$ 3.00$, postpaid.

FARTIANA (Bright Scarlet)-The earliest and best of the very early tomatoes; very productive for an early sort; fruits are of fair size, round, very smooth and solid, and produced in clusters in center of the plant; color bright scarlet. Pkt., 5c: 1 oz., 25c; $207,45 \mathrm{c}$; lb., 85c; 1 lb., $\$ 2.75$, postpaid.

JOHN BEAR (Red) - This variety produces largest fruit of the extra early sorts. Fruits are large, nearly round, smooth, firm, of excellent quality: color bright red. Pkt., $5 \mathrm{c} ; 1$ oz., $35 \mathrm{c} ; 2$ oz., $60 \mathrm{c} ; 1 / 4$ lb., $\$ 1.25 ; 1$ lb., $\$ 3.75$, postpaid.

BEAUTY (Pink)-A productive main crop variety; fruits large and exceptionally smooth, solid and of excellent quality; color purplishpink. This is one of the best midseason or main crop varieties for table use. Pkt., 5c; 1 oz., 35c; 2 $90 \mathrm{c} ; 1$ lb, $\$ 2.50$, postpaid.

IIVINGSTON'S GIOBE (Pink) A variety of almost perfect sliape. Medium size and purplish-pink color. Used very largely for greenliouse planting; also grown extensively in the South for shipping to Northern markets. It is early, productive, of very fine flavor, and firm and solid Pkt. 5c; oz., 35c; 2 oz., 60c; $1 / 4 \mathrm{lb}$ $\$ 1.25: 1$ lb., $\$ 4.00$, postpaid.

PONDEROSA (Purple)-An exceptionally large, purple-fruited tomato, and for the home use of the home use of the
best; fruits very solid, with few seeds. We have a very much improved stock of this variety which lacks considerable of the roughness and tendency to split which it formerly pos-

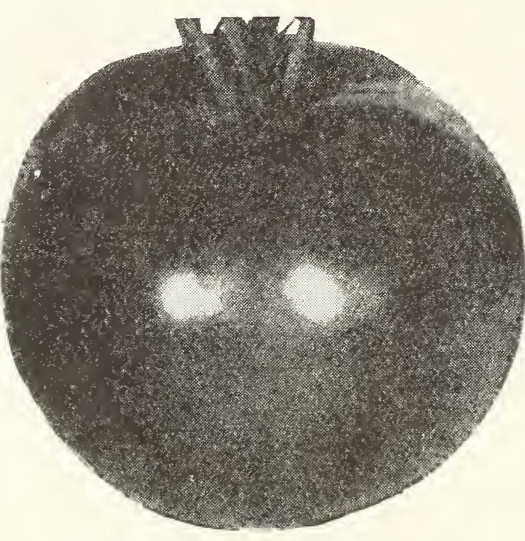

Ponderosa were very satisfactory in this re pinion drought it show ed a little wilt, but, in our opinion, Gulf state about 75 per cent wilt resistant. It gether, permitting the tops to be trimmed to advantage; frui is almost true globe shape, entirely free from cracks, blemishe about the blossom end; fruit on the same cluster ripens uni formly, making it an economical variety to pick. Pkt. 10c; 1/2 oz., 25c; 1 oz., $45 \mathrm{c}$ pick. $80 \mathrm{c} ; 1 / \mathrm{lb}, \$ 1.50,1 \mathrm{lb}, \$ 5$, postpaid JUNE PINK-In habit of growth, pro luctiveness and size of fruit, identical with Tarliana, differing only in having purpl fruit; the best extra early purple or pin fruited variety. Pkt., 5c; 1 oz., $35 \mathrm{c}$; oz., $65 \mathrm{c} ; 1 / 1$ lb., $\$ 1.25 ; 1$ lb., $\$ 4.00$ lostpaid.

\$TONE (Deep Red)-The standard an general favorite with truckers and canners always dependable, very vigorous and pro ductive; fruits round, large, solid, smoot and deep red in color. The most popula of the late or main crop sorts. Pkt.; $5 \mathrm{c}$ of the $25 \mathrm{c} ; 2$ oz. $40 \mathrm{c} ; 1 / 4$ lb., $75 \mathrm{c} ; 1 \mathrm{lb}$ $\$ 2.50$ postpaid.

DWARE STONE (Deep Scarlet)-Pkt 10c. 1 oz, 40c; 2 oz., $75 \mathrm{c} ; 1 / 4$ lb., $\$ 1.25$ postpaid.

DWARF PONDEROSA (Purple)-Pkt $10 \mathrm{c} ; 1$ oz., $60 \mathrm{c} ; 2$ oz., $\$ 1 ; 1 / 4$ lb., $\$ 1.50$ postpaid.

YELLOW PEAR-Pkt., $10 \mathrm{c} ; 1 \mathrm{oz}, 50$ postpaid.

RED PFAR-Used for preserving and t make "tomato figs." Fruits bright, di tinctly pear-shaped. Plit., $10 \mathrm{c}: 1 \mathrm{oz}$., 50 postpaid. 


\section{Turnips \& Rutabagas}

One ounce will sow 200 feet of drill; 2 pounds for an acre. For early use, sow seed of flat varieties in open ground in spring, in drills 1 foot or more apart, using seed sparingly. Thin to 3 or 4 inches apart. For succession sow every two weeks until May. For fall and winter sow in August and September. A good crop may often be grown by scattering seed thinly in the cornfield at the last cultivation.

FXTRA FARIY WIITE EGG-A quick growing, egg shaped, pure white variety. Very sweet, firm and mild. Pkt., $5 \mathrm{c} ; 0 \mathrm{z} ., 10 \mathrm{c}$; 2 oz., $15 \mathrm{c}$; $1 / 4 \mathrm{lb} ., 25 \mathrm{c} ; 1 \mathrm{lb}$, $65 \mathrm{c}$; 5 lbs., $\$ 3.00$, postpaid.

FXTRA IARIY PURPIE TOP MIIAN-A white variety, purple top and strapleaf. This, with the White Milan, is the earliest of all turnips. Pkt., 5c; oz., 15c; 2 oz., 25c; $1 / 1$ lb. $40 \mathrm{c} ; 1$ lb., $\$ 1.25 ; 5$ lbs., $\$ 5.00$, postpaid.

IARGE WHITE GIOBE-Of perfect globe shape; skin white and smooth; leaves large and dark green. Pkt., 5c;1. oz., $10 \mathrm{c} ; 2$ oz., $15 \mathrm{c} ; \mathrm{I} / 4 \mathrm{lb} ., 25 \mathrm{c} ; 1 \mathrm{lb} ., 60 \mathrm{c} ; 5$ lbs., $\$ 2.60$, postpaid.

MAMMOTI PURPIE TOP WIITE GIOBE-The popular variety for general planting. One of the handsomest and most salabl turnips. For home or market it is unsurpassed. It is a large, rapid growing sort, being ready for the table or market in about 65 days, with globular shaped roots. Flesh pure white, and the best flavored of all turnips, raw or cooked. The skin is white, with a purple top. The most desirable sort. Pkt., $5 \mathrm{c} ; 0 \mathrm{z} ., 10 \mathrm{c} ; 2$. $15 \mathrm{c} ; \mathrm{I} / 4$ 1b., 25c; 1 lb., 65c; 5 lbs.. $\$ 2.60$, postpaid.

\section{AMERICAN RED TOP WHITE} GIOBE-A large globular variety, very even in shape and of handsome apeparance. The crown is purplish red and the remaining portion clear white. The flesh is white, of excellent quality and desirable for table use. The variety is a good keeper and fine market sort. Pkt., $5 \mathrm{c} ; 1$ oz., $10 \mathrm{c} ; 2$ oz., $20 \mathrm{c}$; $1 / 4$ lb., $30 \mathrm{c} ; 1$ 1b., $85 \mathrm{c} ; 5$ $1 \mathrm{bs}$., $\$ 4.00$, postpaid.

AMBER GIOBE-Of large size, globe shaped, solid yellow flesh; green top. Fine for table and stock. Pkt., 5c; oz., 10c; 2 oz., 15c; $1 / 4$ 1b., $25 \mathrm{c}$; 1 lb., 65c; 5 lbs., $\$ 2.60$, postpaid.

\section{RID O I PURPIT} TOP STRAPTEAF -

Flat, white, with purple top. Fine grained and tender. Used for early market and table. Pkt. $5 \mathrm{c}$ oz, 10c; $2 \mathrm{oz}, 15 \mathrm{c}$ $1 / 4$ lb., $25 \mathrm{c} ; 1$ lb., $65 \mathrm{c} ; 5$ lbs., $\$ 2.60$, postpaid. SPVPX TOP-The old standard popular salad variety grown extensively for this purpose. Pkt. $5 \mathrm{c} ;$ oz., 10c; 2 oz., 15c; 1/t lb., $20 \mathrm{c} ; 1$ lb., $50 \mathrm{c}$ 5 c; oz., $10 \mathrm{c} ; 2$ oz., $15 \mathrm{c}$

WHITE FIAT DUTCF STRAPIEAF-An extra early pure white, flat-growing variety. Rec ommended for early market. Pkt., $5 \mathrm{c}$; oz., $10 \mathrm{c}$;

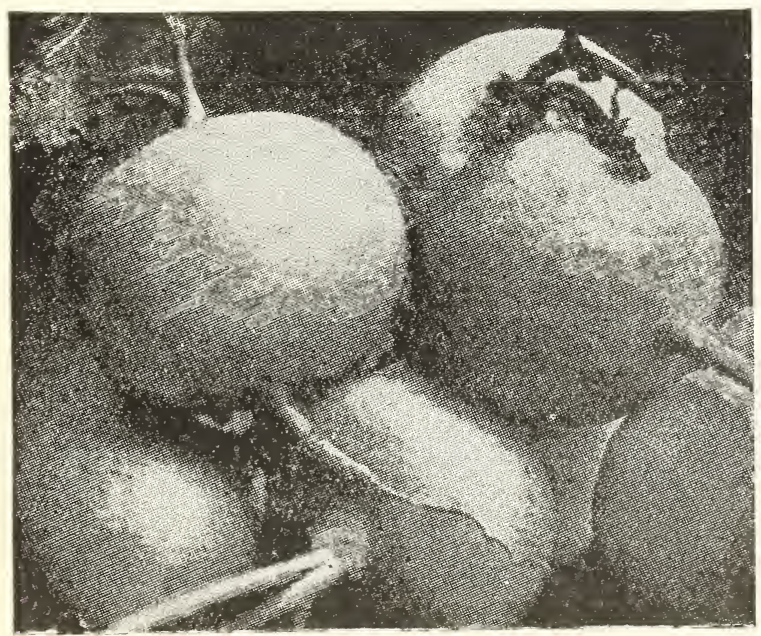

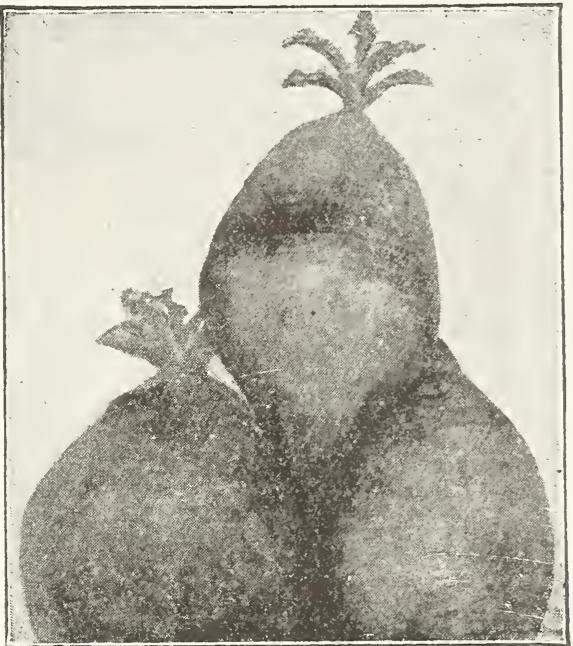

Rutabagas

2 oz., 15o; 1/4 lb., 25c; 1 lb., 65 c; 5 lbs., $\$ 2.60$, postpaid.

YFILOW ABPRDEFN PURPIF TOP-A splendid keeping variety with firm, solid, yellow meat. Pkt., $5 \mathrm{c}$; lb., $65 \mathrm{c} ; 5$ lbs., $\$ 2.60$ postpaid.

IONG WIITE COW FORN-Roots are often 12 to 15 inches long and 3 inches in diameter round, carrot-like in form and slightly crook ed; clear white in color except a shade of green at the top; quality good. $15 \mathrm{c} ; 1 / 4$ lb., $25 \mathrm{c} ; 1 \mathrm{lb}$. $75 \mathrm{c} ; 5$ lbs., $\$ 3.25$, postpaid.

\section{RUTABAGAS}

Sow in drills or broad cast in June, July and August.

MPROVPD PURPIS TOP RUTABAGA-An improved strain of the finest yellow-fleshed rutabaga grown. Hardy, sweet and a good keeper. Pkt., 5c; oz., 10c; 2 oz., 15c; $1 / 4$ lb., $25 \mathrm{c} ; 1$ lb., $75 \mathrm{c} ; 5$ lbs. $\$ 3.25$, postpaid.

WHITE SWPDP, or RUSSIAN-Roots very large, nearly globe-shaped, with a small neck; color white with a green shade at the neck; flesh white, firm and sweet. Pkt., 5c; 1 oz., 10c; 2 oz., 15c; 1/4 lb., $25 \mathrm{c}$; 1. lb., 75e; 5 lbs., $\$ 3.50$, postpaid.

\section{TOBACCO}

The seeds are sown in the Spring. When these plants are almost 6 inches high, set out, 2 feet apart, in drills, with rows 3 feet apart. One ounce of seed will make enough plants to set out three acres.

IAVANA-Grown largely for wrappers of cigars.

CONNFCTICUT SPPD IEA -An early variety for smoking and chewing.

IMPROVED WIITP BURIFY-Fine for both chewing and smoking.

PRICE of any of the above varieties: Pkt., 10c; oz. $50 \mathrm{c}$, parcel post paid.

S0RR $R$ L A hardy plant-grown for its "leaves, which are used as boiling be sown thinly, in drills, early in spring. When well started thin to stand 4 to 6 inches apart in the row. The leaves can be gathered for use at any time after the plants are well started in growth, and the roots the plants are well started in growth, andy. 


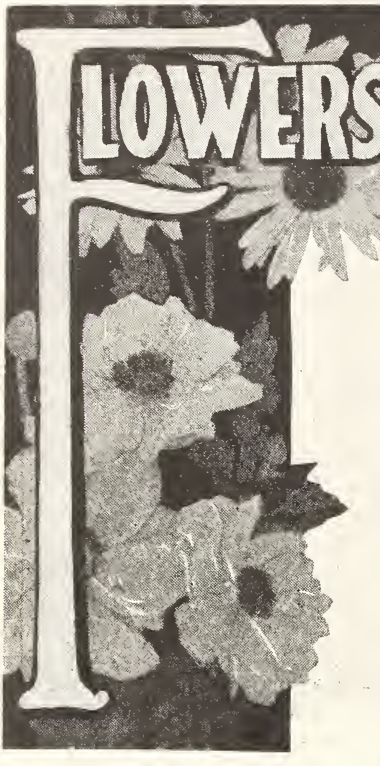

Blame no one but yourself if the next spring and summer finds you without a very representative display of beautiful flowers. Send that order today.

Flower's are so inexpensive, and so easy to have, that they are not generally appreciated in proportion to what they do to make a place comfortable and beautiful. Even one or two sorts near a house, the small ones in beds and the larger plants standing alone, will do wonders toward lighting the place up and making it more homelike and habitable. And a larger collection propertly grouped and arranged over a lawn or garden will make of almost any place a beautiful home and at the same time increase the commercial value of the property.

GENERAL CULTURAL DIRECTIONS-The well-known annual flowers, such as Sweet Alyssum, Calliopsis, Calendula, Marigold, Mignonette, Nasturtiums, etc., sow where they are intended to flower, either in lines or beds, covering not over four times their size, and firming the soil over them. For those which should be started indoors, such as Heliotrope, Celosia, Lobelia, Salvia, Vinca, Verbena, etc., the best plan is to sow in boxes, covering about one-eighth of an inch and pressing firmly; cover with a pane of glass and keep in a temperature between 60 and 70 degrees. Water carefully as needed. Transplant into boxes, an inch apart each way, or put into small pots until time to plant out. They should have an abundance of air.

ANTIRRIINUM (Snapdragon)-Well known showy and useful border plant, producin flowers of great variety of bril. liant and handsome colors; height from 2 to 3 feet. Pkt., $10 \mathrm{c}$ oz., $\$ 1.00$.

AGERATUM-Profuse blooming plants, bearing clusters of feathery flowers the whole summer. Fxcellent for cut flower and fine for large beds in sum ner and pot plants for winter. Height, 2 feet. Pkt., 5e; 1 oz. $40 \mathrm{e}$.

AMARANTHUS - Fine orna mental plant, many are grown have beautiful clusters of brilliant colored flowers, which are very "effective for au tumn decoration. Plkt., 10e; AIYssUM, SWEFT-One the swetest and most useful of summer flowers for edging, bor ders, rọck work, etc., continuous in bloom the entire season. Flowers white, 1 foot; hardy annual. Pkt., 5c; oz., 40c. AIYSSUM, IITTIE GEM-A Sweet Alyssum with pure white blossons, very dwarf and dense growth. It is, perhaps, the finest sort for geometrical flower beds and borders; hardy annual. Pkt., 5c; oz., $5 \mathrm{dc}$. ASTFR, VICTORIA-Magnificent flowers, double clear massive and showy, with regular over lapping petals. The flowers measure 4 to 5 inches across, and the colors include many extremely delicate and some gorgeous shades. The plants are about 18 inches high. Plit., 10c; 1 oz., \$1.25.

ASTFRS, CHINA-Very effective in beds or bor ders. Mixed colors. Pkt., $5 \mathrm{c}$; 0z., $75 \mathrm{c}$.

ASTER, GIANT COMET-In this class of asters the petals are very long and recurved and twisted lear the center. Plants branching about two feet high, more vigorous and taller growing than the ordinary Comet; flowers larger and equal in form. Known as Ostrich Plume. Price, any of the following varieties, packet $10 \mathrm{c} ;$ oz., \$1.50: Pure White, Light Blue, Clear Rose, Scarlet; Comet Asters, all colors mixed.

BACHEIOR'S BUTTON-It has been so perfected that fully 80 per cent of the flowers are double and semi-double; are also increased in size and present many colors and distinct markings; mixed; hardy annual. Pkt., 5c; oz., 35c

BAISAIM, DOUBIE MIXED-Magnificent for outdoor planting, producing in gorgeous profusion varied color flowers; tender anmual. Plit., $5 \mathrm{c}$ : oz., $60 \mathrm{c}$.

BAISAIM APPIE VINE (Balsamina-Curious

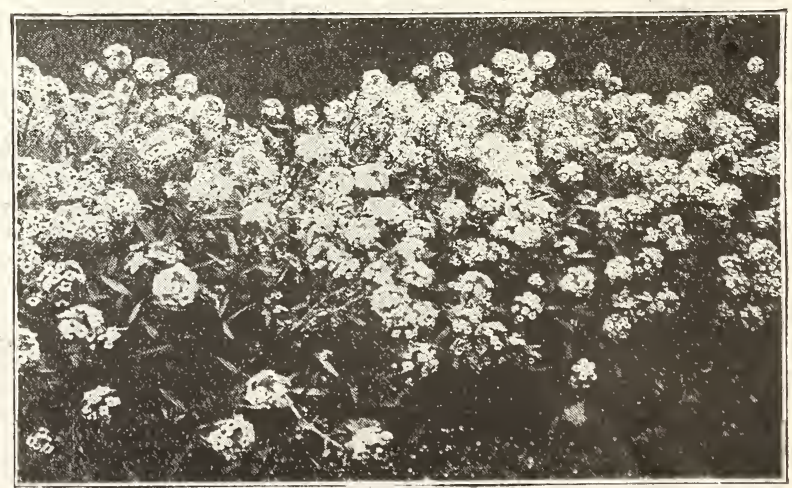

Alyssum fruits; fine climber; annual. Pkt. BAIIOON VINE-A free flowering vine reaching 10 to 15 feet bearing clusters of bloom and numbers of large, round inflated seed-buds resembling miniature balloons. Pkt., 5c;oz., 30c. CANARY BIRD VINE-A dainty vine with beautiful cut leaves and delicate flowers of a clear yel-
low, somewhat resembling a canary with expanded wings. Pkt., 5c; CAIIIOPSIS - Quick growing annuals with brilliant flowers and fern-like leaves. Sow them where they are to bloom compact border they may be plant. ed closer. If eut occasionally they will bloom all spring. Pkt., 5e;

CANDYTUFT-The Candytuft is a popular flower for cutting. Seed sown in the autumn produces flowers early in the spring. Seed sown ster June Successive plantings may be made and thus furnish cut flowers during the entire summer. . They are easily cultivated and look best in beds or masses: Mixture of all varieties and colors. Pkt, $5 \mathrm{c} ; 1$ oz., 30c. CARNATION (Marguerite)-Finest double mixed. Beautiful long-stemmed flowers, sweet-scented and of a large size. If given a slight protection they will live through the winter and begin protection they wing the spring and continue blossoming throughout the summer. spring and continue blossoming througho
Mixed colors: Pkt.; $15 \mathrm{e} ; 1 \mathrm{oz} ; \$ 1.50$. 
COBEA SCANDENS-Cup and Saucers Vine; a climber of rapid growth; valuable for covering trellises, arbors, trunks of trees, etc. ; large, bell-shaped purple flowers; half hardy perennial. Pkt., 10c.

CYPRESS VINE-A slender climber of quick growth, having small finely divided dark green foliage. It has a profusion of scarlet or whita star shaped blossoms and is vers desirable for ornamental trellises or wire supports, Pkt., $5 \mathrm{c} ; 1$ oz., $45 \mathrm{c}$.

COREOPSIS-Fine for cutting; graceful fiowers; hardy perennial. Pkt., 5c; 1 oz., $40 \mathrm{c}$

CARDINAI CIIMBER-A new and brilliant colored climber. Flow ers scarlet, $1 \frac{1 / 2}{2}$ inches in diameter, the tube being $1 \frac{1}{4}$ inches in length. Vines branch freels, attaining a height of from 20 to 30 feet. Start seed indoors in March and transplant. Pkt., 10c.

COsmos-One of the notable fall flowers. A strong, tall-growing annual, with bold flowers of exquisite daintiness and airiness heightened in effect by their foliage of feathery green. It is most effective when planted in broad masses, or long background borders against evergreens or fences. The offer only the choice, large-flowered strains. To make sure of flowering earls, Cosmos should be started indoors and trans. planted into dry, sandy, or poor soil, in a sunny location. Giant Crimson, pkt., 10c; oz., 50c; Giant White, pkt., 10c; oz., 50c; Giant Pink, pkt., 10c; oz., $50 \mathrm{c}$; Giant Mixed, pkt., $10 \mathrm{c}$; oz., $50 \mathrm{c}$.

CORN FIOWFR The well known hardy ammul, noted for its old fashioned flowers. Mixed, all colors, hardy annual. Pkt., 5c; 1 oz., 30c. COIEUS-The most popular of all foliage plants. Easily grown from seed, but must be started in a box in the house or hotbed, as the seed is very fine and when sown is scarcely covered, yet must be kept moist. Tendei perennial. Mixed colors. Pkt., $20 \mathrm{c}$

CANNA, MIXED-Flowers of large size and brilliant colors. Our mixture contains all the tall varieties and all colors. Pkt, 5́c; oz., $40 \mathrm{c}$. COCISCOMB, CEIOSIA-The finest type of the feathered cockscomb. Huge plumes of crimson flowers. Pkt., $10 \mathrm{c}$; oz., $60 \mathrm{c}$.

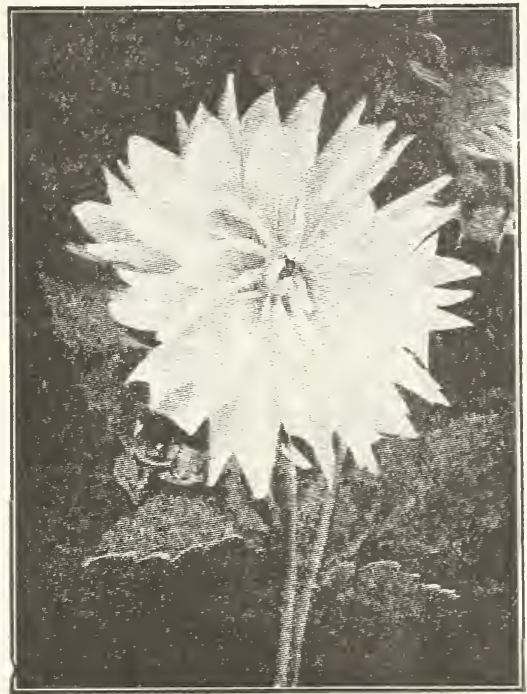

Dahlia
DAHIIAS-It is not generally realized that most beautiful Dahlias may be grown and flowered in late Sum-

mer and Autumn from Spring sown

seed. Many of them, different from any of the named varieties on the market, and some from seed are equally beautiful, the production of novel forms and combinations of colorings being most interesting.

- Single Giant Perfection-This rariety produces fiowers of inmense size of the most bewildering variety of colors. Pkt., $5 \mathrm{c}$; oz., $75 \mathrm{c}$.

-Double Flowering-Double show and fancy sorts. Pkt., $10 \mathrm{c}$; oz., $\$ 1.50$. -Double Cactus. Flowered MixedMany colors, twisted and curled petals. Pkt., 20c; oz., $\$ 3.00$.

DAISY, SHASTA-Hardy perennial, producing flowers of a pure white, oftell measuring 5 inches across. Long stemmed. Excellent as a cut flower. They make a showy hedge as they are cover. ed with flowers from early fall until hard frost. Pkt., $10 \mathrm{c} ; 1 / 1 \mathrm{oz} ., 50 \mathrm{c}$.

DAISY, DOUBIE-A favorite perennial plant, which will stand the winter if given the protection of a few leaves or litter: in bloom from early Spring

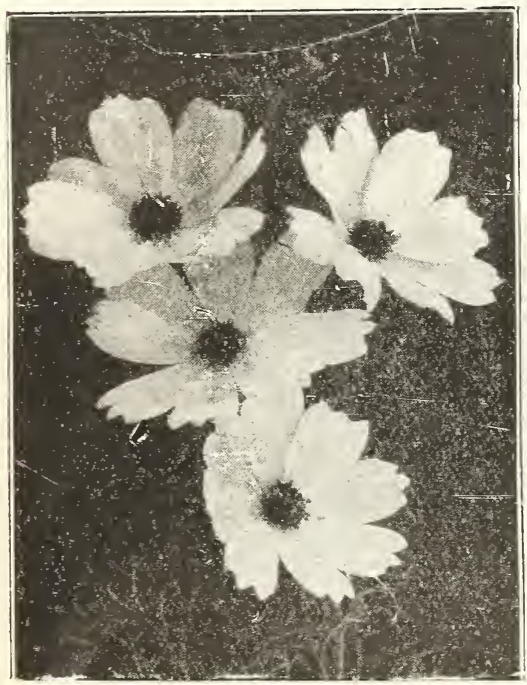

Cosmos

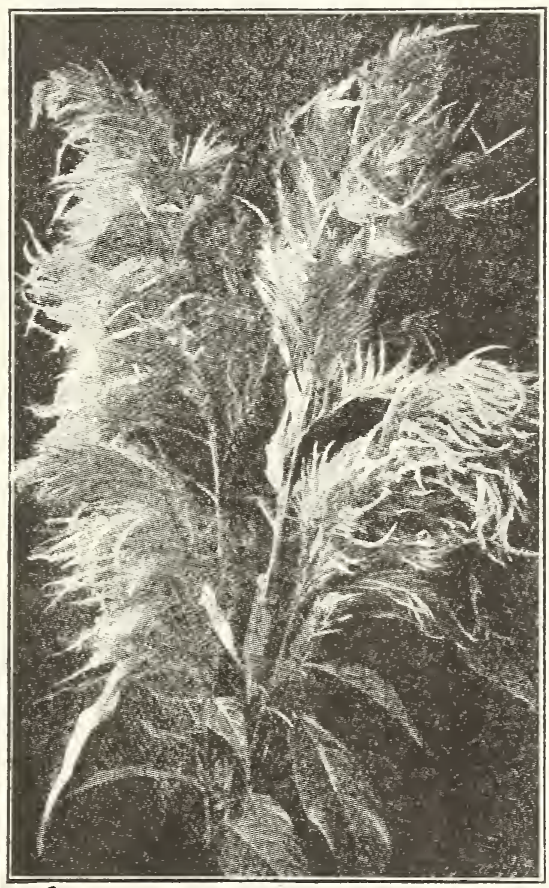

Cockscomb until well on in the Summer. Fasily raised from seed; rus ually sown in August, but can be sown in Spring. Pkt, $10 \mathrm{c} ;$ oz., $\$ 1.50$.

\section{ESCHSCHIOTZIA (Cali}

fornia Poppy) - Brilliant flowers in the shades of crimson, pink, and orange scarlet. The plants are about a foot high. Has finely cut leaves of à grayish green color Blossoms from July until frost. As they are not easily transplanted, s 0 r r a the thicklr. Pkt., 5ૅc: oz., $40 \mathrm{c}$ FORGET-ME - NOT-A pretty little old-fashioned perennial, producing its flowers in early summer, Quite hardy once it is established. Pkt., 10c; 0z., 75c.
FoUR O'CIOCK (Marvel of Peru) - A handsome, free flowering plant. They open their blossoms about 4 o' clock in the afternoon, hence thei name. Hardy annuals: mixed varieties. Pkt, 5c; oz., $20 \mathrm{c}$. FOXGIOVE (Digitalis) Grows to the height of 3 or
4 feet. with dense spikes of brilliantly colored flowers which are terminal and half as long as height of plant Colors, white, lavender and rose. A valuable flower in every perennial garden; does not usually blossom until the Pkt., $10 \mathrm{c} ; 1$ oz. $45 \mathrm{c}$

GOURDS-A tribe of climbers with curiously shaped and colored fruit. Being of rapid growth they are fine to cover old fences, trellises, stumps, etc. Tender annual; 10 to 20 feet high. Pkt., 5c. Dipper Gourd, pkt. 5c; Dish Rag or Luffa, pkt., 5c; Calabash Pipe Gourd, pkt., 10c; Nest Egg Gourd, Pkt., 5c; Gourds, small, ornamental sorts; mixed. pkt., 5c.

GAIIIARDIA (Blanket Flower)-They grow about $1 \frac{1}{2}$ feet tall and from early spring until late fall produce a continuous profusion of brilliantly colored flowers, red and sellow. Pkt., 10c; oz., 50c.

shaped flowers. Cut them in full bloom and dried, ther retain their color. Mixed. Pkt, 5c; oz., $40 \mathrm{c}$.

HEICHRYSUM (Straw Flower) - Of all everlastings the straw flower is the best known. The plants grow 2 to 3 feet high and are covered with large flowers of white, pink, jellow or scarlet. Flowers intended for drying should be gathered when partially unfolded and suspended with their heads downward in a cool place. Pkt., $10 \mathrm{c}$; oz., $50 \mathrm{c}$. perfume makes it a most desirable bouquet flower. Pkt., $15 \mathrm{c} ; 1 / 1 \mathrm{oz} .60 \mathrm{c}$ 


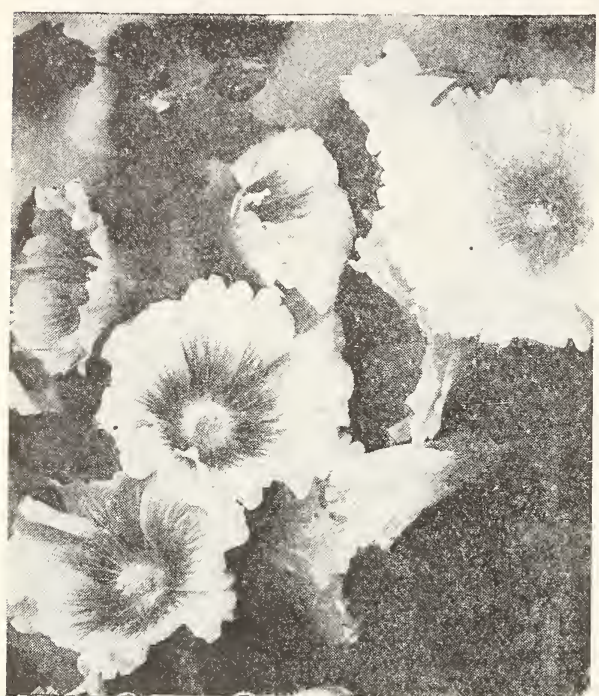

Hollyhock

HOLIYHOCK (Superb Double) - This King of Flowers, growing from six to eight feet tall, cannot be excluded from the old fashioned garden. It forms a splendid background for other hardy perennials and shrub. bery. Seeds sown in the spring will produce blossoming plants the next summer.

-Hollyhock, Double, Mixed-Pkt.,

oz., $\$ 1.50$.

-Hollyhock, Double, White-Pkt., 10c oz. $\$ 2.00$.

-Hollyhock, Double Red-Fkt. 10c, oz. \$2 FUMLUS JAPONICUS (Japanese Hop)Ornamental and rapid climber. The foliage is lovely green; splendid for covering verandas, trellises, etc. Tender annual. Pkt., $5 \mathrm{c} ; 0 \mathrm{z}, 50 \mathrm{c}$

FYACINTH BEAN - A rapid growing annual, flower freely in erect racemes, fol lowed by ornamental seed pods. Sweet scented. Pkt. $5 \mathrm{c} ;$ oz., $20 \mathrm{c}$.

ICE PLANT-A handsome and curious plant for hang. ing baskets, rockwork and vases. The leaves and stems appear as though covered with ice crystals. The whole plant is peculiarly brilliant in sunshine. The flower is white and pink. Pkt., 10c; oz., $50 \mathrm{c}$. IXUDZU VINE (Jack and the Bean Stalk)-It is a rapid growing vine very hardy. Its foliage is very luxuriant and its rose-colored fragrant flowers are produced in large slusters. There is no climber can equal it. Plkt., 10c; 1 oz., $40 \mathrm{c}$

KoCrIA (Summer Cypress)

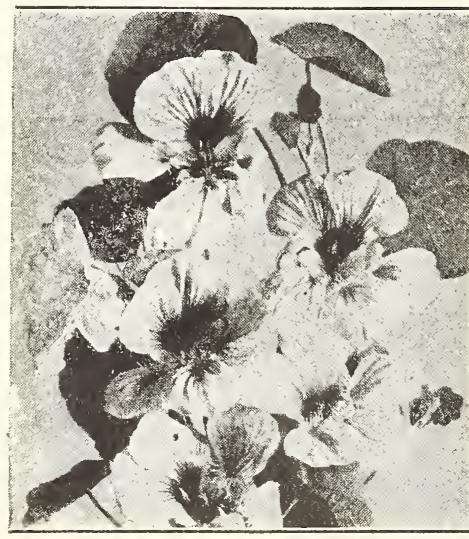

Nasturtium
MARIGOTD (Tall Mixed)-Large, compact flowers in the differen shades of yellow and gold. Plant grows to a good height and form a bush about 18 inches across. Begins to blossom the latter par of the summer and continues blooming until frost. Pkt., 5c; oz., $45 \mathrm{c}$ MIGNONETTE-A very popular flower for cutting. Sowings may be made in April and again in July which will furnish cut flowers for the entire season until frost. They may also be grown in pots for winter flowering. Choice mixed. Pkt., $5 \mathrm{c}$; oz., $30 \mathrm{c}$.

MORNING GIORIES, JAPANESE IMPERIAI-A revelation in the size and beauty of their flower. Pkt., 5c; oz., $25 \mathrm{c}$

MORNING GIORIES-Undoubtedly one of the most profuse flowering vines in cultivation; choice mixed varieties. Pkt., 5c; oz., 15c. NIGEIIA OR IOVE IN A MIST-A hardy annual of easy cul ture producing odd looking flowers and seedpods. Will grow in any garden soil. Flowers blue and white. The plants have fine foliage and attain a height of 1 foot. Pkt., 5 .

NASTURTIUM-One of the easiest flowers to grow and at the same time one of the most popular and pleasing of all varieties. Blossoms a few weeks after it is sown and continues to be a mass of glorious colors until frost. They resemble the sweet peas in that the more they are cut the more they will blossom. Popular for window boxes, verandas, trellises, etc.

Choice Dwarf Mixed Nasturtium-Pkt., 5c; 1 oz, 15c; 2 oz., $25 \mathrm{c} ; 1 / 1 \mathrm{lb} ., 35 \mathrm{c} ; 1 \mathrm{lb} ., \$ 1.25$, postpaid.

-Choice Tall Mixed Nasturtium-Pkt., 5c; 1 oz., 15c; 2 oz., $25 \mathrm{c}$ MOON FIOWER, WEITE-Its large white flowers expand in the
evening and remain open till the following day. Pkt., 10c; oz., 75c.

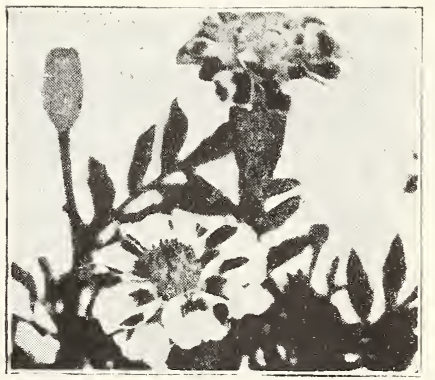

Marigold
MOON FLOWER, HEAVEN IY BIUE-This variety blooms in forenoons. The flowers are azure blue with a yellow throat Pkt., 10c.

PETUNIA - Hardy bedding plant producing flowers of bril liant colors, which come into bloom in June and continue to blossom until frost. As the seeds are very small sow them on the surface and press down with a board, then cover lightly with sand of fine ground.

-Petunia, Single-A splendid mixture of varieties. Pkt., $10 \mathrm{c}$; -Petunia, Large FloweringMixed. Pkt., 15c; oz., $\$ 1.50$.

- Petunia, Double-Finest mixed Plt 25 . PINIS OR DIANTHUS-A popular annual variety known to nearly all. The tlowers are distinguished for their brilliant, contrasting variety of colors appearing in each flower The stripes and spots make the clusters stand out distinctly.

-Pinks, China Double Mixed-Blooms in clusters, flowers very double and in a large range of colors. Pkt., 5c; oz,, 50c.

- Pinks, Diadem Double Mixed-Beautiful flowers in various shades with the outer edges fringed and almost white. Pkt 10c; oz. \$1. fringed and almost white. Pkt., 10c; oz., $\$ 1$. very large and double and of various shades of brilliant colors. Pkt., 10c; oz., 60c.

PANSY-Sow seed in the fall so they will be able to make a good growth before cold weather and produce a mass of early blossoms the next year. Also sown in the spring but will not blossom as early. They thrive best in low temperature, but will do well in

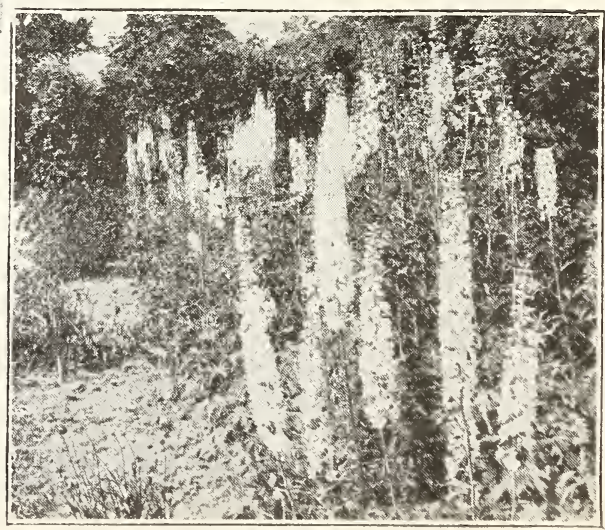

Hardy Larkspur 
any location where the sun is not too hot nor the weather very dry.

-Pansy, Choice Mixed-A splendid mixture of many very fine varieties. Pkt., $10 \mathrm{c} ;$ oz., $\$ 1.00$.

- Pansy, Extra Large Flowering Mixed-A special mixture of all the Giant Pansies; very fine colorings; contains an almost endless variety of shades. Pkt., $10 \mathrm{c} ; 0 z ., \$ 1.75$. -Pansy, Giant Timardeau-A beautiful class; compact growers, with enormous flowers; finest mixed. Pkt., 15c; oz., $\$ 2.50$.

PHIOX DRUMMONDI-The Phloxes are the showiest and most easily raised of all Annuals. We know of nothing which produces such a continuous supply of the most attractive flowers in a most wonderful range of colors. All the tints of the rainbow are represented with all possible variations of stripes, veins and eres of contrasting shades. Seed should be sown in the ground as soon as danger of frost is over and in a few weeks the beds are a blaze of glory.

-Phlox, Drummondii, Mixed-A splendid mixture of all colors; hardy anuual. Pkt., 5c; oz., 60c.

-Phlox, Mammoth, Large Flowering-The largest flowering kinds are a decided improvement on the Drummondii, producing large flowers twice the size of the latter; mixed; hardy annual. Pkt., $10 \mathrm{c}$; oz., \$1.00.

-Phlox, Fireball-Scarlet, superb when in full bloom; hardy annual. Pkt., 10c.

-Phlox, Snowball-Purest white flowers; hardy annual. Pkt., 10c ;

-Phlox, Hardy Perennial-Large and showy; mixed colors; 3 feet. Pkt., 15c.

POPPIFS-Are noted for their satiny flowers of silk-like texture, in many brilliant color combinations. The foliage is delicate and the blossoms are airily poised on slender stems. If the flowers are gathered early in the morning when the dew is on them, they will when the dew is on them, they will
remain fresh in water all day. Plant the seed in succession two weeks apart for a continuous bloom all summer. Mix seed with sand before sowing so as to distribute the seed thinly and evenly. -Poppy, Double Peony Flowered. - Annual variety; mixed; large full, double fringed flowers. Pkt. $5 \mathrm{c} ;$ oz., 20c.

-Poppy, Shirley-These handsome flowers are single, beautiful
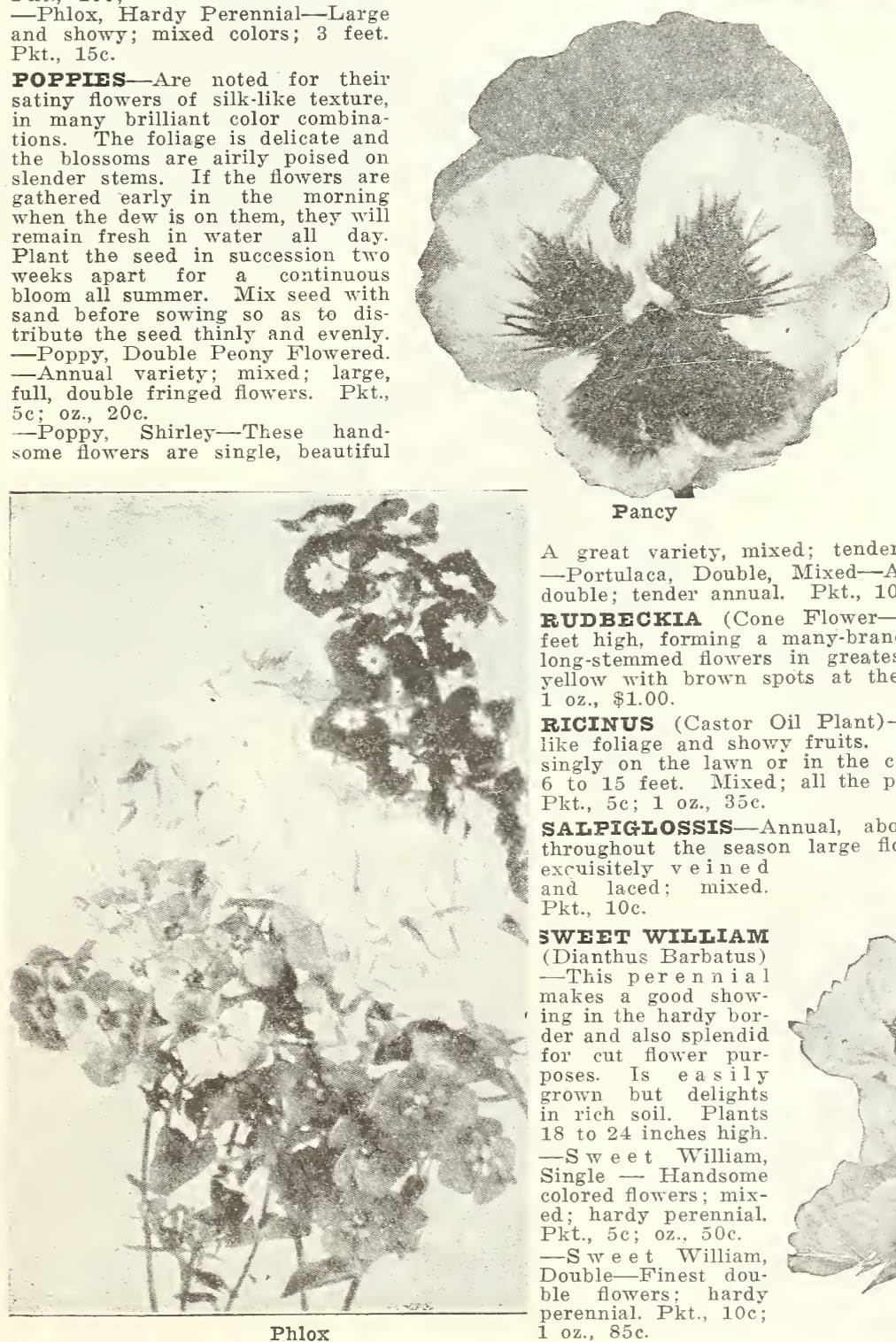

Petunia

in color, from pure white to deep crimson. Pkt., 5c; oz., 30c. -Poppy, Double Carnation Flowered-Extra large and double. Pkt., 5c; oz., 25c.

-Poppy, Double, Fine Mixed-A combination of all varieties, single and double flowers. Pkt., $5 \mathrm{c}$; oz. 25 cents.

-Poppy: Perennial-Hardy perennial variety, of easy culture; in bright, glowing colors. Pkt., 10c. PORTUIACA (Rose Moss)This plant will grow and bloom profusely in dry, hot situation, where almost any other plant would soon die. planted. In sowing mix the seed wianted. In sowing mix the seed distribution. Sow in May when the ground is thoroughly warmed through, and very soon one of the loveliest of floral carpets will ap pear

-Portulaca. Fine Single MixedA great variety, mixed; tender annual. Pkt., 5c; 0z., $40 \mathrm{c}$; double; tender annual. Pkt., $10 \mathrm{c} ; 0 \mathrm{z} ., \$ 2.25$.

RUDBECKIA (Cone Flower-Bicolor Superba)-Grows about 2 feet high, forming a many-branched dense bush, and producing its lon-stemmed flowers in greatest abundance. Disk browu; florets yellow with brown spots at the base; 2 feet; annual. Plkt., $10 \mathrm{c}$; yellow with
1 oz., $\$ 1.00$.

RICINUS (Castor Oil Plant)-Rapid growing plants with palm like foliage and showy fruits. Used with decorative effect, planted sin or in the center of a Canna or Caladium bed, 6 to 15 feet. Mixed; all the plain and fancy sorts; tender annual. 6 to 15 feet. Mixed;
Pkt., $5 \mathrm{c} ; 1$ oz., $35 \mathrm{c}$.

SAIRIGIOSSIS-Annual, about about 18 inches high, bearing throughout the season large flower's of many beautiful colors, all excuisitely, v e i n e d and laced; mixed Pkt., $10 \mathrm{c}$.

SWEET WIIIIAII (Dianthus Barbatus) -This peren n i a 1 makes a good show ing in the hardy border and also splendid for cut flower purposes. Is easily grown but delights in rich soil. Plants 18 to 24 inches high. - S w e t William, Single - Handsome colored flowers; mixed; hardy perennial. Pkt., 5c; oz., 50c. - $\mathrm{S}$ w e e t. William, Double-Finest dou. ble flowers: hardy perennial. Pkt., $10 \mathrm{c}$;
1 oz., $85 \mathrm{c}$.

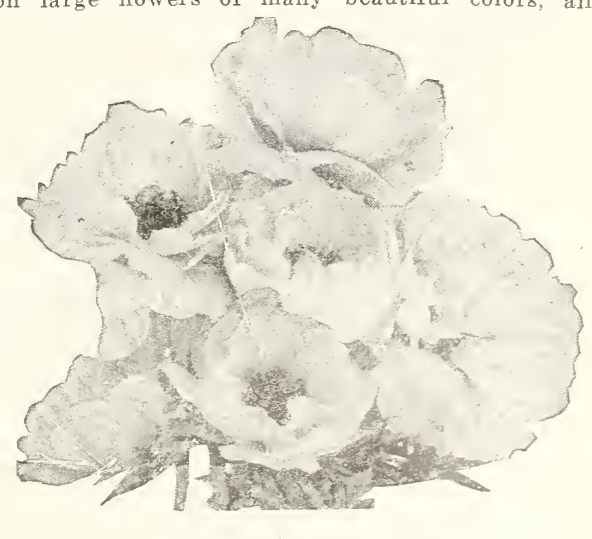

Poppy 
SAIVIA (Scarlet Sage)-The largest flowering variety of Scarlet Sage. Will reach a height of 3 to 4 feet and measure 4 feet across. To have early flowers they should be sown in March in boxes and when the young plants are well started they should be planted 3 feet apart in the flower bed. Is popular as a hedge or border plant, for brilliant color effect. Pkt., $10 \mathrm{c} ; 1$ oz., $\$ 2.50$.

SAIVIA (Clara Bedmans or Bonfire)-Flowers of a most brilliant, dazzling scarlet; one of the finest. Pkt., 15c; oz., $\$ 3.00$.

SCHIZANFIUS (Finest Mixed) - A very popular border plant producing butterfly-like blooms ranging in color from pure white to the deepest crimson. They are easily grown and blossom a few weeks after sowing. They make excellent pot plants for the winter or early spring. Pkt., $10 \mathrm{c}$.

SCARIET RUNNER-A great favorite as an ornamental climber. Bright scarlet sprays of pea-shaped blossoms. Pkt., $5 \mathrm{c} ; 1$ oz., $20 \mathrm{c}$.

SFNSITIVP PIANT-One of the most remarkable and interesting plants in cultivation; the leaves, when touched, instantly fold up. Pkt., $10 \mathrm{c}$.

SWFFT ROCTET-Grows 2 to 3 feet high bears spikes of showy, fragrant flowers, all colors, mixed; hardy peremnial. Pkt., $5 \mathrm{c}$.

STOCKS (Gilliflower) - Stocks are hardy annuals, indispensable in every garden. There are both summer and winter blooming varieties. For either bedding or pot culture they are desirable. Average height of plants $11 / 2$ feet. Dwarf Ten Weeks-Mixed. Pkt., 10c.

SUNFIOWER-Tall growing plants, with large and showy yellow flowers; hardy annuals. Any variety: Pkt., 5c; oz., 30e. Double Dwarf-4 feet. Double Tall-7 feet Single5 feet.

THUINBERGIA (Black-Eyed Susan)-A beautiful, tendex climber, 3 to 5 feet high, with pale yellow or orange-yellow flowers, having a distinct black center. Tender annual. Pkt., 10c.

VINCA (Periwinkle)-Dark green foliaga', handsome rose and white single flowers; very effective for

beds and borders. Blooms continuously all summer from seed sown early in March. half hardy perennial.

-Vinca, Alba-Pure white. Pkt., 10c oz., $\$ 1.00$

-Vinca, Rosea-Bright rose. Pkt., $10 \mathrm{c}$ oz., $\$ 1.00$.

-Vinca, Mixed-Several colors, mixed. Pkt., 10c; oz., 75c.

VERBENA-A low-growing annual, profuse in its blooms, ranging from brilliant: and startling colors to soft and delicate tints. Our mammoth strain produces large. tirusses of brilliant, beautiful flowers.

-Verbena, Choice Mixed-All shades. Pkt., 5c; oz., $40 \mathrm{c}$

-Verbena, Maminoth Mixed-Large flow. ering. Plkt., $10 \mathrm{c} ;$ oz., $\$ 1.25$.

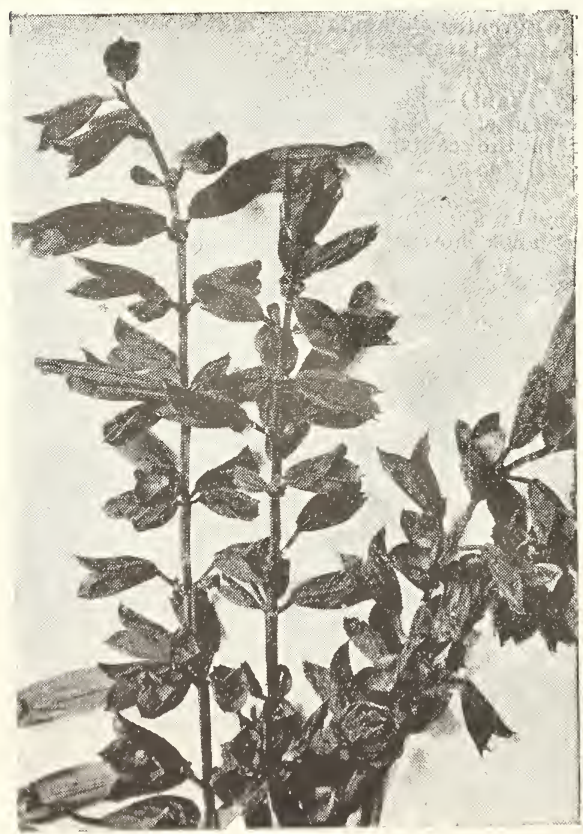

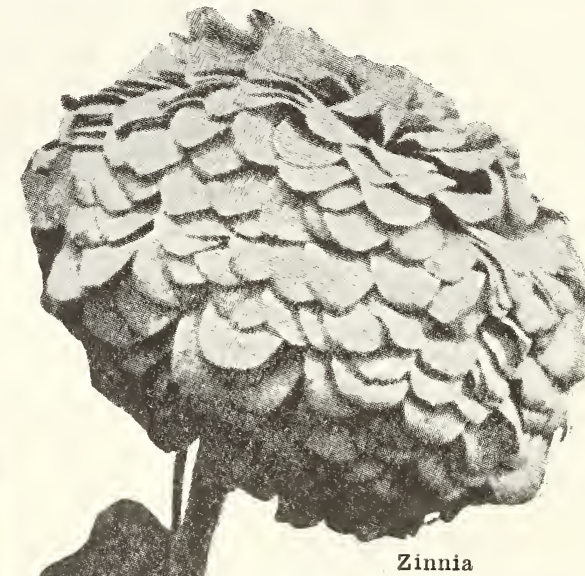

ZINNIA-NFW GIANT FIOWFRING-In this strain of Zinnias we have a flower of perfect form, round, full and double and immense in size. The individual plants form large bushes and bear above the foliage numerous flowers on long, stiff stems, which makes them valuable for cutting and will render them a favorite wherever tried. The plants grow from $21 / 2$ to 3 feet high, while the flowers often measure 5 to 6 inches across, and thickly set with velvety petals.

Giant Crimson-Pkt., $10 \mathrm{c}$; oz., $\$ 1.00$

-Giant Pink-Pkt., $10 \mathrm{c} ; 0 \mathrm{z} ., \$ 1.00$.

-Giant White-Pkt., 10c; oz., $\$ 1.00$

- Giant Yellow-Pkt., $10 ;$ oz., $\$ 1.00$

-Giant Orange-Pkt., 10c; oz., $\$ 1.00$

-Giant Purple-Pkt., 10c; oz., $\$ 1.00$.

-Giant Striped-Pkt., 10c; oz., $\$ 1.00$

-Giant Mixed Colors-Pkt., 10c; 0z, 85c.

NFW DAFITA-FIOWFRED ZINNIAS-In this fine new type of Zinnias the flower petals stand well apart. This characteristic add to the texture of the flowers and lends a graceful and airy appearance. The flowers have a close resemblance to Decorative Dahlias. Many fine colors. Pkt., $15 \mathrm{c}$ : $1 / 1$ oz.. 50c: oz.. $\$ 1.50$.

A well kept lawn should go with every planting of flowers. See page 26 for high grade lawn and grass seeds.

-Verbena, S c a r l e t ering. Pkt., 10c; oz. -Verbena, Mammoth - Large flower- Verbena, Mainmoth hite - Large flower-Verbena, Mammoth urple-Large flower-

WIID CUCUMBER - Ornamenta with curious fruit; re markable for its luxuriance and rapidity of growth. Pkt., $5 \mathrm{c}$; $25 \mathrm{c}$ , 


\section{Superb Spencer Sweet Peas}

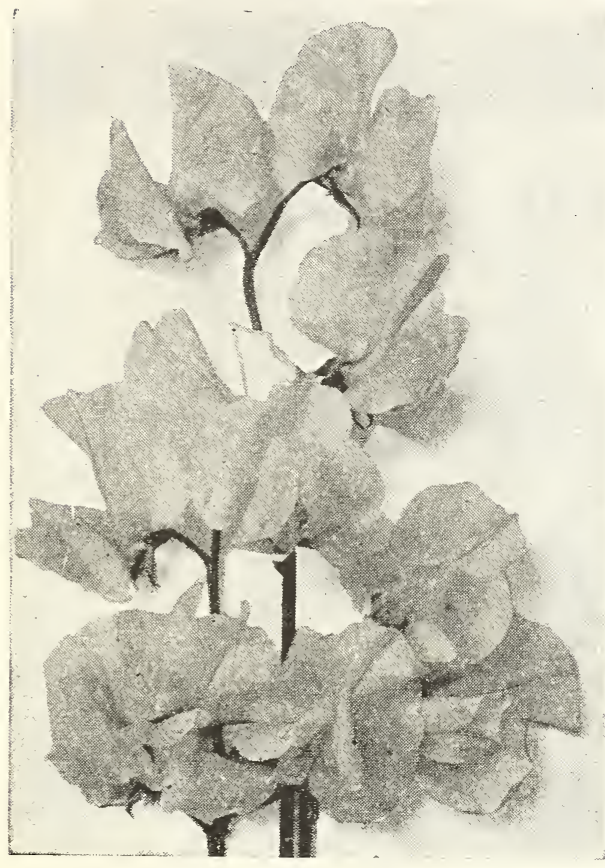

Countess Spencer

Sow in January, February, March or April. Cover seed 2 to 4 inches, according to depth of your trench. The soil for Sweet Peas should be rich and deep, with plenty of well rotted manure in it. Heavy soils must be well worked and fertilized some time before sowing the seed. On high and dry soils they may be sown in drills from 4 to 6 inches deep, covered with an inch or two of soil pressed firmly, and the furrow filled in as the plants grow. When the seed is well above the ground, the little plants should be thinned out so as to be at least from 2 to 4 inches apart. It is a mistake to sow too thick, but it is well to allow for seeds which may rot in the ground or be destroyed by cutworms. In low, damp soils the seed should only be planted an inch and a half or two inches deep, or they will rot during the process of germianting.

Price, any of the following varieties: Pkt., 10c; oz., 35̃ 2 oz., 60c; 1/4 lb., $\$ 1.00 ; 1$ lb., $\$ 3.50$, postpaid.

APPLE BLOSSOM SPENCER-Bright rose standard, with wings of very light primrose flushed or tinted rosecarmine. Very large Spencer form. A free flowering sort and a very reliable bicolored sweet pea of robust growth.

ASTA OHN SPENCER-Suffused lavender or tinted mauve sometimes with pinkish tinge. Spencer form, large and wavy. The best of the lavender sweet peas.

COUNTESS SPENCER-Bright clear pink, sometimes darker towards the edges; very large, open form; long stems. The first variety introduced of the Spencer type and still the best deep pink sweet pea.

ROYAL PURPLE SPENCER-The color is a rich warm purple, the younger flowers having a slightly softer color tone.

KING EDWARD SPENCER-Brilliant crimsonscarlet; very lárge size and open form; best of the pure red or crimson Spencers.

KING WHITE SPENCER-The form, size, vigor, waviness and purity of color give pre-eminence to its claim as the best Spencer yet introduced.

OTHELLO SPENCER-A beautiful, deep, pure maroon of very large Spencer type. The most reliable of the maroon shades of Spencers.

DOBBIES CREAM SPENCER-This is the best of the deep cream or primrose colored peas.

MASTERPIECE SPENCER-Clear lavender slightly flushed rose on standard.

BLUE PICOTIE SPENCER-White, edged with violet blue.

SPENCER SPECIAL MIXTURE-This mixture from all the named sorts of the ruffled or Spencer varieties produces a gorgeous display of wonderful blossoms. Pkt., 5c; oz., 20c; 2 oz., 35c; $1 / 4$ lb., 60c; 1 lb., $\$ 2.25$, postpaid.

\section{CUPID, DWARF OR BEDDING, MIXED}

These from a line of emerald-green foliage, a little over a foot wide and 6 inches high, and from June until late summer are literally a sheet of blooms; the mixture contains all the colors. Pkt., 5c; oz., 25c; 2 oz., 45c; 1/4 lb., $75 \mathrm{c}$, postpaid.
GRANDIFLORA MIXTURE SWEET PEAS

This mixture is composed of all of the largest flowering varieties of Grandifiora Peas. Pkt., 5c; oż., 15c; 2 oz., 25c; 1/4 lb., 40c; 1 lb., $\$ 1.25$, postpaid.

\section{PERENNIAL MIXED SWEET PEAS}

Perfectly hardy, and very handsome freeblooming climbers. They come up year after year. Pkt., 10c; oz., 75c.

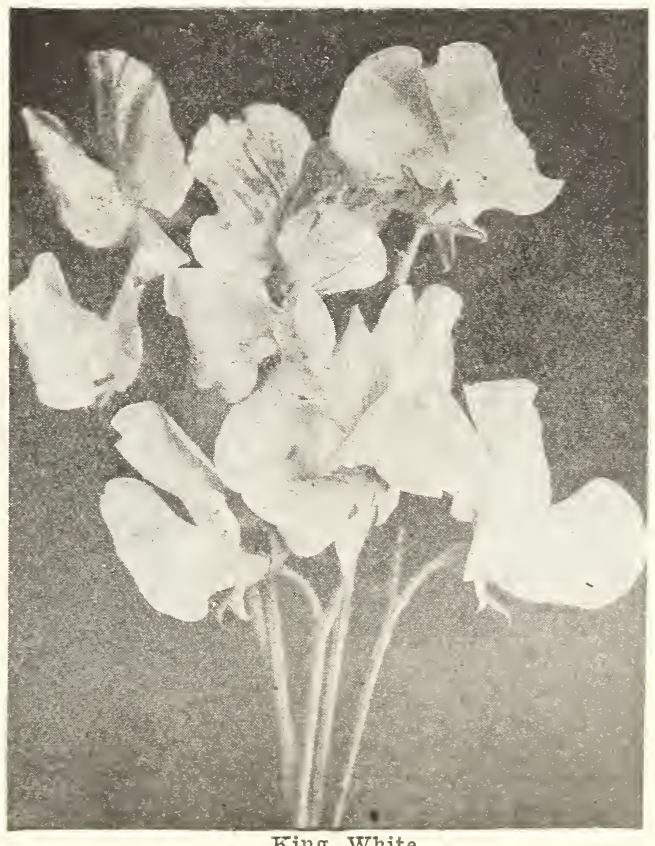




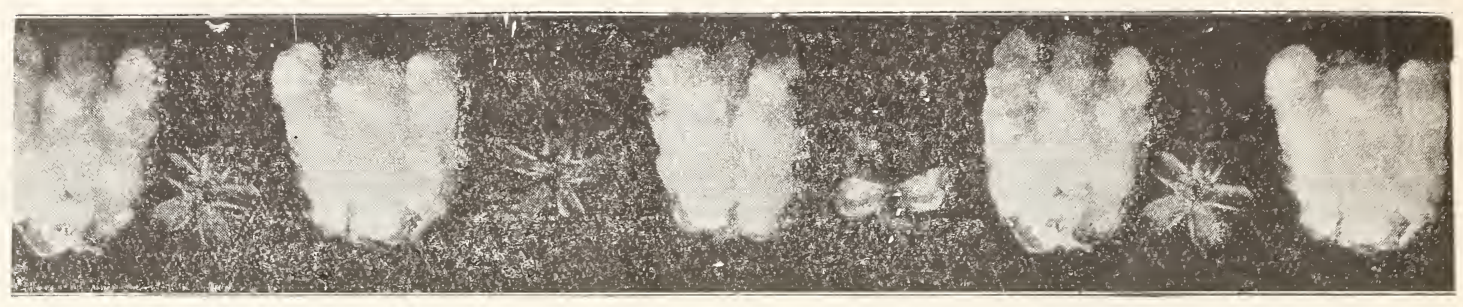

\section{Selected Cotton Seed}

To the Cotton grower there is nothing quite as important as the selection of the proper seed for his soil and conditions, and when the variety is chosen that it should be also selected for its vigor and cotton production pedigree and our offerings are selected for these attributes. Almost every seed must be changed every few years or it "runs out" and does not give the crop it should. Even though you make no change in the variety new seed will much more than repay its additional cost. See page 50 for quantity price on Cotton Seed. KING'S FARIY IMPROVID-A very early, small seeded variety, matures two weeks earlier than any other sort and nearly always thirds itself. On account of its extreme earliness it is largely planted in the boll weevil infected sections, as it matures most of its crop before the weevil makes its appearance.

FAIF AND HAIF-We recommend Half and Half to planters who prefer a short staple, or have the boll weovil to contend with. It is earlier than King's, and stands drouth better than the average varieties. On fertile land, with good seasons, its lint will run as high as 50 per cent. The staple is about 1 inch. We feel sure that anyone who plants Half and Half the com. ing season will be more than pleased. Carolina by W. A. Simpkins, and like King's Improved, and size plants, same size boll; extra early maturity and very prolific-hence it name. When you are looking for an extra early heavy yielding, short cotton, try this variety.

WANNAIMAKER CIEVEIAND-Especially recommended for sections where the boll weevil is present Plant is vigorous, thrifty, with low close-jointed basal fruit limbs; large bolls, easily picked, medium-sized seeds, grayish to greenish. The lint runs 34 to 38 per cent, is fine and strong. 1 to 1 1-16 inches long. as the most valuable short staple cotton ever develope.

SIMPKINS FARIY PROIIFIC-Originated also in from the old Sugar Loaf; in fact, King's and Simpkins are very similar in many ways-about the same shape

ACAIA NO. 5 COTTON-Has given the most satisfactory results. It has proven to be a large boll variety and very early. The plant is of medium height with strong main stalk. The bolls large size, ovate-oblong with short blunt point. The lint will pull strong 1 1-8 inch and the percentage of lint will average 33 1-3. It is considered one of the most desirable sorts to plant in sections infested by the boll weevil.

DEIFOs 6102 -Delfos 6102 is the highest development of any cotton today. It is the result of ten years constant breeding. at the Delta Station, Miss. Delfos produces a plant not over four feet high even on the best delta lands, and sets its fruit early on numerous lateral branches, beginning close to the ground. It is very short jointed and will invariably produce a boll at each joint. The foliage is very light, resembling the willow leaf butter bean. Pulls a staple of $13-16$ inches full, will mature in 100 days, and gives out 31 to $331-3$ per cent.

MEBANE FARIY TRIUMPH-For several years there has been an increasing demand for a tough-fibre cotton of medium staple: something between the ordinary short varieties and long staples. Mebane Triumph is ideal in this respect; pulls from 11.16 to 11.8 inches. has a strong, tough fibre, storm-proof and makes a good "bender" cotton, bringing good premium in price. Extra large boll, easy to pick, drought resistant, lint out-turn at gin 37 to 39 per cent, and one of the earliest of the extra big boll cottons.

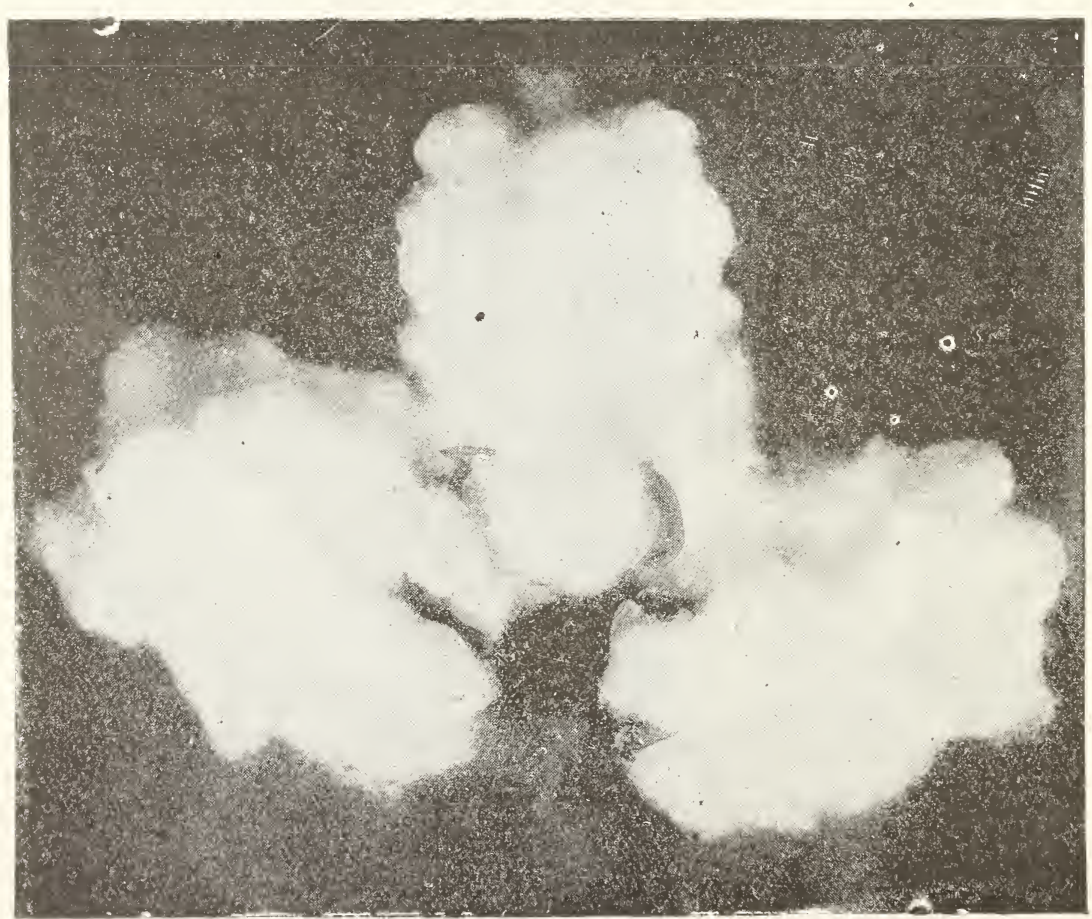

EXPRESS 350 - Express 350 is the best variety to use now, under weevil con ditions, that is available in commercial quantities. Under favorable conditions it will mature in 90 to 100 days, being the best early staple cotton available. It pulls a full $13-16$ inch staple of very even length, and will gin out 29 to 30 per cent lint.

SAISBURY P D I GRERD-This cotton is a cross between Wannamaker Cleveland and Express. The strong points of Salsbury cotton are these: It has the best staple of any short cotton grown and brings a premium; it is very early; it is disease resistant; has medium foliage; it is fast blooming and sets bolls early; it is very prolific; easy to pick and has large bolls makes on our upland sandy lands a staple above one inch, in the Delta 11.8 to $13 \cdot 16$; has good gin. ning percentage; a magnificent quality of lint; high spinning value; the strongest lint ever produced.

See page 50 for quantity prices on Cotton Seed. 


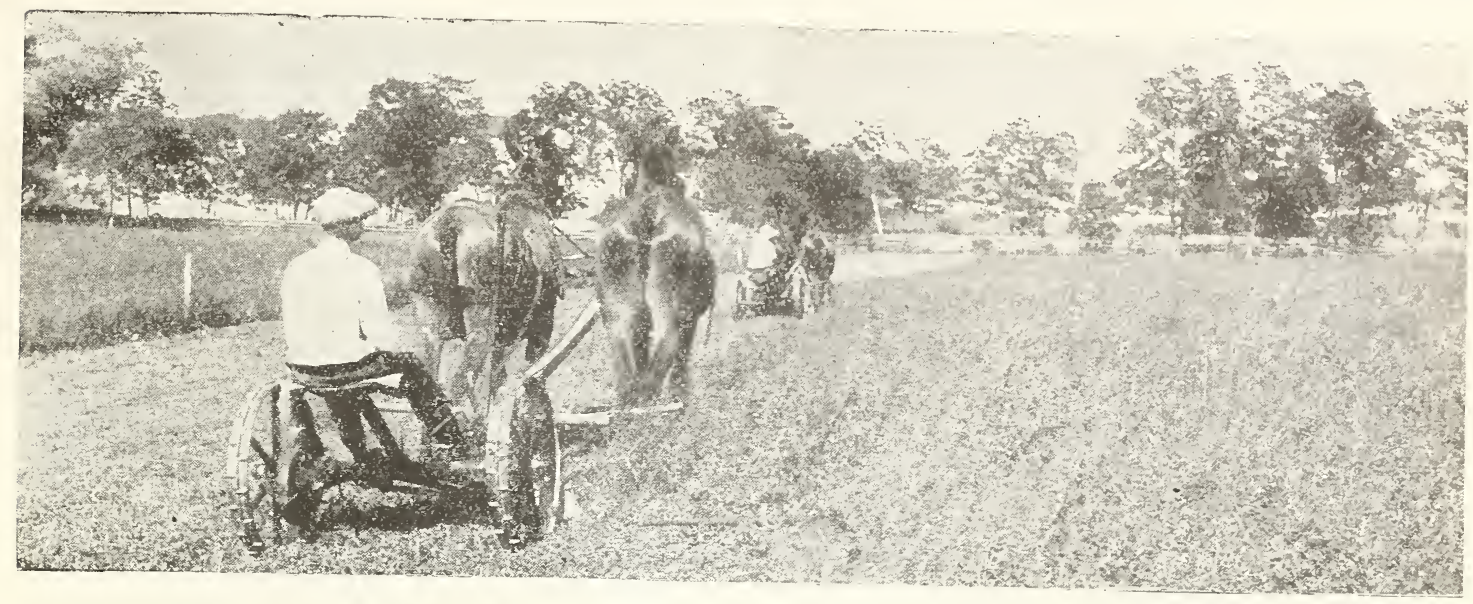

\section{High-Grade Clover}

AIFAIFA CIOVRR-This Clover is being more largely planted in the South every year. When thoroughly ing heavily each cutting. Soil must be thoroughly prepared by deep plowing and harrowing until it is in fine condition. Sow 20 to $25 \mathrm{lbs}$. per acre. Spring seedings may be made during March and April, and in the fall during September and October on any good soil if properly drained.

FANCY KANSAS AIFAIFA-This represents our idea of a real quality and genuine worth in Alfalfasomething to meet all requirements of our most discriminating customers. Lb., $40 \mathrm{c}$; parcel post paid.

DAKOTA NO. 12 AIFAIFA-This variety is the result of years of careful breeding and represents the highest type of Alfalfa. Dakota produces exceptionally hardy Alfalfa, practically immune to Winter killing. Stands drought and heat as well. Highly recommended by Mississippi Experiment Station at Stonerille. Our seed is the genuine Dakota No. 12 stock. Lb., 50c, RED CTOV

pasturage and A valuable farm crop, largely used for custuge and soil improvement. Yields two to three cuttings per year. First crop makes rich feed and is

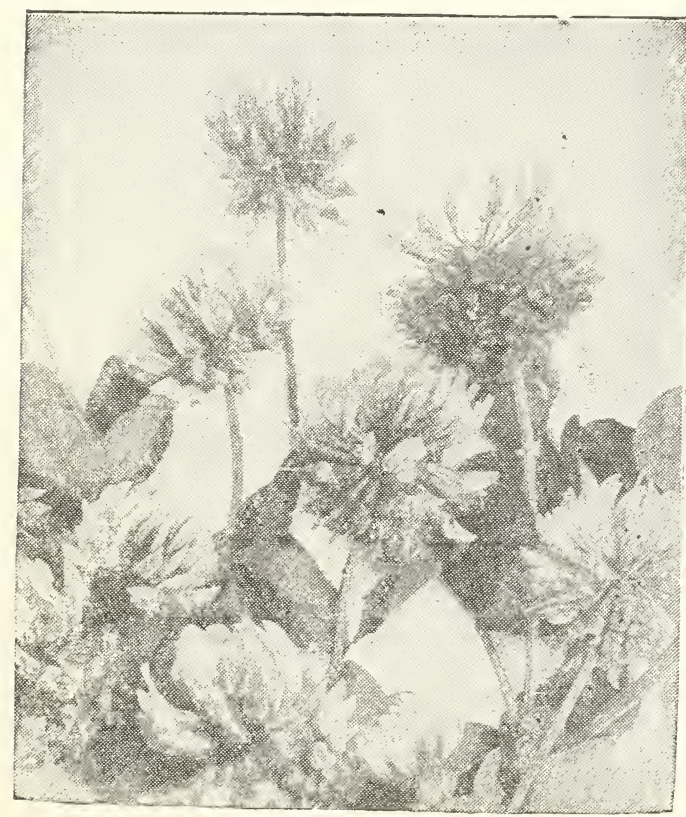

Red Clover air largely and is one of the best soil renovating crops Should inteligently used, is the farmer's best friend. should be used as a rotation crop. Sow in fall or spring. 10 to $12 \mathrm{lbs}$. per acre. Lb., 45c, postpaid.

MAMIOTH SAPIING CIOVER-Very much like the common Red Clover, but larger, heavier and later. Recommended for thin soils. Sow 10 or 12 pounds to the acre. Lb., $45 \mathrm{c}$, postpaid.

JAPAN CIOVER (Lespedeza Striata)-To obtain a good stand, disc-harrow your land, then scatter the seed on top, roll the field; this will cover them enough. Sow in March or April. Seeds weigh 25 pounds per bushel. Sow 20 to 25 pounds per acre. Grows anywhere; is tenacious in any soil; lasts always; well known in the South. It may be classed among the most valuable hay and pasture plants in the South. 1 lb., $35 \mathrm{c}$, postpaid. AISIKE CIOVER-Thrives well on damp soils or in situations where it is impossible to secure a catch of Red Clover. Because seed goes so much further than Red Clover, an dbecause of its comparatively reasonable price this year, many farmers are giving Alsike the preference. It is also largely sown with Timothy. Sow 6 to 8 pounds to the acre in the spring. 1 Ib., $35 \mathrm{c}$,
postpaid.

MEIIIOTUS, OR SWEET CIOVER-A variety of lover which, when young, resembles alfalfa, but on mature development grows from 4 to 6 feet in height. It is exeremeIF vigorous and especially adapted to waste lands, though by many prominent farmers and stock raisers is used on good land for a crop forage. It is very vigorous in growth, standing frost and drought remarkably well, the tap root penetrating the soil very deeply, and occasionally used as a drainage plant for wet soils. It will grow on almost any barren hillside, in bottoms, and is equally adapted to all good farming lands. Sweet Clover is one of the most valuable crops for bees, being the main honey plant in many sections. We handle only the white blossom variety, which we consider the best. Sow 15 lbs, per acre. Hulled seed, 1 lb., $35 \mathrm{c}$, postpaid. BURR CLOVRR-An annual variety which is sown in A. gust and September. Makes superior pasturage, fair and if turned under the following spring, acts as a splendio fertilizer. Grows on any thin land. Sow 10 pounds fancy hulled seed or 20 pounds in the burr, to the acre. Hulled, 1 lb., 40c; in burr, 1 lb., $25 \mathrm{c}$, postpaid.

WIITE CIOVIR-This variety is extremely valuable for It will sant grass mixtures or those prepared for grazing land. It will stand more grazing than any other clover. As the growth is short it has no value in a hay crop. Much is used in lawns. Sow in spring, 4 to 6 pounds per acre. I lb. CRIMSON CIOVRR-Makes excellent green foliage, or if cut when in bloom will make good hay. Especially valuable for improving the soil, making a quick, heavy and very valuable crop for plowing under. Sow 15 pounds to the acre from July to November. Lb., 30c, postpaid.

FUBAN CERTIFIED SWEFT CIOVER-The new an nual Sweet Clover of the White Blossom type. It is excellent for land improvement and also for hay. It makes a Owing to its earliness and profusion of fragrant blooms it is very valuable for bee raisers. 1 Ib., $60 \mathrm{c}$, postpaid. 


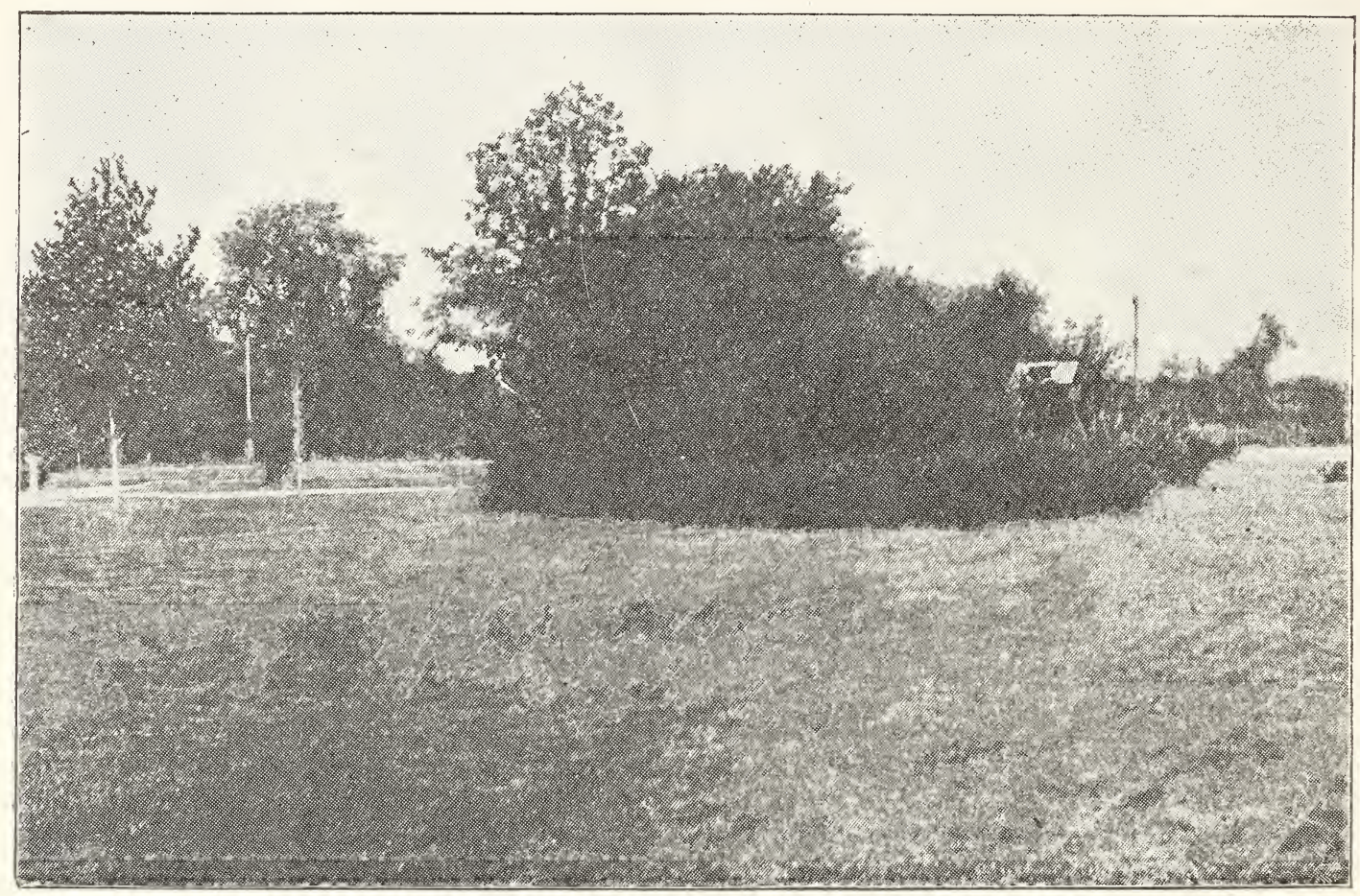

\section{The Best of Grasses}

For those desiring a permanent lawn we are listing below only those mixtures that are beyond question the best obtainable. With these high grade seeds you can either thicken the present lawn or plant an entirely new one. The pasture grasses are weil known and do not need a lengthy introduction, being selected with great care for their vitality and thrifty growing qualities.

IAWN SEFD-It is often difficult to get a good lawn because it has been found that no one grass will give satisfactory results at all seasons and on all soils. Ex periments have proven the value of combining various grasses that will produce an evergreen lawn, giving permanency and beauty of sward. Sow one pound to every 225 square feet, on well enriched, deeply prepared seed bed. An application of bone meal three or four times a year will keep the lawn rich in color. A top dressing of sheep manure will keep the lawn healthy and vigorous.

SUNNY SOUTH IAWN GRASS-1 lb. sows 225 square feet; 40 to $50 \mathrm{lbs}$. sows 1 acre. It is composed of robust-growing grasses and is a satisfactory mixture for parks or large places where lawn and grazing are to be combined, or where special care cannot be given. This mixture will stand dry, hot weather better than the finer lawn grasses. $1 \mathrm{lb}$., $60 \mathrm{c}$; parcel post paid.

SHADY SPOT IAWN GRASS-A special mixture of grasses adapted to growing under trees and in shady places where it is difficult to get other grasses to grow. 1 lb., 60c, parcel post paid.

PERMANENT PASTURE GRASS MIXTUREFurnishes pasture all the season from early Spring through the Winter. Sow in early Spring or Fall, using $1 \frac{1 / 2}{2}$ bushels to the acre. Lb., $35 \mathrm{c}$, parcel post paid.

\section{PERMANENT MEADOW GRASS IMITURE-A} special mixture for a lasting hay crop. Sow in spring or fall, using $1 \frac{1}{2}$ bushels to the acre. Lb., $35 \mathrm{c}$; parcel post paid.

ITALIAN RYE-Recommended principally for fall planting, but can also be sown early in the spring. A very quick growing grass. It is an annual and requires seeding each year. It should be cut when in bloom for hay. Splendid for pasture and lawn mixtures with other grasses. Sow at the rate of two to three bushels to the acre. $1 \mathrm{lb}, 30 \mathrm{c}$, postpaid.
KFNTUCKY BIUE GRASS-This famous grass is well known in all sections and, where the land is suitable, is one of the most profitable of all for pasture. It grows well on any stiff or loamy soils in central and northern states where rich, moist, though moderately well drained, and succeeds fairly well in some section of the South, where lime is present in the soil, being largely used with Bermuda Grass. Kentucky Blue Grass is at its best in the spring and fall months, but being rather sensitive to heat, does not grow luxuriantly during the summer months. It takes a considerable time to get a good stand of this, as it grows very slowly at the start; when once established forms a close, com pact turf, making a fine pasture; also fine for lawns. 1 lb., $50 \mathrm{c}$, postpaid.

CARPET GRASS-Excellent for lawns or pasture pur poses on coast and all sandy lands. Grows equally as well on uplands. It stays green all year. Stools heavily from one parent stalk and spreads rapidly. Blades are wide and give fine forage, and, when well set, forms thick, green carpet that cannot, be uprooted by any amount of grazing. Sow 7 to 10 pounds to acre broad. cast. $1 \mathrm{lb}, 40 \mathrm{c}$, postpaid.

FNGIISF BIUE GRASS (Meadow Fescue or Ralldall Grass) - A splendid grass for permanent pastures, starting early and also furnishing excellent pasture very late in the season. It also makes good hay, growing on almost any soil, thriving best in that which is moist. Per lb., $45 \mathrm{c}$, postpaid.

PERMANENT HOG PASTURE GRASS MIXTURF -A combination of mixed clover and best grass suitable for hog pasture. Sow in early Spring or Fall at rate of 1 bushel to the acre. Lb., $40 \mathrm{c}$, parcel post paid.

TIMOTHY AND AISIKE MIXED-Suitable mixture for wet lands, furnishing good pasture and hay. Sow il early Spring and Fall, 15 pounds of the mixed seed per acre. Lb., $35 \mathrm{c}$; parcel post paid. 
ENGIISH RYE-Very valuable variety for permanent pasture also for lawn purposes. It makes a very heavy leaf growth for pasture or hay. Withstands drouth to a remarkable degree. Used extensively throughout our section for lawns. Use it in Bermuda sod to keep the lawn green during the fall, winter and early spring, when the Bermuda is dormant.

JOHNSON GRASS-A most prolific perennial hay and pasture grass, eminently suitable to hot, dry climate and soils. It makes excellent hav and furnishes an enormous amount of grazing. No drouth, methods of culture or application of chemicals to eradicate it will destroy it when once sown, therefore, we do not recommend it to be sown on any land which is intended in future years for other crops. The best time for cutting is before the heads appear, as, if allowed to ripen, it becomes unfit for stock. Sow in March or April, 1 to $1 \frac{1}{2}$ bushels per acre. 1 lb., $35 \mathrm{c}$, postpaid.

ORCFARD GRASS-This is one of the very best grasses for upland, or moderately stiff soils, affording a large amount of pasturage as well as making excellent hay if cut when in bloom. It grows about 3 feet high and matures much earlier than Timothy, does not exhaust the soil and will produce 2 to 3 tons per acre of

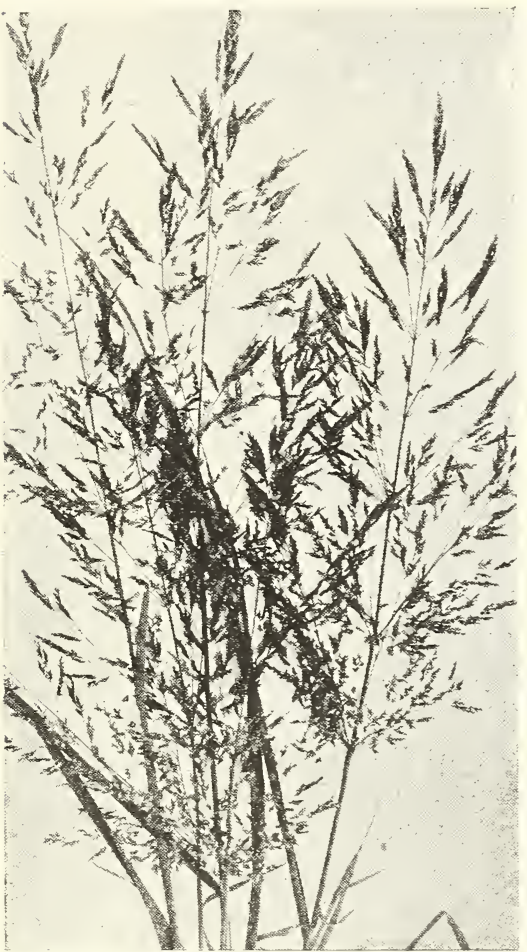
fine hay. Having a tendency to grow in clumps, it $1 \frac{1}{2}$ to 2 bushels being the amount usually sown. It does especially well if used with other grasses. $1 \mathrm{lb}$. $30 \mathrm{c}$, postpaid.

BERMIUDA GRASS Very popular and a great boon in the South for pas

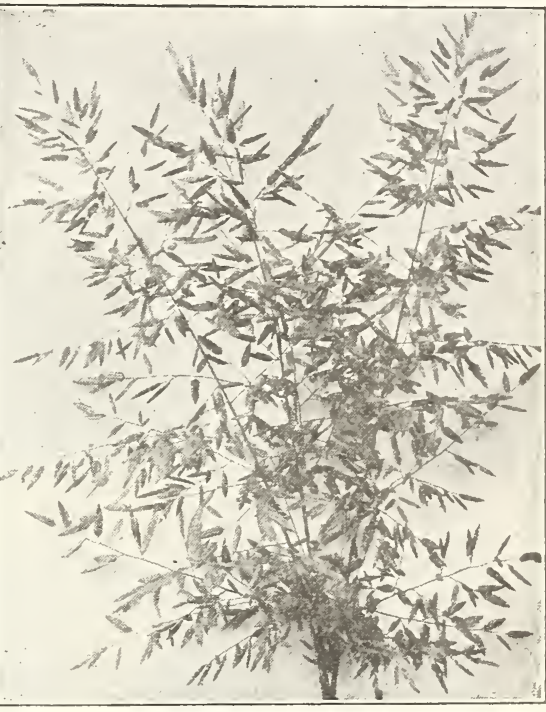

Orchard Grass

ture; when once established, no amount of drought or hot weather wil kill it out. It succeeds on nearly all soils, furnishing a constant growt of grass during the Summer, but becomes brown and bare in the Fal. and Winter. It cannot be recommended too highly for pasture and general culture in the South, and it is also excellent for Summer lawns. Its strong, creeping roots will absolutely prevent wash. Per lb., $45 \mathrm{c}$ postpaid.

TAII MEADOW OAT GRASS-A tall growing grass with flat leaves. It has proven very hardy and may be sown either in the fall or spring. It will do well on woodland pastures where it is possible to prepare the soil thoroughly. Ready to cut for hay as soon as it blooms. A good stand can be cut two or three times a season; $30 \mathrm{lbs}$, of seed to the acre. 1 lb., $45 \mathrm{c}$, postpaid.

REODES GRASS-It is a perennial, growing from three to four fee high, with large numbers of very long, narrow and tender leaves, and with rather a few branching seed spikes or slender branching stems. It is a species that does not spread by under ground root-stalks, but produces running branches which root at the joints or nodes, thereby producing new plants. The runners are not so abundant when the grass is growing thickly, and, therefore, does not materially interfere with the machinery at the time of harvesting the hay crop. Per 1b., $75 \mathrm{c}$, postpaid.

PASPAIUIM DIIATATUM, OR DAIIAS GRASS-Sow eight to ten pounds to the acre. Has given splendid results in the South. It is an ideal grass for dairy farmers, as it produces enormous quantities of fresh, green, juicy feed during the hottest weather. It also keeps green during the winter. Germinates slowly and requires from three to four weeks of warm, moist weather to sprout. to March, 8 pounds per acre. Lb., $60 \mathrm{c}$ postpaid.

TIMOTEY-No grass is better known than this, nor-more generally grown, as it produces the best hay of all grasses, but is of little value for pasture. It produces good hay on almost any class of land, but in this section is best suited to bottom lands or good, well-drained soil. Yields about $1 \frac{1}{2}$ to 2 tons hay to acre. 1 lb., $20 \mathrm{c}$, postpaid.

SUDAN GRASS-A forage crop of immense value. Sudan is an annual, therefore it is necessary to sow every year. Plant grows tall, 7 to 8 feet, stems very small and tender, stools wonderfully makes fine hay and much relished by stock. Yields 2 to 4 tons per acre. Sow in April, in drills or broadcast, using 3 pounds to cast, 14 to 20 pounds will plant an acre. Sudan can be cut two or three times during the season. 1 lb., $25 \mathrm{c}$, postpaid.

RED TOP OR HERDS GRASS-Succeeds better on more soils than any other grass and in all sections of the United States. Grows slowly but becomes very vigorous later and spreads rapidly into a compact sod. Suitable to stiff soils and in low situations subject to overflow, producing luxuriant growth, attaining a height of 3 to $3 \frac{1}{2}$ feet. For the best quality it should be cut when in bloom; ripens about the same as Timothy. 1 lb., $35 \mathrm{c}$, postpaid

See page 38 for fertilizers that will build up your ground and make better crops.

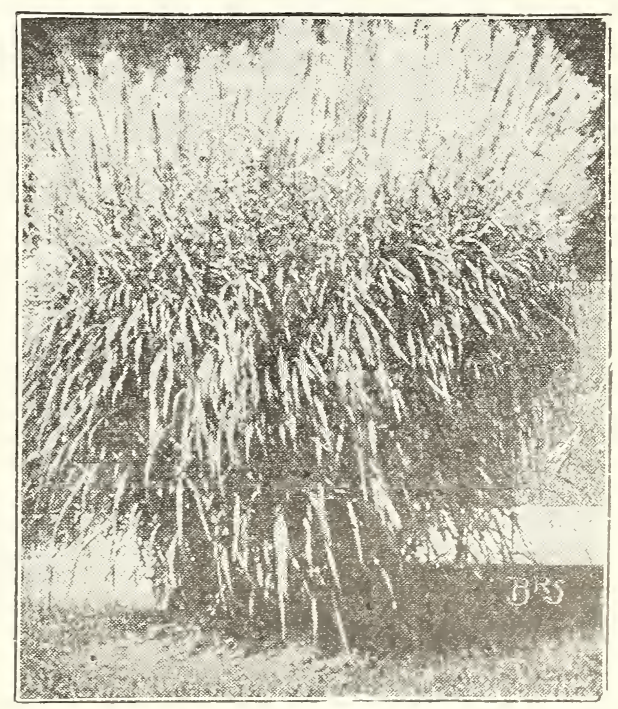

Sudan Grass 


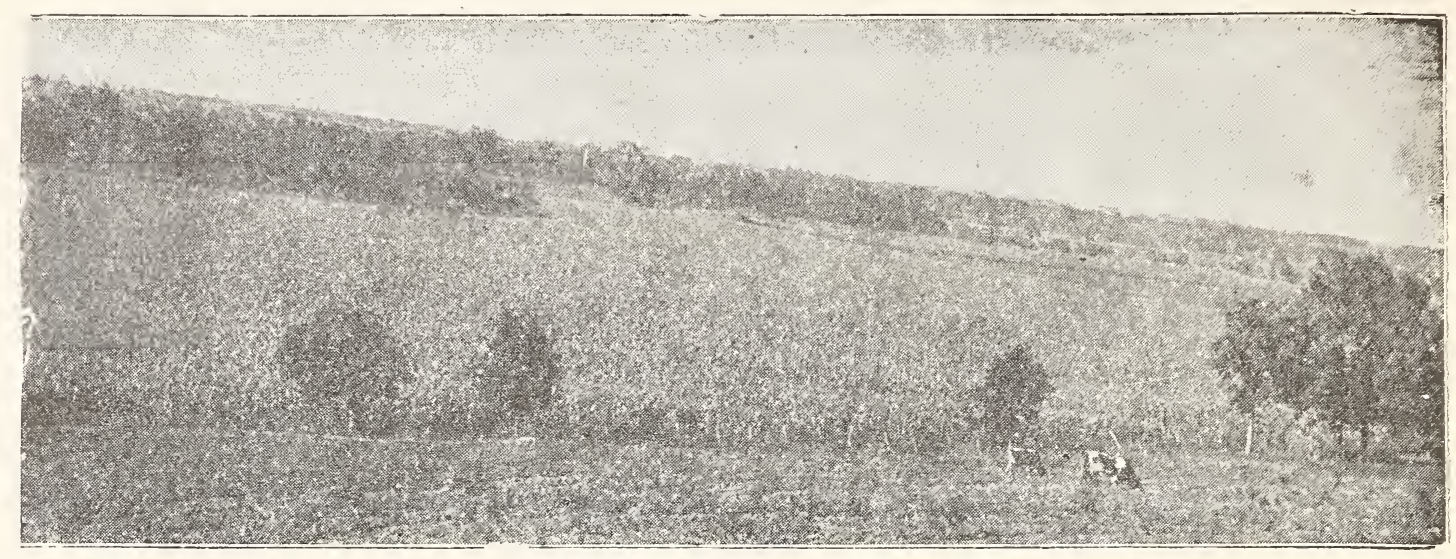

\section{Seed Corn that Satisfies}

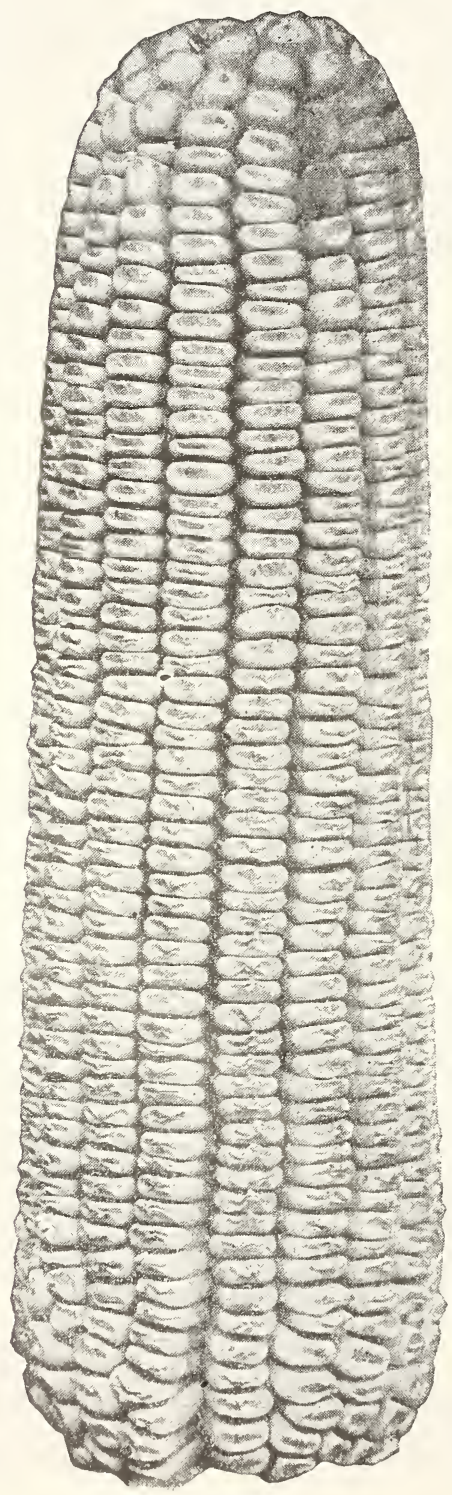

Mosby's Prollific
TAIT'S EARLY WHITE DENT (90 days)-The stalk is short and thick. The ears grow long on the stalk, from 7 to 9 inches in length, almost parallel throughout, of medium size, averaging 14 rows of grains. The grains are pure white, compact and heavy. The cob small. Qt., 30c; 4 qts., 75c, postpaid.

IOWA SIVER MINE (100 days)-The stalks grow to a height of 7 to 8 feet and set the ears about $31 / 2$ to 4 feet from the ground. The ears measure from 10 to 12 inches in length. They are very uniform in size and shape, 16 to 20 straight rows of deep, pure white kernels on a small cob. It is the heaviest yielder we know, having yielded over 100 bushels to the acre. Seventy pounds of ears will make 62 pounds of corn. It is entirely distinct and will give satisfaction. Qt., 25c; gal., 70c, postpaid.

MOSBY'S PROLIFIC (120 days)-The most prolific corn in existence; the stalks are tall, bearing 3 to 5 fine ears. The grains are long, set close to a small cob, very uniform in shape, well filled. It has good roots and will withstand storms better than any other prolific sort. Another important feature of this fine corn is its abundant foliage, which renders it superior to most sorts for ensilage purposes. This is a Southern corn, and is recommended for general crop. It is purely white, small cob, deep full grain, neither too hard no too soft, and stands crowding in the drill as close again as any other kind. Ears of medium size. Quart, 30c; 4 qts.,

ST. CHARLES WHITE, RED COB (100 days)-A large medium late, tall-growing variety, producing an abundance of fodder. The ears are very large, both in length and circumference. The grains are long, broad, deep and firmly set in a medium large red cob. Qt., 25c; 4 qts., $70 \mathrm{c}$, postpaid.

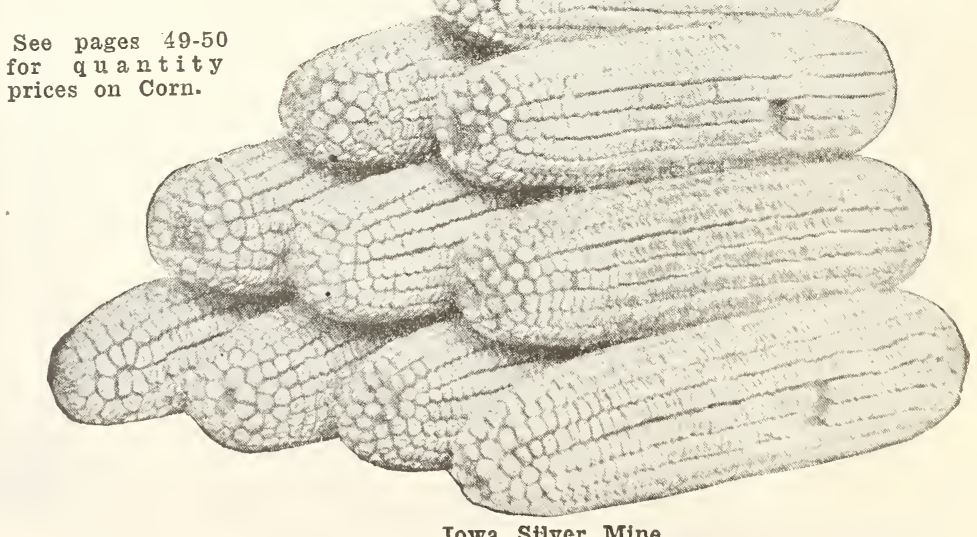

Iowa Stlver Mine 
NEAL'S PAYMASTER-This corn was originated in Williamson County, Tennessee. The grains are pure white, deep, broad and set very solid on a red cob of medium size. The stalks grow from 8 to 10 feet high. The ears are very uniform in size and shape, running from 9 to 12 inches in length, containing 16 to 20 rows, and averaging in weight from 1 pound to $1 \frac{1}{4}$ pounds. This is a highly bred corn, containing a high percentage of protein. Maturing about medium, it is well filled at both butts and tip. Every stalk bears two well-developed ears. Qt., 30c; 4 qts., 75c, postpaid.

MEXICAN JUNE-This is a valuable addition to our large and selected list of field corn, best adapted for the South, has been thoroughly tested in the past and has proven all that was claimed for it. It is a strong, robust grower, sending the roots deep into the soil. Stands heat and drouth well. Ears large, small grain and well covered with shucks. Should be planted in succession from middle of April to end of July. Qt., 25c; 4 qts., 70c, postpaid.

TENNESSEE RED COB, WHITE-A large, white, red cob corn. Ears are medium size, 16 to 18 rowed; grains are very large, deep, wide and thick. Matures in 100 to 110 days. This corn makes fine meal. Qt. 30c; 4 qts., 75 c, postpaid.

HICKORY KING-100 days. The cob is so small and the grain is so large that when an ear is broken in half one grain will cover the entire end of the cob. Nearly all of the stalks bear two ears, and we consider it one of the best white corns grown. Does well on thin land. Qt., 25c; 4 qts., 70c, postpaid.

CHAMPION WHITE PEARL-A highly bred, pure white 90-day corn, large ear and a heavy yielder. Ears about 12 inches long and average 1 pound in weight. Uniform in weight, size and color. Qt., 25c; 4 qts.

\section{YELLOW VARIETIES}

NINETY-DAY EARLY YELLOW-This is a standard variety; matures quick and yields good crop. Is used extensively by truckers and market gardeners. Qt., 25c; 4 qts., 70c, postpaid.

YELLOW LEAMING-A very early growing corn; matures in about 90 days; always dries out quickly, therefore a desirable variety for early crop. Qt., 25c; 4 qts., 70c.

TENNESSEE MAMMOTH YELLOW-Ears are of a perfect shape, long, and filled out to the end of the cob. The grains are not of a flinty type, neither are they so soft. A Southern grown large-eared yellow corn, sure to give satisfaction. Quart, $30 \mathrm{c} ; 4$ quarts, $75 \mathrm{c}$, postpaid.
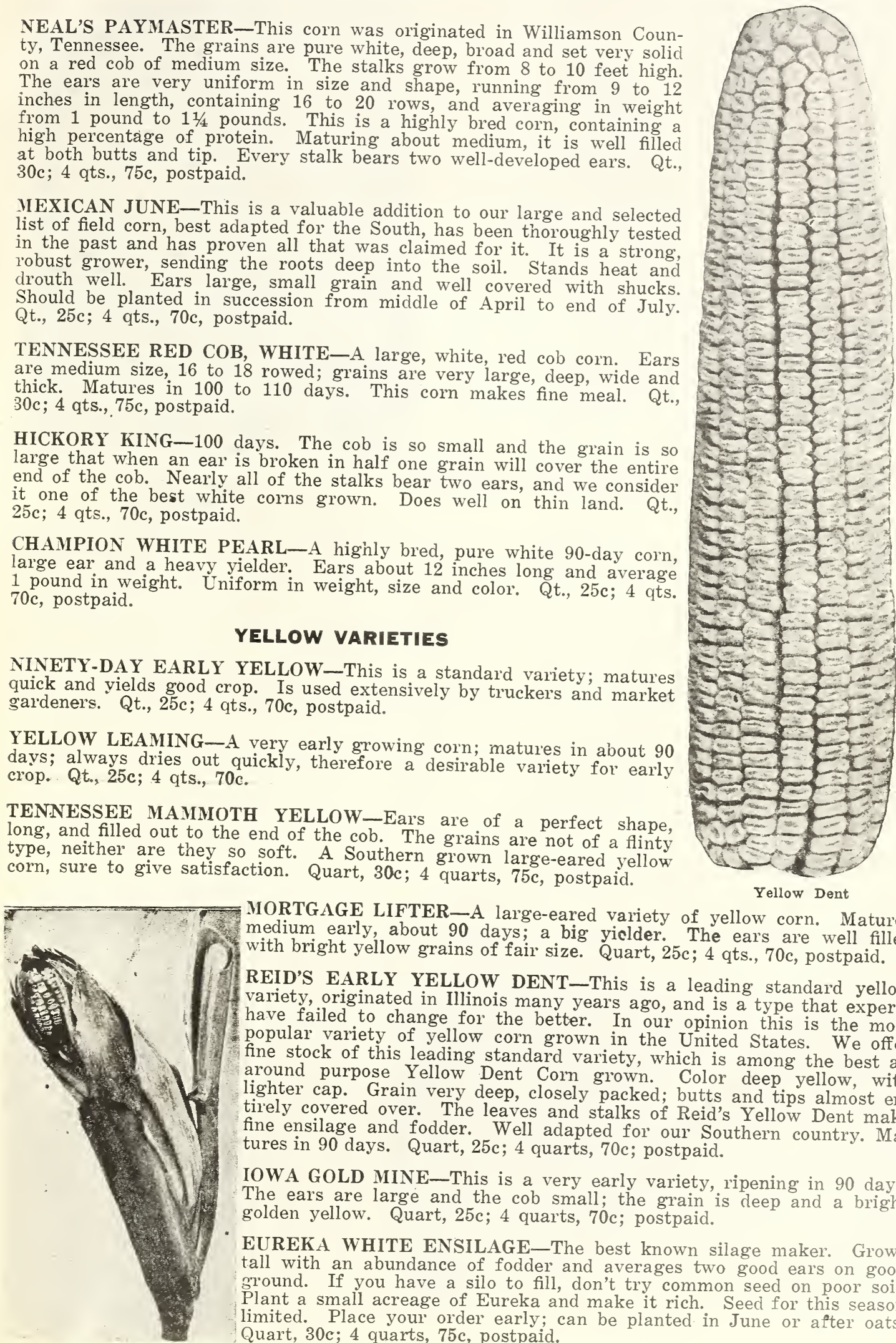

MORTGAGE LIFTER-A large-eared variety of yellow corn. Matures medium early, about 90 days; a big yiclder. The ears are well filled with bright yellow grains of fair size. Quart, $25 \mathrm{c} ; 4$ qts., $70 \mathrm{c}$, postpaid.

REID'S EARLY YELLOW DENT-This is a leading standard yellow variety, originated in Illinois many years ago, and is a type that experts have failed to change for the better. In our opinion this is the most popular variety of yellow corn grown in the United States. We offer fine stock of this leading standard variety, which is among the best all around purpose Yellow Dent Corn grown. Color deep yellow, with lighter cap. Grain very deep, closely packed; butts and tips almost entirely covered over. The leaves and stalks of Reid's Yellow Dent make fine ensilage and fodder. Well adapted for our Southern country. Matures in 90 days. Quart, 25c; 4 quarts, 70c; postpaid.

IOWA GOLD MINE-This is a very early variety, ripening in 90 days. The ears are large and the cob small; the grain is deep and a bright golden yellow. Quart, $25 \mathrm{c} ; 4$ quarts, $70 \mathrm{c}$; postpaid.

EUREKA WHITE ENSILAGE-The best known silage maker. Grows tall with an abundance of fodder and averages two good ears on good ground. If you have a silo to fill, don't try common seed on poor soil. Plant a small acreage of Eureka and make it rich. Seed for this season limited. Place your order early; can be planted in June or after oats. Quart, 30c; 4 quarts, 75c, postpaid. 


\section{SOY OR SOJA BEANS}

The Soy Bean is a legume, and in nutritive value is equal to Red Clover. As a soil improver, is it excellent. This plant will grow on a wide variety of soils, but the richer the soil the larger the yield of forage.

The land should be prepared as for cow peas, and the seed planted in drills at a sufficient distance to permit one or two cultivations. One bushel of seed will plant two or three acres, the amount depending on the distance between the rows. The planting should be shallow, never more than one
inch, or many of the seed will decay. This is a very important point to remember. Inoculation with soil from any old soy bean field is not usually necessary. If wanted for hay the crop should be cut when the upper leaves begin to turn yellow, but if wanted for seed the gathering should be delayed until nearly all the leaves have fallen. The hay is easily cured and is nearly as nutritious as Alfalfa hay. The seed planted in drills at a sufficient distance to permit cultivation, using $1 / 2$ bushel of seed per acre. It is also sown broadcast at the rate of one bushel to the acre. Soy Beans may follow a crop of rye or barley. Sowing thickly will prevent the stalks from growing too coarse, and will enable them to be harvested and cured to better ad vantage. Drill in corn rows. One peck to the acre will help the soil and make fine hog pasture.

MAMMOTH YEILOW SOY BEANS-The largest growing and most popular of Soja Beans for forage purposes. A little later in maturity than other kinds, but makes larger yields, both of forage and seed. Qt., 30c; parcel post paid.

OOTOOTAN SOY BFANS-This is the most remarkable and most valuable addition to Southern agriculture for many years. A Hawaiian bean. It is a beautiful fast growing plant growing from 4 to 5 feet high, having fine stems and delicate leaves. It cures quickly and makes a hay of fine texture and splendid quality. For hay and grain combined the Ootootan is in a class by itself. The bean itself is quite small and jet black. One-half peck plants an acre. Can be planted any time from April 1st to August 1st. Qt., 50c; parcel post paid

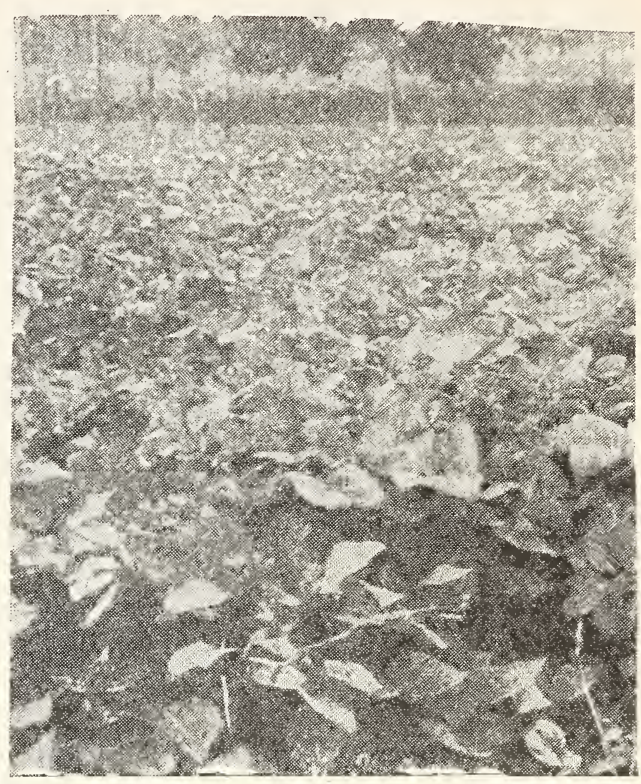

Soy or Soja Beans VELVET BEANS

BIIOXI SOY BEANS-This bean is different from all other Soys, being larger in type and usually over 6 feet high, wide branching with much foliage. This extra foliage is of great advantage for the silo, for soil re. newing, etc. Stems are large, but hollow and eure easily. Pods scatter seed very little; two weeks later than the Mammoth Yellow. A rank grower and fine for fall pasturing, seed production and planting in corn for fourths of a bushel broadcast. Price, 40c per qt., ppd.

IAREDO SOY BEANS-The new Laredo Soy Bean, after a thorough test, has proven to be the best all around Soy Bean and practically immune to root knot. The Laredo is different from any other variety. Plants get up a few inches high and stool out like oats and each indiivdual plant sends up six to fifteen very fine branches making it one of the very best hay beans. Similar in some respects to O-Too-Tan in regard to seed, however are a little smaller, black and flat. Very early. One bushel will plant about twelve acres in $2 \frac{1}{3}$ foot rows, 3 to 4 seeds to the foot in drills so the cost per acre is not so high in comparison to the other Soys; 1 quart $75 c_{i}$ postpaid.

See Page 50 for quantity-price on above.

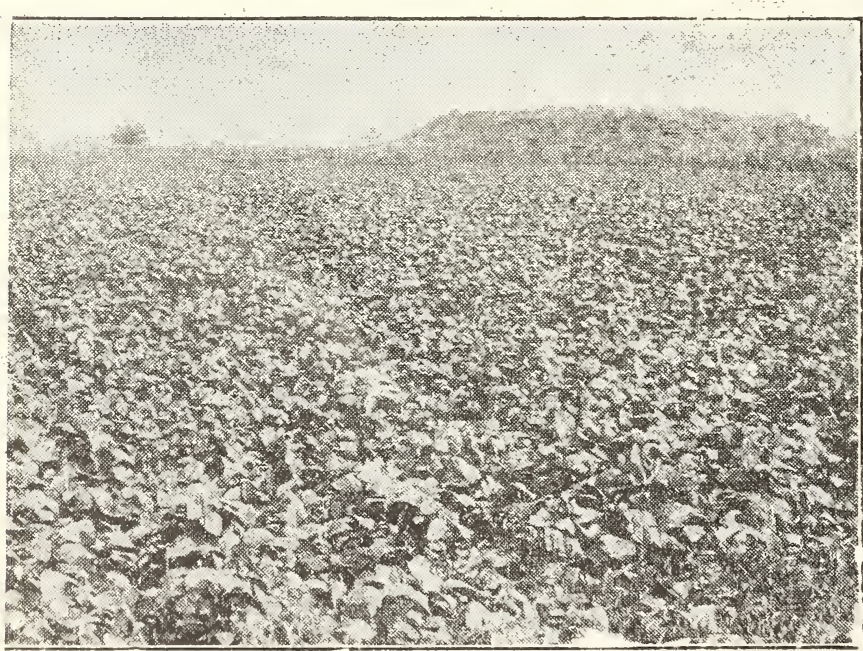

A Field of Velvet Beans
Velvet Beans make an enormous growth of vines greater, in fact, than any other known forage plant, in the same length of time, far surpassing the cow pea in yield. Velvet Beans are usually planted in rows 4 or 5 fieet apart, at the rate of about half a bushel per acre. As a soil improver they are considered superior to cow peas, as they make so much larger growth and so much heavier amount of foliage. 'The proportion of nitrogen contained in the vines is about the same as in cow peas, and as the yield is so much greater, the total amounts of nitrogen and humus added to the soil are correspondingly larger. A crop of three tons will add as much nitrogen to the soil as will a ton of cottonseed meal, whit.

FARIY BIRD SPECKLED-This early speckled Velvet Bean is a variety that matures in 90 to 100 days, and can be grown in almost any part of the South. The Early Bird Pean may be planted in April or May, in the drill with corn, or in rows close to the corn, preferably after a rain, and cover shallow. The cultivation of the corn does the rest. The beans will begin to October 1st, or before frost in any section of the South ern states. 1 quart, $30 \mathrm{c}$, postpaid.

OSCEOIA_This new velvet bean has several advantages over the early speckled varieties. It is free from the stinging fuzz or velvet on the pods, which makes the other varieties very unpleasant to handle. It has larger beans and pods, making them less expensive to gather, and is also much earlier than most of the other beans. It is two weeks earlier than the 100-day. Commences to get ripe about September 1st, and largely ripened by September 15th; all ripo last September. Will make 25 per cent more beans than the 100-day. Blooms mostly purple. 1 qt., $35 \mathrm{c}$; postpaid. GFORGIA BUSH VEIVIT BEANSrows up and stands sturdily as a bush, dis tinct entirely from the twining variety. The upright busli grows $31 / 2$ feet high with linubs i)ranching from the bottom. Planted in the widdle of 5 -foot corn rows, it fills the whole middle and does not interfere or strangle the corn. Can be grown for hay and the seed sown braodcast up to June 1, makes three times as much hay as cow peas. Also fine the vining varieties. The seed is a little smaller and darker than the seed of the 100-day Speckled Velvet Bean. The pods are a littl shorter and they have no sting whatever. bushel broadcast per acre in May or Jnne. In the corn plant about April 15. After the corn is up, in the middles about one-half peck per acre. Price. qt., 50c, postpaid. mature in July and will about have finished maturing for winter grazing. Stock like it better than 


\section{MILLET}

Millet makes a large-yielding and most nutritious hay crop, quick growing and easily cured. It, how ever, requires to be seeded thickly- not less than 1 bushel per acre and the crop should always be cut while in bloom, before seed hardens in the head. If the seed is allowed to form the stalks get hard and it does not make nearly as good hay, and at the same time is more exhaustible to the land. Can be sown any time from the middle of April to the end of Juiy. Do not sow too early.

TENNISSEE GOIDEN-Our Southern grown millet makes much better growth than the Western grown seed. This true Tennessee grown, a type that produces better quality, grows taller and gives a larger vield of very nutritious hav, is a quick grower. It should be cut for hav when it begins to show the heads. Plant $1 \frac{1 / 2}{2}$ to 2 bushels an acre broadcast. Plant from April to August. The sowing of Southern Millet with cowpeas for a hay crop is increasing in favor each year. Then this is done, use an early variety, such as Whippoorwill or New Era, sowing about $3-4$ to a bushel of millet with on bushel of Peas to an acre. Lb., 20c; postpaid.

WESTERN GOLDIN-This variety is very similar to the Tennessee Golden; however, it does not pro. duce quite as much hay, and the heads are not quite so large. Lb., $20 \mathrm{c}$; postpaid.

F'EARI, OR CAT-TAII-Is largely used by dairy. men. Furnishing them green food throughout the summer. Should not be planted before May in warm soils, as it is a tropical plant. when it has reached the height of three to four feet, it will stool out enormously and make a rapid growth. "In this way or 4 cuttings a season can be obtained. It can be fed either green or cured as dried forage, making a most nutritious feed which is relished by all kinds of stock. Sow 5 pounds per acre in drills 3 feet apart or broadcast at the rate of 20 to 30 pounds per acre. Lb.; $35 \mathrm{c}$; parcel post paid.

JAPANESE, OR BARNYARD IMIIET-This is a forage plant of great value, growing in most any soil. It has been known to produce 3 to 5 tons of fodder if planted early. After second cutting it will afford a pasturage all the fall. It is relished by all stock, and is sometimes called the Billion Dollar Grass. 1 lb. $30 c$ postpaid.

\section{KAFFIR CORN, MILO MAIZE}

WHITE KAFFIR-Grows 4 to 5 feet hihg. The stems are very leafy and keep green and brittle, unlike other sorghums, which harden. Makes excellent fodder, either green or dried. For fodder, sow from $1 / 2$ to 1 bushel, either broadcast or in drills: Lb., $25 \mathrm{c}$, postpaid.
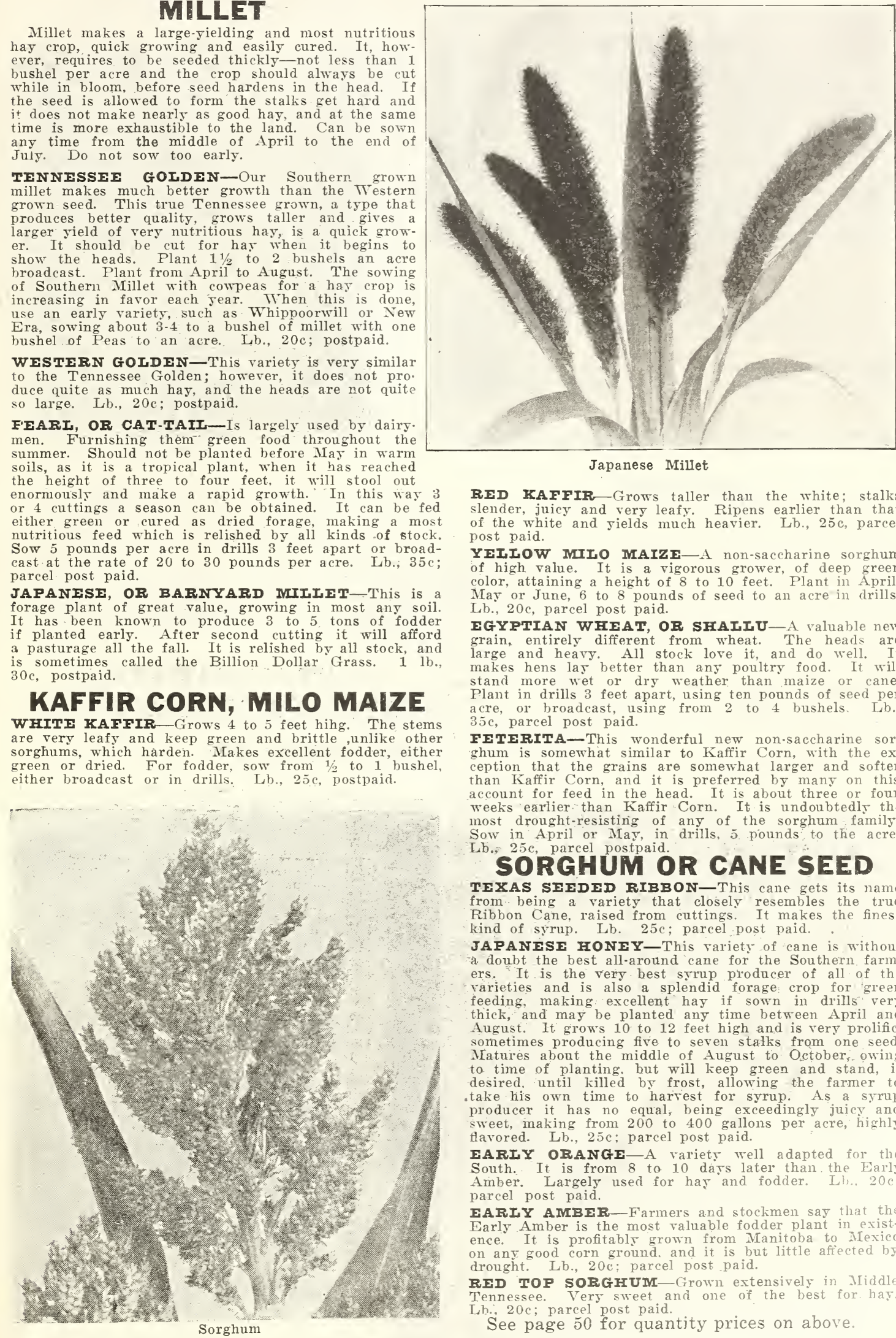

RED KAFFIR-Grows taller than the white; stalks slender, juicy and very leafy. Ripens earlier than that of the white and yields much heavier. Lb., $25 \mathrm{c}$, parcel post paid.

YEIIOW MIIO MAIZE-A non-saccharine sorghum of high value. It is a vigorous grower, of deep green color, attaining a height of 8 to 10 feet. Plant in April, May or June, 6 to 8 pounds of seed to an acre in drills. L.b., $20 \mathrm{c}$, parcel post paid.

IGYPTIAN WHEAT, OR SFAIIU-A valuable new grain, entirely different from wheat. The heads are large and heavy. All stock love it, and do well. It makes hens lay better than any poultry food. It will stand more wet or dry weather than maize or cane. Plant in drills 3 feet apart, using ten pounds of seed per acre, or broadcast, using from 2 to 4 bushels. Lb. $35 \mathrm{c}$, parcel post paid.

FETERTA-This wonderful new non.saccharine sorghum is somewhat similar to Kaffir Corn, with the exception that the grains are somewhat larger and softer than Kaffir Corn, and it is preferred by many on this account for feed in the head. It is about three or four weeks earlier than Kaffir Corn. It is undoubtedly the most drought-resisting of any of the sorghum family. Sow in April or May, in drills, 5 pounds to the acre.

\section{SORGHUM OR CANE SEED}

TEXAS SEIDED RIBBON-This cane gets its nam from being a variety that closely resembles the true Ribbon Cane, raised from cuttings. It makes the finest kind of syrup. Lb. $25 \mathrm{c}$; parcel post paid.

JAPANESE HONEY-This rariety of cane is without a. doubt the best all-around cane for the Southern farm ers. It is the very best strup producer of all of the varieties and is also a splendid forage crop for green feeding, making excellent hay if sown in drills very thick, and may be planted any time between April and August. It grows 10 to 12 feet high and is very prolific, sometimes producing five to seven stalks from one seed. Matures about the middle of August to October . owing to time of planting, but will keep green and stand, if desired, until killed by frost, allowing the farmer to take his own time to harrest for syrup. As a syrup producer it has no equal, being exceedingly juicy and sweet, making from 200 to 400 gallons per acre, highly flavored. Lb., 25c; parcel post paid.

EARIY ORANGE-A varietr well adapted for the South. It is from 8 to 10 dars later than. the Early Amber. Largely used for hay and fodder. parcel post paid.

FARIY AIMFR-Farmers and stockmen say that the Early Amber is the most valuable fodder plant ence. It is profitably grown from Manitoba to Mexico on any good corn ground. and it is but little afiected b drought. Lb., 20c: parcel post paid.

RED TOP SORGHUM-Grown extensively in Middle Tennessee. Very sweet and one of the best for hay. L... 20c; parcel post paid.

See page 50 for quantity prices on above. 


\section{PEANUTS}

Prepare the ground well, laying it off in rows with a shovel plow; the rows should be $3 \frac{1}{2}$ feet apart, and put two kernels to the hill, which are about one foot apart. Cultivate thoroughly and keep the land as level as possible. One and one-half bushels of unshelled nuts will seed an acre.

SPANISH-In addition to their value for growing for nuts. these are very largely used in the South as a forage and fattening crop for hogs and other stock. They are early to mature, very productive, and in the far South, where they can be planted during March and April, two crops can be made in one year, the second crop being planted early ix July, the tops making a hay crop and the nuts a grain crop. They grow more compact than the Virginia Peanuts, making it possible to grow them closer, making the cultivation easier also. This variety frequently yields sixty bushels of marketable peanuts and two tons of hay per acre. Lb., $25 \mathrm{c}$, postpaid.

TENNESSER RED-The finest variety grown. Especially adapted to the black, waxy land as well as the sandy soil. The nuts contain three large kernels in each and are enormously productive. Lb., $30 \mathrm{c}$, parcel post paid.

MAMMOTH WHITE VIRGINIA-Largest size; white variety. Lb., $30 \mathrm{c}$, postpaid.

\section{COW PEAS}

Sow in May, June and July, at the rate of one-half bushel to the acre. The value of cow peas as a soil enricher is now well known. As fast as farmers under stand the advantages of this plant as an agency through which the value of their land may be greatly increased, there will be more successful farmers and more profitable farms. It adds nitrogen to the soil at less cost than any other method, Cow peas make excellent hay.

Prices on cow peas given on application. Let us know how many you will need.

WHIPPOORWIII-A favorite early bunch-growing variety. Seed is reddish brown speckled. A great favorite on account of its early maturity.

NEW ERA-An early, upright-growing variety. The seed is smaller. It is not inclined to run. Matures in sixty to seventy-five days.

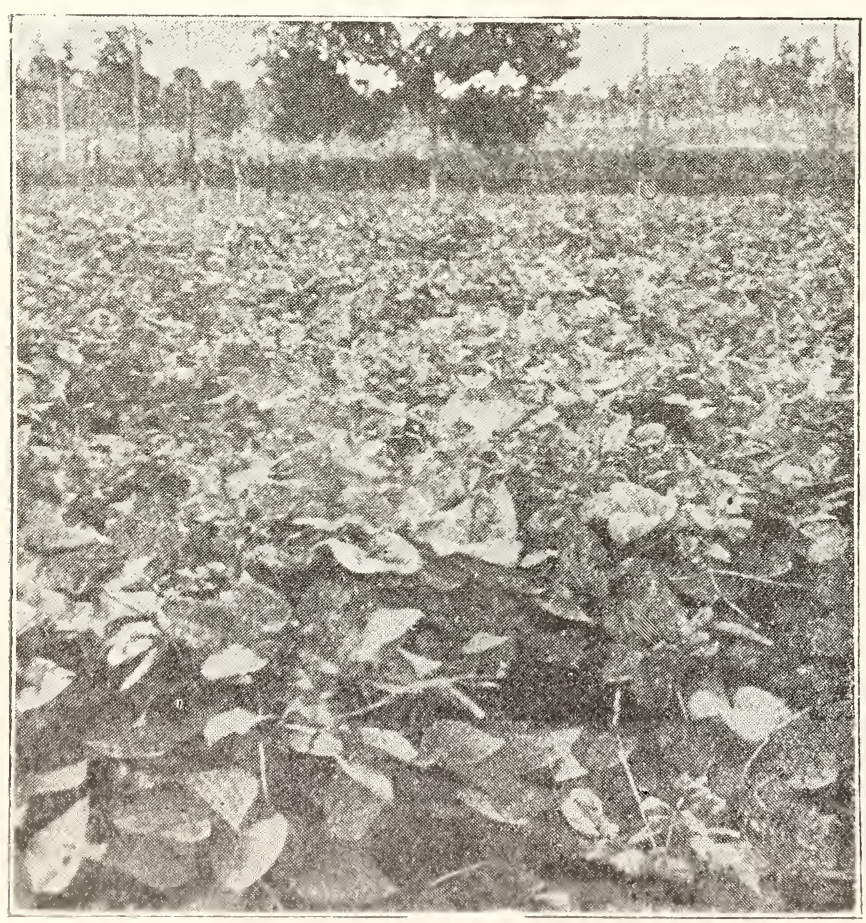

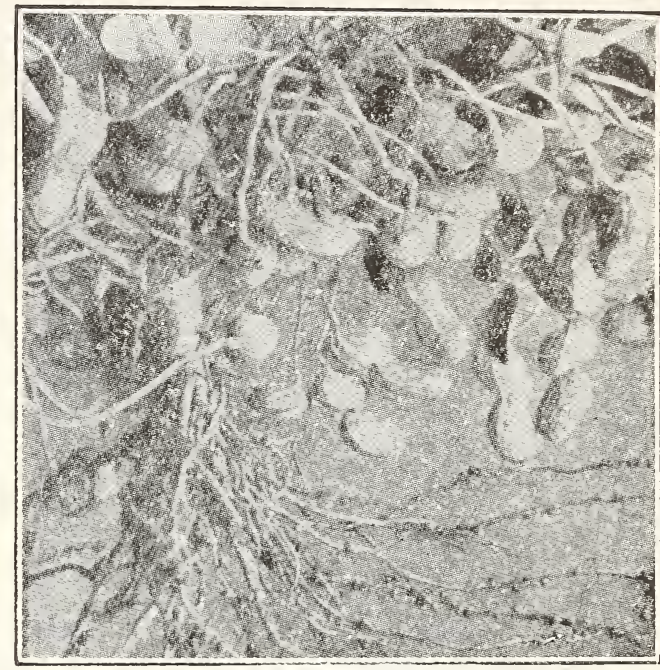

Spanish Peanuts
BIACK STOCK-This is a large, late-vining variety. The vines grow very long. Best for thin land.

CIAY-Very similar to the Unknown but earlier; vigorous growth; very popular.

RED RIPPERS-One of the most prolific varieties of cow peas. Vines grow long; make an abundance of hay MIXID-Preferred by many farmers where the crop is intended for soil improving; they will grow thicker than separate varieties, producing better crop of vines and forage.

\section{WHITE TABLE PEAS}

CAIIFORNIA IARGE WHITI BIACKIYE-Very large, kidney-shaped peas, maturing the earliest of all fine for early market. Qt., $40 \mathrm{c}$, postpaid.

WHITI BROWN-EXED-A desirable table pea. Pro lific. Qt., 35c, postpaid.

WHITE IADY PEAS-Very small seeded but strong growing and prolific pea for table use. Peas are creamy white and of the finest quality. Qt., 50c, postpaid.

CROWDFR PEAS-Exceptionally fine for table use. Prolific and very sweet. Qt., 60c postpaid.

MUNG BEAN-Wonderful new bean for for age. Heavy seeder, grows well on light or clay soils, produces tremendous quantity of nitrogen nodules on its roots. Beans are excellent for table use. Matures in 90 to 100 days, a little earlier than speckled pea, but can be planted at any time and the same way as cow peas. Plant grows upright like soja bean. making it easy to cut with blade or machine. Leaves stay on stalk well while being handled. $1 \mathrm{lb}, 50 \mathrm{c}$, postpaid.

CANADA FIFID PEAS-Every year there is more inquiry for field peas. As a fertilizer they come next to clover, to be plowed under when they commence to blossom. They will grow on land that will not produce clover. Sow $11 / 2$ to 2 bushels to the acre; or, if with oats sow 1 bushel of each. Qt., $40 \mathrm{c}$, postpaid.

CASTOR BEANS (Ricinus or Castor Oil Bean)-Plant like corn, in March and April use $1 / 2$ peck of seed to the acre in rows 4 feet apart; thin plants to 24 inches. The plant prefer. a rich, well drained sandy or clay loam. Qt. 55c, postpaid.

See pages 44,45 and 46 for complete list of Poultry Supplies at reasonable prices. 


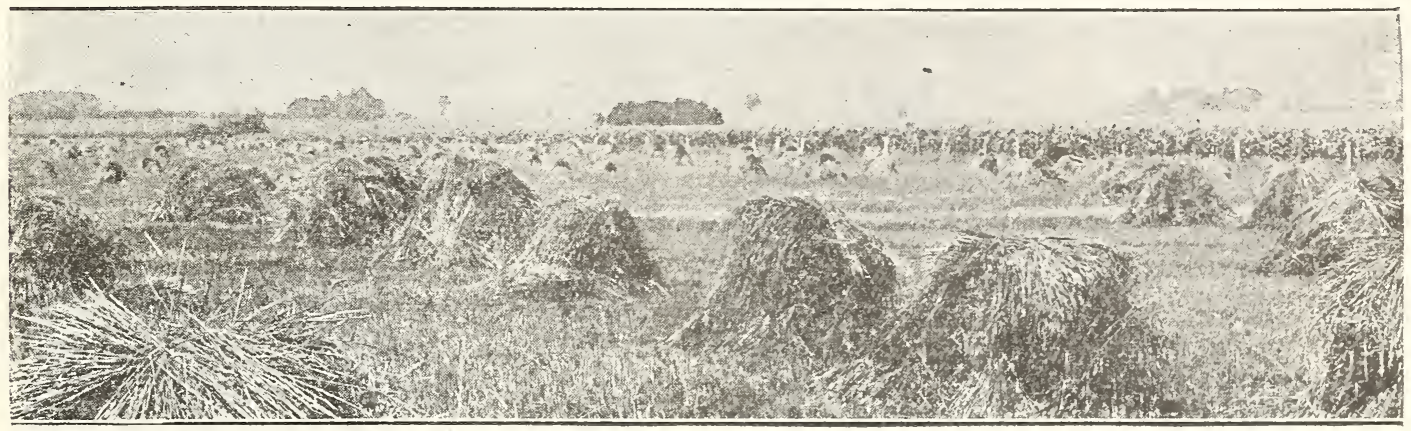

\section{Miscellaneous Farm Seeds}

We have grouped together for the convenience of our customers all the various farm seeds. If larger quantities are wanted than prices quoted call for, we will be pleased to quote further upon request. EARIY BURT OATS-The quickest growing, most
prolific and surest cropping of Spring Oats. Good for thin land. Sow 2 bushels to acre.

RED RUST PROOF OATS-These oats are very popular throughout the South. They do well on any good land and are very productive. They are sown both in the spring and fall at rate of 2 bushels to acre. JAPANESE BUCKWHEAT-Sow in April, May or June, 1 bushel broadeast to the acre. 1 lb., $25 \mathrm{c}$, postpaid.

SIIVER HUII BUCKWHEATSplendid for bees, also makes best grain. Sow in June, 1 bushel, broad. cast, to the acre. 1 lb., $25 \mathrm{c}$, postpaid. IMP. EVERGREFN BROOM CORN -A favorite in all sections. Grows to. a good length and, if cut at the proper time, retains a good color. Six pounds of seed are required for an acre when drilled in rows 3 feet apart. 1 lo 250, postpaid.

DWARF OKIAHOMA BRO OM CORN-This variety grows only 3 or 4 feet high, and is much easier han. dled than the tall growing sorts. The bush is straight smooth and of good quality. 1 lb., $25 \mathrm{c}$, postpaid.

SPRING VETCH-Better for spring sowing than the Winter Vetch. A nutritious and valuable forage and soil-im proving crop. Large and quick growth. Sow $50 \mathrm{lbs}$. to the acre. $1 \mathrm{lb}, 30 \mathrm{c}$, postpaid.

SAND OR HAIRY VETCH-SOW from July to November, preferably with grain, which will hold vetch off the ground. Sow 50 lbs. to the acre. With grain, 1 peck to the acre. 1 lb., $40 \mathrm{c}$, postpaid.

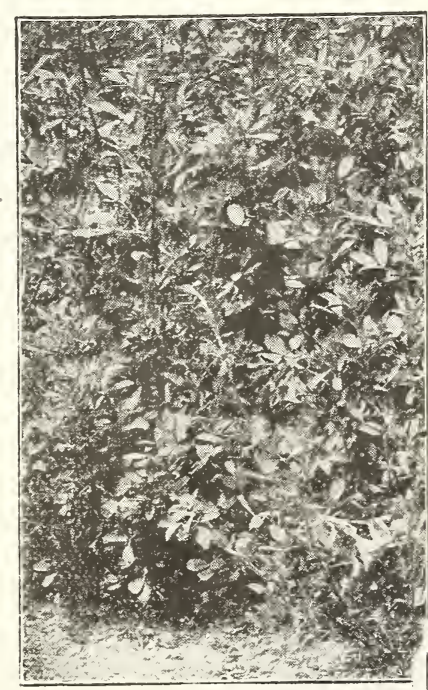

$\nabla$ etch
APPIER OATS-A very hardy variety, rust proof and a heavy yielder. Matures ten days earlier than native rust proof and about a week later than Burt.

WINTFR TURF OATS-This oat is unsuited for spring planting. They are best planted in the fall and will furnish excellent winter and spring pasture.

SPEITZ OR FMIMER-Matures as early as Bariley and grows as tall as Rye, but is of better feeding value than either. It is tough and hardy and stands drouth better than any other grain. Sow in March, 1 bushel to the acre, broadcast. 1 lb., $25 \mathrm{c}$, postpaid.

BFARDIESS BARTEY-It makes a quick growing crop of most excellent and nutritious feed, either to use green or to cure as hay. Sow $1 \frac{1 / 2}{2}$ to 2 bush els per acre. 1 lb., 20c, postpaid.

RUSSIAN SUNFIOWER-Plant in March, April and May, 6 pounds of seed to the acre, making rows $3 \frac{1}{2}$ feet apart, dropping 2 seeds every 18 inches; cultivate like corn. 1 lb., 25c, postpaid. TEOSINTE-A valuable continuous cutting forage plant for Southern and Southwestern States, furnishing a most nutritious food, green or dry, for horses and cattle. It resembles Indian Corn, the leaves being larger and the sap sweeter. Sow in May or June, in drills, $31 / 2$ to 4 feet; 2 to 3 lbs. per acre. $1 / 1$ lb., 35c; 1 lb., $85 \mathrm{c} ; 5$ lbs., $\$ 3.70$, postpaid. Not prepaid, 1 lb., 75e; 5 lbs., $\$ 3.50$.

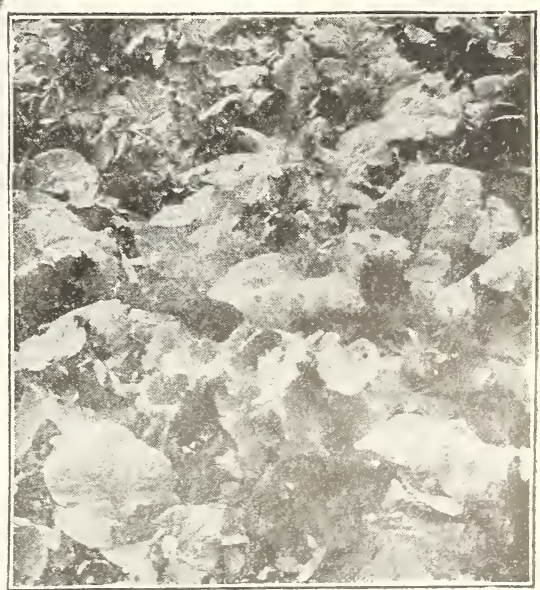

RAPE, DWARF ESSEX-This is an ideal sheep feed, easily grown perfectly hardy and possesses remarkable fattening properties. Any corn soil will grow rape. Sow the seed any time in March and by the end of June, and the crop can be ready to feed at a season when it is most needed. It does well sown with oats. Ofter oats are cut the Rape grows rapidly. If the soil is rich and clean, sow broadcast; if not so clean, sow in drills and cultivate as for corn. When sown broadcast use
postpaid.

SEID RYE-Makes excellent pasture for all classes of stock. Sown mostly in the fall, beginning about September and sowing up to December. We handle three varieties-Missouri, Abruzzi and Rosen. Prices quoted on application; also any other information.

CFUFAS-Much used to fatten hogs. Plant in April, 12 inches apart in 3-foot rows. Should be soaked before planting. One peck of seed per acre. Lb., 50c, parcel post paid.
Essex Rape 


\section{Fruit Trees, Berries, Grape Vines and Shrubs}

Our trees are first-class in every respect. We represent one of the largest and most reliable nurseries in the South.

Terms are strictly cash, F. O. B. growing station. No trees shipped C. O. D.

Set out small trees. They are more certain to grow and will bear fruit just as early as any large or older tree. It is a mistake to reset any. trees older than two years.

\section{APPLES}

2-year-old Trees _._._._._._Each, $70 \mathrm{c} ; 10$ for $\$ 6.00$ SUMMER VARIETIES

Duchess of Oldenburg-Yellow, striped red. July.

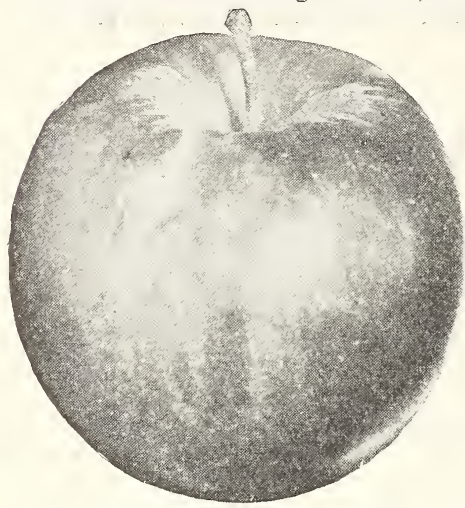
Early Harvest Fine yellow: rip ens in June.

Horse - Large, yellow, fine for cooking; ripens in August.

May Pippin - Is greenish yellow: ripens in May and June.

Red Astrachan Greenish, covered crimson; rip. ens in June. Red June-Dark c r i m s o n, fine grain, moderately juicy.

FALL

VARIETIES

Bell Flower-Oblong, fine rich yellow, juicy, acid. Fall Pippin-Large, yellow; ripens in September. Rome Beauty-Large, red; white flesh.

Yates' Mammoth-Richly striped; ripens in November. WINTER VARIETIES

Arkansas Beauty-Large, bright red; succeeds well. Arkansas Black-Large, dark crimson; flesh yellow. Ben Davis-Large, greenish yellow, striped with red. Grimes Golden--Golden yellow, crisp, tender, juicy. Jonathan-Large size; rich color, handsome variety. Winesap-Rich, dark red, flesh fine, creamy yellow. Staymen Winesap-Similar to Winesap, better quality. Delicious-Very large, oblong, rich crimson, shaded to yellow.

\section{CRAB APPLES}

Each_____ $\$$.75. Ten ______ $\$ 6.50$

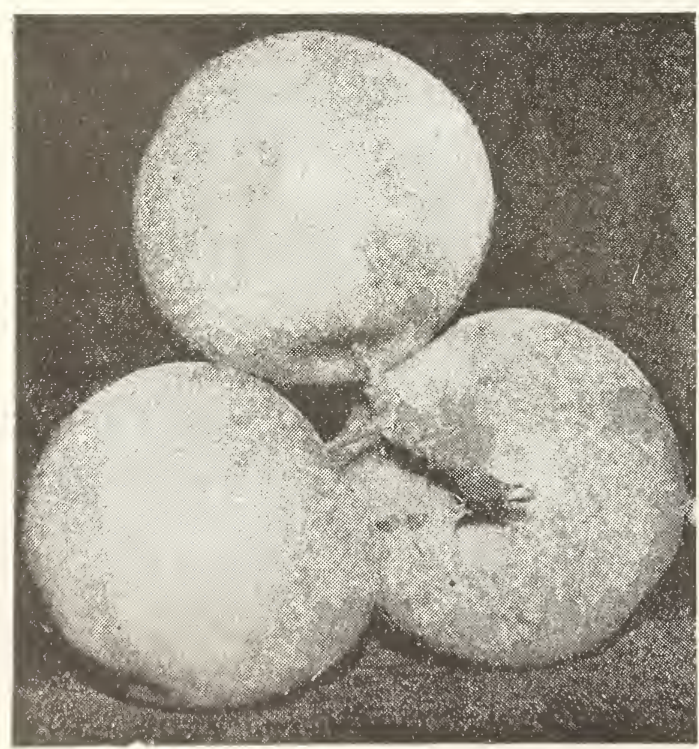

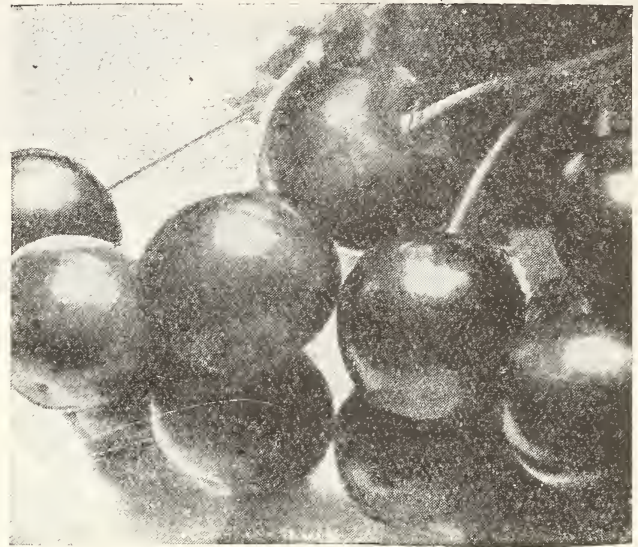

Early Richmond

\section{CHERRIES}

2-year-old Trees _..._._._._each $\$ 1.00 ; 10$ for $\$ 8.50$

Black Tartarian-Black, juicy; ripens last of June.

Early Richmond-Fine, very early; ripens in May.

Governor Wood-Very large; ripens last of May.

Late Duke-Light red; ripens last of June.

May Duke-Large, dark red; ripens in May.

\section{JAPANESE PERSIMMONS}

The Japanese Persimmon is thoroughls adapted to the Cotton Belt. The fruit varies in color and shape. We offer two of the best kinds, well adapted to this latitude, in four distinct sorts. Price, 2 to 4 feet, each $\$ 1.00$; ten for $\$ 9.00$

\section{NECTARINES}

Strong 2-year-old trees_.___._._each $75 \mathrm{c} ; 10$ for $\$ 7.00$

\section{PEACHES}

2-year-old Trees _..._._._._._each $\$ .70 ; 10$ for $\$ 6.00$

\section{CLINGSTONES}

Chinese Cling-Creamy white; ripens July 15.

Fitzhugh Lee-Creamy white, crimson blush; July.

Heath Cling-Pale yellow, fine; ripens September.

Indian Blood-Large, dark crimson; ripens August.

Lemon Cling -A

deep yellow; rip

ens end of July.

Levy's Late - A

fine, large late

variety; ripens in

October.

Morris OctoberOne of the best; ripens October 1 . old Mixon Cling - Yellowis h white; ripens in August.

FREESTONES

Admiral Dewey-

Orange yellow,

crimson $\mathrm{ch}$ e e $\mathrm{k}$,

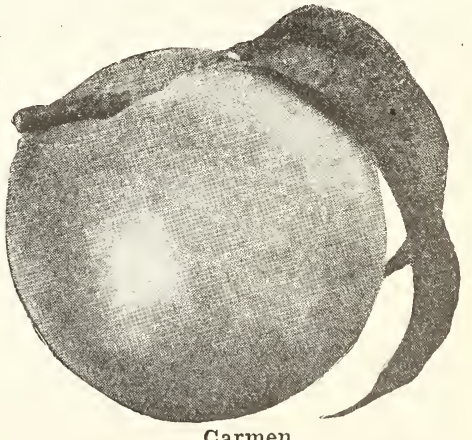

Carmen

June 15.

Belle of Georgia-Large white; ripens July 20

Carmen-Freestone; ripens in June; large.

Crawford's Early-Yellow, juicy; ripens August.

Crawford's Late-Finest quality; ripens August 20.

Flberta-Flesh

Greensboro-Early variety, large white; ripens June 15.

Heath Free-Very tender, juicy and melting; September.

old Mixon Free-Yellowish white; ripens August 15.

Piquet's Late-Flesh yellow, sweet; ripens September.

Yellow St. John-Golden vellow: ripens June 20. 


\section{APRICOTS}

Strong 2-year-old Trees ______each $\$ 1.00 ; 10$ for $\$ 8.50$ Early Golden-Small, pale orange, juicy and sweet. Moorfpark-Medium size, good keeper.

Russian-Of best quality, ripens early; very productive.

\section{PLUNG}

2-year-old Trees Abundance-Large, sweet, juicy; very early, bright red. Burbank-Large, clear, cherry red, very sweet. Damson-Bluish purple, fine for cooking; ripens in Aug. Red June-Purplish red, flesh yellow, solid, juicy. Wild Goose-Very large and fine; ripens in June.

Wickson-Purple red, firm, sweet and juicy.

\section{FIG BUSHES}

Price either variety, 1-yr.-old trees, each $\$ 1 ; 10$ for $\$ 8.50$ Brown Turkey-Medium size, very sweet, prolific, hardy Celestial-Tery large, violet, good and productive. Lemon-A beautiful lemon-colored fig, very sweet.

\section{STANDARD PEARS}

2-year-old Trees Bartlett-Yellow, faint blush; ripens in August

Clapp's Favorite-Resembles Bartlett; ripens in August. Duchess D'Angouleme-Very large; ripens in October. Garber-Larger than Keiffer; beautiful yellow.

Koonce-Of large size and good form and color.

Keiffer-Grolden vellow tinged with red on one side remarkably free from blight; ripens in September.

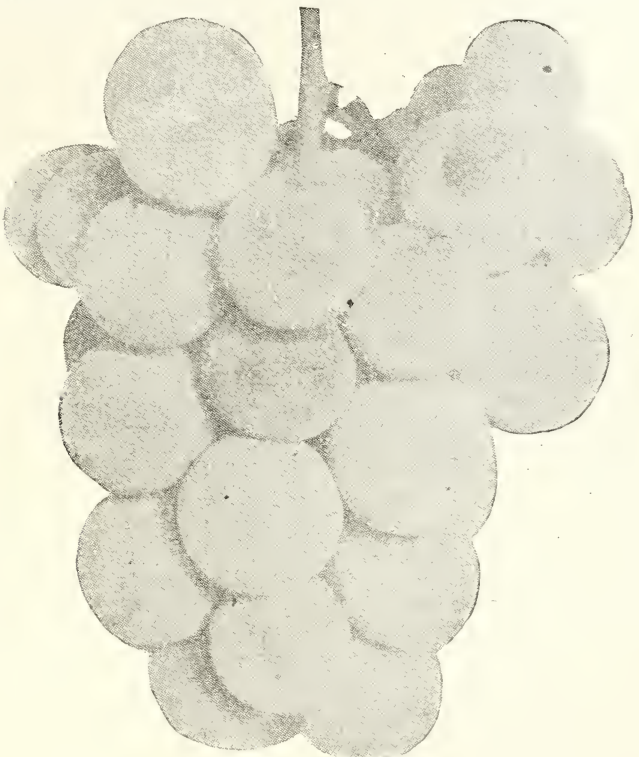

\section{QUINCES}

Strong 2-year-old Trees _...-_each $\$ 1.00 ; 10$ for $\$ 9.00$ Champion-Large and handsome; tender and rich in Orange-Large, round, golden vellow; very fine.

Rea's Mammoth-An improvement upon the Orange; much larger.

flavor.

\section{GRAFTED OR BUDDED PECANS}

The budded or grafted pecan will bear at six years of age, while the seedlings seldom commence to give fruit under ten rears after planting. Price, 2 to 3 feet, $\$ 1.50$ each, ten for $\$ 12.50 ; 3$ to 4 feet $\$ 2.00$ each, ten for $\$ 17.50$.

Bradley Pecan-Its good points are large size, thin shell, well filled and very prolific.

Frotscher Paper Shell Pecan-One of the best; large, thin shells; prolific bearing.

Pride of the Coast-Nuts frequently 2 inches in length: shell moderately thin; nuts will run from 24 to 32 to the pound.

\section{SCUPPERNONG GRAPES}

Scuppernong Grapes-Bunches seldom ever composed of more than 8 or 10 berries; berries round, of a bronze color, when full ripe; vine is free from all diseases and attacks of insects. 2-year, each $\$ 1.00 ; 10$ for $\$ 9.00$.

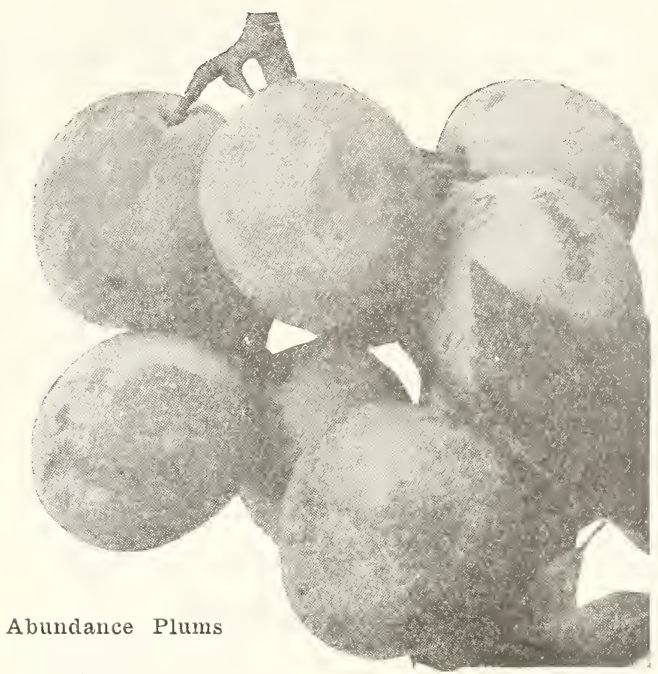

\section{GRAPES}

Strong 2-year-old vines: Price, by express, each $40 \mathrm{c}$; 10 for $\$ 3.50$.

Brighton-Large, coppery red; best quality.

Delaware-Bunches sniall and compact; light red.

Moore's Early-Large, black, earlier than Concord: fine.

Niagara-Berries large, sweet, greenish white.

Worden-Concord type, large in bunch and berry.

Concord-Large, black, juicy; sweet when ripe,

Lutic-Tery early, large red; free from rot.

Campbell's Early-Large, compact, black berry

Early Ohio-The earliest black grape; bunclies large.

\section{STRAWBERRIES}

Plant in February, Marcl, April and Norember. on good ground deeply worked and well manured. Set in rows $31 / 2$ feet apart, 15 inches in rows, for field culture 15 inches each way for garden. Cultivate clean. mulch late in the fall and uncover early in the spring. Remove mulch after fruiting and spade in a light dressing of manuce.

Any of the fol. lowing varieties: 50 for $60 \mathrm{c} ; 100$ for $90 \mathrm{c} ; 500$ for $\$ 2.75$, $1,000, \$ 4.85$; parcel post paid. Not prepaid: $100,75 \mathrm{c}$; $500, \$ 2.50 ; 1,000$, $\$ 4.50 ; 2,000, \$ 8$; $5,000, \$ 17.50$.

Special p rices quoted on larger quantities.

Aroma-Large size dark red; one of the best of the best of the late sorts.

Excelsior - Extra early; high color; a vigorous grover and one of the best drought resisters.

Brandywine - A

large, highly pro-

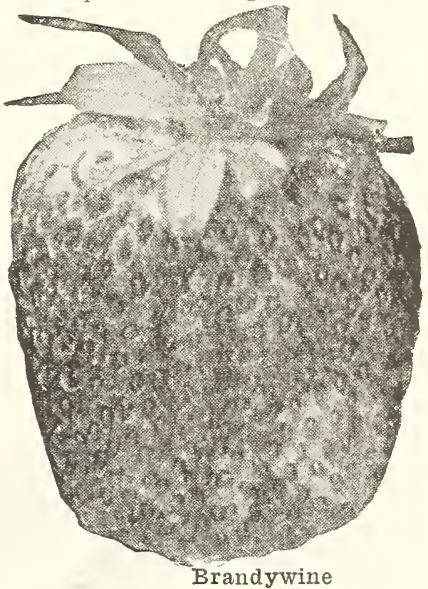

Lady Thompson-Widely planted over the whole countr. Klondyke-A shapely dark red berry of uniform size and one of the best shippers.

Lady Corneille-A new Strawberry from Louisiana; it ripens with Klondyke, but continues in bearing longer: berries large, rich, glossy red, slightly long, uniform in size and shape; rich, juicy, sweet and delicious. Gandy-The last to ripen; a large, firm, bright erimson berry of good quality.

\section{EVERBEARING STRAWBERRY PLANTS}

Progressive Everbearing-This is the best of the Ever bearing sorts; berry is dark red, good shape and quality Price: 25 for $60 \mathrm{c} ; 50, \$ 1.00 ; 100, \$ 1.45 ; 500, \$ 5.25$; parcel post paid. Not prepaid̆: $25 \mathrm{c}, 50 \mathrm{c} ; 50,90 \mathrm{c} ; 100$, $\$ 1.25 ; 500, \$ 5.00 ; 1,000, \$ 7.50$. 


\section{RASPBERRIES}

Plant in rows 5 to 6 feet apart, 2 to 4 feet in the row. Cut the tops off within a few inches of the ground when planted. After the fruit season, cut out all the old wood which bore the last crop of fruit. Pinch the vigorous young shoots several times during the summer. They will then grow stout enough to stand without staking.

Cumberland-The largest black raspberry grown; immensely productive; quality fine; ripens very early. Price, by express, 10 for $\$ 1.00 ; 100$ for $\$ 9.00$.

St. Regis Everbearing Raspberry-One of the greatest raspberries ever introduced. Plants of the St. Regis put out in the fall or early April gave ripe berries on the 20 th of June. For four weeks thereafter the yield was heavy and the canes continued to produce ripe fruit without intermission until late October. The berries were large and beautiful, firm and full flarored, to the very last. The St. Regis is the only raspberry. as far as known, that is practically sure to produce a crop of fruit the season planted. Price, by express, each, 20c; 10 for $\$ 1.50 ; 100$ for $\$ 10.00$.

Cuthbert-Fruit large, red, of excellent quality, yield very prolific; ripens middle of May, and continues for several weeks. Price, by express, 10 for $\$ 1.00 ; 100$ for $\$ 9.00$.

Gregg-Blackcap; very productive, large size, firm, black. Price, by express, 10 for $\$ 1.00 ; 100$ for $\$ 9.00$.

\section{BLACKBERRIES}

Plant in good soil, in rows 5 to 6 feet apart, and 3 to 4 feet apart in the row. After the fruiting season, or in early spring, cut out all the dead wood. Blackberries should be planted early, before the buds start. A good top dressing, of stable manure, applied annually, will be conducive to large crops. Keep the ground clean. Himalaya Giant-A mammoth late blackberry, coming after the other berries are gone, ripens over a period of several weeks, making it especially desirable for family use. Fruit large, fine quality. Price, by express, 10 for $\$ 1.25 ; 100$ for $\$ 10.00$.

Eldorado-Fruit large, roundish conical, rich glossy black; firm, juicy, sweet and excellent. Price, by express, 10 for $\$ 1.25 ; 100$ for $\$ 10.00$.

Early Harvest-The earliest good blackberry, fruits well, of excellent quality. Price, by express, 10 for $\$ 1.25$; 100 for $\$ 10.00$

\section{DEWBERRIES}

Lucretia Dewberry-The berries are far larger and incomparably better than any blackberry, and of unequaled excellence; soft, sweet and luscious throughout; of brightest glossy black color. Price, by express, 10 for $\$ 1.00$ 100 for $\$ 9.00$

\section{GOOSEBERRIES}

Downing-Large, pale green berries. Price, by express, each $50 \mathrm{c} ; 10$ for $\$ 4.00$

\section{MULBERRIES}

Price, each $\$ 1.00 ; 10$ for $\$ 9.00$.

Hick's Everbearing-Produces immense crops; splendid for poultry and hogs.

\section{HEDGE PLANTS}

Amoor River Privet-The best of the Privets for plant ing in the South. This type retains its bright green foliage almost all winter here.

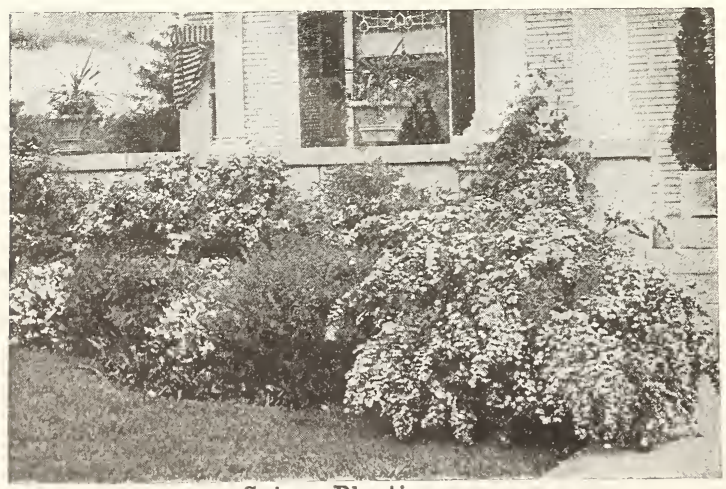

Spirea Planting

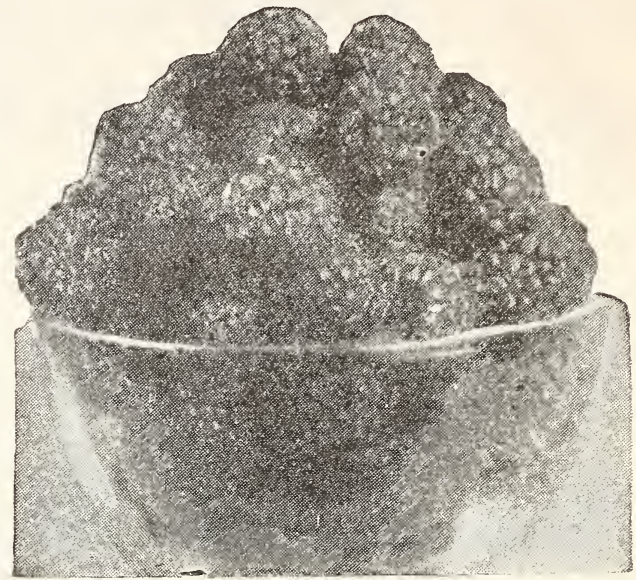

Cuthbert

Price, by express only -

12 to 15 inches 18 to 24 inches 30 to 36 inches _. California Privet-The great hedging plant. Remarkable for the beauty of its evergreen foliage and strong, regular, symmetrical growth. The foliage is dark green, very glossy and wax-like; hardy everywhere. Remove the unsightly fence and increase the value of your property by planting a California Privet Hedge. Does well in all situations and under all conditions.

Price, by express only-

12 to 15 inches 18 to 24 inches

30 to 36 inches

\section{ORNAMENTAL TREES, SHRUBS}

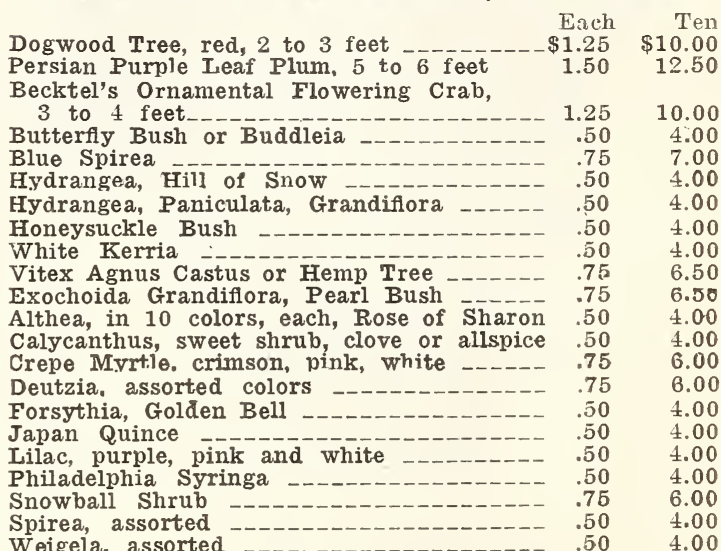

\section{SHADE TREES}

Price, Trees 4 to 6 feet, $75 \mathrm{c} ; 8$ to 10 feet, $\$ 1.00$ each.

Price, Trees 4 to 6 feet, $75 \mathrm{c} ; 8$ to 10 feet, $\$ 1.00$ each.
While Ash

$\begin{array}{lll}\text { Lombardy Poplar } & \text { Weeping Willow } & \text { Black Walnut } \\ \text { Carolina Poplar } & \text { Sugar or Rock Maple Elm, Am. White }\end{array}$

\section{EVERGREENS}

Sold only balled and baled, so will transplant safely. Ligustrum, Lucidum, Japonica, Napolense and QuihoiAmong the best of broad-leaved evergreens. Priced $\$ 1.50$ to $\$ 4.00$ according to specimen.

Chinese Arbor Vitae _. 2 to 3 ft. 1.50

Abelia Grandifiora _... 1.00

Arizona Cypress

Boxwood, green and golden

Holly-leaved Ashberry _.

Mahonia Japonica

Cape Jessamine

Magnolia Grandifiora Specimen_-4 to $5 \mathrm{ft}$. $\$ 3.00$ to 5.00

Red Cedar _. 1.00

Hemlock

Norway Spruce

Irish Juniper, small - Japonica and Variegated 


\section{Bulbs for Summer Flowering}

\section{GLADIOLUS}

This is the most brilliant and showy of all the summer flowering bulbs. Their immense spikes of gorgeous blooms comprise the most select colors and shades and many most delicate tints. They will grow in any good garden soil, as they are among the easiest and most astisfactory bulbs for everybody to grow. Start to plant the bulbs in March, continuing to do so every ten days or so for succession. Set them from two to four inches deep, according to size, and about six inches apar: each way.

SCHWABEN-Clear canary-yellow, shading to soft sulphur. Larest flower stalk and leaves of all. Planted 7 or 8 inches apart in rich soil produces wonderful blooms. Dozen, 85c; 100 for $\$ 5.75$, postpaid. Not postpaid, doz., $75 \mathrm{c} ; 100$ for $\$ 5.50$ CHICAGO WHITE-White, lavender markings in throat. Doz., $75 \mathrm{c} ; 100$ for $\$ 5.00$, postpaid. Not postpaid, doz., $65 \mathrm{c}$ 100 for $\$ 4.75$.

AMERICA-Delicate lavender-pink flowers, of large size, borne on strong stems, and well placed; splendid habit; still very popular as a cut flower variety. Doz., $60 \mathrm{c} ; 100$ for $\$ 3.75$, postpaid. Not postpaid, doz., 50c; 100 for $\$ 3.50$.

MRS. FRANCIS KING-Brilliant vermilion-scarlet. Most popular and effective variety for all occasions. Large size, Doz., 60c: 100 for $\$ 3.75$, postpaid. Not postpaid, doz., $50 \mathrm{c}$; 100 for $\$ 3.50$.

BARON J. HULOT-The leading purple variety. Doz., $\$ 1.10$; 100 for $\$ 6.75$; postpaid. Not postpaid, doz., $\$ 1.00 ; 100, \$ 6.50$ ( Not postpaid. doz., $65 \mathrm{c} ; 100$ for $\$ 4.75$.

MIXED GIADIOIUS CHIIDSII-Superb; large flowered mixed colors. Per do\%, 50c; per 100, 3.25, parcel post paid By express, doz., $40 \mathrm{c}$; per 100, $\$ 3.00$

\section{CANNAS}

No other bedding plant will give the same uniform good re sults as the Cannas. They do well in all sections of the country, and stand pre-eminently at the head of the list, sicceeding in any sumny disposition in any kind of soil, but responding more quickly to liberal treatment.

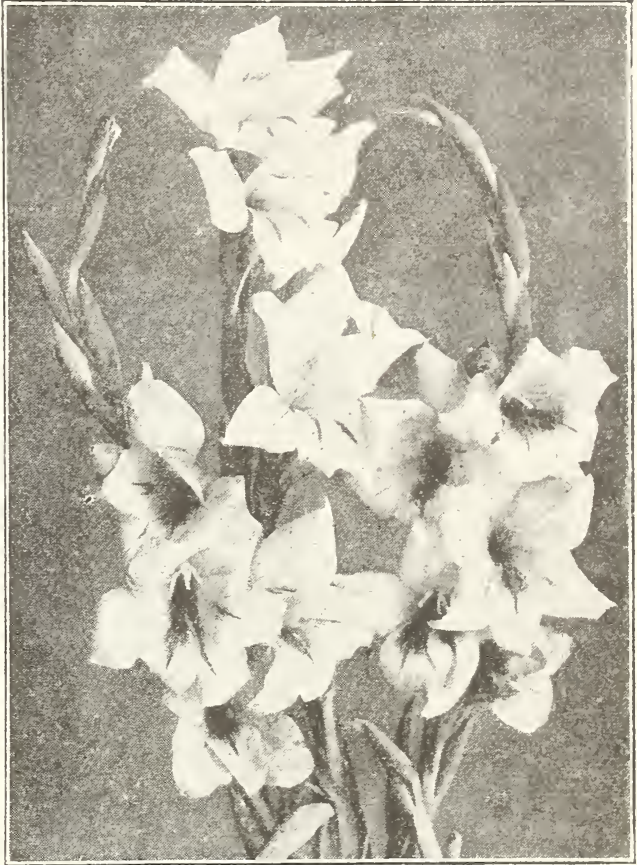

Gladiolus

MADAM CROZY-A beautiful scarlet variety with a golden yellow fringe around the edge of the petals. Very decorative. Each, 20c; dozen, $\$ 1.40$, postpaid. Not postpaid, $15 \mathrm{c}$; doz., $\$ 1.25$.

HUNGARIA-The new pink canna with green foliage, a beautiful shade of rose pink, 4 feet. Each, 20c; doz, $\$ 2.00$; postpaid. Not prepaid, each $15 \mathrm{c}$; daz., $\$ 1.75$.

EUREKA-Best white canna; large flowers; green foliage: 4 feet. Each, 25c; doz. \$2.25; postpaid Not prepaid, each, 20c; doz., $\$ 2.00$.

KING HUMBERT-Orange scarlet, bronze foliage, 4 feet. Each, 20c; doz., $\$ 2.00$, postpaid. Not prepaid, each, $15 \mathrm{c}$; doz., $\$ 1.75$

FANAI-Flowers intense brilliant fiery-red, broad pet-

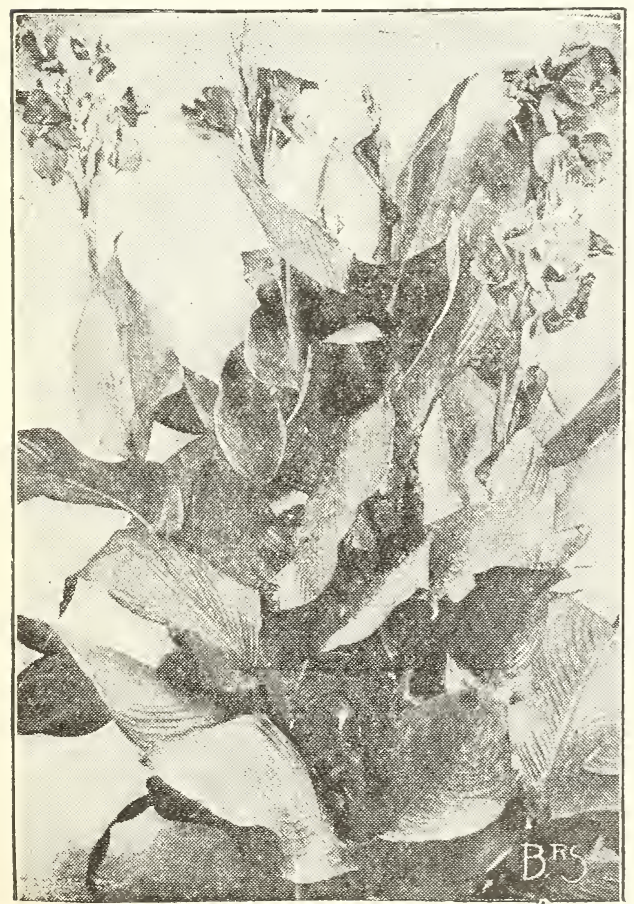

King Humbert Canna als. Foliage green, bordered brown. A strong and vigorous grower. Free early bloomer. Extra good sort. Each 20c; doz $\$ 1.40$, postpaid. Not prepaid, each, $15 \mathrm{c}$; doz. $\$ 1.25$.

NIAGARA-Height, $3 \mathrm{ft}$. Green foliage. Great handsome trusses; broad, thick durable petals. Color rich deep crimson with a wide irregular border of deep golden vellow. Each, 20c; doz., $\$ 1.40$, postpiad. Not prepaid, each 15c; doz., $\$ 1.25$.

\section{CHOICE DAHLIAS IN COLORS}

Plant bulbs in March and April, 3 feet apart. The dahlia is one of the prettiest of our summer flowers.
Double Pink
Double Purple
Double Yellow

Double White

Double Salmon

Double Scarlet

Double Striped

Each, $20 \mathrm{c}$; doz., $\$ 1.75$, postpaid. Not prepaid, each, $15 \mathrm{c}$; doz. $\$ 1.50$.

\section{TUEEROSES}

ARMSTRONG'S FVRR-BIOOMING TUBEROSF-A singl sweet-scented early blooming variety: blooms longer than the double. Doz. $60 c ; 100$ for $\$ 4.00$, postpaid. Not prepaid, doz. $50 \mathrm{c} ; 100$ for $\$ 3.75$

DOUBIE PEARL-Doz., 70, postpaid. By express, doz., $60 \mathrm{c}$ 100 for $\$ 4.00$

MADEIRA VINE-A beautiful, rapid growing climber, bearin fragrant white flowers. Each, 10c; doz., \$1.00, postpaid.

\section{PEONIES}

Ther have become indispensable in every garden. They are all hardy and admirably suited to our southern climate, growing in almost all siutations, and even flourishing under shade trees. RED, PIN K, WHITE-Each, 50c, postpaid. Not prepaid, each, $40 \mathrm{c}$; doz., $\$ 3.50$.

\section{CALADIUMS}

Caladiums are the most effective nlants in cultivation for beds, horderc, or for nlanting out upon the lawn. Small bulbs, each, $15 \mathrm{c}$; doz., \$1.25: narcel post paid. Not prepaid, by express, each, 10c: doz., $\$ 1.00$

Large bulbs, each, $25 \mathrm{c}$; doz., $\$ 2.50$, postpaid. Not prepaid, by pxpress. each. $20 \mathrm{c}$; doz.. $\$ 2.00$. 


\section{Best Bacteria for Bigger Crops, Better Soil}

Every time you plant any kind of field or garden beans, peas, clover, peanuts. vetch or alfalfa, inoculate the seed with these cul. tures of nitrogen. Unless your soil is unfavorable, having the proper bacteria on your seed often means an increases of 50 to 100 per cent in the crop yield, an even stand, and great numbers of nodules on roots which deposit in your soil nitrogen

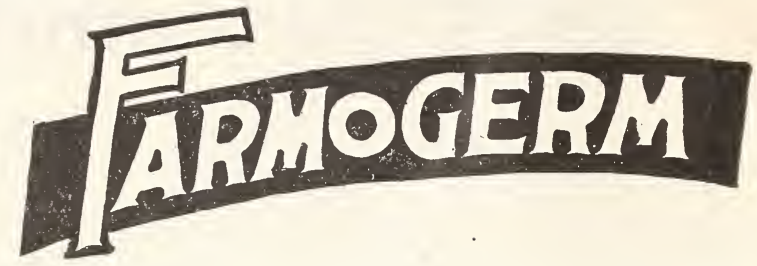
fertilizer (nitrates) worth $\$ 20$ to $\$ 30$ an acre as fertilizer for grain, cotton, tobacco, fruit or other crops grown on the land afterwards.

\section{TWO KINDS-INEXPENSIVE-EASY TO USE}

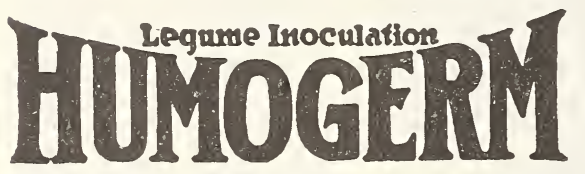

Not only is it important that you inoculate your seed, but it is just as important that you use a thoroughly reliable inoculant. Cultures are put up in two forms-either on jelly in bottles, or on soil in cans, and of the severai brands on the market we handle the best of each kind, both reasonably priced and prepared for us in laboratories that specialize on preparing the biggest result-producing bacteria. You can absolutely depend upon them. Pour on the seed and plant in usual way-directions on each container.

When you order, please state variety of seed you wish to treat. We have always fresh stock for: Alfalfa, Crimson, Sweet, White, Alsike, Hubam, Bur, Lespedeza, Japan and other clovers; Soy, Velvet, Lima and all beans; Cow Peas, Sweet Peas, Beggarweed, Sesbania, Peanuts, Vetch, etc.

FARMOGERM, in bottles, patented ventilating stopper, pure bacteria for each variety of seed. Prices, postpaid: 12 -acre size, $\$ 9.00 ; 3-\mathrm{A}, \$ 2.50 ; 1-\mathrm{A}, \$ 1.00$. A special garden ( $1 / 4$ acre) size that will inoculate $15 \mathrm{lbs}$., peas, beans, or sweet peas, $50 \mathrm{c}$.

HUMOGERM, on finely pulverized humus, in cans, sold on bushel basis. Prices, postpaid: $21 / 2$ bu. size, $\$ 2.25 ; 1$ bu., $\$ 1.00 ; 1 / 2$ bu., 60 c; $1 / 4$ bu., 35c. Special garden size that will inoculate $15 \mathrm{lbs}$. peas, beans or sweet peas, $25 \mathrm{c}$.

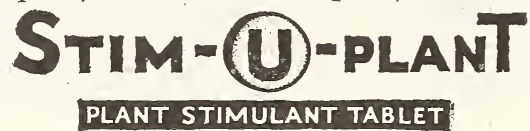

Use it and you will have the largest crops of fruit and vegetables, and an abundance of the largest and sweetest-scented flowers of intense and vivid colors. It is rich in plant food, containing 11 per cent Nitrogen, 12 per cent Phosphoric Acid and 15 per cent Potash, odorless and clean. Compare this analysis with that of other fertilizers.

Not to be thrown broadcast, but put at feeder roots of individual plants, trees, shrubs, etc.; there is no waste, you feed the plants that need it. Increases production, heightens color, improves quality. Simply insert a tablet in the soil near each plant ( $1 \mathrm{ft}$. apart if in rows) once or twice during season. Or, dissolving four tablets per gallon of water is less trouble and gives better results than the objectionable manure water. A proven success with rose growers, nurserymen, landscape gardeners, strawberry growers and gardeners. Complete directions with every package. Price, postpaid: 30 tablets, 25c; 100 size, $75 \mathrm{c} ; 1,000$ tablets, in bucket, $\$ 3.50$.

ACID PHOSPHATE - Available phosphoric acid, 16 per cent. It gives excellent results on nearly all crops, but is especially recommended for use on grains and grasses. Apply at the rate of 400 to 600 pounds to the acre, either in drills or broadcast. If broadcasted, it should be harrowed in at the time of applying so as to incorporate it well with the soil. $100 \mathrm{lbs}, \$ 2.25$, f. o. b., Vicksburg.

TRUCK GUANO-For all garden crops, beans, peas, cabbage, tomatoes, etc. Analysis: Phosphoric acid, 8 per cent; nitrogen, 4 per cent; potash, 3 per cent. 25 lbs., $\$ 1.25 ; 50$ lbs., $\$ 2.00$; 100 lbs., \$3.50, f. o. b., Vicksburg.
PURE BONE MEAL-Invaluable for top dressing lawns. Nothing is better for fertilizing young fruit trees, grape vines, roses, etc. 4 lbs., 25c; 25 lbs., $\$ 1.25 ; 50$ lbs., $\$ 2.25 ; 100$ lbs., $\$ 4.00$, f. o. b., Vicksburg.

NITRATE OF SODA-Nitrate of Soda is power. It can be used on all field and garden crops, either mixed with the soil or applied after crops are up and growing. It requires about $150 \mathrm{lbs}$. of Nitrate of Soda to the acre. Application of Nitrate of Soda not only increases the yield, but also makes crops mature earlier, and in case of drought the plants will stand the dry spell wonderfully good. 4 lbs., 25c; 25 lbs., $\$ 1.25$; 100 lbs., $\$ 4.50$, f. o. b., Vicksburg.

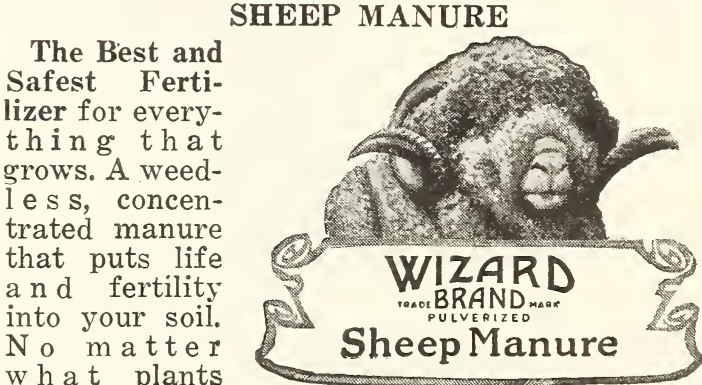
wh plants you grow, you need manure to secure best results. Wizard is far superior to chemical stimulants and stable manure. It is a real plant food that has a lasting beneficial effect on the soil. Promotes thick velvety green lawns, a wealth of vivid colored flowers in your garden and vigorous growing shrubbery. In the veg'etable garden it produces early crops of crisp tender vegetables. A highly profitable fertilizer for the florist, vegetable grower and home gardener. Prices: 5 lbs., 25c; 25 lbs., $\$ 1.00 ; 100$ lbs., $\$ 2.50$, f. o. b., Vicksburg. 


\section{Dependable Insecticides}

Spraying has now become to be an established part of the work of all farming-cotton growing, truck gardening, fruit growing, vegetable gardening and flower gardening.

Spray! Spray! Spray!-spray for insects and for fungus diseases. I believe in spraying, for I have tried and proven it. It is just as much a necessity as fertilizing and good cultivation.

Success is dependent upon the exercise of proper judgment in making applications. Know the enemy to be destroyed; know the remedies that are most effective, and finally apply them at the proper season. Be prompt, thorough and persistent.

Directions for applying the different preparations are printed on the package.

Poisonous insecticides and liquids of any kind are not permitted in the mails, so all packages of poisons, no matter how small, must be sent by express or freight at purchaser's expense.

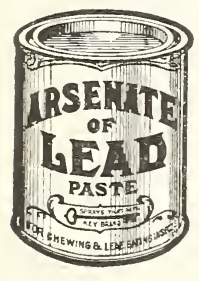

DRY ARSENATE OF LEADDoes not burn the foliage, absolutely safe to use, kills every insect that eats it, superior in every way to Paris Green, as it does not burn or scald the foliage; can be used dry as a powder or as a solution in water. Price, 1/2 lb., 30c; 1 lb., 50c; 5 lbs., $\$ 2.25 ; 10$ lbs., $\$ 4.00 ; 25$ lbs., \$8.50. Cannot be mailed.

CALCIUM ARSENATE (Powdered)-This is proper and most effective powder for dusting on cotton for eradicating the boll weevil. It is the poison used by the U. S. Department of Agriculture in experiments which proved that the boll weevil could be killed out at a profitable cost. 1 lb., 50c; 5 lbs., $\$ 2.00 ; 10$ lbs., $\$ 3.50 ; 25$ lbs., $\$ 7.25$. Cannot be mailed.

POWDERED OR DRY BORDO-The perfect dry Bordeaux mixture, all ready to be mixed, as you need it, with water; kept dry will last for years; full directions on every package how to use it. 1 lb., $45 \mathrm{c} ; 5$ lbs., $\$ 1.75 ; 10$ lbs., $\$ 3.00$; 25 lbs., $\$ 6.25$; 50 lbs., $\$ 10.50 ; 100$ lbs., $\$ 20.00$. Cannot be mailed.

PARIS GREEN-Has been on the market for many years, and is known for its effectiveness. It must be used with care; one teaspoonful to one gallon of water will be safe. 1/4 lb., 20c; $1 / 2$ lb., 30c; lb., 50c; 5 lbs., $\$ 2.25$; 100 lbs., $\$ 36.00$. Not mailable.

PYROX-Destroys insects and prevents blight all at one spraying; a combination of Bordeaux, Paris Green and Arsenate of Lead. Especially recommended for tomáto blight, etc. Lb. jar.. 50 c; 5 lbs., $\$ 1.75 ; 10$ lbs., $\$ 2.75$. Not mailable.

SCALECIDE (Pratt's)-Cures and prevents San Jose scale. One of the best dormant sprays; easy to apply; not poison. By freight only. Qt., 60 c; gal., $\$ 1.50 ; 5$ gals., $\$ 6.50$. Not mailable.

SULFOCIDE (Pratt's) - A sure preparation for the second spraying. Prevents wormy fruit; does not burn and easy to use. Directions on each can. Pt., $45 \mathrm{c}$; qt., $80 \mathrm{c}$; gal., $\$ 2.25$. Not mailable.

PARADICHLOROBENZENE-Peach tree borer control. Discovered at last, a sure cure for peach tree borer. Time of application, Sept. 25 to Oct. 31. Method of application, applied to the soil around the tree, making a little trench and then covering. The fumes descend upward, killing all the borers and other insects around the roots. Paradichlorobenzene must not be used on any trees under 5 years old, as it is very powerful and will harm young trees. No danger. in handling this wonderful discovery as it is non-poisonous to man. Price, per pound, which is enough for 16 trees, $75 \mathrm{c}$; 5 lbs., $\$ 3.00 ; 10$ lbs., $\$ 5.00$. By parcel post: 1 lb., 85c; 5 lbs., \$3.15; J 0 lbs., $\$ 5.20$.

DRY OR POWDERED LIME SULPHUR-This new preparation is taking the place of the liquid formula. Besides, it doesn't spoil. You can use as you want same, and then you also don't have to pay freight on water. Fourteen pounds Powdered Lime Sulphur will make 50 gallons of spray material. Full directions come with every package. Price, 1-lb. pkg., 35c; 5-lb., pkg., $\$ 1.50 ; 10-1 b . \$ 2.50 ; 25-1 b ., \$ 4.50$. By parcel post, 1-lb. pkg., 50c; 5-lb. pkg., $\$ 1.75$.

SULPHO TOBACCO SOAP-Kills all insects on plants; simple and effective. By freight: 3-oz. cake, 15c; 8-oz., 35c. Parcel post: 3-oz. cake, 20c; 8-oz. 40c.

TOBACCO DUST-For lice and other insects on all vegetable and flower plants. 1 lb., $25 \mathrm{c}$; 5 lbs., $\$ 1.00 ; 25$ lbs., $\$ 2.00$. Post paid, 1 lb., 35c; 5 lbs., $\$ 1.15$.

BLACK LEAF 40-A nicotine solution for destroying aphis, lice, etc., on both garden and flowering plants. A teaspoonful makes 1 quart of solution. This is one of the most effective preparations for general suckling insect. Oz.bottles, 30c; 1/4-1b. tin, $\$ 1.25$. Not mailable.

BUG DEATH-Very safe, being non-poisonous; effective on all garden insects. Price, by freight: Lb., 20c; 3 lbs., 45c; 5 lbs., 65c; 121/2 lbs., \$1.35; 100 lbs., $\$ 8.50$. Parcel post: Lb., 30c; 3 lbs., $60 \mathrm{c} ; 5$ lbs., $85 \mathrm{c} ; 121 / 2$ lbs., $\$ 1.90$.

SLUG SHOT, HAMMOND'S-Non-poisonous; a splendid powder for general use. $1 \mathrm{lb} ., 20 \mathrm{c} ; 5$ lbs., 65c; 10 lbs., $\$ 1.25 ; 25$ lbs., $\$ 2.50 ; 100$ lbs., $\$ 9.00$. Post paid, 1 lb., 30c; 5 lbs., 80c; $10 \mathrm{lbs}$., $\$ 1.50$.

FISH OR WHALE OIL SOAP_-Prevents and cures aphis and other troubles on plants and trees. No. 4-1 lb., 35c; 5 lbs., $\$ 1.50$. By parcel post: 1 lb., 40c; 5 lbs., $\$ 1.7 .0$.

CUT WORM KILLER-Simple, easy to use; a sure dose for eradication of all cutworms. $1 \mathrm{lb}$., 30 c; 5 lbs., \$1.25, not mailable.

MELROSINE-The only remedy. Endorsed by leading authorities. The general contact insecticide that kills rosebugs and other insects. Used with any good spray pump, diluted with from 20 to 25 parts of water. Pleasant and harmless to use. Guaranteed effective when used according to directions on can. Pt., $\$ 1.00$; trial size, 50c, postage $10 \mathrm{c}$ extra. 


\section{Spray Pumps for Every Need MODOC BUCKIT PUMIP}

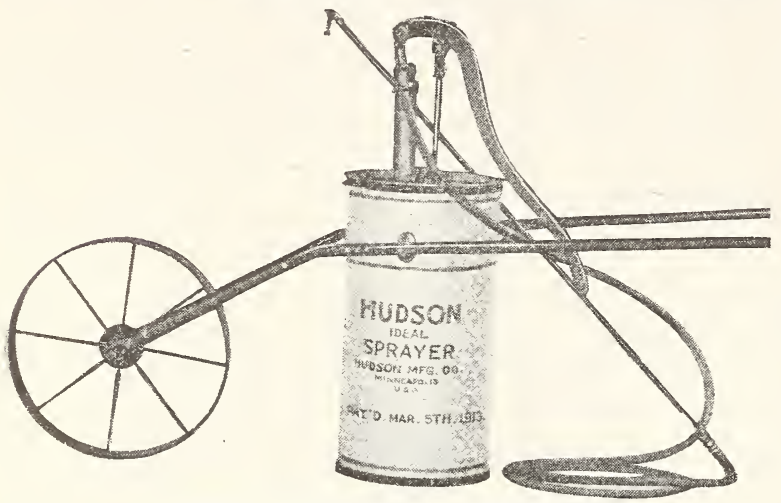

IDEAI PORTARIF SPRAYFR

Equipment: Tank 15 gallons, portable, attached to an iron wheelbarrow frame with wheel; 10 feet $3 / 8$-in. pressure hose 10 feet 2-piece pipe extension; $1 \mathrm{~T}$ shut-off cock; 1 Brandt nozzle. Weight. 65 pounds. Price, $\$ 25.00$, f. 0. b. Vicksburg.

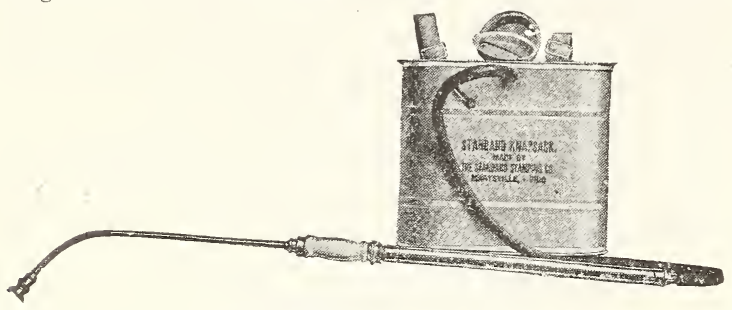

STANDARD SPRAYER

A pump gun style sprayer, made entirely of brass, with different nozzles; you can spray large or small orchards, potatoes or garden crops and poultry houses, and will also spray whitewash satisfactory. Price, Sprayer, $\$ 6.00$; postpaid, \$6.25. Price, Sprayer with Knapsack Tank, \$9.50; postpaid, $\$ 10.00$.

\section{MYERS' NO. 324 BUCKFT PUMP}

Furnished with lever handle, which gives additional force to the stream. This is a perfect double-acting pump, easy to operate. Complete with hose and graduating vermorel nozzle. Price $\$ 6.50$. Post paid \$7.00. Eight-foot extension pipe, $\$ 1.00$ extra, f. o. b., Vicksburg.

\section{IMAGIC BUCKET PUINP}

The only bucket pump in which both intake and outlet valves are mounted in one cage and easily removable. Makes a very easy operating pump. The large air chamber enables the operator to main tain a high pressure and a steady discharge. Price $\$ 5.00$; postpaid $\$ 5.25$.

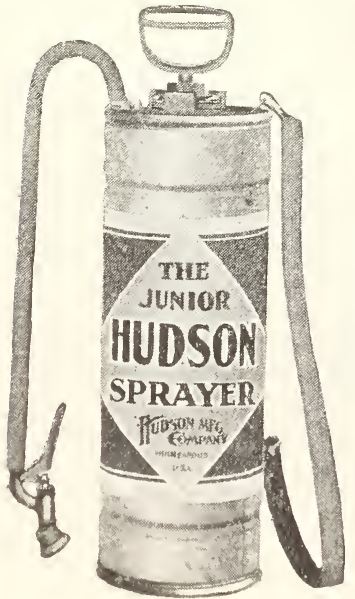

HUDSON JUNIOR

The Hundson Junior Sprayer is made for the man who needs a high pressure compressed air sprayer smaller than the Perfection 110. It will do any work the larger models can, for it differs from them only in capacity. Tank is galvanized and holds about $21 / 2$ gallons. Price $\begin{aligned} & \text { h5.00; } \\ & \text { postpaid, }\end{aligned}$ $\$ 5.25$.

This pump is used for a bucket spray and force pump, as well as for whitewashing. It will throw a stream 35 feet high. All solid brass, double action, bronze ball valve. Will whitewash and spray with same nozzle by simply turning the disc. Equipped with 5-ply pressure hose. Price, $\$ 5.00$. postpaid, $\$ 5.25$.

\section{IFINY DUST GUN}

The most practical dry powder sprayer on the mar. ket today. Each, $\$ 1.25$; postpaid, $\$ 1.40$.
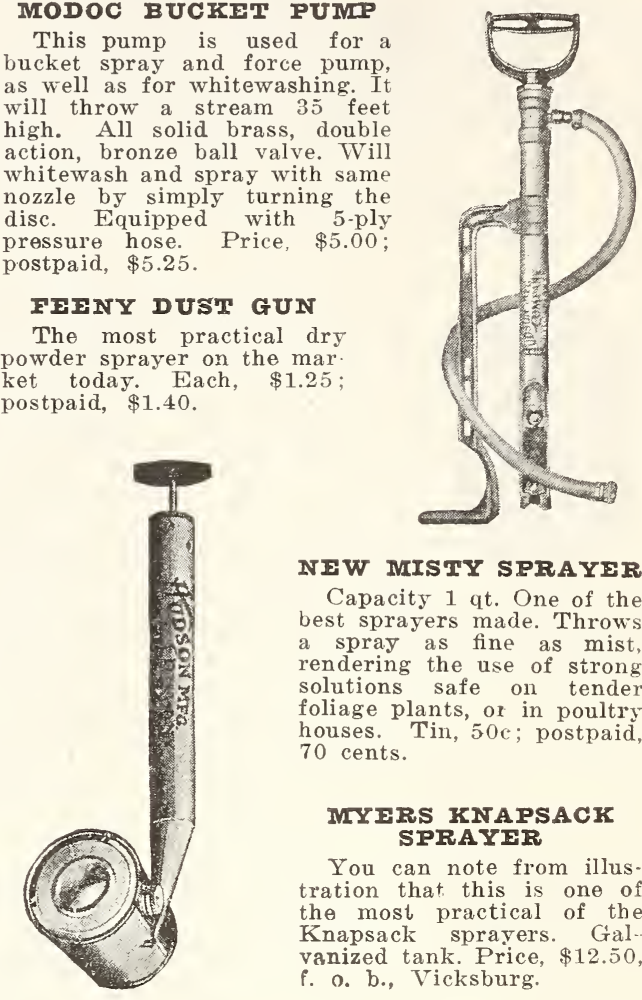

NEW MISTY SPRAYER

Capacity 1 qt. One of the best sprayers made. Throws a spray as fine as mist, rendering the use of strong solutions safe on tender foliage plants, or in poultry houses. Tin, 50c; postpaid, 70 cents.

\section{MYZRS KNAPSACK} SPRATIR

You can note from illus tration that this is one of the most practical of the Knapsack spravers, Gal vanized tank. Price, $\$ 12.50$, f. o. b., Vicksburg.

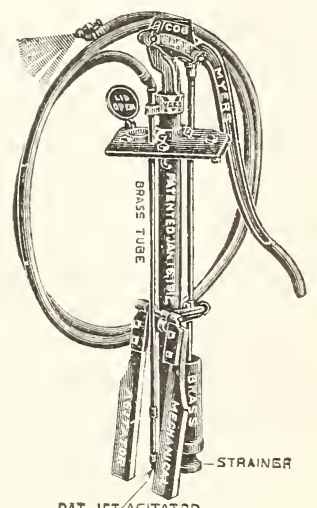

PAT JET AEITATOR

MYYER NO, 318 BAR REI PUIMP

Has malleable iron base. fits any regular size barrel. Cylinder valves and valve seats all brass; has $15 \mathrm{ft}$ of $1 / 2$-inch 5 -ply discharge hose; mechanical agitator and Vermorel nozzle. Price complete, excepting barrel, $\$ 15.00$; with barrel, com plete, $\$ 25.00$, f. o. b. Vicks burg.

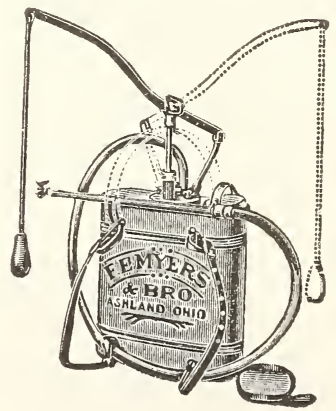

\section{HUDSON PERFECTION} SPRAYER

Same sprayer as the Hudson Junior only larger. same holding four gallons of liquid. No, $110 \mathrm{G}$, vanized tank, $\$ 6.50$; post paid $\$ 7.00 .960 ;$ paid, $\$ 7.00$. No. $110 \mathrm{~B}$ brass tank, $\$ 9.50$; postpaid $\$ 10.00$. 


\section{Seed Sowers, Garden Plows, Hanging Baskets}

For those who desire to do their gardening and farming in the modern and most economical way, we suggest that they avail themselves of some the latest approved equipment that we are offering at such reasonable prices. The farme' or gardener today who does not advance with the times will experience the misfortune of ha ring his profits cut by continuing to use the oldfashioned and out-of-date machinery.

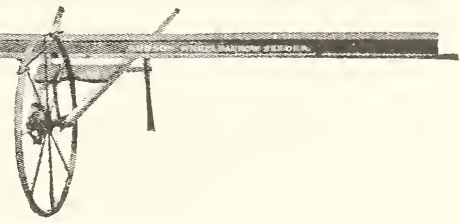

\section{THOMPSON'S WHEELBARROW SEED SOWER}

The Thompson Wheelbarrow Seeder gives a perfect uniformity and evenness of putting down the seed, more so than any other style we know of. We handle only the No. 2 Seeder, which is superior to the No. 1, from the fact that it sows in addition to the heavier seeds, like Timothy, Alfalfa and Clover Seeds, all Grass seeds and Lespedeza. Price: No. 2, 14-ft. Thompson Wheelbarrow Seeder, each, $\$ 12.50$, F. O. B. Vicksburg.

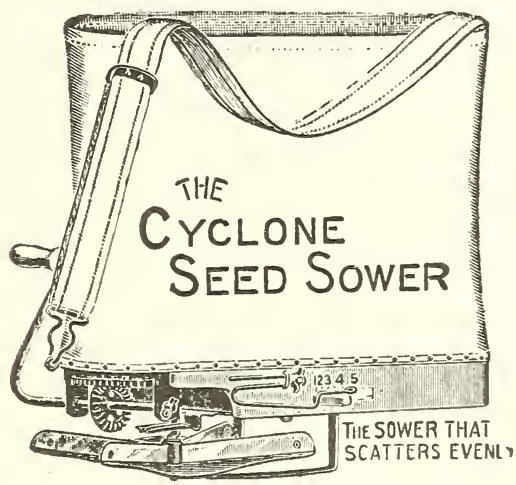

CYCLONE SEED SOWER

Will sow timothy, clover, oats, rye, wheat, millet, grass seeds, peas, sorghum, etc. Distributes evenly, works perfectly; has an agitator feed plate, which insures a uniform flow of seed. Price, each, $\$ 2.25$; postpaid, $\$ 2.40$.

\section{GREEN SHEET MOSS}

For wire flower baskets. Lb., 60c; by parcel post, $70 \mathrm{c}$.

\section{WIRE FLOWER POT BRACKETS}

Very neat and attractive in appearance. Made of steel wire and tinned after being made. Very strong. Easily put up and instantly removed; 6 inches in diameter. Each, 25c; doz., \$2.50. Postpaid, each 30c.

\section{SEGEMENT HAND CORN PLANTER}

This is the best one-hand corn planter on the market and very satisfactory. $\$ 2.00$ each. Postpaid, each $\$ 2.25$.

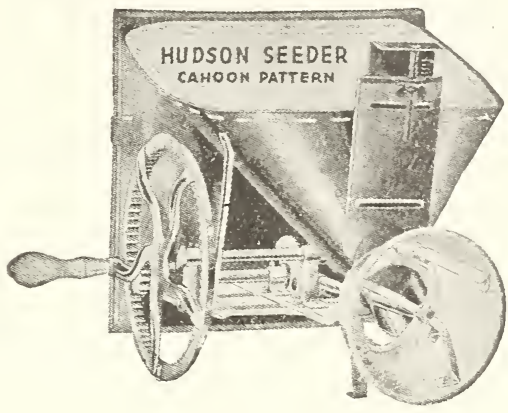

\section{CAHOON BROADCAST SEEDER}

One of the best seeders manufactured, and sows all kinds of grain, clover seeds, etc., rapidly and evenly. Price, each, $\$ 4.50$; postpaid. $\$ 4.75$.

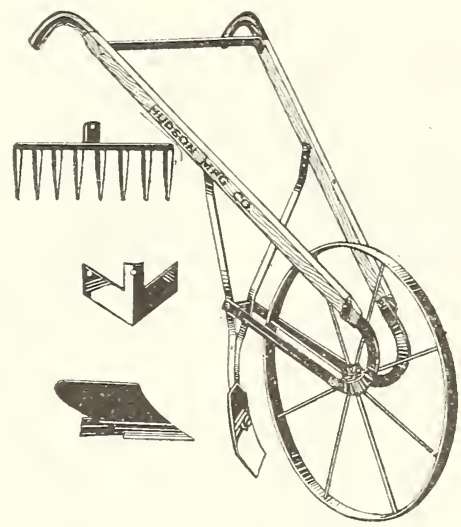

\section{HAND GARDEN PLOWS}

The most inexperienced and ignorant laborer on earth can handle this tool with entire success. All kinds of work can be done with this plow and combination of tools; plowing and breaking of the ground in spring and harrowing; cultivating. Price, each $\$ 3.75$, f. o. b., Vicksburg.

\section{SATO FLOWER AND PLANT BOX}

\section{All Year Round}

Self-watering and self-irrigating. For winter and summer use. Fill with water only once a week. Cannot overwater plants. Air goes direct to the roots. Prices, f. o. b., Vicksburg:

Model Price A- 8 in. high, $91 / 2$ in. wide, 23 in. long $\$ 3.50$

$\mathrm{B}-8 \mathrm{in}$. high, $9 \frac{1}{2}$ in. wide, $29 \mathrm{in.}$ long 4.00

C- 8 in. high, $9 \frac{1}{2}$ in. wide, 35 in. long 4.50

D- 8 in. high, $9 \frac{1}{2}$ in. wide, 41 in. long 5.00

WIRE HANGING BASKETS

8-inch, each......\$0.25 12-inch, each .......\$0.40

10-inch, each....... .35 Postpaid, 20 each extra 


\section{Canary Birds, Cages, Gold Fish and Supplies}

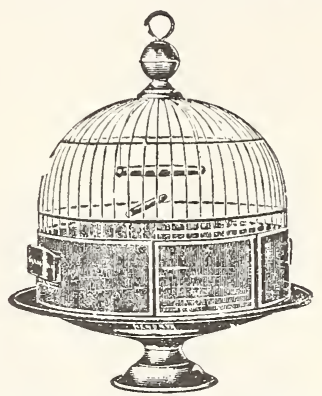

FANCY RRASS CAGES

These are all handsome fancy style, every one an ornament.

No. 8000 Brass Bungalow Square Cage, each___ $\$ 14.00$

No, 8020 Brass Bungalow Square Cage, each- 14.00

No. 274 Brass Round Cage, each

No. 275 Brass Round Cage, each _..._._. 6.50

No. 276 Brass Round Cage, each -

If wanted by parcel post, add $35 \mathrm{c}$ each for packing and postage.

\section{OBLONG BRASS CANARY CAGES}

No. 5004 Brass Cage, 95/8 x61/2-in., each _-____ $\$ 3.70$

No. 5006 Brass Cage, $10 \% 3 \times 71 / 8$-in., each _._._- 4.45

No. 5008 Brass Cage, $10^{3 / 4} \times 73$-in., each _._._. 5.30
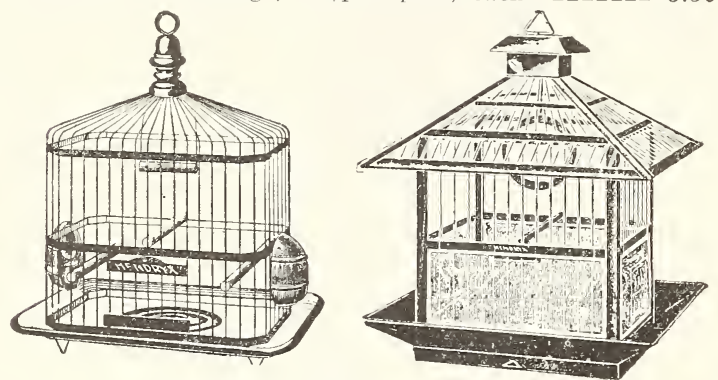

JAPANNRD CANARY BIRD CAGES

No. $165 \quad$ New Style Japanned Cage, 91/2 $\times 61 / 2$
inches, each -

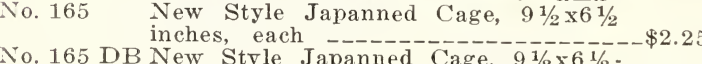

No. 165 DB New Style Japanned Cage, $91 / 2 \times 6 \frac{1}{2}{ }^{-}$
inches, each

No. 166 New Style Japanned Cage, 10x7.

No. 166 DB New Style Japanned Cage, $10 \times 7$. inches, each Style Japanned Cage, $11 \times 7 \frac{1}{1 / 2}$

No. 167 DB New Style Japanned Cage, $11 \times 7 \frac{1}{2}$
inches, each

No. 167 New Style Japanned Cage, $12 \times 8$ -

New Style Japanned Cage, $18 \times 8$.

No. 168 New Style Japanned Cage, 18x8-

No. 168 DB New Style Japanned Cage, $12 \times 8$.

3.00 3.85 4.00

No. 6 - Round, 10 -in. diameter, $16 \frac{1}{1 / 2}$ in. high, $\$ 5.00$

No. $6 \frac{1 / 2}{-}$-Round, 11 in. diameter $\times 17 \frac{1}{2}$ in. high 5.50

No. 7 -Round, 12-in. diameter, 18 in. high, 6.00

If cages are wanted by parcel post, add $35 \mathrm{c}$ each for packing and postage.

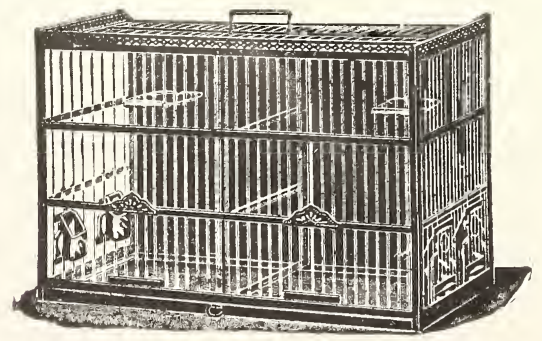

BREFDING CAGES

No. $86 \mathrm{~S}$-Metal Breeding Cage, $17 \times 8 \times 13$ ins._-_- $\$ 5.80$ No. 86 - Metal Breeding Cage, $20 \times 10 \times 14$ ins.-.- 7.40 No. 87 - Metal Breeding Cage, 22x11x15 ins...-- 8.10

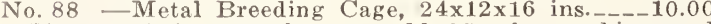

If wanted by parcel post, add $35 \mathrm{c}$ for packing and postage.
Our birds are the genuine Hartz Mountain strain. Each one is thoroughly tested before shipping to be sure it is a No. 1 guaranteed singer. Price $\$ 10.00$ each. St. Andreasburg Rollers, highly trained. Price $\$ 10.00$ each.

Female canaries for breeding, $\$ 2.50$ each, f. o. b., Vicksburg.

\section{MISCEIIANFOUS BIRD SUPPLIRS}

Bird Cage Seed Cups, opal or glass, 20c; postpaid $\$ .25$ Bird Cage Bath Cups _-_._._-each 20c; postpaid .30 Bird Cage Brackets, 12-in.--_-each 35c: postpaid .45 Bird Cage Brass Springs_--_each 20c; postpaid .25 Bird Cage Chain with springs, each $30 \mathrm{c}$; postpaid .35 Bird Cage Neses, wire _-_.--_each $10 \mathrm{c}$; postpaid .15

\section{BIRD FOODS, FTC.}

Phil. Bird Manna each 15e; postpaid $\$ .20$ Phil. Mixed Canary Seed__-_pt. box $20 \mathrm{c}$; postpaid .30

Phil. Silver Gravel _-_-_-_-_pt. box $15 \mathrm{c}$; postpaid .25

Phil. Red Gravêl _...- box $15 \mathrm{c}$; postpaid .25

Phil. Bird Bitters -

Phil. Bird Mite Exterminator_-- box 25c; postpaid .30

Phil. Bird Moulting Pepper---_ox 250; postpaid

Phil. Bird Nestling Hair _-_--box 10c; postpaid .15

Canary Seed, plain

Canary Seed, mixed

Hemp Seed - - - -

Rape Seed

Sunflower Seed -

Cuttle Fish Bone - -

Cuttle Fish Bone, with holder_-each $15 \mathrm{c}$; postpaid .20

\section{GOID FISH}

American Gold Fish-The well known bright scarlet and gold color. Small, each 15e; medium, each $25 \mathrm{c}$ large, each, $50 \mathrm{c}$; Tin bucket for shipping, extra, $35 \mathrm{c}$ each.

\section{GOID FISH BOWIS}

Glass Bowls-Made of clear glass, in following sizes: 2-quart, each 4-quart, each 2 -gallon, each - 1.25

3 -gallon, each -

These cannot be sent by parcel post, they must go by freight or express, at buyer's expense.

FISF FOOD

Wafer Fish Food, pkg., postpaid

\section{AQUARIUIM CASTIES}

Assorted styles, priced from $35 \mathrm{c}$ to $75 \mathrm{c}$ each.

BFNNETT'S MIIK BONE DOG BISCUIT

A superior preparation. Keeps dogs in good condi. tion. Ask for circulars. Per box $40 \mathrm{c}$; postpaid, $50 \mathrm{c}$.

BENNETT'S MITK BONE PUPPY BISCUIT

Especially prepared for puppies. They thrive and grow fat on M. B. Biscuits. Per box $40 \mathrm{c}$; postpaid $50 \mathrm{c}$.

\section{SAVES MONFY BY SAVING CROPS}

It is estimated that rats and mice consume grain each year in the United States alone to the value of more than $\$ 10,000,000$. Most of this waste can be saved if RAX is given a chance.

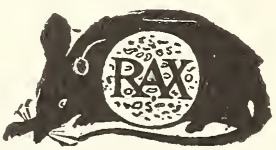

RAX IS NOT A POISON

While it is absolutely deadly to rats and mice, it is harmless to human beings, domestic animals, poultrs and birds. It may be used anywhere with complete safety.

RATS LEAVE BEFORE THEY DIE

Within a few days after eating bait prepared with Rax, rats and mice become feverish and seek the open air where they die-outdoors.

\section{HOW TO USE RAX}

Add water to the bottle and shake contents until water is cloudy. Then moisten bait (bread, crackers or cheese) with the mixture and place it near the holes. Rax does not affect the taste of the bait.

Directions are furnished with each package. One bottle is enough for an ordinary house; allow one bottle to each 500 feet of floor space in large barns, mills, ets. Price, $75 \mathrm{c}$ per bottle, postpaid. 


\section{Lewis Bee Hives and Supplies}

We are selling agents for the Famous Lewis Beeware and can assure of prompt shipment and goods of quality. Prices quoted below are F. O. B. Memphis, Temn., Warehouse and not Vicksburg. Prices F. O. B. Vicksburg higher. Complete Beeware Catalog on request

\section{SECTION BOXES}

TVe carry the following sizes in stock, all No, 1 grade $-41 / 2 \times 17 / 8$, 2-Beeway; $41 / 4 \times 1 \frac{1}{2}$, plain; $4 \times 5 \times 1 \frac{3}{8}$, plain $35 / 8 \times 5 \times 1 \frac{1}{2}$. plain. Prices as follows:

Beeway Sections, $100, \$ 1.60 ; 250, \$ 3.75 ; 500, \$ 7.25$; 1000 for $\$ 14.50$.

Plain sections, 100 for $\$ 1.50 ; 250, \$ 3.50 ; 500, \$ 6.75$ 1,000 for $\$ 13.50$. By parcel post, add 25c per 100 for postage.

\section{BEE GLOVES}

Bee Gloves, canvas, large, medium or small, per pair. $95 \mathrm{c}$. By parcel post, $\$ 1.05$

HOFFMAN SELF-SPACING FRAMES

Prices in Flat, including nails, 10 frames, $80 \mathrm{c} ; 100$ frames, $\$ 7.00$.

\section{SHALLOW EXTRACTING FRAMES}

Prices, in Flat, including nails, 10 frames, 60c; 100 frames, $\$ 5.25$.

PRICE LIST OF COMIB FOUNDATION
In lots of-
Medium Brood $1 \mathrm{~b}$
Light Brood

BEE SMOKERS

Bingham Smokers

Name Size of barrel Each By mail Big Smoke, tin, shield__-_-_-_-4 x10 \$2.25 $\$ 2.40$ Big Smoke, tin, no shield ------4 x10 $\quad 1.75 \quad 1.95$ Smoke Engine, tin _-_-_-_-_-4 4 × $7 \quad 1.50 \quad 1.67$ Doctor $-31 \%$ x $7 \begin{array}{lll}1.25 & 1.36\end{array}$ Little Wonder Smoke Engine, copper Doctor, copper

\section{QUEEN EXCLUDING HONEY BOARDS} WOOD BOUND ZINC BOARD

Prices as follows:

One Ten Hive

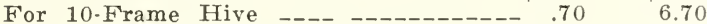

$$
\text { UNBOLND ZINC BOARD }
$$

Prices as follows: 8. Frame, $12 \times 191 / 8$ 10-Frame, $16 \times 20$

\section{One}

\section{BEE VEILS}

Excelsior Veil, each

Cotton, with Silk Face, each

All Cotton, each

By mail, 5 c extra.

\section{ONE-STORY HIVES}

Not including Foundation Starter

In Flat, including nails. 1 Hive 5 Hives 1-Story, 8-Frame -

\section{DOVETAILED COMB HONEY SUPERS}

The following prices are in flat, without sections or starter.

No. 1 , or Regular, taking $4 \frac{1}{2} \times 1 \frac{7}{8}$ ins. Beeway Sections

1 Super 5 Supers

8.Frame -

10-Frame -

No. 2, or Plain, taking $1 \frac{1 / 4 \times 1 / 2}{1}$ ins. Sections. 1 Super 5 Supers $\begin{array}{rr}\text { 8- Frame } & \\ 10-\text { Frame } & \end{array}$

No. $4,4 \times 5 \cdot$ in., taking $4 \times 5 \times 13 / 8-i n$ Plain Sections 1 Super 5 Supers

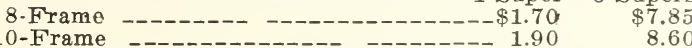

10-Frame Woven Wire Style

Price, each State if wanted for 8 or 10 -Frame Hives.

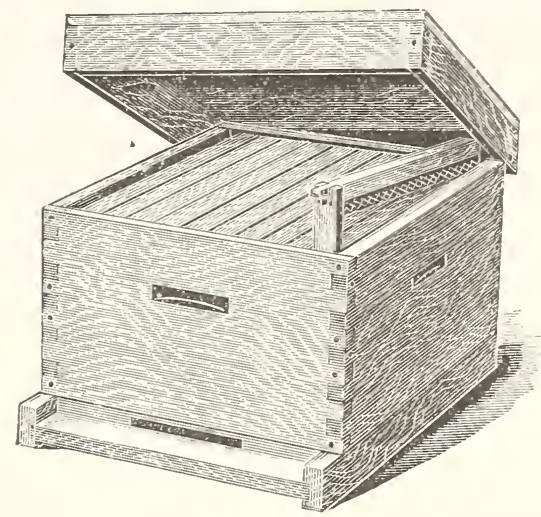

SHALLOW EXTRACTING SUPER, 5 11-16 INCHES DEEP

In Flat, including nails.

8-Frame, size $5 \frac{5}{8}$-in. deep 1 Super 5 Sinper: $-\$ 1.20-\$ 4.90$

\section{EMPTY SUPERS}

Always state which style Super Shell is wanted. whether the No. 1, No. 2 and No. 4, or for Shällow Extracting Frames.

In Flat, including nails. 1 Super 5 Snpers 8-Frame Size, for Section Holders $--\$ .70 \quad \$ 2.80$ 10-Frame Size, for Section Holders --- $.75 \quad 2.90$ 8. Frame Size, for Shallow Ext. Frames 80 10-Frame Size, for Shallow Ext. Frames .85

\section{DOVETAILED BODIES}

When extra Bodies are wanted, the prices are as follows, including Brood Frames and Division Board and Metal Rabbets, except 10-Frame do not have Division Boards:

In Flat, including nails. 1 Body 5 Bodies 8-Frame _._. 10-Frame 8-Frame, without inside fixtures - - $1.20 \quad 4.60$ 10-Frame -

BOTTOMS FOR DOVETAILED HIVES

In Flat, including nails. 1 Bottom 5-Bottonis 8-Frame 10-Frame _-_-_-_ _-

\section{COVERS FOR HIVES}

In Flat, including nails 1 Cover 5 Covers 8-Frame, Excelsior _-_-_-_-_-__- \$.85 $\$ 3.95$ 10-Frame, Excelsior 8-Frame, Metal Roof, Inner Cover--- 1.50 10-Frame, Metal Roof, Inner Cover---- 1.60

\section{FENCE SEPARATORS}

Prices, any style, $10,90 \mathrm{c} ; 100, \$ 8.00$.

No. 2 or P Fence-Used in No. 2 or Plain Super, with Plain Section Holders and Plain $4 \frac{1}{2} \times 4 \frac{1}{2} \times 1 \frac{1}{1} 2 \mathrm{Sec}$

tions.
No. 4 or $4 \times 5$ Fence-Used in No. 4 Supers. with Plain Section Holders for $4 \times 5 \times 1 \frac{3}{8}$ Sections.

\section{WOOD SEPARATORS}

Slotted Wood Separators - - - - - - 10, 30c: 100, \$3.00

\section{SECTION HOLDERS}

Slotted Section Holders, per $100 \ldots \ldots \ldots+\ldots$
Plain Section Holders, per 100

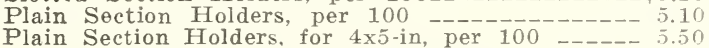
PRICE LIST OF TINNED WIRE

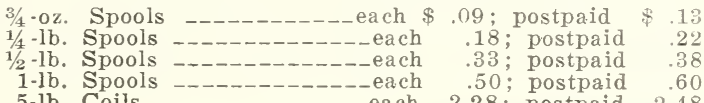




\section{POULTRY SUPPLIES}
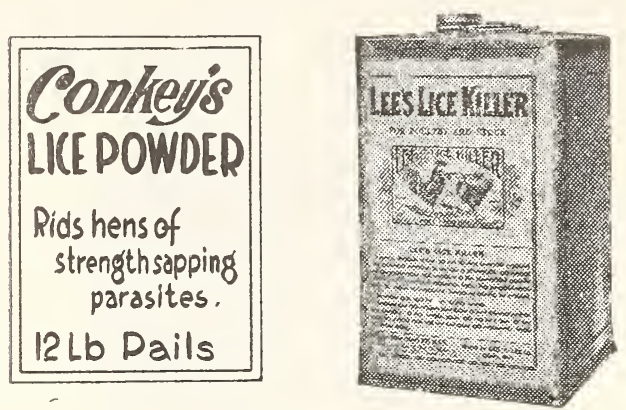

\section{CONKEY'S POULTRY REMEDIES}

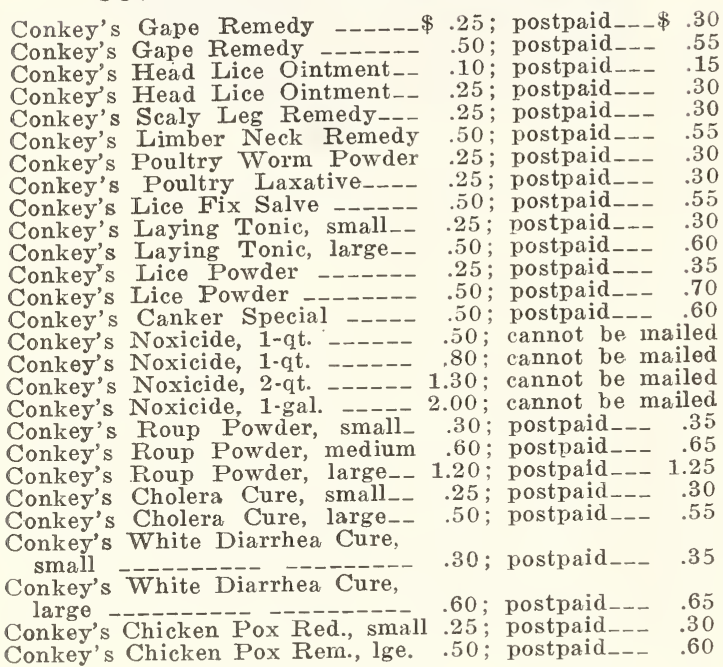

\section{DON SUNG}

Don-Sung (Chinese for egg laying) is given in the feed and doesn't force or burst the hen in any way, in fact, it makes her healthier. It is a new scientific discovery for hens, that merely stimulates the egg organs, making them strong and vigorous and as a result they making them strong and vigorous and as a result they it. Ask for circulars. Price per box, 50c; large size, $\$ 1.00$; postage $5 \mathrm{c}$ extra.

\section{AVICOL}

A safe and effective remedy in tablet form for White Diarrhea, Cholera, etc., in small and large grown fowls. Avicol is now being used by thousands of successful poultry raisers the world over. Write for circulars. Price 25c, 50c and $\$ 1.00$ per pkg. Postage 5c extra.

\section{TALCIMIZED SODIUM FLOURIDE Kills Poultry Lice}

Talcimized Sodium Flouride is made especially for poultry and carries the Government's directions for applying. It is safe, easy to use, inexpensive and absolutely does the work quickly and effectively. Price, 35 (enough to treat 50 chickens). Postpaid, $40 \mathrm{c}$.

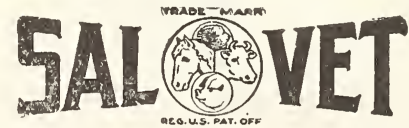

Sal Vet-Destroys worms in Hogs, Sheep, Horses and Cattle. Simply put Sal Vet in the animals' troughs, or give it to them in their feed. Send for circulars. 5.1b. package

15-lb. package

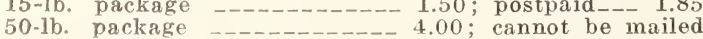

$100.1 \mathrm{~b}$. package

\section{PIPENE}

One application cures the worst case of Roup. Pipene is injected in the nostrils from inside the mouth and one treatment effects a sure cure. Price, 60c; parcel post, $65 \mathrm{c}$

\section{DIARRENE}

Prevents and cures White Diarrhoea in baby chicks; is absolutely a sure and safe remedy. Price, 60c; by parcel post, $65 \mathrm{c}$.

\section{COLDENE}

For colds in chicjrens; put up in tablet form, abso. lutely guaranteed. Price, 60c a box. By parcel post, 65 cents.

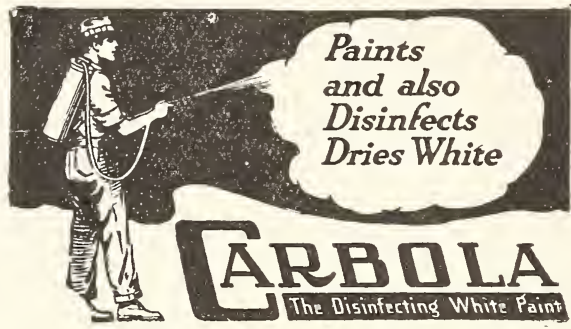

\section{CARBOLA}

The disinfectant that paints. Carbola is infinitely superior. to lime, which loses what slight disinfeetant qualities it ever had by slacking when exposed to the air. It may be used on either stone, brick, wood, metal or cement, and can be put on over a whitewashed or painted surface. Can be applied with either sprayer or brush. Price, 5-lb. package, 75c; postpaid, 90c; 10-lb. pkg., $\$ 1.25$; postpaid $\$ 1.50$; postpaid not past 3 rd zone.

\section{ZENOLEUM}

A scientific compounded preparation. The various kinds are used for live stock and poultry to prevent lice and mites as well as general use about the farm, bar'n and the house. Zenoleum is used and recommended by fifty agricultural colleges and experiment stations. Zenoleum Dip and Disinfectant, 8-oz. can, 35c; 1 qt., $75 \mathrm{c} ; 2$ qts., $\$ 1.25 ; 1$ gal., $\$ 2.00$. Cannot be mailed.

\section{COW EASE}

Cow Ease keeps off flies; gives cows a chance to feed in peace; repellant to lice; good for barn or cattle itch; does not gum the hair; increases the flow of milk; good for spraying hogs-in fact, Cow Ease is one of the best preparations of its kind on the market. Qt., 50c; 1/2 gal., $75 \mathrm{c}$; gal., $\$ 1.25$.

\section{LEE'S POULTRY REMEDIES}

Not past 3 rd zone Lee's Egg Maker, 2-lb. box_---\$.40; postpaid_-- $\$ .50$ Lee's Egg Maker, 5-1b. box_-- .90; postpaid_-- 1.00 Lee's Lice Powder, small size_- .25; postpaid_-- .35 Lee's Lice Powder, large size-- .50 ; postpaid_-- .60 Lee's Liquid Lice Killer, 1-qt. . .60; cannot be mailed Lee's Liquid Lice Killer, 2-qt.- .90; cannot be mailed Lee's Liquid Lice Killer, 1-gal. 1.50; cannot be mailed Lee's Egg-O-Hatch _._____ . .50; postpaid___ .55

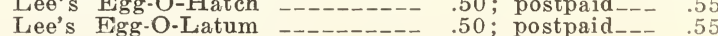

\section{LEE'S GERMOZONE}

Liquid, 4-oz. bottle, 40c; 12-oz. bottle, $75 \mathrm{c}$; not mailable Tablets, small size, 65c; large size, $\$ 1.25$ per box. Post paid, $70 \mathrm{c}$ and $\$ 1.30$.

\section{LICENE}

Licene will destroy every louse and "nit" on your chickens, usually keeping them free from lice for six months. Per tube, 60c: by parcel post, 5 c extra. 


\section{ANDERSON HATCH-AN-EGG BOXES}

This is the best shipping box on the market today for transporting value eggs for hatching. Express Parcel Post

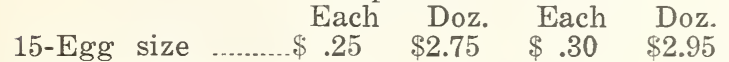

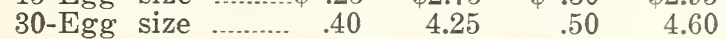

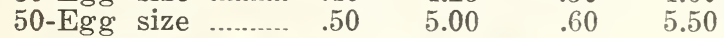
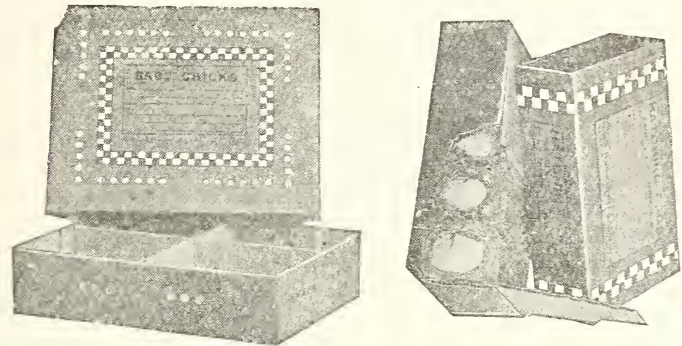

LIVE CHICK SHIPPING BOX

Made especially for shipping day-old chicks. Folded flat for shipping, but easily set up and made ready for use.

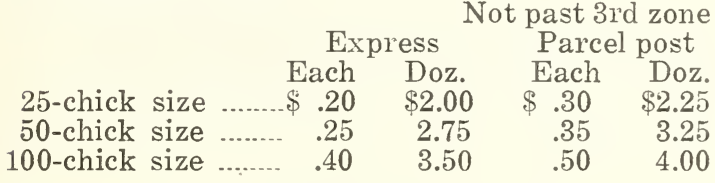

\section{EYRIE SHIPPING COOPS}

Light in weight, but strong and durable. Ends and sides heavy corrugated cardboard. Top and bottom wood.

No. B, 21x12x22 inches deep, each $\$ .90$ No. C, $21 \times 18 \times 22$ inches deep, each No. D, 21x24x22 inches deep, each

1.10

Prices f. o. b. Vicksburg.

\section{WIRE HEN'S NEST}

These nests are intended to be fastened with screws or screw hooks-if wanted removable. They afford no place for vermin and allow the air to circulate freely, advantages not obtained when wooden boxes are used. They are intended to be filled with straw, which can be readily removed. Each, 25c; doz., $\$ 2.80$. Postpaid, each, 40c; 12 for $\$ 3.10$, not past 3rd zone.

\section{HUMPTY DUMPTY EGG CARRIER}

One of the handiest egg carriers on the market. This carrier will hold 12 doz. eggs. Can be folded flat for shipment and is made of strong but light wooden slats $f$ a s t e n ed with strong steel wires. Very handy and something every poultryman should have. 3-doz. size 60c; postpaid, 75c. 6-doz. size 70c; postpaid, 85c. 9-doz. size, 80c; postpaid, $\$ 1.00$. 12-doz. size, 90 c; postpaid, $\$ 1.10$.

\section{THE “BABIE” CHICK FEEDER}

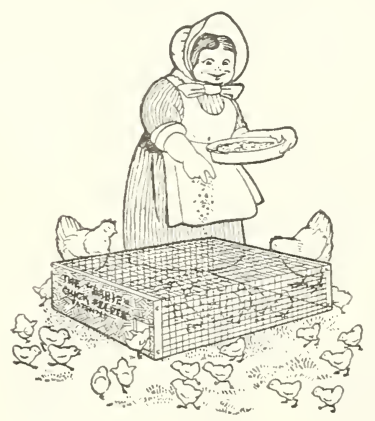

This simple wire feeder protects the little chicks and insures them plenty of feed, and will pay for itself many times over in economy of feed. It can be used to prevent mother hens from straying with their broods, and also in connection with the Lawn Park Brood Coops. Price, $\$ 1.50$; postpaid, $\$ 1.70$.

\section{TUCK END BUTTER CARTONS}

(Not corrugated). For 1-lb. Square Prints. For butter, our Tuck End Butter Cartons (to be used in combination with Corrugated Boxes, for parcel post shipping) furnish a sanitary and convenient method of packing. These cartons are made of the finest grade of manila paper, paraffined both sides. 100 for 90c. Postpaid, 100 for $\$ 1.00$.

\section{THE LAWN PARK COOP}

Gives the chicks sunshine, fresh air, grass and pro-
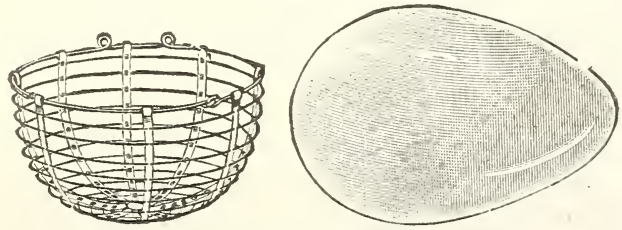

NEST EGGS

Knox Lice Medicate Nest Eggs-These eggs are a perfect imitation of the hen's egg, containing a powerful disinfectant, which keeps all lice, mites, etc., out of the nest and off the hen. Each 8c; doz., 75c. Postpaid, each $15 \mathrm{c}$; doz., 90c.

Lime Nest Eggs-Non-breakable, Antiseptic. A perfect shape, making it a splendid and lasting accessory. Doz., 40c. Postpaid, doz., 50c.

Porcelain-These are made of first class glass. They will not break easily and will last a lifetime. Doz., 40c. Postpaid, doz., 55 cents. tection from all enemies. This coop is made to telescope, therefore affords chicks roving space, yet they are safe. Has removable bottom, makes cleaning easy; sanitary; keeps out lice and mites, and gives ample ventilation. Size coop, closed 18x24 inches. When open with park extended, $18 \times 48$ inches. Price, each $\$ 4.00$, f. o. b., Vicksburg.

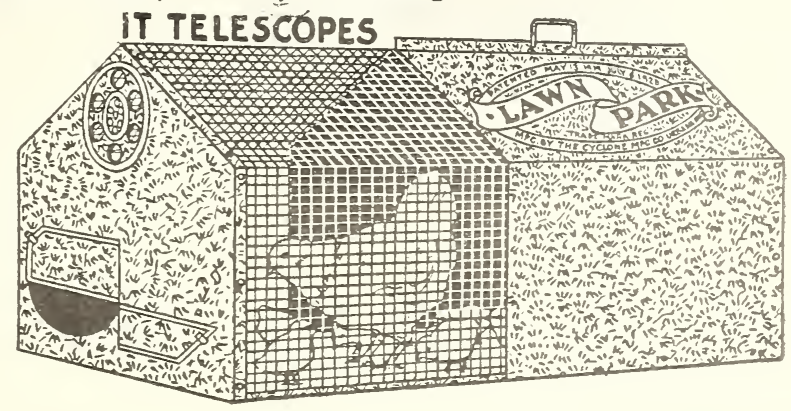




\section{Poultry Feeders and Founts}
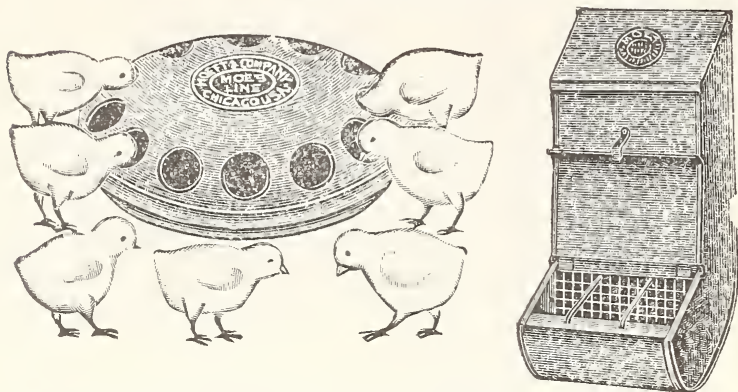

MOE'S ROUND BABY CHICK FEEDER

The most convenient feeder on the market. Can also be used for water. Two sizes. No. 11, 6 inches with 6 holes, and No. 12, 81/4 inches with 12 holes. Price: No. $11,20 \mathrm{c}$, by express; $30 \mathrm{c}$, by parcel post. No. 12 $30 \mathrm{c}$, by express; $40 \mathrm{c}$ by parcel post.

\section{MOE'S DRY MASH HOPPERS}

A strictly high ruality hopper, properly designed. The curved bottom keeps the feed in easy reach and the taper shape of the hopper prevents the feed from clogging. Height 19 inches. No. 35, width 81/2 inches, each $\$ 1.50$; postpaid, $\$ 1.75$, No. 36 , width 12 inches. each $\$ 2.00$; postpaid, $\$ 2.35$. No. 13. width 18 inches. each $\$ 2.40$; postpaid $\$ 2.80$.
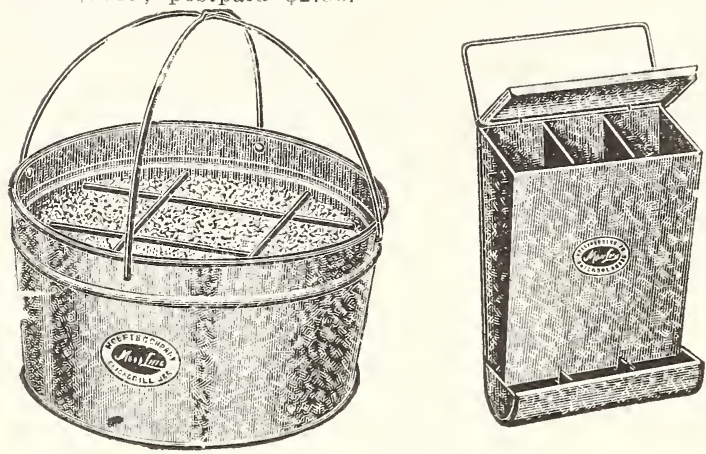

MOE'S ROUND MASH HOPPER

A good, economical Dry Mash Feeder, made of heavy galvanized iron with a capacity of 8 quarts. Can be gavanized iron with a capacity or 8 quarts. Can be try house and thus hung up out of the litter at any height desired. Has a rolled-in edge, and wire grid which rests on the feed and prevents the birds from wasting it. The top wire bales also prevent the chick ens from getting in the hopper. Price, each $75 \mathrm{c}$; postpaid $95 \mathrm{c}$.

\section{GRIT AND SHELL BOXES}

Grit, shell and charcoal have now become a recognized essential part of the diet, insuring healthy fowls. and it cannot be more economically supplied than in one of these triple compartment boxes.

No. 45,2 cempts., for chicks_._ $\$ .40$; postpaid $\$ .50$ No. 9,3 compts., for hens _... .90 ; postapid 1.10

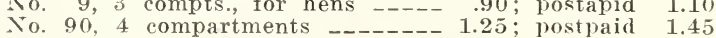

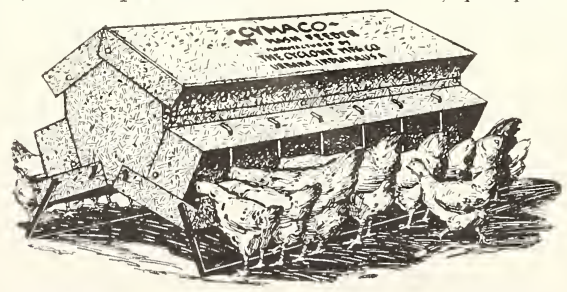

CYMACO DRY MASH FEEDER

This is a new Mash Feeder, and one with a number of special features, as follows: Stands on legs, can be placed in center of pen, feeds on both sides, flow adjust able, troughs shedded, equipped with agitators. Made in two sizes. No. 12, 12 inches long, $\$ 2.25$; No. 24, 24 inches long, $\$ 3.75$ each, f. o. b., Vicksburg.

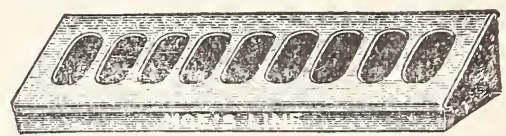

MOE'S SINGLE FEEDING TROUGH

For chicks and growing stock. Accurately st.amped with dies. No rough edges, and can be hung on the wall. Sliding top. No, 55, length 12 inches, each $35 \mathrm{c}$ No. 56, length 18 inches, each $40 \mathrm{c}$; No. 57, length 24 inches, each $55 \mathrm{c}$. Postpaid, add $10 \mathrm{c}$ each.

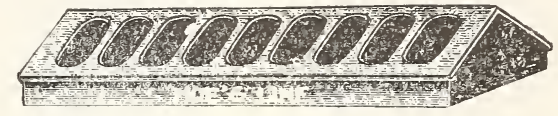

MOE'S DOUBLE FEEDING TROUGH

Double trough with sliding top, easily filled and cleaned. Accurately stamped with dies. No rough edges. No. 58, length 12 inches, each $45 \mathrm{c}$; No. 59, length 18 inches, each 60c; No. 60, length 24 inches, each $70 \mathrm{c}$. Postpaid, add $10 \mathrm{c}$ each.

\section{MOE'S TOP FILL FOUNTAIN}

Fills from the top. Dead air space keeps water cool in summer and from freezing in winter. Now made with square pan, which does away with spilling when hung up. Can be used for two pens at the same time. Manufactured in 3 sizes.

No. 1, 1-gallon capacity

No. 2, 2-gallon capacity

No. 4, 4-gallon capacity

Br parcel post, 25c each extra.
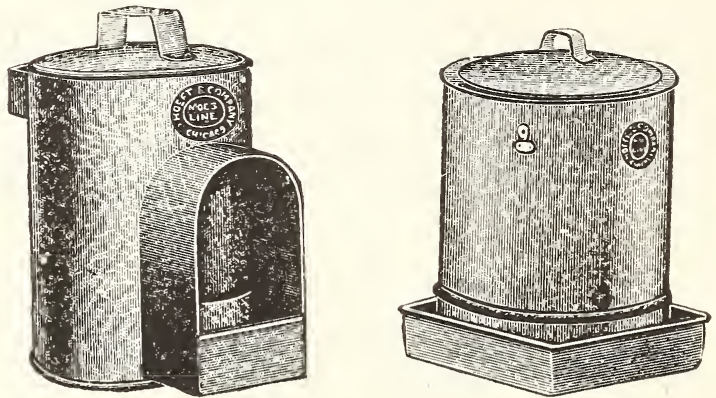

\section{WALL OR HUB FOUNTAIN}

The covered outlet keeps out dust and dirt, and a removable plate prevents any floating rubbish from being drawn into the reservoir.

No. 97, 2-qt. capacity_-__-_each $\$ .90$; postpaid $\$ 1.05$ No. 98, 1.gal. capacity _-_-each 1.10 ; postpaid 1.25 No. 99, 2-gal. capacity_____each 1.40 ; postpaid 1.60
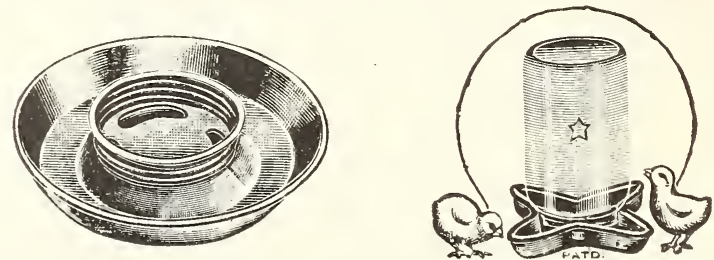

\section{ECONOMY FOUNT OR FEEDER}

No parts to come unsoldered. Leaking impossible. Will fit pint, quart or half-gallon Mason jar. Convenient, cheap and sanitary. One size only. Price of holder without jar: each, $30 \mathrm{c}$. By parcel post, each $40 \mathrm{c}$

STAR JAR FOUNTAIN AND FEEDER

No parts to come unsoldered. Leaking impossible. Will fit pint, quart or half-gallon Mason jar. Con venient, cheap and sanitary. One size only. No. 32 each 15c; 6 for $75 \mathrm{c}$. Postpaid, each 20c: 6 for $90 \mathrm{c}$. 


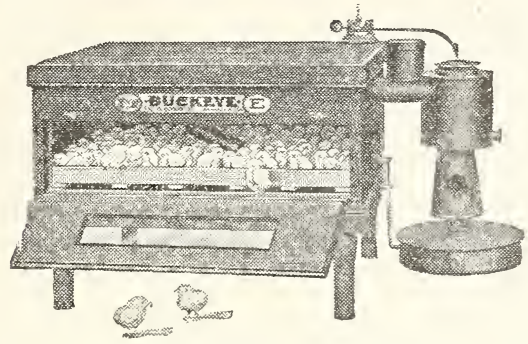

BUCKEYE INCUBATORS

Bucḱeye No. 14, Style E, 65-egg Incubator----- $\$ 16.50$ Buckeye No. 16, Style E, 110-egg Incubator--- 27.50 Buckeye No. 17, Etyle E, 210-egg Incubator ---36.75 Buckeye No. 1, Standard 110-egg Incubator--- 37.50 Buckeye No. 2, Standard 175-egg Incubator Buckeye No. 2, Standard 175-egg Incubator---- 44.50 Buckeye No. 4, Standard 350-egg Incubator_--- 68.00

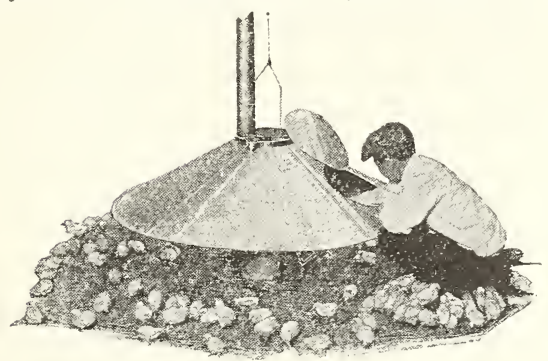

\section{BUCKEYE STANARD COLONY STOVE BROODER}

The most remarkable coal-burning brooder ever invented. It is self-feeding, self-regulating, simple, safe and everlasting. Cuts the cost of equipment and cost of operation to less than half. Reduces the time and labor to less than a fourth. Simple as a kitchen range. Broods from 100 to 1000 chicks. Write for special circulars. No. 18-Capacity 500 chicks, price_-_-_ No. 19 -Capacity 1000 chicks, price _-_._-_-_ 26.50

\section{BUCKEYE BLUE FLAME BROODER}

In the construction of this Brooder valves of every character have been eliminated. Experience proved them to be dangerous and impractical. The lighting process is exactly like lighting an ordinary house lamp. No priming needed and no special education required to operate it. Produces greater volume of heat with smaller consumption of oil. Will not use more than gallon of oil in 24 hours. Large channels guard against stopping oil supply and assure continuous heat. In three sizes:

No. 27-Capacity up to 200 chicks, diam. 34 in.-- $\$ 17.50$ No. 28-Capacity up to 350 chicks, diam. 42 in 20.00 No. 29 - Capacity up to 500 chicks, diam. 52 iu. -22.50
All above prices on incubators and brooders, F. O. B. Ticksburg.

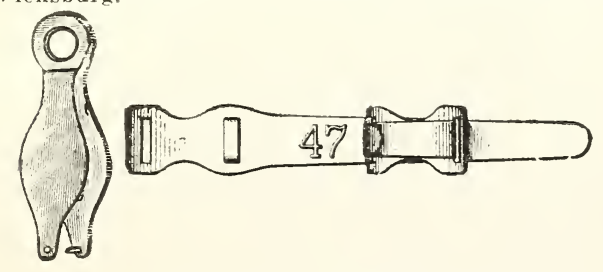

CHAMPION LEG BANDS

This aluminum band is made in one piece, adjustable to fit any fowl. Held by double lock; it is impossible for them to lose off. Numbered from 1 to 400 . Price, doz., $15 \mathrm{c} ; 25$ for $25 \mathrm{c} ; 100$ for $75 \mathrm{c}$, postpaid.

\section{COLORED SPIRAL LEG BANDS}

Made in many different colors-red, green, blue, yellow, pink, white, etc. Slip on just like a key ring; no tools required. Will not come off; fowls cannot lose or remove them. Made in all sizes. State for what breed you want the bands. 12 for $20 \mathrm{c}$; postpaid, $25 \mathrm{c} ; 25$ for $35 \mathrm{c}$; postpaid, $40 \mathrm{c}$ : 50 for $65 \mathrm{c}$; postpaid, $70 \mathrm{c} ; 100$ for $\$ 1.25 ;$ postpaid, $\$ 1.35$.

\section{POULTRY PUNCHES}

Pettey Poultry Punch-Cuts clean hole with ease. Price, 30c, postpaid.
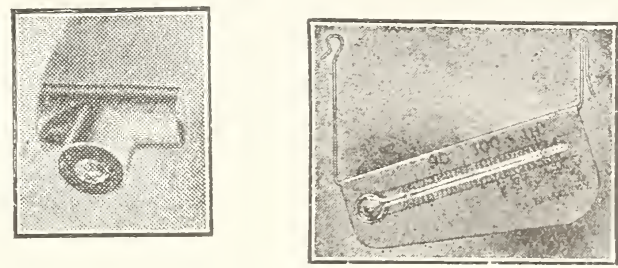

\section{X-RA Y EGG TESTER}

Designed for use on an ordinary hand lamp and fits over any style burner with a diameter approximately that of the tester. Each $30 \mathrm{c}$; postpaid, $40 \mathrm{c}$

\section{BUCKEYE INCUBATOR AND BROODER EXTRAS}

Buckeye Inc. Thermometers, each $\$ 1.00$; postpaid $\$ 1.10$ Buckeye Inc. Lamp Bowls, each_- 100 ; postpaid 1.15 Buckeye Inc. Lamp burners, $75 \mathrm{c}$ and 1.00 ; postage extra Buckeye Inc. Lamp Chimney, each .50; postpair .60 Buckeye Inc. Ad. Rod \& Set Screws .50; postpaid .60 Buckeye Egg Testers, each__-_.50; postpaid .60 Buckeye Brooder Thermometer, ea. 1.25; postpaic 1.35 Buckeye Brooder Wafers, each_-- .50; postpaid

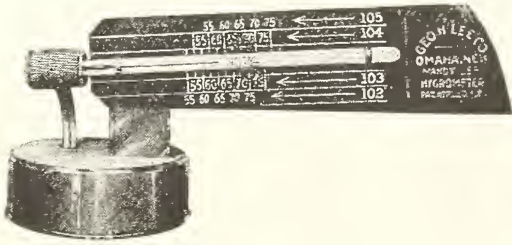

MANDY LEE HYGROMETER

Reigsters accurately the percentage of moisture it the egg chamber, and directions that go with it show absolutely what percentage of moisture is needed during each day of incubation and how the desired amount may be maintained, regardless of the humidity of the outer air. Can be used in any incubator. Price of the Mandy Lee Hygrometer, \$2.00; postpaid, \$2.10. Extra wicks, $10 \mathrm{c}$ each; 3 for $25 \mathrm{c}$.

\section{IMPROVED AUTOMATIC CHICK GREASER}

Saves the chicks from vermin. The chicken its own doctor. Will grease 100 chicks in a few minutes. Kills mites, fleas, lice and red bugs. The chicken, whils eating out of the pan, rubs against the wick, greasing itself; you don't catch them. Put melted lard in the tank and feed in the pan, set pan in the yard among the chicks and see how quick it works; the chicken and wick come together and the vermin are killed. No. 1 machine, for 50 chicks, $\$ 1.00$. Postpaid. \$1.15.

\section{INCUBATOR AND BROODER} THERMOMETERS

For use with any make of incubator.
Tycos 5774, standing kind, each Tycos 5774, standing kind, each $------75 \mathrm{c}$, postpaid
Tycos 5770 , hanging kind, each $-------75 \mathrm{c}$ postpaid Tycos 5792, brooder thermometer, each---60c, postpaid Cotton Lamp Wicks, all sizes, each 5c: doz.. $50 \mathrm{c}$ postpaid.

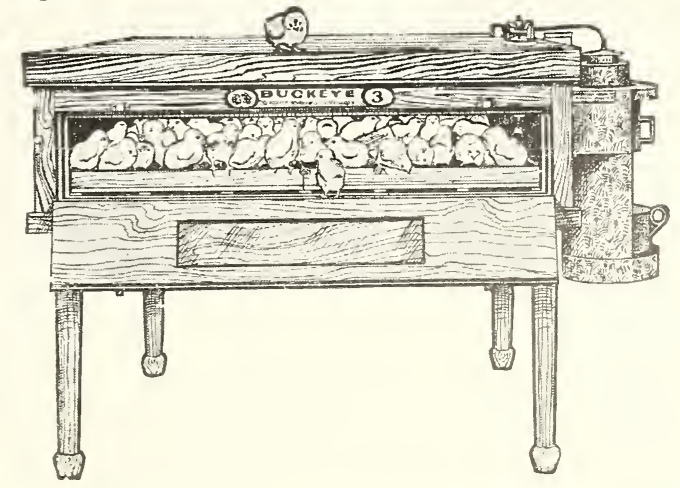




\section{POULTRY FEEDS}

\section{CHAMBERLAIN'S PERFECT CHICK FEED}

The original dry feed for baby chicks, made without any corn, avoids bowel trouble and many other diseases caused by improper feed. Contains all the meat, bone, charcoal, grit, oat meal, etc., necessary for the successful raising of baby chicks, thus making it unnecessary to feed them anything else. 5 lbs., 25c; postpaid, 亏 lbs., 40c.

CONKEY'S BUTTERMILK STARTING FOOD

The history of poultry keeping records no triumph such as this wonderful chick food has had. The rich, pure, buttermilk is mixed with a combination of clean, wholesome grains, balanced just right for the sensitive organs of the little chicks. The lactic acid keeps down yourself. By freight, $21 / 2$ lb., 25c; 5 lb., 40c; 10 lb., 70c. Postpaid, $2 \frac{1}{2} \mathrm{lb}$., 35c; $5 \mathrm{lb} ., 55 \mathrm{c} ; 10 \mathrm{lb} ., 95 \mathrm{c}$.

\section{POULTRY SCRATCH FEED}

This quality feed contains no shell or grit to make weight; try it, and you will use no other. Composed of choice grains, seeds and charcoal. A clean, bright, balanced ration for general use. As a scratch feed it is unequaled. Made without grit or shells. 7 lbs., 25c. Postpaid, 7 lbs., 40c.

\section{FINE CHICK FEED}

Composed of cracked grains, seeds and charcoal. Highly nutritious, easily digested and especially suited to the tender digestive organs of the little chicks. Made without grit. 6 lbs., 25c. Postpaid, 6 lbs., $40 \mathrm{c}$.

\section{COARSE CHICK FEED}

A developing food, composed of cracked grains and seed of the highest quality and especially adapted to the growing period, and when used insures a strong and rapid growth. This feed also contains charcoal. 6 lbs., 25c. Postpaid, 6 lbs., 40c.

\section{O. K. POULTRY LITTER}

A perfect scratching material. Superior to straw, alfalfa meal, etc. A deodorizer, absorbent, disinfectant and labor-saving litter. It absorbs all the moisture from droppings. Will last for several months in your brooder or poultry house. Lice will not live in it, and therefore makes a splendid material for nests, being soft and pliable and keeps out all insects. Try O. K. Litter once and you will never be without it. Price, 18 lbs., $\$ 1.00$; 50 lbs., $\$ 2.00$; bale, about 160 lbs., $\$ 5.50$, f. o. b., Memphis.

\section{GRANULATED BONE}

Granulated Bone is made from fresh, green bone, from which the moisture and grease have been taken, leaving nothing but the phosphates, lime and nitrogenous matter. These are the only food properties of bone, green or dry, so when you buy granulated bone you will get it without paying freight on moisture or grease. This preparation will keep in any climate, in any climate, in any kind of weather, if kept in a dry place. It is especially valuable as an eggshell producer. Promotes strong, healthy growth of the bones in young chickens. Prevents leg weakness. Mix a little in soft feed. Coarse, for hens, 3 lbs., 25c; 25 lbs., $\$ 1.50 ; 100$ lbs., $\$ 5.00$. Fine, for chicks, 3 lbs., $25 \mathrm{c} ; 25$ lbs., $\$ 1.50$; $100 \mathrm{lbs} ., \$ 5.00$. Postpaid, $3 \mathrm{lbs} ., 35 \mathrm{c}$.

\section{DRY MASH FEED}

This is the great egg producer. A mash feed prepared expressly for egg production, being very rich in egg-making elements. This mash is unsurpassed as a winter egg maker. It is the most wonderful feed in the world for making hens lay in cold weather. 5 lbs., 25c. Postpaid, 5 lbs., 40 c.

\section{CHARCOAL}

If you want healthy chickens, rugged-growing stock with bright healthy plumage, birds that will fatten easily and well, and entire freedom from sour crops and indigestion with laying stock, feed Charcoal. This is an easy hint to take, and the coal is low in price. The per hen cost is so low as to be almost ridiculous, and yet it is one of the simplest and best helps to success. Keep it before them all the time, and also feed in the mixed grain. Nothing equals it as a disease preventative. Made in 3 sizescoarse for hens; medium for pigeons; fine for baby chicks. Price, 2 lbs., 15c; 25 lbs., $\$ 1.50$; 50 lbs., $\$ 2.50$; 100 lbs., $\$ 4.50$. Postpaid, 2 lbs., for $25 \mathrm{c}$.

\section{GROUND OYSTER SHELLS}

Every poultryman realizes the importance of crushed oyster shells as an egg-shell maker, and promoter of good health. Every pound of oyster shells offered by us is especially prepared for feeding poultry. They are crushed and ground to the size which expert poultrymen agree to be the best. Use oyster shell freely. It is good for chickens, old or young. Coarse, for hens, $10 \mathrm{lbs} ., 25 \mathrm{c}$; $50 \mathrm{lbs} ., 75 \mathrm{c} ; 100 \mathrm{lbs}$, $\$ 1.25$. Fine, for chicks, 10 lbs., 25c; 50 lbs., $75 \mathrm{c} ; 100$ lbs., $\$ 1.25$. Postpaid, 10 lbs., 50c, not past 3 rd zone.

\section{GRIT FOR POULTRY}

Poultry Grit-Grit is as essential for poultry as food, as without it they cannot digest the food. Poultry will starve to death with full crop for not other reason than they have no teeth with which to grind the food into proper consistency. Grit should be fed in hopper's or boxes. Hen size, $10 \mathrm{lbs}$., 25c; 50 lbs., $75 \mathrm{c} ; 100$ lbs., $\$ 1.25$. Chick size, 10 lbs., 25c; 50 lbs., 75c; 100 lbs., $\$ 1.25$. Postpaid, $10 \mathrm{lbs}$., 50c, not past 3rd zone.

\section{ALFALFA CLOVER MEAL}

It is an acknowledged fact that green food is one of the most important foods necessary to heavy egg production. Among those who are unable to obtain a plentiful supply of green stuff, Alfalfa Meal should fill a long-felt want, it being an excellent substitution and a very nutritious food, which, when mixed with the mash, also affords bulk to concentrated foods. 50 lbs., $\$ 1.50 ; 100$ lbs., $\$ 2.50$.

\section{DARLING'S MEAT SCRAPS}

Darling's Meat Scraps-For success with poultry it is absolutely necessary to give them plenty of animal food in the winter, to take the place of insects, etc., which they get during the summer. Feed mixed with meal or bran, at the rate of $1 / 4 \mathrm{lb}$. beef scraps per day to a dozen hens. 3 lbs., 25c; 25 lbs., $\$ 1.50$; 50 lbs., \$2.85; 100 lbs., $\$ 5.50$. Postpaid, 3 lbs., 35c. 


\section{VICKSBURG SEED CO.'S PRICE LIST}

\section{JANUARY 1st, 1924}

\section{VICKSBURG, MISS.}

Prices quoted on this list are present values, subject to change without notice, net cash, and are F. O. B. Vicksburg, Miss., sacks included, purchaser paying all freight or express charges, and if to be sent by parcel post sufficient postage must be added to the following prices. If prices are lower, refund will be made; if higher we will advise.

\section{ARTICHOKES.}

Jerusalem (bu. 50 lbs.)

\section{BEANS. BUSH-Green Pod.}

$$
\text { (bu. } 60 \text { lbs.) }
$$

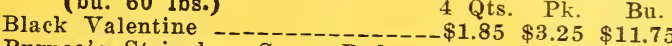

Burpee's Stringless Green Pod_--- $1.65 \quad 2.75 \quad 10.75$

Giant Stringless Green Pod_.....- $1.75 \quad 3.00 \quad 11.00$

Improved Extra Early Red

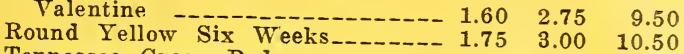

Tennessee Green Pod_..._..... $1.65 \quad 2.85 \quad 10.50$

BEANS, BUSH-Wax Pod.

$$
\text { (bu. } 60 \text { lbs.) }
$$

Prolific Black War

4 Qts. Pk. $\quad$ Bu.

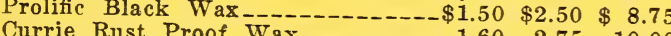

Davis White Kidney Wax

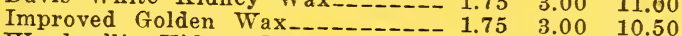

Wardwell's Kidney Wax_......- $1.75 \quad 3.00 \quad 11.75$

\section{BEANS, POLE OR RUNNING-}

(bu. 60 lbs.)

Kentucky Wonder

4 Qts. Pk. Bu.

White Creaseback

Red Speckled Cut Short_-- $1.75 \quad 3.00 \quad 10.50$

$\begin{array}{llll}\text { Scotia or Striped Creaseback } \ldots-\ldots-1.85 & 3.25 & 12.50\end{array}$

McCaslan Pole _..................25 2.25

BEANS, POLE IIMA-(bu. 60 lbs.) 4 Qts. Pk. Bu.

Carolina Sieve or Small Lima_... $\$ 2.00 \$ 3.75 \$ 12.50$

King of Garden _........... $2.00 \quad 3.50 \quad 13.00$

Large White Lima

Calico or Speckled

BEANS, BUSH LIMA-(bu. 60 lbs.) 4 Qts. Pk. Bu. Henderson's Bush

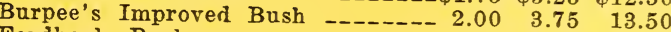

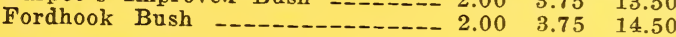

CORN, GARDEN

Extra Early Adams (bu, 56 lbs)

Golden Bantam (bu. 45 lbs.) _ $\$ .85 \$ 1.25 \$ 4.25$

Early Fordhook (bu. 45 lbs.)

Adams' Large Early (bu. 56 lbs.) _ $\quad .85 \quad 1.25 \quad 4.25$

Early Surprise (bu. 56 lbs.) _...

Country Gentleman (bu. 45 lbs.) -- $\quad .90 \quad 1.50 \quad 5.00$

Mammoth or Large Sugar (bu.

45 lbs.) _............ $90 \quad 1.50 \quad 5.00$

Stcwell's Evergreen (bu. $45 \mathrm{lbs}$ ) -- $\quad .90 \quad 1.50 \quad 500$

ONION SETS-(bu. $32 \mathrm{lbs}$ ) $\quad 4$ Qts. Pk. Bu.
Yellow Danvers

Dark Red Wethersfield _....... $.60 \quad .95 \$ 3.00$

White Silver Skin _........

Yellow Potato

White Multipliers -

SEED POTATOES-(bu. 60 lbs.) Pk. Bu. $21 / 2 \mathrm{Bu}$

Red Triumphs, Northern Grown _- $\$ .75 \quad \$ 2.00 \$ \frac{21 / 2}{8 u}$

Red Triumphs, Tennessee 2d crop-- Write for prices

Irish Cobbler _................... $75 \quad 2.00 \quad 4.50$

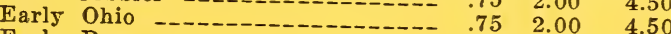

Early Rose -

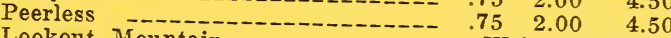

Lookout Mountain -

\section{SEED SWEET POTATOES-(bu. 45 lbs.)}

Nancy Hall

Porto Rica Yam... Write for prices

PEAS, GARDEN

American Wonder $4 \mathrm{Qts}$. Pk. Bu.

Alaska

Ameer, Large Alaska (bu. 60 lbs.) $\quad 1.60 \quad 2.75 \quad 10.00$

Ameer, Large Alaska (bu. $60 \mathrm{lbs}$ ) $\quad 1.75 \quad 3.00 \quad 11.00$

First and Best _-..-(bu. $60 \mathrm{lbs}$.) $\quad 1.75 \quad 3.00 \quad 11.00$

Gradus, or Prosperity (bu. 56 lbs.) $2.00 \quad 3.25 \quad 11.50$

Champion of England _(bu.56 lb.) $\quad \begin{array}{rrr}1.60 & 2.75 & 9.50\end{array}$
Large White Marrow-

fat - N (bu. $60 \mathrm{lbs}$ )

Telephone

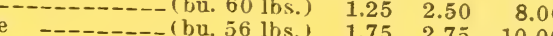

\begin{tabular}{llll} 
Laxatonian --.--- (bu. $56 \mathrm{lbs}$.) & 1.75 & 2.75 & 10.00 \\
\hline
\end{tabular}

Thomas Laxton -...-(bu. 56 lb.) $1.75 \quad 3.00 \quad 11.00$

SEED CORN-White-(bu. 56 lbs.) Pk. Bu. $21 / 2 \mathrm{Bu}$

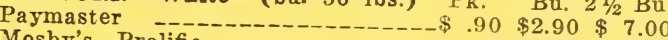

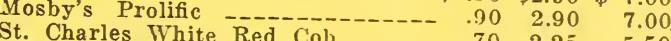

St. Charles White Red Cob__-_- $\quad .70 \quad 2.25 \quad 5.50$

Mexican June _........... $90 \quad 2.75 \quad 6.50$

Tait's White Dent

Champion White Pearl_.. $\quad .70 \quad 2.25 \quad 5.50$

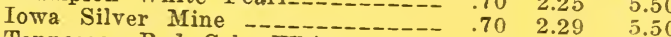

Tennessee Red Cob, White_._-_. $\quad .90 \quad 2.90 \quad 7.00$

Hickory King _..............

SEED CORN-Yellow-(bu. 56 lbs.) Pk. Bu. $2 \frac{1}{2} \mathrm{Bu}$

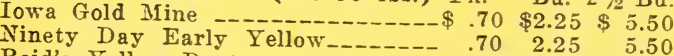

Reid's Yellow Dent _.....-..-..- $\quad .70 \quad 2.25 \quad 5.50$

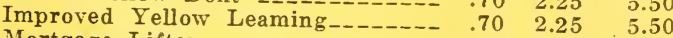

Mortgage Lifter _........... $1.00 \quad 3.00 \quad 7.00$

Tennessee Mammoth Yellow -.- $1.00 \quad 3.00 \quad 7.00$

ENSILAGE AND FODDER CORN(bu. 45 lbs.)

Eureka White Ensilage

Alfalfa. Dakota No. 12,

Pk. Bu. $100 \cdot \mathrm{lb}$

Fancy -- - (bu. $60 \mathrm{lbs}$ ) $\$ 4.25 \quad 16.50 \$ 26.50$

Alfalfa, Fancy Native (bu. 60 lbs.) $4.00 \quad 15.00 \quad 24.50$ Red Clover, Fancy

Ohio -

Mammoth or Sappling

Clover _........ (bu. 60 lbs.) $\quad 4.75 \quad 18.00 \quad 30.00$

Alsike Clover -...-(bu. 60 lb.) $\quad \begin{array}{llll}3.50 & 12.25 & 20.00\end{array}$

White Clover -..--(bu. 60 lbs.) $\quad 9.00 \quad 36.00 \quad 60.00$

Crimson Clover _...-(bu. 60 lbs.) $\quad 3.00 \quad 11.00 \quad 17.50$

apan Clover

$\begin{array}{llllll}\text { (Lespedeza Striata }) & \text { - }\left(\begin{array}{llll}25 & \mathrm{lbs} .\end{array}\right) & 1.50 & 5.00 & 20.00\end{array}$

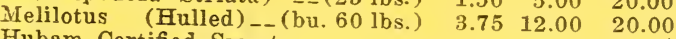
Hubam Certified Sweet

Clover _.......-(bu. $60 \mathrm{lbs}$ ) $7.50 \quad 25.00$

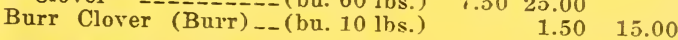

GRASS SEEDS

$10 \mathrm{lb} .50 \cdot \mathrm{lb} \cdot 100 \cdot \mathrm{lb}$

Sunny South Lawn Grass_..-_-_- $\$ 4.5020 .00 \$ 40.00$

Shady Spot Lawn Grass_._._-_.- $4.5020 .00 \quad 40.00$

Permanent Pasture Grass Mix-

$\begin{array}{ccccc}\text { ture } & -17.00 & 32.50\end{array}$

ture -......... (bu. 14 lbs.) $3.50 \quad 17.00 \quad 32.50$

Permanent Hog Pasture Mix.

ture _-.... (bu. 14 lbs.) $3.50 \quad 17.00 \quad 32.50$

$\begin{array}{lrrr}\text { Timothy and Alsike Mixture } \ldots . . .- & 2.50 & 8.50 & 16.00\end{array}$

Kentucky Blue Grass_(bu. 14 lbs.) $4.50 \quad 20.00 \quad 39.00$

English Blue or Meadow Fescue

Italian Rye Grass-- (bu. 14 lbs.) $3.00 \quad 11.00 \quad 20.00$

Italian Rye Grass_--- (bu. 14 lbs.) $2.25 \quad 9.50 \quad 18.00$

Perennial Rre Grass_-(bu. 14 lbs.) $2.25 \quad 9.50 \quad 18.00$

Johnson Grass _.....(bu. 25 lbs.) $2.00 \quad 8.00 \quad 18.00$

Orchard Grass --.--(bu. 14 lbs.) $3.00 \quad 12.00 \quad 25.00$

Bermuda Grass -

Red Top or Herds Grass, Fancy

$\begin{array}{lllll}\text { seed } & -12.00 & 23.50\end{array}$

Tall Meadow Oat Grass(bu. 14 lbs.) $3.75 \quad 16.00 \quad 30.00$

Timothy _.........(bu. 45 lbs.) $1.50 \quad 6.50 \quad 30.00$

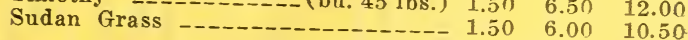

FIELD BEANS-(bu. 60 lbs.) $4 \mathrm{Qts}$. Pk. Bu.

$\begin{array}{llll}\text { Velvet Beans, Early Bird Speckled_\$ } \$ .50 & \$ .90 & \$ 2.85 & \\ \text { Velvet Beans, Bush } & .65 & 2.85 & \end{array}$

Velvet Beans, Bush__........ $\quad .65 \quad 1.00 \quad 3.50$

$\begin{array}{lllll}\text { Velvet Beans, Osceola_-_-_._- } & .65 & 1.00 & 3.50 \\ \text { Soy Beans, }\end{array}$

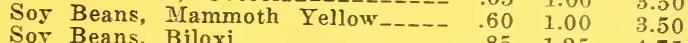

$\begin{array}{lrrr}\text { Soy Beans, Oo Too Tan_-_-_-_-- } & .85 & 1.25 & 4.75 \\ & 2.25 & 8.00\end{array}$

Soy Beans, Laredo_.......... $2.50 \quad 4.50 \quad 16.00$ 
COW PEAS-(bu. $60 \mathrm{lbs}$.)

Whippoorwill, or Speckled

Black -

Red Ripper

Clay

Mixed

(1)

New Fre

WHITE TABLE PEAS-

$$
\text { (bu. } 60 \mathrm{lbs} . \text { ) }
$$

California Large White Black-eyed 4 Qts. Pk. Bu.

White Brown-eyed

White Lady Peas

White Sugar Crowder.

Write for prices

Write for prices

Write for prices

\section{PEANUTS AND CHUFAS}

Pl. Bu. 100-1b:

Spanish Peanuts _-_- (bu. 22 lbs.) $\$ .75 \$ 2.75 \$ 12.50$

Tennessee Mammoth Long

Red Mamm

ginia $1.00 \quad 3.50 \quad 15.00$ Chufas (Earth Almonds)

$$
\text { (bu. } 44 \text { lbs.) } 2.00 \quad 6.50
$$

\section{MILIET SEED}

10-1b. $50-1 b .100-1 b$.

Tennessee Golden Millet

(bu. 50 lbs.) $\$ .75 \$ 3.00 \$ 6.00$

Western Golden Millet

(bu. 50 lb.) $\quad .60 \quad 2.50 \quad 5.00$ Japanese, or Barnyard Millet_-_- $\quad .75 \quad 3.50 \quad 6.00$ Pearl, or Cat Tail Millet____-_- $2.50 \quad 10.50 \quad 20.00$

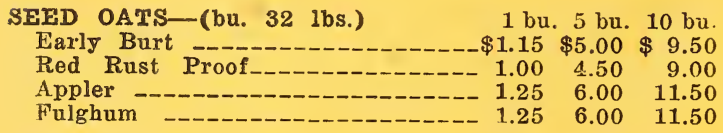

SORGHUM OR SUGAR CANE(bu. $50 \mathrm{lbs}$ )

10-1b, 50-1b, 100-1b

Texas-Seeded Ribbon Cane

$\$ 1.25 \$ 4.00 \$ 8.00$

Japanese Honey Syrup Cane--_-- $1.25 \quad 4.00 \quad 8.00$

Early Orange Sorghum______- $.85 \quad 2.50 \quad 4.50$

Early Amber Sorphum

Red Top Sorghum $1.00 \quad 3.00 \quad 5.50$

White Kaffir Corn_-

Red Kaffir Corn

Yellow Milo Maize____-_-_- $\quad .70 \quad 2.75 \quad 5.00$

$\begin{array}{lllll}\text { Feterita } & 70 & 2.85 & 5.50\end{array}$

Egyptian Wheat or Shallu_-

MISCELLANEOUS FARM SEEDS $1 \mathrm{lb}$. Pk. Bu.

Speltz or Emmer-_--(bu. 40 lbs.) $\$ .10 \$ .85 \$ 3.00$

Beardless Spring Barley

$\begin{array}{lllll}- & & & \end{array}$

Japanese Buckwheat (bu. 50 lbs.) $\quad .15 \quad 1.00 \quad 3.50$

Silver Hull Buckwheat. (bu. 50 lbs.) $.15 \quad 1.00 \quad 3.75$

Broom Corn, Improved Evergreen

(bu. $46 \mathrm{lbs}$.)

Broom Corn, Dwarf Oklahoma

(bu. 46 lbs.) $\quad .15 \quad 1.00 \quad 3.75$

1-lb. 10-lb. $50-1 \mathrm{~b}$.

Teosinte

$\$ .85 \$ 7.50$

Spring Vetch

Sand or Hairy Vetch

Sunflower, Russian

Rape, Divarf Essex

COTTON SEED-(bu. $30 \mathrm{lbs})$

Simpkins

1 bu. 5 bu. $10 \mathrm{bu}$.

Half and Half-_-

Wannamaker-Cleveland _-

Early Triumph Big Boll _._._- 2.50 $12.00 \quad \mathbf{2 2 . 5 0}$

King's Early Improved _-

Acala No. 5.

Express 350 -

Delphos 6162 -

Saulsbury Staple

\section{POULTRY FEEDS}

We can supply you with high grade poultry feeds, mashes, chick grain, starting feed, etc. Write for brands and prices

\section{VICKSBURG SEED CO. VICKSBURG, MISS.}




\section{FROST-PROOF CABBAGE PLANTS}

There are a number of islands on the Coast of Louisiana where the soil and climate conditions are just suited for growing tough, hardy cabbage plants during the Winter and early Spring. The plants Winter and early spring. The plants eight to ten weeks of age they are very tough and hardy, the buds are purple and the outer leaves a reddish brown. When in this condition they can be shipped to territory further north and be planted in the open ground a month to six weeks sooner than the home-grown hotbed or coldframe plants.

Plants usually withstand the cold winter, say at least six winters out of 8 in Texas, Louisiana, Mississippi and Alabama. In other territories. February and March are best months to plant. The word "frost-proof", does not mean "freeze-proof," However, you will be surprised at the amount of freezing weather the plants will stand. A temperature of 20 degrees above zero with sleet and snow seldom hurts them.

The top of the plant does not grow until your regular Spring weather opens up, but the roots planted, and just as soon as Spring weathplanted, and just as soon as Spring weathsimilates the fertilizer in the soil and the plants grow very fast, maturing headed cabbage two to three weeks sooner than rou can mature them from hotbed and cold frame plants.

To get the advantage of these frost-proof cabbage plants they must be planted a month or six weeks earlier than you would plant home-grown plants. We fill orders from Januars 15th to May 1st.

The plants when received will be somewhat wilted and have a hard stunted appearance, which will be disappointing to persons who have never used the plants be-

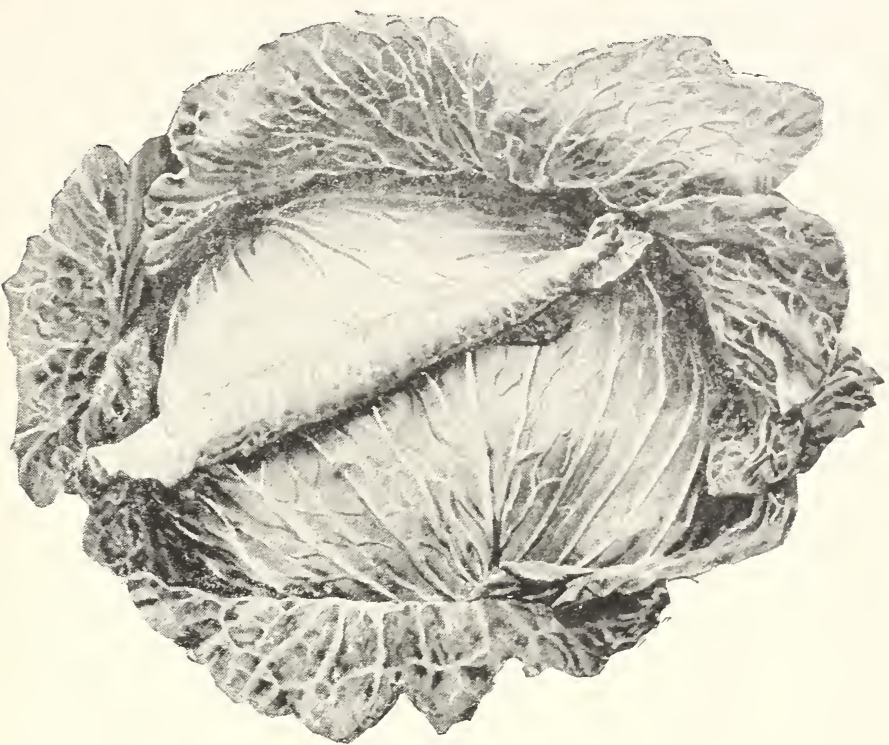

fore. Regardless of appearance, they will produce the crop results.

Will have the following varieties:

Early Jersey Wakefield Early Flat Dutch Charleston or Large Wakefield and Succession

Prices, by parcel post, 100 for 50c; 500 for $\$ 1.75$; 1000 for $\$ 3.00$. No orders filled for less than 100 piants of a variety. By express, not prepaid, 100 for $40 \mathrm{C}$; 500 for $\$ 1.25 ; 1000$ for $\$ 2.25$.

\section{VEGETABLE PLANTS}

\section{HOME-GROWN CABBAGE PLANTS}

These are ready about the first part of March; they should not be set out earlier, being tender they are not as hardy as the frost-proof kind.

We can furnish the following varieties: Jersey Wakefield, Early Flat Dutch, Charleston Wakefield, Succession.

Prices: Parcel post paid-100, 50c; 500, $\$ 1.75$ $1,000, \$ 3.00$. By Express, not prepaid-100, $40 \mathrm{c}$ $500, \$ 1.50 ; 1,000, \$ 2.75$.

\section{BEET PLANTS}

Ready about March 1st.

Varieties-Crosby's Egrptian and Crimson Globe.

Prices: Parcel post paid-100, 55c; 500, $\$ 2.00 ; 1000$ $\$ 3.35$. By Express, not prepaid-100, $40 \mathrm{c} ; 500, \$ 1,75$ $1,000, \$ 3.00$.

\section{CAULIFLOWER PLANTS}

Ready March 1 st.

Varieties-Early Snowball and Dry Weather.

Prices: By parcel post-Doz., 25c; $50,90 \mathrm{c} ; 100$, $\$ 1.50$. By Express, not prepaid-Doz., 20c; 50, 75c; $100, \$ 1.25$

\section{CELERY PLANTS}

Ready April 1st.

Varieties-Golden Self-Blanching and Henderson's White Plume.

Prices: By parcel post-Doz., 25c; 50, 45c; 100 , 75c. By Express, not prepaid-Doz., 20c; $50,35 \mathrm{c}$ $100,60 \mathrm{c} ; 500, \$ 2.00$.

\section{EGG PANTS}

These are ready about April 20th.

Varieties-Black Beauty, N. Y. Improved Purple.

Prices: Parcel post paid-Doz., 35c;50, 90c; 100 $\$ 1.50$. By Express, not prepaid-Doz., 25c; $50,75 \mathrm{c}$ $100, \$ 1.25$.

\section{LETTUCE PLANTS}

Ready March 1st.

Varieties-Big Boston, New York or TVonderful.

Prices: Parcel post paid-50, 35c; 100, 55c; 500 $\$ 2.00$. By Express, not prepaid-50, 25c; 100, $45 \mathrm{c}$ $500, \$ 1.75 ; 1,000, \$ 3.00$.

\section{PEPPER PLANTS}

Ready April 15th.

Varieties-Chinese Giant, Ruby King, Long Cayenne.

Prices: Parcel Post paid-Doz., 35c; 50, 90c: 100 $\$ 1.50$. By Express, not prepaid-Doz., $25 \mathrm{c} ; 50,75 \mathrm{c}$ $100, \$ 1.25$.

\section{TOMATO PLANTS}

These are ready about the 20 th of March. Our stock is raised from the very best quality of seed and will give perfect satisfaction.

Varieties-Gulf State Market, Ponderosa, Norton Wilt Resistant, Early Detroit, Globe, Stone.

Prices Hot Bed or Seedling Stock: Parcel Post paid -Doz., 25c; 100, 75c; 500, \$3.50. By express, not prepaid-Doz., 15c; 100,60c; $500, \$ 2.00$

Prices Transplanted Stock: Parcel Post paid-Doz. $35 \mathrm{c} ; 50,90 \mathrm{c} ; 100, \$ 1.50$. By Express, not prepaidDoz., $25 \mathrm{c} ; 50,75 \mathrm{c} ; 100, \$ 1.25 ; 1,000, \$ 10.00$.

\section{SWEET POTATO SLIPS}

Varieties-Certified Nancy Hall and Porto Rico.

Prices Certified Slips: 500, $\$ 1.50 ; 1,000, \$ 2.75$. No order filled for less than 500 certified plants. All shipments will be made from our nearest growers. By express only in state of Mississippi. Into other states if wanted by parcel post, prices: 100 for $50 \mathrm{c}$; 500 for $\$ 1.75$; 1000 for $\$ 3.00$, postpaid.

THE BENTON REVIEW SHOP, FOWLER, IND. 


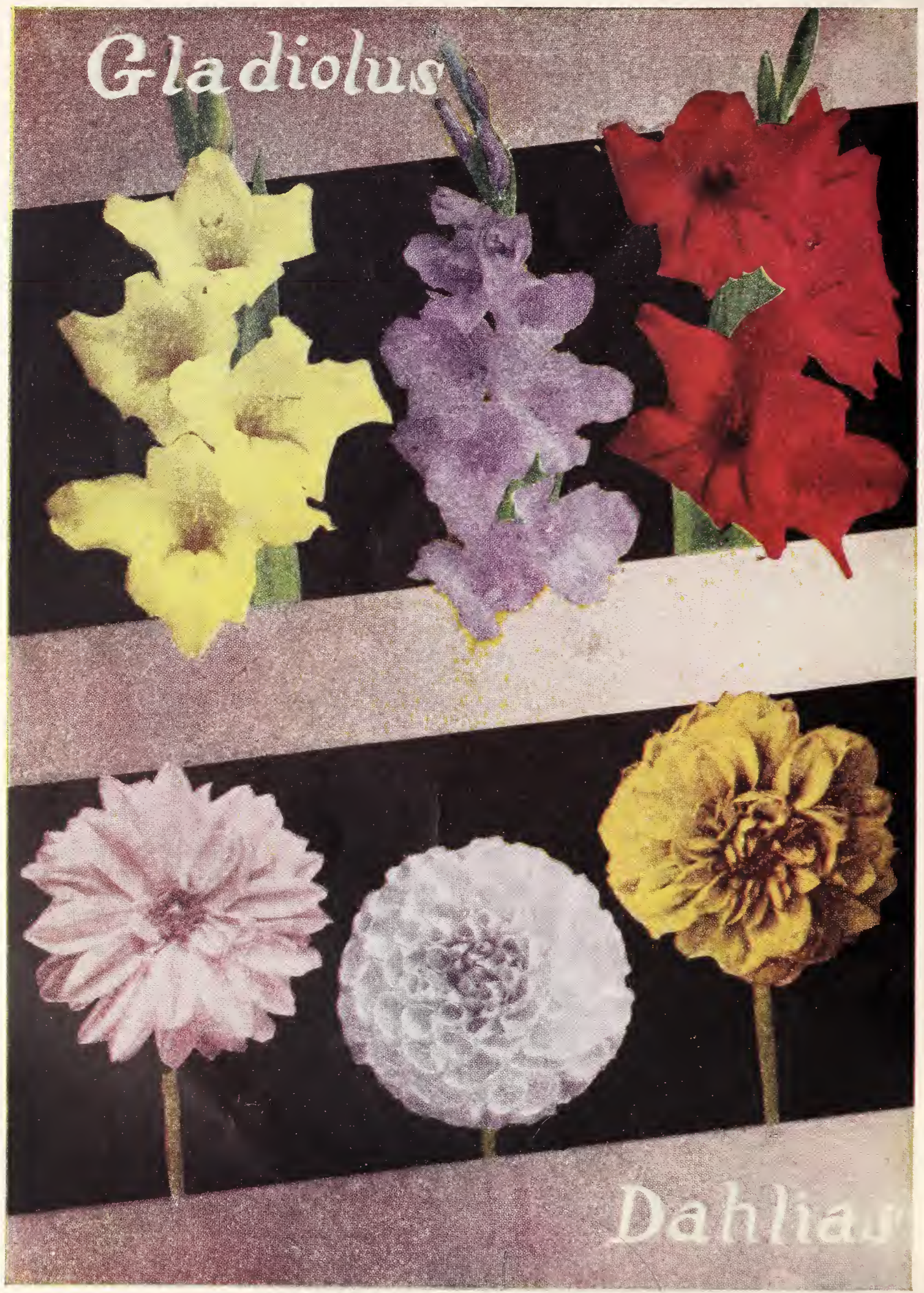

